\title{
BIOSÍNTESIS, SEÑALIZACIÓN Y MODO DE ACCIÓN DEL ÓXIDO NÍTRICO EN Arabidopsis thaliana
}

Jorge Lozano Juste

TESIS DOCTORAL

Director:

Dr. José León Ramos 



\title{
BIOSÍNTESIS, SEÑALIZACIÓN Y MODO DE ACCIÓN DEL ÓXIDO NÍTRICO EN Arabidopsis thaliana
}

\author{
Memoria presentada por \\ JORGE LOZANO JUSTE \\ para optar al grado de \\ DOCTOR EN BIOTECNOLOGÍA por la UPV \\ Director \\ Dr. José León Ramos
}

UNIVERSIDAD POLITÉCNICA DE VALENCIA

Departamento de Biotecnología

Valencia, 2011 

El Dr. José León Ramos, Investigador científico del Consejo Superior de Investigaciones Científicas,

\section{CERTIFICA:}

Que la presente memoria titulada "BIOSÍNTESIS, SEÑALIZACIÓN Y MODO DE ACCIÓN DEL ÓXIDO NÍTRICO EN Arabidopsis thaliana" ha sido realizada por Jorge Lozano Juste bajo mi dirección y constituye su Memoria de Tesis para optar al grado de Doctor en Biotecnología.

Para que así conste a todos los efectos oportunos, firma el presente certificado en Valencia, a 18 de Mayo de 2011.

Dr. José León Ramos 

A mis padres 



\section{AGRADECIMIENTOS}

Primero, quiero mostrarle mi agradecimiento a mi jefe, Pepe León, por haber accedido a que empezara la tesis en su laboratorio, por haber tratado siempre de buscarme financiación y por haberme enseñado a ser metódico y crítico con mi trabajo. Si bien nunca conseguí que me mandara a realizar ninguna estancia fuera del instituto (y no será por que no lo intenté) me ha ayudado muchísimo a involucrarme en mi trabajo y a exprimir todos los recursos de los que disponía dentro y fuera del IBMCP. La verdad es que en su labo he aprendido muchísimo y por eso siempre le estaré agradecido. Siempre estaré agradecido también a toda la gente que ha pasado por el labo, Cris, Mari Cruz, Silbia, Curro, Noe, Rosa, Ricardo, Laura, Esme, Esther, Conso y Alberto por todo lo que me han enseñado y por todas las críticas y discusiones sobre el trabajo que café a café y cigarro a cigarro, tanto han tenido que ver con que al final tú tengas esta tesis entre las manos. También quiero agradecerles el que en el labo siempre haya habido mucha ayuda y apoyo entre nosotros generando asi muy buen ambiente dentro del labo que también lo tenemos fuera en esas cervecitas que nos echamos de vez en cuando. Ha sido un lujo conoceros. Quiero hacer una mención especial a Rosa, Roseta, mi compañera en el labo durante muchos años. De ti he aprendido muchísimo Roseta, lo más importante, a creer en mi y a poder resolver problemas de manera autodidacta. La verdad es que eres una científica de pies a cabeza y te he echado mucho de menos estos últimos años. Por suerte, he estado muy bien acompañado en el labo y recordaré siempre las tardes a última hora con Ricardo y Laura empezando experimentos imposibles a las 8 de la tarde y partiéndonos de risa cuando la cabeza ya no daba para más. Gracias a vosotros estos años han sido geniales y no solo me habéis aportado mucha motivación y nuevas ideas sino que con los desayunos y las partidas de squash me habéis ayudado a no volverme del todo loco estos meses tan difíciles. Habéis sido un gran apoyo para mi, tanto en lo personal como en lo profesional, gracias!

Agradezco también a todos los que me habéis ayudado directamente en la realización de la tesis pasándome protocolos, semillas, reactivos, oligos, ... o dedicándome unos minutos para encontrar la mejor manera de hacer los experimentos. Entre estos, tengo mucho que agradecer a la gente del laboratorio de Alabadí y Blázquez (Alabadí, Blázquez, Eugenio, Paco, Javi, Vero, Nora, Berta, Iva y Antonella) porque siempre me han cedido muy amablemente todo lo que les he pedido, que ha sido mucho. En especial a Javi y a Vero que me enseñaron como hacer los experimentos de fotomorfogénesis, el uso del confocal para detectar la señal de proteínas casi invisibles, por pasarme semillas de numerosos y valiosos mutantes, proponerme nuevos experimentos y un sin fin de cosas más. Sin vuestra ayuda, siempre desinteresada, no hubiera podido terminar esa parte de la tesis. A los dos, muchísimas gracias. Estoy en deuda con vosotros. Quiero agradecer también a la gente del labo de Pedro Rodríguez (Silvia, Ángela, Américo, Julia, Regina, Lesia, Miguel y Pedro) el haberme ayudado con la parte del ABA, y por presentarme al que dentro de poquito será mi nuevo jefe .También estoy en deuda con Rafa, por haberme enseñado a manejar esos programas de análisis de estructura de proteínas que han hecho que el trabajo mejore muchísimo. Además, tengo que agradecerle también el haberme abierto los ojos a lo importante de la biología estructural, que ha motivado en gran parte la elección de mi postdoc. Es curioso porque Rafa, junto con otro amigo, Sergio, fueron los que me explicaron durante la carrera la posibilidad de colaborar en departamentos siendo responsables de mi primera incursión en un laboratorio de la universidad donde empecé a interesarme en la biología molecular y donde decidí finalmente empezar el doctorado. Gracias a los dos!

Tengo que agradecer también a los laboratorios que me han cedido sus materiales de manera desinteresada. Muchas gracias a Akira Nagatani, Dorothee Staiger, Cecilia Gotor, Rüdiger Hell, Dominique Rumeau, Renate Scheibe, Joe Ogas y Mariam Sahrawy por los anticuerpos. A David Alabadí, Cristina Martínez, Pablo Leivar, Vicente Rubio, Miguel Ángel Pérez, Pedro Rodríguez, Peter Quail, Nigel Crawford, ZhenMing Pei, Mary-Paz González, Nacho Rubio, Joseph Polacco, Chris Todd, Xin-Wang Deng, Tai-Ping Sun, Christian Fankhauser, Giltsu Choi y Steve Thomas por las semillas. A David Dixon por el clon de la Metionina Sintasa 1 y a Valerie Gaudin por el plásmido pRESC38. A Carlos Mesejo y Manuel Agustí por haberme enseñado y dejado utilizar su equipo psicrométrico sin pedir nada a cambio y a más de medio IBMCP por haberme dejado utilizar algo de su labo. Si es que ya lo dice el refrán: triste es pedir pero más triste es robar...

Pero por supuesto no todo ha sido trabajo y he tenido mucha suerte de haber estado rodeado de gente impresionante, tanto dentro, como fuera del instituto. Una de las primeras personas a las que le tengo mucho que agradecer es a Emilio, compañero en el labo de fisio vegetal de la Universidad de Valencia, de los primero años de tesis en el IBMCP y buen amigo donde los haya. Muchas gracias por haber estado siempre ahi!! También recordare siempre, el tandem del CIPF, Rafa, Imelda y Sergio, y las cervecitas en el Magic los primeros años de tesis. A estas tres personas les debo mucho y les agradezco su amistad, sus críticas y sus consejos. Más tarde apareció gente estupenda a los que les tengo muchísimo aprecio y a los que echare mucho de menos. Gracias a Maria Ángeles (lo siento, no me sale poner Marian), Javi, Alex, Peter, Ricardo, 
Silvia y Teresa por ser como sois,.... unos craks!! También quiero darle las gracias a Mary, una persona muy especial de la que he aprendido muchísimo. Gracias por ser la persona más generosa que he conocido nunca, por todos tus consejos y todas tus criticas y por haber compartido estos años conmigo. Gracias por haberme dado tanto. Gracias también a los amigos de siempre de Alcalá (Toni, Juan, Rubén, Cote, Ximo, Sergio, Javi, Juanjo y Enrique) y de Monzón (Javi, Sergio, Borja, Jorge y David) por haber intentado entender lo que hago y por preocuparos de que me vaya bien. Ya para terminar quiero darle las gracias a toda la gente que se ha preocupado por mi y por mi trabajo todos estos años y que por no enrollarme todavía más no voy a incluir aquí.

Por último, quisiera dejar aquí plasmada mi admiración por mis padres, Salvador y Conchita, por haber dedicado la mayor parte de sus vidas a sus hijos y ser pilar fundamental de toda mi vida. Quisiera transmitirles mi agradecimiento por todo su esfuerzo, tanto personal como económico, por haberme animado siempre a elegir mi propio camino, por haberme enseñado lo importante de disfrutar de mi trabajo y por apoyarme $100 \%$ en esta decisión mía de irme ahora tan lejos a pesar de que les duela mucho. Como no, también tengo que agradecer al resto de mi familia, en especial a mis hermanos, Sergio y Begoña, por haber sido y ser mis mejores amigos y por tratar siempre de protegerme y aconsejarme. También quiero agradecerle a mi tía, Rogelia, su generosidad y determinación y el sin fin de consejos que una persona con toda su trayectoria me ha dado en esos inolvidables viajes en coche desde Valencia a Monzón. Gracias también a Begoña y Miguel Ángel por habernos regalado a Ona, ese pequeño tesoro que hace que me sienta muy feliz. Es remarcable el esfuerzo que habéis hecho todos para tratar de entender siempre lo que hago en el laboratorio y el funcionamiento del mediocre sistema científico español haciendo incluso que en las comidas se puedan escuchar palabras como postdoc, Arabidopsis, óxido nítrico, mutante o western-blot. Muchísimas gracias a todos, os echare mucho de menos! 


\section{RESUMEN}

El óxido nítrico (NO) es una molécula gaseosa, muy reactiva, que ha ganado un creciente interés en los últimos años debido a su reconocido papel en señalización. Sin embargo, tanto su biosíntesis como su señalización o su modo de acción siguen siendo, en gran medida, desconocidas, lo que limita el avance del conocimiento de las bases moleculares de su función en plantas. En la presente tesis, hemos identificado las principales rutas enzimáticas de biosíntesis de NO en la planta modelo Arabidopsis thaliana mediante una aproximación genética. En un segundo paso, hemos utilizado los mutantes generados para establecer el papel del NO, y de cada una de sus rutas de biosíntesis, en diferentes procesos de desarrollo y de respuesta a estrés. Así, hemos descrito el papel negativo del NO en la sensibilidad al ácido abscísico en la regulación de la dormición y la germinación de las semillas, el establecimiento de plántula y el cierre estomático. Por otro lado, hemos definido el mecanismo molecular por el que el NO promueve la fotomorfogénesis. Brevemente, la producción de NO tras la transición de oscuridad a luz regula la expresión de genes clave de la fotomorfogénesis, como SLY1 y los factores de transcripción de tipo $P I F$, lo que promueve la des-etiolación que se concreta en una inhibición de la elongación del hipocotilo en condiciones de iluminación. Finalmente, para avanzar en el conocimiento sobre el modo de acción del NO, hemos caracterizado una de las modificaciones post-traduccionales mediadas por NO mediante el desarrollo de un método proteómico que nos permite enriquecer e identificar proteínas nitradas en residuos de tirosina. El trabajo desarrollado en esta tesis doctoral ha ayudado a avanzar en el conocimiento de los mecanismos moleculares por los que el NO regula algunos procesos fisiológicos en Arabidopsis thaliana y ha abierto numerosas puertas para el posterior análisis de muchos otros. 



\section{RESUM}

L'òxid nítric (NO) és una molècula gasosa, molt reactiva, que ha guanyat un creixent interès en els últims anys a causa del seu reconegut paper en senyalització. No obstant això, tant el seu biosíntesi com la seua senyalització o la seua manera d'acció segueixen sent, en gran mesura, desconegudes, la qual cosa limita l'avanç del coneixement de les bases moleculars de la seva funció en plantes. En la present tesi, hem identificat les principals rutes enzimàtiques de biosíntesi de NO en la planta model Arabidopsis thaliana mitjançant una aproximació genètica. En un segon pas, hem utilitzat els mutants generats per establir el paper del NO, i de cadascuna de les seves rutes de biosíntesi, en diferents processos de desenvolupament i de resposta a estrès. Així, hem descrit el paper negatiu del NO en la sensibilitat a l'àcid abscísic en la regulació de la dormició i la germinació de les llavors, l'establiment de plàntula i el tancament estomàtic. D'altra banda, hem definit el mecanisme molecular pel qual el NO promou la fotomorfogènesi. Breument, la producció de NO després de la transició de foscor a llum regula l'expressió de gens clau de la fotomorfogènesi, com SLY1 i els factors de transcripció de tipus PIF, la qual cosa promou la desetiolació que es concreta en una inhibició de l'elongació del hipocòtil en condicions d'il·luminació. Finalment, per avançar en el coneixement sobre la manera d'acció del NO, hem caracteritzat una de les modificacions post-traduccionals intervingudes per NO mitjançant el desenvolupament d'un mètode proteòmic que ens permet enriquir i identificar proteïnes nitrades en residus de tirosina. El treball desenvolupat en aquesta tesi doctoral ha ajudat a avançar en el coneixement dels mecanismes moleculars pels quals el NO regula alguns processos fisiològics en Arabidopsis thaliana i ha obert nombroses portes per a la posterior anàlisi de molts uns altres. 



\begin{abstract}
Nitric oxide (NO) is a very reactive gaseous molecule that has gained an increasing interest lately due to its well known signaling role. However, its biosynthesis, signaling and mode of action are still largely unknown, thus limiting our knowledge about the molecular basis of NO function in plants. In this Thesis, we have identified, by a genetic approach, the main NO biosynthetic pathways in the model plant Arabidopsis thaliana. Next, we have used the NO deficient mutants we have generated to characterize NO function in developmental and stressrelated responses. We have characterized a negative role of NO in ABA sensitivity and further regulation of seed dormancy and germination, seedling establishment and stomata closure. On the other hand, we have also defined the molecular mechanism underlying the positive regulation exerted by NO on photomorphogenesis. Briefly, the production of NO upon darkness to light transition modulates the expression of key photomorphogenesis-related genes such as SLY1 and $P I F \mathrm{~s}$, thus ensuring de-etiolation under light conditions. Finally, to gain further insight on the regulatory mode of action of $\mathrm{NO}$, we have optimized a proteomic methodology to characterize a NO-based post-translational modification by nitration of tyrosine residues that help in identifying target proteins of direct NO action. This work has allowed to improve our knowledge on NO regulation of different physiological processes in Arabidopsis and has opened many others for further analysis.
\end{abstract}



Introducción …………………………………………………………….... Pág. 1

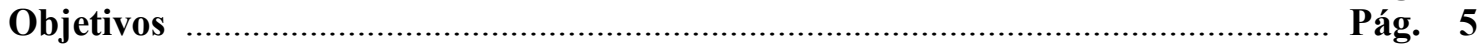

Capítulo 1. Biosíntesis de óxido nítrico (NO) …………………………………….... Pág. 7

Introducción .................................................................................... Pág. 8

Mecanismos no enzimáticos de producción de NO …………………..... Pág. 8

Mecanismos enzimáticos de producción de NO ...................................... Pág. 8

Ruta dependiente de arginina ............................................... Pág. 9

Rutas dependientes de nitrito ............................................. Pág. 11

Metabolismo del NO ……………………………………………....... Pág. 13

Resultados ………………………………………………………….... Pág. 15

Caracterización de mutantes en las principales vías de biosíntesis de $\mathrm{NO}$................................................................ Pág. 15

Producción de NO en los diferentes mutantes ........................................... Pág. 17

Obtención y caracterización del triple mutante nialnia2noal-2 ……………………………………………..... Pág. 19

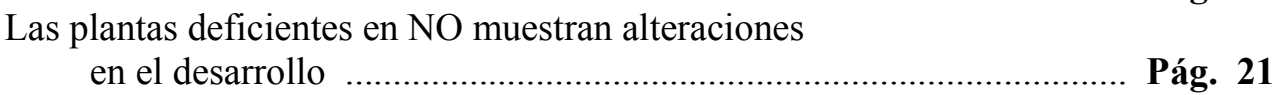

Discusión ……………………………………………………………..... Pág. 23

Capítulo 2. Interacción del NO y el ABA en procesos de desarrollo

y respuesta a estrés ……………………………………………………………... Pág. 27

Introducción ...................................................................................... Pág. 28

Interacción entre el $\mathrm{NO}$ y el $\mathrm{ABA}$ en procesos de desarrollo ………………………………………………..... Pág. 28

Interacción entre el ABA y el NO en la regulación del cierre estomático …………………………………………………... Pág. 31

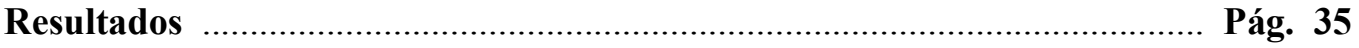

La producción de NO activada por ABA está comprometida en los mutantes NO deficientes ................................ Pág. 35

Interacción entre el $\mathrm{NO}$ y el $\mathrm{ABA}$ en el control de la dormición, germinación y el establecimiento de plántula ................. Pág. 36

Análisis de la expresión de genes de respuesta a ABA en los mutantes deficientes en NO ....................................... Pág. 40

La deficiencia en NO confiere resistencia a la



Discusión …………………………………………………………..... Pág. 44

Capítulo 3. Interacción NO-Giberelinas en el desarrollo regulado por luz ............ Pág. 49

Introducción ………………………………………………………... Pág. 50

Resultados ……………………………………………………….... Pág. 59

El mutante deficiente en NO nia 1,2noal-2,

presenta hipocotilos largos en luz

Pág. 59

El NO reduce la expresión de los genes $P I F \mathrm{~s}$ y provoca la acumulación de proteínas DELLA para regular

el tamaño del hipocotilo

Pág. 62

El NO provoca la acumulación de DELLAs mediante

la represión de $S L Y 1$

Pág. 69

La producción de NO responde a transiciones oscuridad-luz

y es regulada negativamente por GAs

Discusión

Pág. 74

Pág. 81

Pág. 82

Introducción

Pág. 83 
Nitración de tirosinas (Y-nitración) ……………………………….......... Pág. 84

Nitración de proteínas en plantas

Resultados Pág. 89

Detección y purificación de proteínas nitradas in vivo en Arabidopsis

Identificación de proteínas potencialmente nitradas

El análisis de ontología génica apunta a enzimas del

metabolismo primario y proteínas estructurales

del citoesqueleto como dianas generales de nitración en Arabidopsis

Pág.104

Identificación del sitio de nitración de la Metionina Sintasa 1 
Fig.1. Esquema mostrando el papel integrador del NO en la señalización de las diferentes hormonas Pág. 4

Fig.2. Síntesis de NO en plantas Pág. 14

Fig.3. Esquema representando los diferentes mutantes

(lineas de inserción de T-DNA) caracterizadas en este trabajo …….......................... Pág. 16

Fig.4. Identificación de mutantes nulos

Fig.5. Determinación de la acumulación de NO en las raíces de los diferentes mutantes

Pág. 18

Fig.6. Generación y genotipado del triple mutante nia1 nia2noa1-2

Pág. 19

Fig.7. Análisis de la expresión de AtNOA1, NIA1/NR1, NIA2/NR2,

XOR1 y XOR2 en los diferentes mutantes

Pág. 19

Fig.8. Producción de NO tras diferentes tratamientos o en los diferentes fondos genéticos deficientes en NO

Pág. 20

Fig.9. Diferentes fenotipos de los mutantes NO deficientes

Pág. 22

Fig.10. Complementación de alguno de los defectos en el desarrollo de los

mutantes deficientes en NO mediante la aplicación de NO exógeno

Pág. 23

Fig.11. Producción de NO en raíces de los diferentes mutantes deficientes

en NO tras la aplicación de ABA

Pág. 36

Fig.12. Los mutantes deficientes en la producción de NO son

hipersensibles a ABA

Pág. 37

Fig.13. Los mutantes deficientes en la producción de NO son

hipersensibles a ABA en germinación

Pág. 38

Fig.14. El contenido en sacarosa no afecta la sensibilidad a ABA de

los mutantes deficientes en la producción de NO

Pág. 39

Fig.15. Resistencia al déficit hídrico de los mutantes deficientes en NO

Pág. 41

Fig.16. El mutante nia1,2noa1-2 muestra una apertura estomática reducida

Pág. 43

Fig.17. Conductancia estomática, potencial hídrico (LWP) y pérdida

de peso de plantas silvestres y nia1,2noa1-2 tras diferentes periodos de sequia ........ Pág. 44

Fig.18. Acumulación de NO en células de guarda ..................................................... Pág. 46

Fig.19. La deficiencia en NO resulta en una sensibilidad incrementada

a ABA durante el desarrollo

Pág. 48

Fig.20. Esquema representando la percepción de las giberelinas

por su receptor y su interacción con otros componentes en la regulación

del proceso de des-etiolación

Pág. 56

Fig.21. Longitud del hipocotilo y la raíz en las plantas deficientes en NO

bajo diferentes condiciones

Pág. 60

Fig.22. Longitud del hipocotilo en función del tiempo y de la intensidad

de luz en los diferentes mutantes deficientes en NO

Pág. 61

Fig.23. Niveles de la proteína PHYB en diferentes mutantes y

comportamiento del mutante phyB en respuesta a NO

Pág. 63

Fig.24. Conexión funcional entre el NO, las giberelinas y los PIF

Pág. 65

Fig.25. Efecto del NO en la acumulación de las proteínas DELLA

Pág. 67

Fig.26. Efecto del NO en la elongación del hipocotilo y el contenido

en proteínas DELLA en luz roja

Pág. 70

Fig.27. Efecto del NO sobre los transcritos de los genes que codifican

las proteínas DELLA

Pág. 71

Fig.28. Efecto del NO sobre los transcritos de genes de la biosíntesis

y degradación de giberelinas

Pág. 71

Fig.29. Conexión funcional entre el NO y los componentes de la señalización

de las giberelinas GID1 y SLY1

Pág. 72 
Fig.30. Niveles de NO en los hipocotilos de diferentes genotipos en condiciones de oscuridad y tras la transferencia a la luz Pág. 73

Fig.31. Esquema integrando las funciones antagonistas del NO y las GAs en el control de la fotomorfogénesis a trvés del balance entre DELLAs y los PIFs ... Pág. 78 Fig.S1. Experimentos correspondientes a las figuras 21, 24, 26 y 29 realizadas en oscuridad Pág. 79

Fig.32. Diagrama representando la posición de la nitración en el anillo aromático de la tirosina Pág. 85

Fig.33. utas de nitración dependientes de peroxinitrito (ONOO') Pág. 86

Fig.34. Detección e inmunoprecipitación de proteínas nitradas en Arabidopsis

Fig.35. Detección de superóxido y NO en raíces de plántulas silvestres crecidas en condiciones estándar Pág. 89

Fig.36. La producción de NO inducida por el SA se acompaña de un cambio en el patrón de proteínas nitradas Pág. 90

Fig.37. Validación de la identificación proteómica Pág. 91

Fig.38. Efecto de la nitración de GAPDH Pág. 98

Fig.39. Identificación del sitio de nitración de la Metionina Sintasa 1 de Arabidopsis

Fig.40. El alineamiento estructural de los modelos de la GAPDH de Rata y Arabidopsis muestra una clara consevación Pág. 106 Fig.S2. Los potenciales sitios de nitración de GAPDH, Serina Hidroximetiltranferasa, Transcetolasa, Rubisco (subunidad grande) y Rubisco activasa están conservados en plantas y otros organismos Pág. 114 Fig.S3. Análisis del grado de conservación y de la estructura de las Metioninas Sintasas 
Índice de tablas

Tabla I. Efecto del tratamiento con sal o manitol en la germinación de semillas silvestres y de mutantes deficientes en NO Pág. 39

Tabla II. Niveles de expresión de genes de respuesta a ABA en plántulas de los mutantes deficientes en NO

Pág. 40

Tabla III. Análisis comparativo de los genotipos de los mutantes

phyB y nia1,2noal-2

Pág. 63

Tabla IV. Proteínas inmunoprecipitadas con anticuerpos anti-3-nitro-Y

e identificadas en plántulas de Arabidopsis thaliana mediante LC-MS/MS

Pág. 92

Tabla V. Proteínas putativamente nitradas identificadas por MALDI-TOF

Pág. 99

Tabla VI. Putativos péptidos nitrados identificados por MALDI-TOF a partir de proteínas separadas mediante 2-DE

Pág. 101

Tabla VII. Características estructurales de las potenciales Y dianas de

nitración en las proteínas identificadas por MALDI-TOF

Pág. 102

Tabla VIII. Enriquecimiento en categorias de Ontología Génica (GO)

entre las proteínas nitradas

Pág. 105

Tabla S1. Proteínas identificadas como putativamente nitradas en Arabidopsis

y los correspondientes homólogos funcionales identificados como nitrados

en otros sistémas diferentes a las plantas

Pág. 113

Tabla M1. Anticuerpos utilizados en este trabajo

Pág. 136

Tabla M2. Oligonucleótidos utilizados en este trabajo

Pág. 137 



\section{Introducción}

Uno de los pilares fundamentales para la aparición de vida en la superficie de la Tierra es la existencia de los organismos fotosintéticos capaces de producir y mantener una atmósfera rica en oxígeno. Hace unos 3000 millones de años, las plantas iniciaron el camino de la colonización del medio terrestre, y su aparición hizo posible el desarrollo de todas las formas de vida terrestre que hoy conocemos. Así, se hace imprescindible estudiar el funcionamiento de estos organismos fotosintéticos, que son, al menos en parte, responsables de la vida animal en la Tierra.

Existen numerosas diferencias entre los reinos animal y vegetal. A nivel celular, la diferencia más importante es que las plantas, a diferencia de los animales, presentan un orgánulo denominado cloroplasto (Strittmatter et al., 2010). En el interior de este orgánulo, se sintetiza y acumula clorofila, un pigmento con unas propiedades únicas que permite a la célula vegetal obtener energía de una fuente inagotable como es la luz solar, lo que supone una ventaja adaptativa frente a las células animales. Además, a diferencia de los animales, capaces de cambiar su localización en busca de un ambiente más favorable, las plantas son organismos sésiles que han evolucionado estableciendo un gran conjunto de respuestas adaptativas que los hacen extremadamente plásticos (Nicotra et al., 2010).

Esta plasticidad característica de las plantas obedece a una serie de mecanismos moleculares que hacen que estas respuestas adaptativas funcionen correctamente (Trewavas 2009). Uno de los pilares fundamentales de esta regulación es la función que ejercen determinadas moléculas, denominadas hormonas vegetales o fitohormonas, que gobiernan el resto de respuestas (Santner et al., 2009). Existen cinco hormonas consideradas clásicas: auxinas, citoquininas, giberelinas, etileno y ácido abscísico. Cada una de ellas tiene un papel crucial en procesos esenciales para el correcto desarrollo de una planta, tales como: el establecimiento de la polaridad en el embrión (auxinas), la promoción de la división celular (citoquininas), la elongación de las células fomentando el crecimiento (giberelinas, GAs), la correcta maduración de los frutos para una efectiva dispersión de las semillas (etileno), y el establecimiento del momento idóneo para la germinación que garantice que el individuo progrese de una forma adecuada (ácido abscísico, ABA), entre otros (Buchanan et al., 2000). Estas hormonas vegetales fueron descritas como fruto de la investigación en una gran variedad de especies vegetales que presentaban interés agronómico (maíz, arroz, cebada, trigo, ...). Sin embargo, alrededor de los años 80 apareció un nuevo concepto unificador. Basándose en que las diferentes especies vegetales poseen más características en común de las que las diferencian, los investigadores trataron de concentrarse en la investigación de especies modelo de fácil manejo, como Arabidopsis thaliana, que permitieran acelerar el conocimiento sobre la biología de plantas y extrapolarlo a las especies de interés agronómico (Harberd 2006). Fruto de esa idea, a lo largo de los años, a las cinco hormonas clásicas, se les han ido incorporando nuevas hormonas o reguladores del crecimiento como son: el 
ácido salicílico (SA), los jasmonatos (JA), las poliaminas, los brasinoesteroides y las estrigolactonas entre otros (Kuppusamy et al., 2009; Xie y Yoneyama 2010). La acción de cada una de estas moléculas por separado así como la interacción existente entre ellas es objeto de intensa investigación en la actualidad. Sin embargo, los modelos elaborados hasta la fecha resultan incompletos y apuntan a la existencia de nuevos reguladores del crecimiento todavía por caracterizar (Lopez-Bucio et al., 2006). Una nueva molécula reguladora que podría cubrir alguna de estas ausencias es el óxido nítrico (NO).

Hasta hace tan sólo dos décadas, se pensaba que el NO no tenia ningún papel en la regulación de la fisiología de ningún organismo, debido a su naturaleza reactiva. Sin embargo, en la actualidad, sabemos que el NO está involucrado en procesos que incluyen la resistencia a enfermedades, la adaptación frente a factores de estrés de tipo abiótico y también juega un papel importante en procesos de crecimiento y desarrollo (Besson-Bard et al., 2008b). No hay duda de que la investigación en NO es, hoy en día, uno de los campos más activos en ciencia en el que más de 7000 artículos han sido publicados el pasado año (basado en búsquedas en PubMed 2010).

El NO es una de las moléculas más simples y ubicuas de la atmósfera. Tiene una naturaleza gaseosa y radicalaria, y es producido biológicamente. Estas propiedades permiten al NO viajar dentro de las células e incluso atravesar membranas sin procesos dependientes de energía, permitiendo la comunicación entre células vecinas (Ignarro 1990). Debido a su rápido movimiento y eliminación, el NO es una molécula excepcional para la señalización, tanto intracelular como intercelular, de procesos fisiológicos (Neill et al., 2002b; Lamattina et al., 2003). El NO puede, además, interaccionar con otras moléculas señalizadoras contribuyendo a la amplificación de las cascadas de señalización. Su versatilidad confiere a esta molécula la propiedad de participar simultáneamente en diferentes compartimentos celulares e incluso en direcciones opuestas (Beligni y Lamattina 1999; Clarke et al., 2000; Beligni et al., 2002; Tada et al., 2004; Neill 2005; Mur et al., 2006). Así pues, el comportamiento del NO recuerda al de una hormona, aunque su naturaleza inorgánica la aleja de esta clase de moléculas.

Además, desde un punto de vista molecular, el NO actúa a diferentes niveles. Puede por un lado actuar sobre la expresión génica, regulando genes que cubren todos los aspectos del crecimiento y desarrollo, así como la respuesta a estrés (Huang et al., 2002; Polverari et al., 2003; Parani et al., 2004) y, por otro lado, puede actuar directamente sobre las proteínas modificando su actividad, localización, interacción, o degradación mediante su modificación post-traduccional (Gow et al., 2004). Aunque existen varios tipos de modificaciones post-traduccionales dependientes de NO, la nitrosilación de cisteínas y la nitración de tirosinas, han sido las más estudiadas desde el punto de vista de la señalización celular (Gow et al., 2004).

Años de investigación han resuelto que el papel señalizador del NO se extiende a todos los reinos, regulando procesos en organismos tan dispares como bacterias, protistas, hongos, animales y plantas. Esta conclusión apunta hacia un origen muy ancestral de esta molécula y de su 
utilización por parte de los organismos vivos. Se ha propuesto que en estadios tempranos de la evolución, el NO ejerció una actividad fundamentalmente antioxidante. Como consecuencia del desarrollo de organismos más complejos, nuevas y especializadas actividades antioxidantes coevolucionaron, por lo que el NO fue adquiriendo nuevas funciones contribuyendo así a la extensa y compleja red de señalización celular en la actualidad.

En los últimos años, la investigación sobre el NO en la biología de plantas ha contribuido a su caracterización como un regulador crucial del crecimiento y desarrollo de las plantas (Besson-Bard et al., 2008b). Los procesos que controla, cubren todo el ciclo vital de las plantas, interviniendo en la dormición y germinación de semillas, el crecimiento vegetativo, la floración, la fertilidad y la senescencia. Además, regula la adaptación frente a factores de estrés tanto de tipo biótico como abiótico (Delledonne et al., 1998; Beligni y Lamattina 2000; Bethke et al., 2004b; Pagnussat et al., 2004; He et al., 2004; Prado et al., 2004; Zeier et al., 2004; Hu et al., 2005; Guo y Crawford 2005; Correa-Aragunde et al., 2006; Mishina et al., 2007). El NO regula estos procesos, al menos en parte, mediante la interacción con las rutas de señalización de las diferentes hormonas (Delledonne et al., 1998; Dangl 1998; Tun et al., 2001; Desikan et al., 2002; Beligni et al., 2002; OrozcoCardenas y Ryan 2002; Guo et al., 2003; Pagnussat et al., 2004; Huang et al., 2004; Jovanovic et al., 2005; Bethke et al., 2006a; Lindermayr et al., 2006; Tun et al., 2006; Flores et al., 2008; Groppa et al., 2008). De una forma paralela, se ha descrito tanto la producción de NO tras la aplicación de diferentes hormonas como las auxinas (Pagnussat et al., 2002; Pagnussat et al., 2003; Kolbert et al., 2008b; a), citoquininas (Tun et al., 2001; Tun et al., 2008), ABA (Neill et al., 2002a; Bright et al., 2006), SA (Zottini et al., 2007), JA ((Huang et al., 2004), GAs (Bethke et al., 2004a) y poliaminas (Tun et al., 2006), como la modulación de los niveles de diferentes hormonas por NO (Huang et al., 2004; Xu et al., 2005; Gniazdowska et al., 2007; Mur et al., 2008; Liu et al., 2009b). Todos estos datos apuntan hacia un papel central del NO en el crecimiento y desarrollo vegetal mediante su interacción en la biosíntesis, metabolismo o señalización de las diferentes hormonas y reguladores del crecimiento. Debido a la diversidad de procesos que regula y a su interacción con las diferentes hormonas, la idea inicial que definía al NO como una molécula de respuesta a estrés, se está expandiendo ahora hacia una participación del NO en procesos del crecimiento y desarrollo en el que el NO juega un papel integrador.

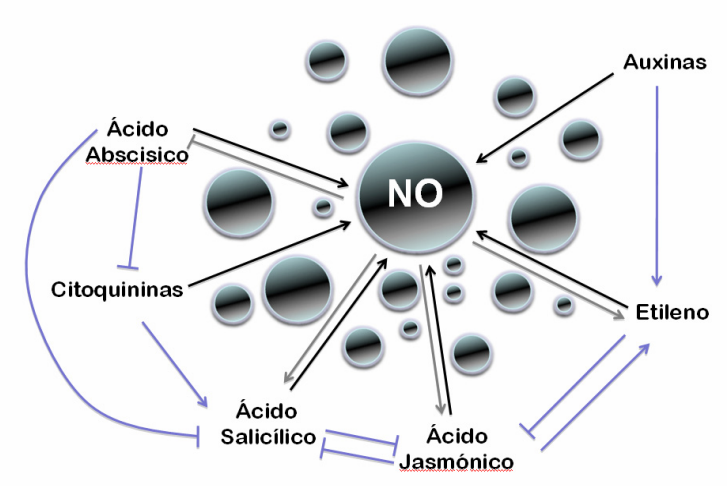

Figura 1. Esquema mostrando el papel integrador del NO en la señalización de las diferentes hormonas. 
Objetivos

OBJETIVOS 
Objetivos

\section{Objetivos}

El presente trabajo pretende analizar la biosíntesis, señalización y modo de acción del óxido nítrico (NO) en la planta modelo Arabidoposis thaliana. Para ello se plantean los siguientes objetivos:

1. Caracterización funcional de mutantes afectados en la síntesis de NO.

2. Estudio de la interacción del NO con el ácido abscísico en la regulación del desarrollo y las respuestas a estrés abiótico.

3. Estudio de la interacción funcional del NO con la señalización de las giberelinas en el control de la fotomorfogénesis.

4. Análisis del modo de acción del NO mediante la identificación proteómica de proteínas nitradas. 
CAPÍTULO 1: BIOSÍNTESIS DE ÓXIDO NÍTRICO 


\section{Introducción}

El óxido nítrico (NO) es una molécula gaseosa que regula el establecimiento de la defensa frente a bacterias, insectos, hongos y virus, y también la supervivencia de las plantas frente a condiciones ambientales adversas (Delledonne et al., 1998; Delledonne et al., 2001; Besson-Bard et al., 2008b; Qiao y Fan 2008; Gas et al., 2009; Leitner et al., 2009). Además, en los últimos años, se ha documentado su participación en la regulación de importantes procesos del crecimiento y desarrollo (Beligni y Lamattina 2000; Pagnussat et al., 2003; He et al., 2004; Prado et al., 2004), resultando ser una molécula clave durante todo el ciclo vital de la planta.

Los organismos, dependiendo de su naturaleza, están en contacto con NO tanto externo (atmósfera y suelo) como interno (el óxido nítrico producido por el propio organismo). Las principales fuentes de producción de $\mathrm{NO}$ en la atmósfera, son la utilización de combustibles fósiles y los incendios (Lamattina y Polacco 2007). Por otro lado, el NO producido en los suelos representa un $20 \%$ de su producción global (Conrad 1996), viéndose incrementado en suelos fertilizados (Johansson 1984; Bremer 2006). En el suelo, el NO es generado por el ciclo del nitrógeno llevado a cabo por bacterias denitrificantes mediante la reducción de nitrito $\left(\mathrm{NO}_{2}{ }^{-}\right)$a $\mathrm{NO}$ (Conrad 1996). Sin embargo, su impacto sobre el crecimiento y desarrollo de las plantas es todavía desconocido (Lamattina et al., 2003).

Por otro lado, el NO puede ser producido por el propio organismo y es el que tiene un papel más relevante sobre su fisiología. Una de las propiedades de la producción endógena de NO es que puede ser realizada tanto por mecanismos enzimáticos como no enzimáticos.

\section{- Mecanismos no enzimáticos de producción de óxido nítrico.}

Entre las vías no enzimáticas de producción de óxido nítrico destaca la reducción de $\mathrm{NO}_{2}$ a $\mathrm{NO}$ que tiene lugar en condiciones de pH ácido (Caro y Puntarulo 1999) que se ve incrementada con la presencia de reductores como el ácido ascórbico o el glutatión (Bethke et al., 2004a). Otra ruta no enzimática de producción espontánea de óxido nítrico es la reducción mediada por luz, del $\mathrm{NO}_{2}$ a NO en la que intervienen los carotenoides (Cooney et al., 1994; Durner y Klessig 1999). Cabe remarcar que las condiciones para la reducción no enzimática del $\mathrm{NO}_{2}$ a $\mathrm{NO}$ se dan en el apoplasto, por sus características ácidas, y ha sido utilizada para explicar el efecto del $\mathrm{NO}_{2}$ en la germinación (Beligni y Lamattina 2000; Bethke et al., 2004a)

\section{- Mecanismos enzimáticos de producción de óxido nítrico.}

En cuanto a las vías enzimáticas de síntesis de óxido nítrico, que aportan la mayoría del óxido nítrico al organismo, encontramos dos grupos bien diferenciados: La ruta dependiente de arginina y la ruta dependiente de nitrito. 


\section{- Ruta dependiente de arginina.}

El conocimiento que se tiene sobre este tipo de ruta viene heredado de la intensa investigación realizada en modelos animales que llevó a la identificación y caracterización de las óxido nítrico sintasas (NOS), enzimas que catalizan la síntesis de óxido nítrico (Bredt et al., 1990; Bredt y Snyder 1990). En células de mamíferos, la familia de NOS, compuesta por 3 isoformas altamente homólogas, es la fuente esencial de NO (Lamas et al., 1992). Todas las enzimas NOS catalizan la formación de óxido nítrico y L-citrulina a partir de L-arginina (Tayeh y Marletta 1989), mediante una reacción que requiere oxígeno y NADPH como cosustratos y la unión de un grupo hemo, tetrahidrobiopterina $\left(\mathrm{H}_{4} \mathrm{~B}\right)$, calcio, calmodulina, FAD y FMN como cofactores (Stuehr 1997). Las NOS se clasifican también en cuanto a su actividad que puede ser constitutiva (cNOS) o inducible (iNOS). Estas enzimas se han encontrado en varios compartimentos subcelulares, incluyendo la membrana plasmática, el retículo endoplásmico, la mitocondria y el citoplasma, en células animales. Esta compartimentalización es uno de los aspectos fundamentales que determinan su especificidad, ya que tal y como cabe esperar, el NO tendrá diferentes dianas dependiendo de donde se genere (Barouch et al., 2002).

En la búsqueda de enzimas con este tipo de propiedades en plantas se ha encontrado que varios tejidos producen L-citrulina a partir de L-arginina mediante un proceso que es dependiente de los cofactores típicos de NOS de mamíferos y son además inactivados por sus inhibidores (Delledonne et al., 1998; Barroso et al., 1999; Durner y Klessig 1999; Ribeiro et al., 1999; Corpas et al., 2001). Una evidencia más, acerca de la existencia de enzimas tipo-NOS en plantas fue la observación de la unión de anticuerpos producidos contra las NOS de mamíferos en germen de trigo, compartimentos citoplásmicos o nucleares de raíces de maíz, o peroxisomas y cloroplastos de guisante (Sen y Cheema 1995; Kuo et al., 1996; Barroso et al., 1999; Ribeiro et al., 1999; Corpas et al., 2001). Sin embargo, estos anticuerpos resultaron ser poco específicos (Lo et al., 2000; Butt et al., 2003) y ninguna de estas proteínas de plantas que reaccionan con los anticuerpos anti-NOS de mamíferos pudieron ser identificadas como NOS vegetales.

Continuando con el objetivo de identificar una NOS en plantas, el grupo del Dr. Klessig, en un extenso trabajo, consiguió purificar una proteína de tabaco que poseía actividad NOS (Chandok et al., 2003). Esta proteína cumplía todos los requisitos necesarios para ser una iNOS: tener una masa molecular muy similar a las NOS de animales, tener una actividad dependiente de $\mathrm{H}_{4} \mathrm{~B}$, NADPH, FAD, y $\mathrm{O}_{2}$, requerir $\mathrm{Ca}^{2+}$ y calmodulina $(\mathrm{CaM})$ para su actividad, ser inhibida por los inhibidores de NOS animales (L-NMMA y aminoguanidina), tener dependencia de arginina o NOHA como sustratos y, por supuesto, poseer actividad NOS medida por tres métodos independientes (Chandok et al., 2003). Este trabajo definió el locus At4g33010 que codifica la proteína varP (una variante de la proteína P del complejo glicina descarboxilasa, GDC) como la iNOS de plantas (Chandok et al., 2003). Además, el silenciamiento del gen varP de tomate (LevarP) daba lugar a una disminución 
en la producción de NO e incrementaba la susceptibilidad frente a Pseudomonas syringae DC 3000 (Chandok et al., 2004), reflejando la importancia de la proteína varP/iNOS en el establecimiento de la defensa frente a patógenos y corroborando los experimentos de Delledonne (Delledonne et al., 1998). Sin embargo, esta proteína no tenía ninguna homología con las iNOS de mamíferos, lo que resultaba muy interesante desde un punto de vista evolutivo.

Casi al mismo tiempo, el grupo del Dr. Crawford, identificó otra proteína tipo-NOS mediante una estrategia bioinformática (Guo et al., 2003). Se alinearon las secuencias de NOS animales y se compararon con las proteínas de plantas en busca de alguna que poseyera cierta similitud de secuencia con éstas. Sin embargo, no se encontró ninguna proteína similar a las NOS de animales en el genoma de Arabidopsis thaliana (Guo et al., 2003). No obstante, al ampliar la búsqueda a proteínas NOS atípicas de animales, encontraron una proteína tipo NOS atípica, del caracol Helix pomatia (Huang et al., 1997), que tenía un 16\% de identidad con una proteína desconocida de plantas (Guo et al., 2003). Esta proteína de plantas pasó a denominarse AtNOS1 y presentaba actividad NOS con ciertas excepciones: pese a ser dependiente de NADPH, $\mathrm{Ca}^{2+}$ y $\mathrm{CaM}$ era independiente de $\mathrm{FAD}, \mathrm{FMN}$ y $\mathrm{H}_{4} \mathrm{~B}$ lo que describía un comportamiento diferencial frente a las NOS animales (Guo et al., 2003). Un segundo nivel de evidencia descrita en el mismo trabajo era la baja acumulación de óxido nítrico que presentaban mutantes nulos para AtNOS1 (nos1) así como una actividad NOS reducida (20\% respecto a plantas silvestres) en extractos de dichos mutantes (Guo et al., 2003). Como este gen presentaba una regulación transcripcional casi nula, se propuso que la enzima que codifica debía ser una NOS constitutiva de plantas (cNOS). En un trabajo posterior, se postuló que su actividad era esencial para el establecimiento de la defensa contra Pseudomonas syringae (Zeidler et al., 2004).

La descripción de estas dos proteínas supuso inicialmente un gran avance y permitió caracterizar diferentes papeles del NO en el crecimiento y desarrollo de plantas a través del estudio de sus mutantes (Guo et al., 2003; He et al., 2004; Guo y Crawford 2005). Sin embargo, más tarde, el grupo del Dr. Klessig se retractó de los artículos publicados sobre la proteína varP y su presunta actividad NOS (Klessig et al., 2004b; Klessig et al., 2004a). De la misma manera, dos años más tarde, se describió la falta de reproducibilidad en la detección de la actividad NOS de la proteína AtNOS1 (Zemojtel et al., 2006a). Sin embargo, dado que el mutante nos 1 presentaba una clara reducción en los niveles de $\mathrm{NO}$, tanto en condiciones basales como en respuesta a inductores de su síntesis como el ácido abscísico (ABA) o los lipopolisacáridos (LPS), se sugirió que AtNOS1 debía intervenir en la producción de NO. Puesto que se desconocía si participaba de una forma directa o indirecta se re-nombró como AtNOA1 (proteína asociada con óxido nítrico 1) (Crawford et al., 2006).

Recientemente, las discrepancias sobre esta proteína continúan ya que se ha descrito que la proteína AtNOA1 no se localiza en la mitocondria, como se propuso inicialmente (Guo y Crawford 2005), sino en los cloroplastos (Flores-Perez et al., 2008). Además, se ha comprobado 
que AtNOA1 es, en realidad, una GTPasa cíclica con dominios permutados (cGTPasa; (Moreau et al., 2008)) que posiblemente afecta al ensamblaje de ribosomas, interfiriendo con la síntesis de proteínas en los cloroplastos. Aunque la conexión entre este tipo de actividad y su posible función en la biosíntesis de óxido nítrico no es obvia, la sobre-expresión de AtNOA1 conlleva un incremento en la producción de NO en diatomeas (Vardi et al., 2008) y en células de mamíferos (Zemojtel et al., 2006b; Parihar et al., 2008) pero no en plantas (Kato et al., 2008).

En conclusión, pese a detectar actividad NOS en extractos vegetales, no se ha conseguido identificar, hasta la fecha, ninguna proteína con actividad NOS en plantas. De todas formas, la detección de actividad NOS realizada habitualmente esta basada en la cuantificación del producto de su reacción, L-citrulina. Teniendo en cuenta que ha sido descrita la interferencia del arginosucinato en la detección de L-citrulina (Tischner et al., 2007), los trabajos realizados previamente deberían ser revisados y reinterpretados con cautela.

\section{- Rutas dependientes de nitrito.}

El nitrito puede reducirse hasta NO (Klepper 1987) y representa, por tanto, una fuente para su producción. En plantas, el nitrito es normalmente reducido hasta amonio por la acción de la Nitrito Reductasa (NiR) en el cloroplasto (Miflin 1974). El potencial papel de la NiR en la producción de NO ha sido desestimado, ya que líneas transgénicas de tabaco que sobreexpresan una construcción en antisentido de $\mathrm{NiR}$, en lugar de acumular menos NO producen una cantidad mayor (Morot-Gaudry-Talarmain et al., 2002). En cambio, otra enzima que puede reducir el nitrito es la Nitrato Reductasa (NR). Se trata de una enzima bi-funcional que puede reducir el nitrato a nitrito y, en menor proporción, el nitrito a NO (Harper 1981; Ryan et al., 1983; Dean y Harper 1988; Klepper 1990). La producción de NO a través de la actividad NR no sólo se da en plantas superiores (Rockel et al., 2002) sino que también tiene lugar en algas (Mallick et al., 1999; Sakihama et al., 2002), hongos (Takaya 2002) y bacterias (Gilberthorpe y Poole 2008). La producción de NO mediada por NR fue descrita inicialmente en las Nitrato Reductasas constitutivas de leguminosas (Harper 1981; Klepper 1987) y, posteriormente, en las Nitrato Reductasa de tipo inducible del citoplasma (Yamasaki et al., 1999; Yamasaki y Sakihama 2000). Además, la producción de óxido nítrico se reduce tras la aplicación de azida sódica, un conocido inhibidor de la actividad NR (Yamasaki 2000). Otra evidencia acerca de la producción de óxido nítrico mediada por NR es que utilizando nitrato marcado, ${ }^{15} \mathrm{~N}-\mathrm{NO} 3$, como sustrato de la NR se produce óxido nítrico marcado $\left({ }^{15} \mathrm{~N}-\mathrm{NO}\right)$ (Dean y Harper 1986).

Cabe destacar que la enzima NR está finamente regulada (Campbell 1999). Tiene una vida media de algunas horas y requiere nitrato y luz para su actividad. Además, su actividad puede caer drásticamente por fosforilación y la subsiguiente unión de un dímero de proteínas 14-3-3 y puede revertirse mediante desfosforilación (Lillo et al., 2004). Esta modulación de la actividad NR in vivo se correlaciona muy bien con la producción de NO (Rockel et al., 2002; Lillo et al., 2004). 
En Arabidopsis thaliana existen dos genes que codifican Nitrato Reductasas citoplasmáticas, Atlg77760 para NR1/NIA1 y At1g37130 para NR2/NIA2. Estos genes fueron identificados por el grupo del Dr. Crawford a partir de mutantes identificados en sendos rastreos en la búsqueda de mutantes resistentes a clorato, un análogo del nitrato que se metaboliza al producto tóxico clorito (Wilkinson y Crawford 1991; 1993). El mismo grupo aisló un doble mutante, nialnia2, que presenta una deleción en el gen NR2/NIA2 y una mutación puntual que altera la unión del cofactor Molibdeno al enzima, en el gen NR1/NIA1, quedando la actividad NR de estas plantas reducida a un $0,5 \%$ de la actividad que presenta una planta silvestre (Wilkinson y Crawford 1993). Ha sido descrito que este mutante esta afectado en la producción de NO, tanto a nivel basal como inducido (Desikan et al., 2002; Modolo et al., 2005; Yamamoto-Katou et al., 2006; Kolbert et al., 2008a; Seligman et al., 2008; Ribeiro et al., 2009), quedando probado el papel de las NR en la producción de NO. Hay que remarcar no obstante, que el mutante nialnia2 acumula alrededor de diez veces menos arginina que las plantas silvestres, lo que ha permitido sugerir que la menor producción de $\mathrm{NO}$ en dicho mutante podría ser el resultado también de una menor síntesis de NO por la vía dependiente de arginina (Modolo et al., 2005). Por último, cabe destacar que tanto las enzimas tipo NOS de animales como las NR de plantas poseen características comunes, siendo ambas flavoproteínas de la familia de las ferredoxina-NADPH reductasas (Lamattina et al., 2003). Incluso existen evidencias de la reducción de nitrito por parte de algunas NOS animales (Mikula et al., 2009).

Otra fuente de NO dependiente de la reducción de nitrito es la catalizada por la enzima Xantina Oxidoreductasa (XOR). Esta es, de nuevo, una enzima bi-funcional que se puede encontrar en la forma Xantina Deshidrogenasa (XDH) o en la forma, dependiente de $\mathrm{O}_{2}$, Xantina Oxidasa (XO). Mientras que la forma $\mathrm{XDH}$ tiene preferencia por $\mathrm{NAD}^{+}$sobre $\mathrm{O}_{2}$ como aceptor de electrones, la forma XO tiene una actividad estrictamente dependiente de $\mathrm{O}_{2}$ (Hesberg et al., 2004). Estas dos formas de la enzima se pueden interconvertir, reversiblemente mediante oxidaciones de residuos de cisteína (Stirpe y Della Corte 1969), o irreversiblemente por proteolisis (Amaya et al., 1990). La proteína XOR esta implicada en el metabolismo de purinas, componentes nitrogenados estructurales de los ácidos nucleicos. Mediante su actividad, este enzima, convierte hipoxantina o xantina en urato, que es posteriormente transformado en urea para finalmente producir amonio (Stasolla et al., 2003; Zrenner et al., 2006). La enzima XOR contiene dominios para la unión de cofactor de molibdeno (MoCo), FAD y NADPH, y dos agrupaciones sulfoférricas $\mathrm{Fe}_{2} \mathrm{~S}_{2}$, enmarcándose, al igual que las NOS de mamíferos y las NR de plantas, en la familia de flavoproteínas. Cualquiera de las dos formas activas del enzima, XDH o XO, reducen oxígeno molecular hasta superóxido y peróxido de hidrógeno, siendo esta propiedad una de las más estudiadas desde un punto de vista clínico.

Se ha propuesto que la actividad XOR puede producir NO en determinadas condiciones. Se ha demostrado la producción de NO tras incubar XOR con NADH y nitrato (Millar et al., 1997; 
Millar et al., 1998) o nitrito (Zhang et al., 1997; Millar et al., 1998; Godber et al., 2000a; Godber et al., 2000b; Li et al., 2001) bajo condiciones de hipoxia. Así mismo, Godber y sus colaboradores observaron una reducción en la producción de óxido nítrico cuando los niveles de oxígeno aumentaban lo que es consistente con el incremento en la producción de superóxido y la reacción de éste con NO formando peroxinitrito (Godber et al., 2000a; Godber et al., 2000b). Hay grandes diferencias entre las dos formas del enzima XOR en la producción de peroxinitrito, siendo la forma XDH la que produce peroxinitrito mayoritariamente (Godber et al., 2000a; Godber et al., 2000b). No obstante, se ha propuesto que, en bajas tensiones de oxígeno y concentraciones de purinas, se pueden producir cantidades de NO equivalentes a las producidas por las NOS animales (Li et al., 2001; Harrison 2002). Toda esta información procede de trabajos realizados utilizando modelos animales, ya que la capacidad de la XOR de producir NO en plantas ha sido únicamente postulada (del Rio et al., 2002; del Rio et al., 2004).

En Arabidopsis, a diferencia de la mayoría de organismos, encontramos dos genes que codifican sendas proteínas XOR (At4g34890, XOR1; At4g34900, XOR2) con una identidad del $93 \%$ entre ellas, sugiriendo que son producto de una duplicación génica. Mientras que XOR2 parece tener una expresión constitutiva, XORI responde a diferentes factores de estrés como sequía, salinidad, senescencia forzada por oscuridad y frío, así como a ABA, aunque estos cambios de expresión no siempre se correlacionan con cambios en la actividad de la enzima (Hesberg et al., 2004). Finalmente, el uso de mutantes ha demostrado un papel crucial de XOR en el crecimiento y desarrollo de Arabidopsis, en especial durante la senescencia (Nakagawa et al., 2007; Brychkova et al., 2008).

Además de estas dos vías enzimáticas de producción de NO mediadas por NR o XOR y dependientes de nitrito, existen otras mucho menos estudiadas que incluyen la mediada por la Nitrito:NO-Reductasa (Ni-NOR) en la membrana plasmática de células de raíces de tabaco (Stohr et al., 2001) o la reducción de nitrito a NO en la mitocondria (Planchet et al., 2005).

\section{Metabolismo del NO en plantas.}

En las células vegetales existen diferentes sistemas de detoxificación/eliminación/inactivación del NO. Entre estos sistemas, destacan la unión del NO al glutatión (GSH) y a la hemoglobina (Hb) (Perazzolli et al., 2006; Lee et al., 2008). El NO y el glutatión (GSH) pueden formar nitrosoglutatión (GSNO) mediante una reacción, todavía desconocida, que podría ser dependiente de citocromo c (Basu et al., 2010). El GSNO puede funcionar como un reservorio intracelular de NO ya que puede descomponerse, liberando NO, mediante la acción de nitrosoglutatión reductasas (GSNOR). Estas enzimas juegan un papel muy importante en la homeostasis de NO en la célula (Gupta et al., 2011). 


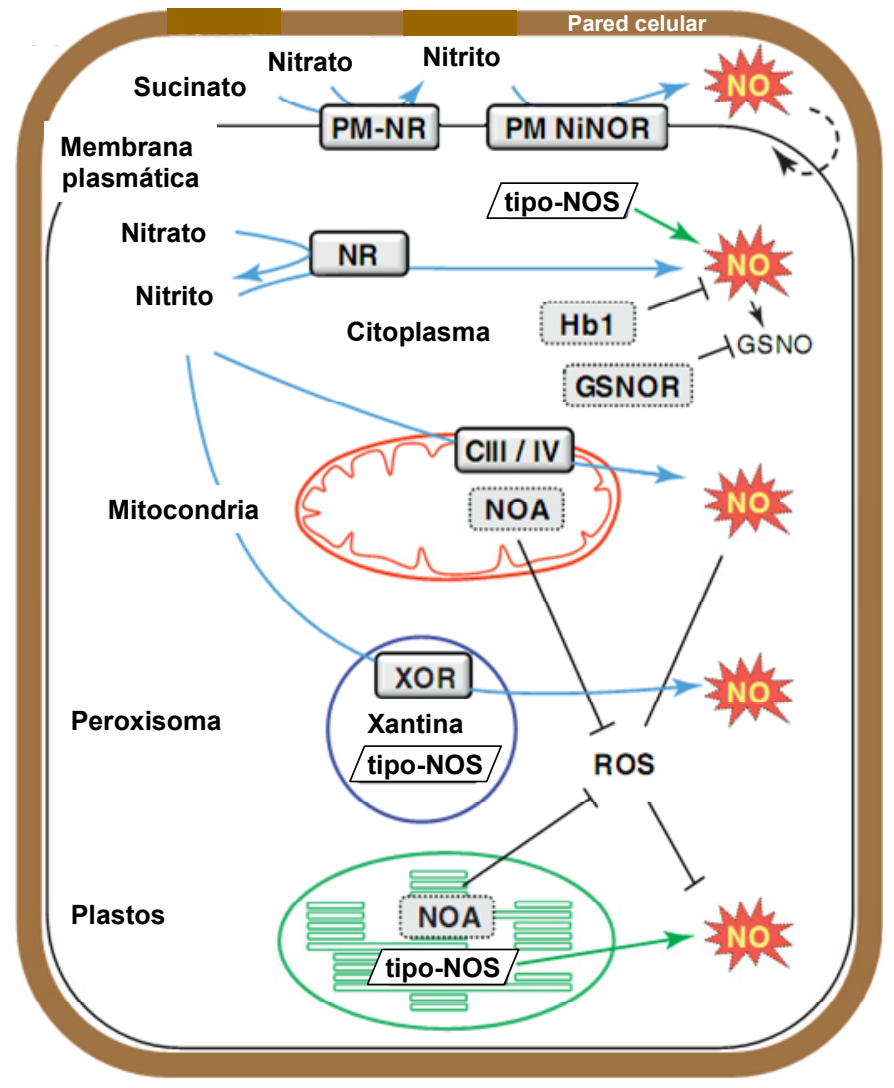

Figura 2. Síntesis de NO en plantas.

Esquema traducido de Gupta et al., 2011; mostrando las diferentes rutas de síntesis de NO y los compartimentos celulares donde se llevan a cabo.

Además, la correlación entre la actividad GSNOR y los procesos donde el NO tiene un papel importante es muy evidente, encontrando ejemplos muy claros en la defensa frente a bacterias y herbívoros (Diaz et al., 2003; Rusterucci et al., 2007), así como en el desarrollo de la raíz (Espunya et al., 2006). Por otro lado, la unión del $\mathrm{NO}$ a la hemoglobina $(\mathrm{Hb})$ de plantas, aunque estudiada en menor medida, es también un mecanismo de inactivación/detoxificación de NO (Perazzolli et al., 2006). De la misma forma, la reacción del NO con el ión superóxido, produciendo peroxinitrito, representa también un sistema de eliminación celular de NO (Crow y Beckman 1995). Además de estos dos mecanismos, la interacción del NO con las proteínas, tanto con diferentes aminoácidos como con centros metálicos de las mismas puede representar también un mecanismo de inactivación/eliminación del NO. Que este tipo de procesos representen mecanismos fisiológicos de control de los niveles de NO, es todavía un campo por desarrollar.

En el presente capítulo, hemos tratado de identificar y caracterizar mutantes afectados en varias de las rutas de síntesis de NO conocidas en plantas para posteriormente utilizarlos en el análisis de la interacción del NO con otras hormonas y procesos de desarrollo. 


\section{RESULTADOS}

\section{Caracterización de mutantes de las principales vías de biosíntesis de NO.}

Para caracterizar la vía de producción de NO a partir de nitrito mediada por nitrato reductasas, se procedió primero a identificar mutantes en cada uno de los genes NR1/NIA1 (At1g77760) y NR2/NIA2 (At1g37130) que codifican proteínas con actividad nitrato reductasa (Wilkinson y Crawford 1993). Haciendo uso de las colecciones públicas de mutantes de inserción de T-DNA seleccionamos líneas que tienen una inserción de T-DNA en cada uno de los genes NR1/NIA1 y NR2/NIA2 (Fig. 3). Estas son las líneas SALK_071547 para NR1/NIA1 y SALK_088070 para NR2/NIA2. Tras seleccionar individuos con la inserción de T-DNA en homocigosis por PCR (Fig. 3), pasamos a analizar el nivel de los correspondientes transcritos en estos mutantes para determinar si son mutantes nulos. Mediante oligonucleótidos que flanquean la inserción de T-DNA (Fig. 3, Tabla M2) llevamos a cabo RT-PCR semicuantitativa para determinar el nivel de los transcritos en dichos mutantes. Como se muestra en la Figura 4, hemos obtenido mutantes nulos para los genes NR1/NIA1 y NR2/NIA2. Por otro lado, debido a la posible redundancia de las dos proteínas sobre la producción de NO decidimos hacer uso del doble mutante, previamente caracterizado, nialnia2 (Wilkinson y Crawford 1993). Este mutante posee una deleción en el gen NR2/NIA2 así como una mutación puntual en el gen NR1/NIA1 y posee una actividad NR por debajo del 1\% de la actividad de una planta silvestre (Wilkinson y Crawford 1993). Estas mutaciones resultan en la ausencia de transcrito del gen NR2/NIA2 (Fig. 6) y aunque el gen NR1/NIA1 se transcribe normalmente (Fig. 6), codifica una proteína con un cambio de aminoácido Ala $\rightarrow$ Thr que reduce la actividad de esta proteína drásticamente (Wilkinson y Crawford 1993).

Por otro lado, en modelos animales, se ha propuesto que la actividad Xantina Oxido-Reductasa (XOR) dependiente de nitrito, puede ser responsable de la producción de NO bajo determinadas condiciones (Zhang et al., 1997; Millar et al., 1998; Zhang et al., 1998). En Arabidopsis, la XOR esta codificada por dos genes, XOR1 (At4g34890) y XOR2 (At4g34900) con una alta homología (Hesberg et al., 2004). Como ha sido postulado que este tipo de actividad puede ser también responsable de la producción de NO en plantas (del Rio et al., 2002; del Rio et al., 2004), obtuvimos mutantes de las colecciones públicas de inserciones de T-DNA nulos en ambos genes. Las líneas SALK_148366 y SAIL_722_C03 se llevaron a homocigosis, y las denominamos xor 1-1 y xor2-1, respectivamente (Fig. 3; Fig. 4; Fig. 6). Aunque los dos genes tienen patrones de expresión diferentes y a menudo no coincidentes (Hesberg et al., 2004), quisimos evitar la redundancia de estas proteínas, obteniendo el doble mutante xor1-1xor2-1 que no presenta transcrito para ninguno de los dos genes (Fig. 6) siendo, por tanto, un posible mutante sin actividad XOR. 


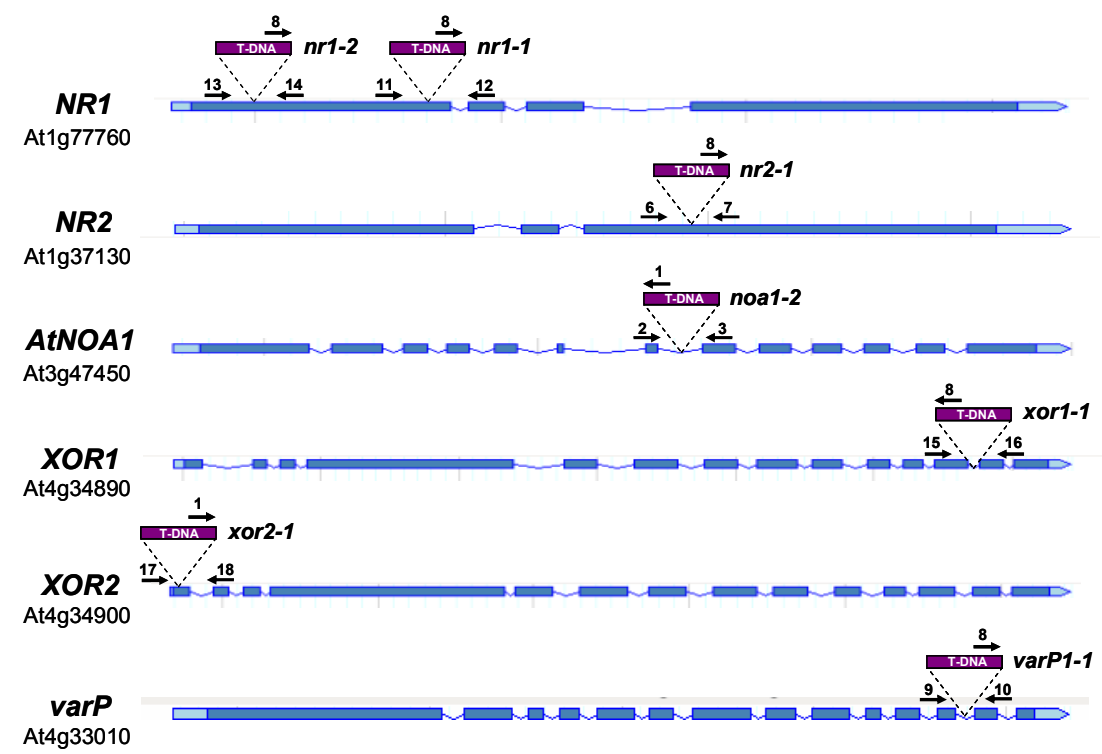

Figura 3. Esquema representando los diferentes mutantes (líneas de inserción de T-DNA) caracterizados en este trabajo. Se presenta el símbolo de cada gen junto a su locus (AGI) y la posición relativa de la mutación en cada caso. Los número representan los diferentes oligonucleótidos utilizados para genotipar cada línea y su secuencia se encuentra en la Tabla M2.

En cuanto a la ruta de producción de NO relacionada con la proteína AtNOA1, existe descrito un mutante nulo, noal, que presenta una clara reducción de los niveles de NO (Guo et al., 2003). Para tratar de dar más solidez a estos resultados aislamos y caracterizamos un nuevo alelo mutante en este gen. En la colección Syngenta de mutantes de T-DNA encontramos una línea, SAIL_507_E11, con inserción en el locus At3g47450, correspondiente al gen AtNOA1. Tras seleccionar individuos homocigotos para la inserción, comprobamos que no presentaban niveles detectables de transcrito AtNOA1 por RT-PCR semicuantitativa (Fig. 4), pasando a nombrar el mutante como noal-2 y el mutante descrito previamente como noal-1. 


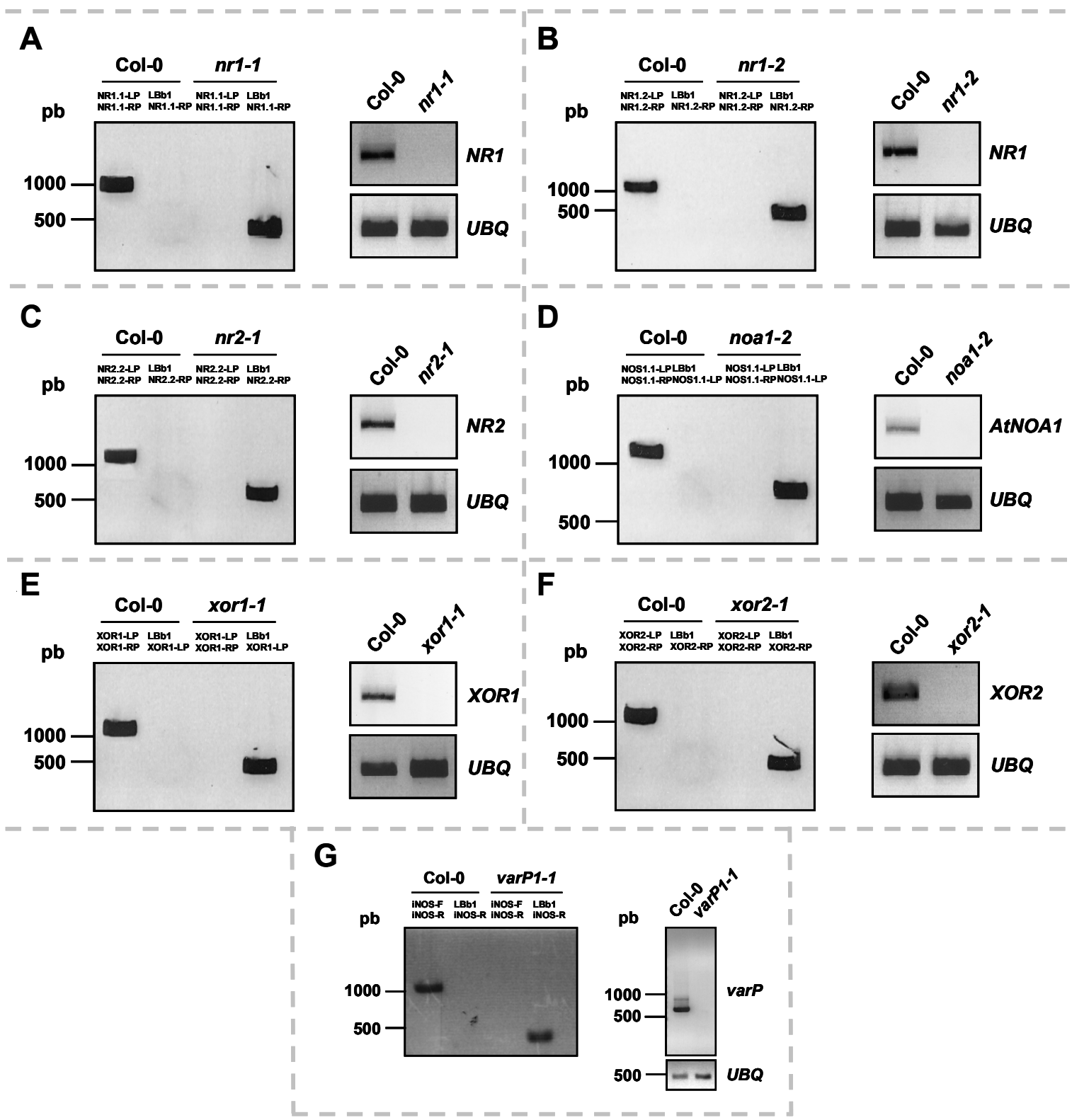

Figura 4. Identificación de mutantes nulos. (A-F) Se presentan los geles de agarosa teñidos con bromuro de etidio donde se separaron los diferentes productos de PCR tras usar los oligonucleótidos indicados sobre DNA genómico (panel izquierdo) o sobre cDNA, para comprobar el nivel transcrito (panel derecho). (G) Gel de agarosa teñido con bromuro de etidio (izquierda) y Southern-blot utilizando una sonda radiactiva correspondiente al gen varP (derecha).

\section{Producción de NO en los diferentes mutantes.}

Las fluoresceínas han sido muy utilizadas para la detección de NO en diferentes organismos, incluyendo las plantas, debido a su alta sensibilidad y a la simplicidad técnica (Planchet y Kaiser 2006). Una de estas fluoresceínas, el diacetato de diaminofluoresceína (DAF-FM DA) penetra en las células y reacciona con el NO convirtiéndose en un triazol que emite fluorescencia (con 
máximos de excitación y emisión a 500 y $515 \mathrm{~nm}$, respectivamente) y que es fácilmente detectable mediante fluorimetría o microscopía de fluorescencia. Ya que las raíces son un tejido carente de clorofilas y, por tanto, con muy poca autofluorescencia, han sido muy utilizadas para la detección de NO mediante fluoresceínas. De hecho, el análisis de la fluorescencia emitida por las diaminofluoresceínas en presencia de NO en las raíces es la técnica más utilizada para la detección de NO en plantas.
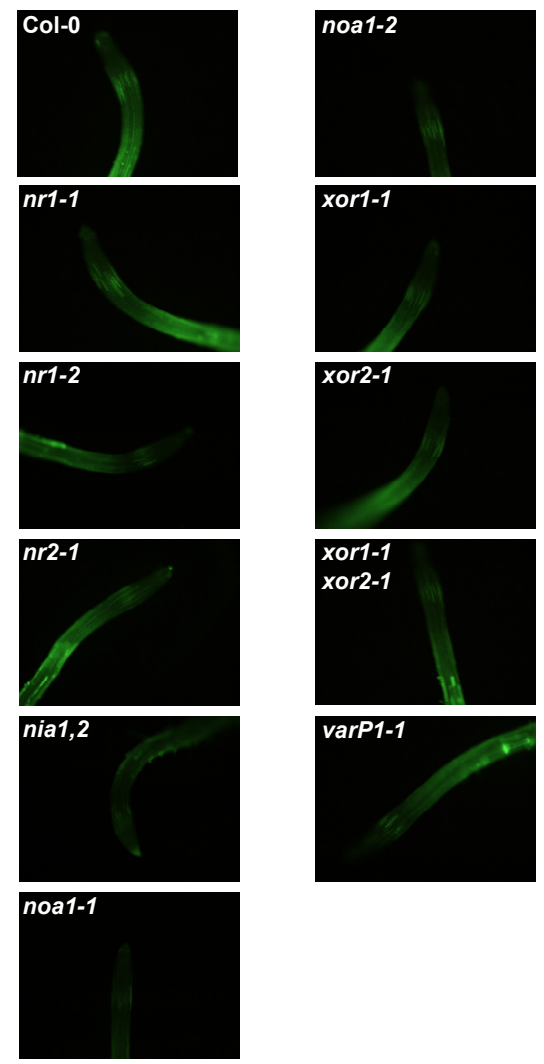

varP1-1

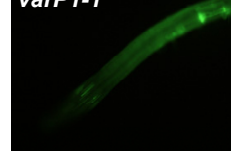

Figura 5. Determinación de la acumulación de NO en las raíces de los diferentes mutantes. Raíces de plántulas de 5 días teñidas con DAF-FM DA y visualizadas en el microscopio de fluorescencia. Se muestran imágenes representativas de los diferentes
Mediante la fluoresceína DAF-FM DA hemos caracterizado la producción de NO en los diferentes mutantes. Tras incubar las plántulas de los diferentes genotipos con DAF-FM DA y observar la producción de fluorescencia en las raíces mediante microscopia de fluorescencia, encontramos que solo se observaba una clara reducción en la producción de NO en los mutantes nialnia2, noal-1 y noal-2 (Fig. 5). En el caso de los demás mutantes no existe una clara reducción de los niveles de NO respecto al de plantas silvestres (Fig. 5). Estos datos ponen de manifiesto que el nuevo alelo noa1-2, como noa1-1, tiene una reducida producción de NO (Guo et al., 2003), lo que confirma la participación de la proteína AtNOA1 en la producción de NO en Arabidopsis. Por otro lado, los niveles de fluorescencia detectados en raíces de los mutantes simples $\operatorname{var} P$, xor 1 y xor 2, así como en el doble mutante xor1xor 2 no difieren significativamente de los detectados en

raíces de plántulas silvestres (Fig. 5), lo que indica que ni la vía de producción de NO dependiente de XOR ni la propuesta a través de la función de varP son funcionales en la producción de NO en raíces de Arabidopsis. De la misma manera, parece que la producción de NO en los mutantes sencillos $n r 1-1, n r 1-2$ y $n r 2-2$ no está afectada si bien la producción de NO en el doble mutante nialnia 2 está reducida respecto a las plantas silvestres poniendo en evidencia el papel redundante de NR1/NIA1 y NR2/NIA2 en la producción de NO. 


\section{Obtención y caracterización del triple mutante nia1nia2noa1-2}

Tras comprobar que las principales vías de síntesis de NO en Arabidopsis son las mediadas por NR1/NIA1, NR2/NIA2 y AtNOA1, y que ninguno de los mutantes analizados presentó una reducción total de la producción de $\mathrm{NO}$, decidimos generar un mutante afectado en las tres proteínas que nos permitiese profundizar en el estudio de la biosíntesis de NO en Arabidopsis. Para ello, cruzamos el doble mutante nialnia2 con noal-2 y buscamos en la progenie $\mathrm{F}_{2}$ individuos mutantes en los tres genes. Mediante genotipado por PCR, encontramos plantas homocigotas para las tres mutaciones (Fig. 6).

\section{A}

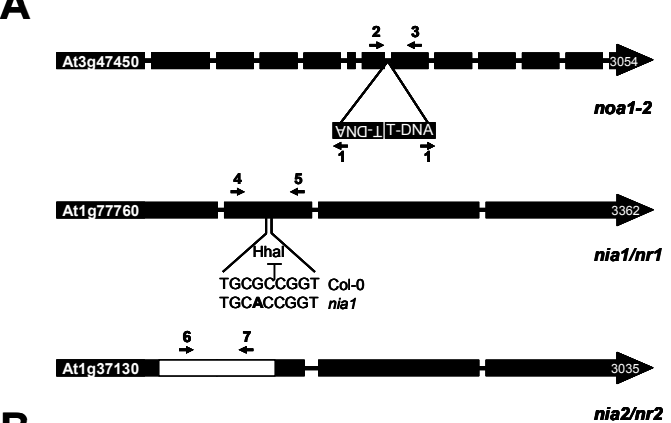

B

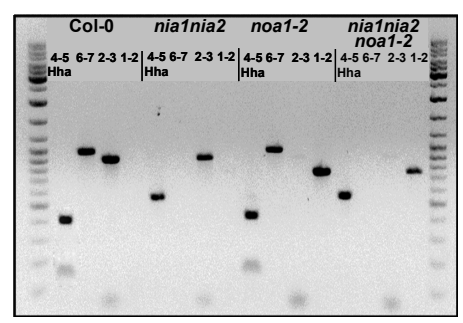

Figura 6. Generación y genotipado del triple mutante nia1,2noa1-2.

A. Esquema representando la posición de la inserción de T-DNA en AtNOA1, la mutación puntual en NIA1 y la deleción en NIA2. Los números representan los diferentes oligonucleótidos utilizados para genotipar las plantas. Se indica también la posición de corte del enzima HhaI en la secuencia NIAI en plantas silvestres pero no en mutantes nia1. B. Gel teñido con bromuro de etidio donde se muestra un resultado típico del genotipado de los diferentes mutantes.

Estas plantas, al igual que sus genotipos parentales, eran mutantes nulos para AtNOA1 y NR2/NIA2. Ya que nial es una mutación puntual que no afecta a la transcripción del gen, los niveles del transcrito mutante de NIAI eran similares a los niveles endógenos de plantas silvestres (Fig. 7).

A

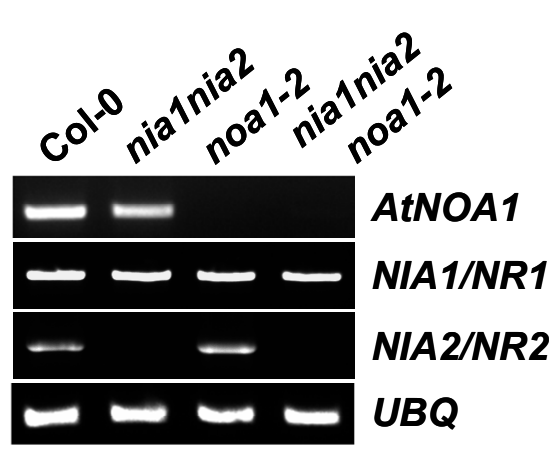

B

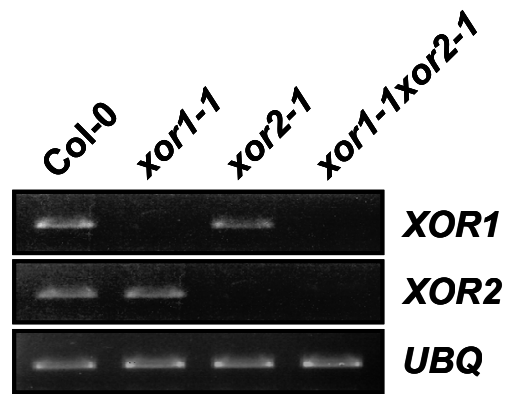


Figura 7. Análisis de la expresión de $A t N O A 1, N I A 1 / N R 1, N I A 2 / N R 2, X O R 1$ y XOR2 en los diferentes mutantes. Expresión de $A t N O A 1, N R 1$ y $N R 2$ (A) y XOR1 y XOR2 (B) en los mutantes indicados mediante RT-PCR semicuantitativa. Se analizó la expresión de Ubiquitina 10 (UBQ) como control.

Para comprobar si la mutación en los tres genes se traducía en una reducción de los niveles de NO se estudió la acumulación de NO en raíces de estos mutantes. Los niveles basales de fluorescencia dependiente de NO, que eran bajos en raíces no tratadas de individuos silvestres, se incrementaban de forma muy evidente tras tratar con diferentes compuestos como el ABA o el SA (Fig. 8). Dichos compuestos han sido descritos previamente como inductores de la síntesis de NO (Guo et al., 2003; Zottini et al., 2007). Nosotros encontramos que el ABA producía una mayor cantidad de NO y con una dinámica más rápida que el SA (Fig. 8). Además, la emisión de fluorescencia estaba asociada específicamente a la producción de NO ya que se observó una clara reducción en la emisión de fluorescencia en raíces

A

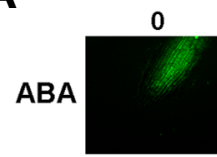

0

SA

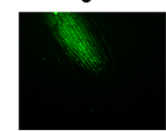

B

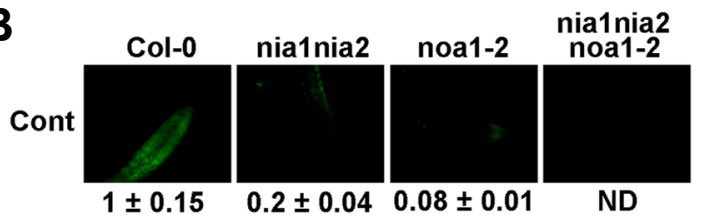

Figura 8. Producción de NO tras diferentes tratamientos o en los diferentes fondos genéticos deficientes en NO.

A. Producción de NO en raíces tratadas con $50 \mu \mathrm{M}$ ABA

o $1 \mathrm{mM}$ SA durante los tiempos indicados. B. Producción de NO en las raíces de los diferentes mutantes deficientes en NO. C. Producción de NO en plántulas enteras de los diferentes genotipos medida tras la aplicación de DAF-2 mediante fluorimetría.

C

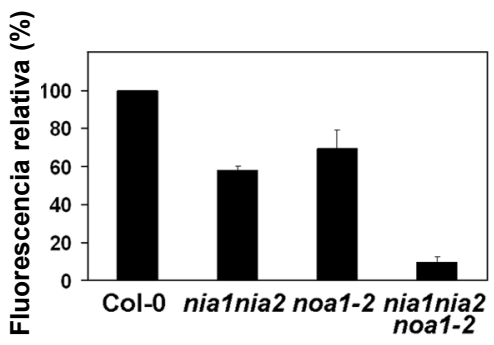

tratadas con SA en presencia del compuesto secuestrador de NO cPTIO (Fig. 8). Tras analizar la producción de NO en los mutantes deficientes en la síntesis de NO nialnia2, noal-2 y nialnia2noal-2 comprobamos que los niveles basales de acumulación de NO eran mucho menores en los mutantes nialnia2 y noal-2 que en raíces de plántulas silvestres, y por debajo de los límites de detección en el caso del triple mutante nialnia2noal-2 (Fig. 8). Por tanto, el mutante nialnia2noal-2 está muy afectado en la síntesis de NO en condiciones basales como resultado del bloqueo simultáneo de las rutas de síntesis de NO dependientes de las actividades NR/NIA y 
AtNOA1. Ya que la biosíntesis de NO puede ser diferente en diferentes órganos de la planta (Kolbert et al., 2008a; Seligman et al., 2008) y para excluir un posible efecto dependiente del tejido estudiado (raíz) analizamos también la acumulación de NO en plántulas enteras midiendo el NO que difunde al medio, fuera de las células, con la diaminofluoresceina no permeable a las células, DAF-2 y midiendo posteriormente la fluorescencia asociada al triazol formado (Fig. 8C). Para evaluar si la producción de NO detectada en plántulas del mutante nialnia2noal-2 era sintetizada biológicamente o químicamente, realizamos medidas con plántulas de los diferentes genotipos y las correspondientes plántulas inactivadas térmicamente, como control de la producción no enzimática de NO. Detectamos niveles similares de NO en todas las muestras correspondientes a plántulas inactivadas térmicamente que corresponde con la producción no enzimática de NO. Tras sustraer la producción de NO no enzimática, las plántulas nialnia2 y noal-2 acumularon un menor nivel de NO que las plántulas silvestres (Fig. 8C). Las plántulas nialnia2noal-2 mostraron una reducción aditiva de NO hasta niveles por debajo de un 10\% de los niveles detectados en plántulas silvestres (Fig. 8C).

\section{Las plantas deficientes en la producción de NO muestran alteraciones en el desarrollo}

Las plantas nialnia2noal-2 muestran una reducción en el crecimiento vegetativo tanto en la parte aérea como en la raíz, resultando en un fenotipo aditivo de los correspondientes a los mutantes parentales nialnia2 y noal-2 (Fig. 9). El retraso en el crecimiento se observa ya en estadios tempranos del desarrollo. La aparición de las primeras hojas verdaderas tiene lugar más tarde en las plantas deficientes en la producción de NO que en los individuos silvestres, siendo este fenotipo aditivo en las plántulas del triple mutante (Fig. 9). Las plantas adultas del triple mutante son semi-enanas con una altura y un diámetro reducido del tallo, siendo el $25 \%$ y el $37 \%$ del tamaño de las plantas silvestres, respectivamente (Fig. 9). El fenotipo semi-enano de la parte aérea se correlaciona también con un reducido crecimiento de la raíz, $56 \%, 35 \%$ y $15 \%$ respecto a las raíces silvestres para nialnia2, noal-2 y nialnia2noal-2, respectivamente. Esto causa una alteración en la proporción raíz-parte aérea en los mutantes deficientes en NO, siendo esta proporción en nialnia2noal-2 alrededor de tres veces más pequeña que en los individuos silvestres $(0,33 \pm 0,02$ y $0,12 \pm 0,01$, respectivamente). La deficiencia en NO correlaciona también con el reducido tamaño y número de silicuas, así como con una mayor frecuencia de semillas abortadas, lo que resulta en una reducida producción de semillas por planta (Fig. 9). 

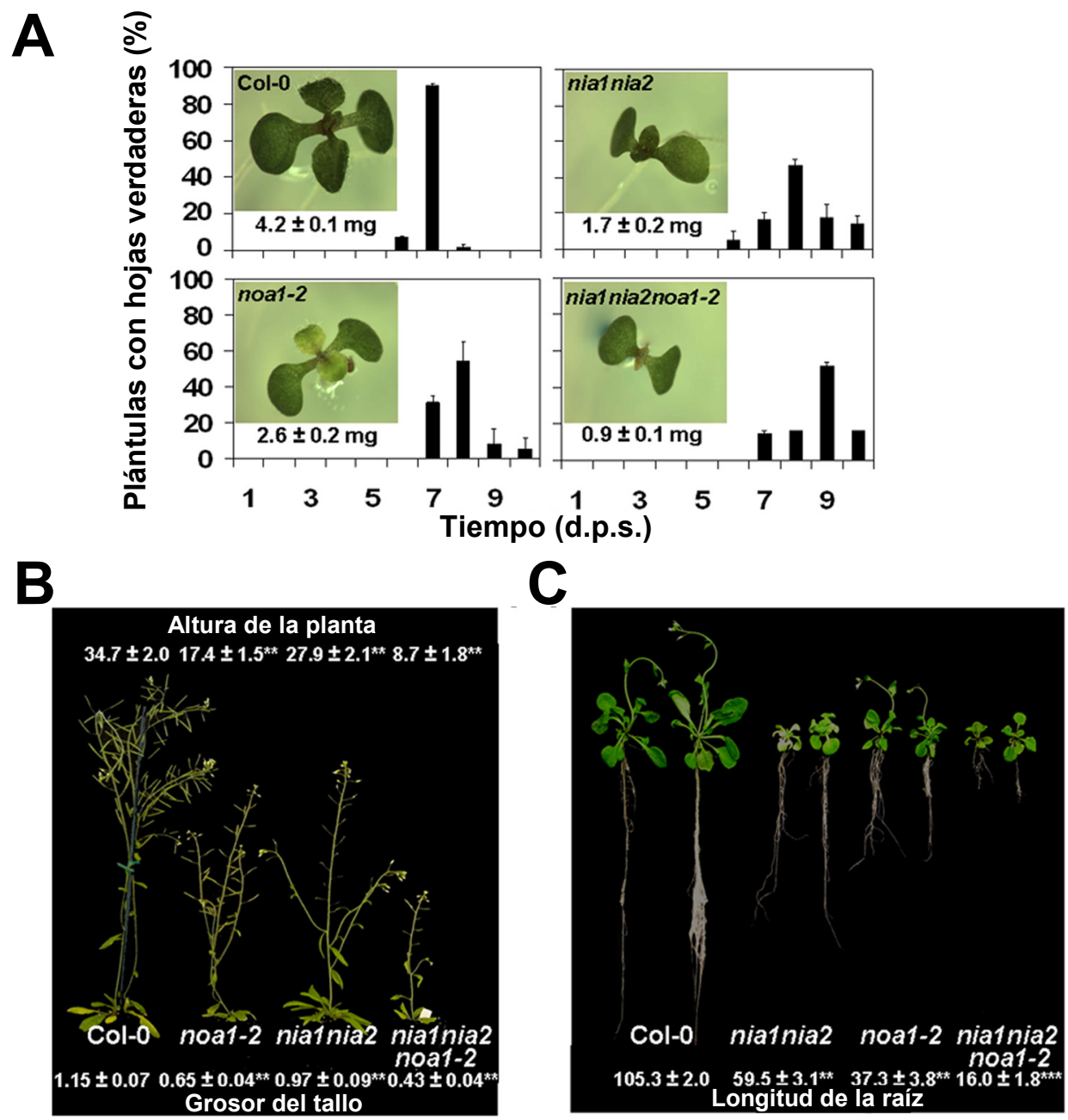

D

\begin{tabular}{|c|c|c|c|c|}
\hline Col-0 & noa1-2 & nia1nia2 & nia1nia2noa1-2 & \\
\hline $128 \pm 23$ & $69 \pm 5^{\star \star *}$ & $66 \pm 17 * *$ & $42 \pm 2 * *$ & Núm. Silicuas 1 \\
\hline $15.2 \pm 0.6$ & $13.0 \pm 0.8$ * & $14.2 \pm 0.5^{*}$ & $9.3 \pm 2.0 * *$ & Long. Silicuas $(\mathrm{mm})^{2}$ \\
\hline $0.8 \pm 0.2$ & $3.1 \pm 1.2$ ** & $8.6 \pm 3.1^{* k}$ & $24.0 \pm 6.1^{* *}$ & Esterilidad Silicuas $^{3}$ \\
\hline $72.4 \pm 4.6$ & $44.0 \pm 7.5$ * & $62.0 \pm 2.0 *$ & $33.3 \pm 6.8 * *$ & Semillas/Silicua ${ }^{4}$ \\
\hline
\end{tabular}

Figura 9. Diferentes fenotipos de los mutantes NO-deficientes. A. Frecuencia de plántulas con hojas verdaderas en función del tiempo post siembra en días (d.p.s.). Se incluye también el peso fresco en miligramos por plántula en cada mutante. B. La altura de la planta así como el grosor del tallo se midieron en plántulas cultivadas en tierra en condiciones de días largos. C. Longitud de la raíz principal de cada mutante en $\mathrm{mm}$. D. Se muestra el número de silicuas por planta, su longitud, su tasa de esterilidad, así como el contenido en semillas por silicua junto con imágenes correspondientes a silicuas de los diferentes genotipos. Se incluye una vista en detalle de la aparición de abortos en silicuas del triple mutante. Los valores corresponden a la media \pm desviación estándar y los asteriscos denotan una diferencia significativa en test-t $(* \mathrm{p}$-valor $<0,05 ; * *$ p-valor $<0,01 ; * * *$ p-valor $<0,0001)$.

Para determinar si el pequeño tamaño de las plántulas y la reducción del crecimiento de la raíz se debía a los niveles reducidos de NO, comparamos la longitud de la raíz principal y el peso de las plántulas de cada genotipo tratado o no tratado con el donador de NO, nitroprusiato sódico 
(SNP). La figura 10 muestra que el peso fresco de las plántulas enteras y la longitud de sus raíces eran entre el $20 \%$ y el $40 \%$ más largas en los mutantes nial nia 2 y noal-2 tratados con NO que en los controles no tratados. Este efecto era todavía más acusado en el caso del triple mutante nialnia2noal-2 siendo sus raíces entre un $90 \%$ y un $95 \%$ más largas tras tratar las plántulas con NO (Fig. 10). Estos datos muestran que el NO exógeno puede complementar alguno de los fenotipos de desarrollo de los mutantes deficientes en NO, apuntando a un papel específico del NO en estos procesos.

A

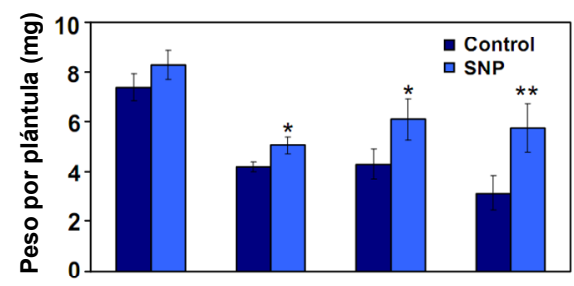

B

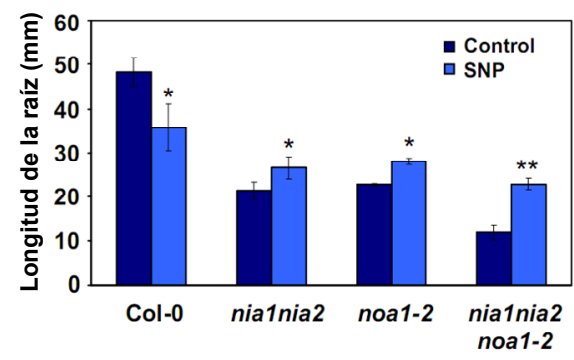

Figura 10. Complementación de alguno de los defectos en el desarrollo de los mutantes deficientes en NO mediante la aplicación de NO exógeno.

A. Peso por plántula de plántulas de 7 días tratadas o no con SNP. B. Longitud de la raíz en plántulas crecidas en vertical tratadas o no con SNP. Los valores son la media \pm desviación estándar. Los asteriscos denotan valores significativamente diferentes en un test-t $(*$ p-valor $<0,05$; ** p-valor $<0,01)$. La concentración de SNP utilizada fue de $100 \mu \mathrm{M}$.

\section{DISCUSIÓN}

Las evidencias obtenidas acerca del papel del NO en la regulación de un amplio conjunto de procesos en plantas contrastan con un conocimiento limitado y controvertido acerca de su biosíntesis. Sin embargo, muchos de los datos descritos acerca de la producción de NO y su función están basados en la aplicación de donadores y secuestradores de $\mathrm{NO}$ y en el análisis de dianas que no están directamente relacionadas con NO (Floryszak-Wieczorek et al., 2006; Arasimowicz-Jelonek et al., 2011). En este capítulo, hemos tratado de aislar, identificar y caracterizar mutantes afectados en las diferentes vías enzimáticas de síntesis de NO en Arabidopsis thaliana. El uso de estos mutantes nos ha permitido y nos ayudará en el futuro a establecer el papel del NO generado endógenamente en diferentes procesos, lo que será, sin duda, más informativo que el uso de las estrategias farmacológicas mencionados anteriormente (Floryszak-Wieczorek et al., 2006; Arasimowicz-Jelonek et al., 2011). Primero, hemos confirmado la participación de la proteína AtNOA1 en la síntesis de NO mediante la caracterización de un nuevo alelo mutante. Este alelo, noal-2, presenta al igual que noal-1, una reducida producción de NO, poniendo de 
manifiesto que esta proteína tiene un papel clave en la producción de NO. La reciente caracterización del homólogo de AtNOA1 en Nicotiana benthamiana apoya nuestros datos ya que el silenciamiento de NbNOA1 inducido por virus (VIGS) resulta en plantas de tabaco que acumulan menos NO (Kato et al., 2008). Sin embargo, no sabemos todavía como participa AtNOA1 en la producción de NO. La caracterización del mutante rifl plantea una posible función de AtNOA1/RIF1 en la correcta expresión de proteínas del plastoma en Arabidopsis (Flores-Perez et al., 2008). Así, el papel de AtNOA1 en la producción de NO puede estar íntimamente ligado a la función del cloroplasto (Flores-Perez et al., 2008) en lugar de la mitocondria (Guo y Crawford 2005). La reciente caracterización de AtNOA1 como una proteína de unión a GTP con un dominio circular permutado GTPasa (Moreau et al., 2008) indica un papel general de esta proteína en la función del ribosoma en la traducción de proteínas en el cloroplasto. Si existe una proteína concreta no traducida en los cloroplastos de noal-2 que controle la biosíntesis de NO o si el conjunto de proteínas no traducidas en los cloroplastos de noal-2 son las que repercuten en un menor contenido en $\mathrm{NO}$ en este mutante es un punto que no está resuelto todavía y que requiere de más trabajo.

Por otro lado, hemos confirmado también que la vía dependiente de las nitrato reductasas representa una contribución significativa a la producción de NO en Arabidopsis thaliana. En el doble mutante nialnia2, con una actividad nitrato reductasa prácticamente nula (Wilkinson y Crawford 1993), hemos detectado un menor contenido en NO que en plantas silvestres. El hecho de que mutantes sencillos en cada una de las nitrato reductasas presenten niveles de NO comparables a los de plantas silvestres apunta a un papel redundante de estas proteínas en la producción de NO en Arabidopsis. Así, cabría esperar que en mutantes afectados en una de las dos nitrato reductasas, hubiera una mayor actividad NR ejercida por la nitrato reductasa silvestre que corrigiera la actividad deficiente de la NR mutada. Ya que la actividad NR está finamente regulada, debe existir un mecanismo por el que se monitorice la actividad NR o los niveles de nitrato, ajustando su regulación para mantener un nivel correcto que permita el desarrollo normal de la planta, lo que sugiere un papel esencial de esta ruta en plantas. Esta hipótesis ha sido demostrada, al menos parcialmente, con el reciente descubrimiento del sensor de nitrato CHL1 (Ho et al., 2009).

Si bien las rutas de biosíntesis de NO dependientes de AtNOA1 y de la actividad NR parecen contribuir a la producción de NO en Arabidopsis, el posible papel de la actividad XOR no está tan claro. En animales, se ha descrito una producción de NO dependiente de nitrito y mediada por la actividad XOR (Zhang et al., 1997; Millar et al., 1998; Zhang et al., 1998). Además, existe también una interesante regulación mediante interacción proteína-proteína de las NOS de animales con las XOR (Tziomalos y Hare 2009), poniendo de manifiesto que no sólo la actividad, sino también la proteína XOR per se es importante para controlar los niveles de NO. Sin embargo, en Arabidopsis, ni mutantes sencillos en las dos xantinas oxidoreductasas ni un doble mutante xorl- 
1xor2-1 presentan una reducción clara en los niveles de NO en la raíz. Pese a que ambos genes, XOR1 y XOR2 son prácticamente idénticos, resultado probablemente de una duplicación génica, sus patrones de expresión son diferentes (Hesberg et al., 2004), apuntando a diferencias en sus regiones promotoras. Dichos genes se expresan de manera diferente en diferentes tejidos encontrando una mayor expresión en tejidos fotosintéticos que en raíces (Hesberg et al., 2004). Esto sugiere que quizás los niveles de proteínas XOR no sean muy importantes en raíces por lo que no seria de extrañar que no haya una diferencia significativa en los niveles de NO en las raíces del mutante xor1-1xor2-1. Así, si bien la actividad XOR o la propia proteína, participa de alguna manera en la producción de NO, sus mutantes deberían tener una menor acumulación de NO posiblemente en hojas o tejidos fotosintéticos más acentuada que en raíces. Sin embargo, la actividad XOR se regula también a nivel post-traduccional mediante la activación del holoenzima de manera que los niveles de proteína no siempre se correlacionan bien con los niveles de actividad (Hesberg et al., 2004). De hecho, pese a una diferencia importante en la transcripción de XOR1 y XOR2 en raíces y en hojas, la diferencia en actividad XOR no es tan importante. Así pues, se hace necesaria una caracterización más extensa de los niveles de NO en los diferentes tejidos y órganos de los mutantes sencillos xor1-1 y xor2-1 así como del doble mutante xor1-1xor2-1.

Ya que los mutantes nialnia2 y noal-2 presentaron una clara reducción en los niveles de NO y para obtener más información acerca de la contribución de ambas vías sobre la producción de NO en Arabidopsis obtuvimos el triple mutante nialnia2noal-2 mediante el cruce de sus genotipos parentales. Encontramos un efecto aditivo en la reducción de NO en el triple mutante comparado con sus genotipos mutantes parentales. El análisis de la producción de NO en plántulas completas indicó que el mutante nialnia2noal-2 producía todavía una cantidad residual de NO, alrededor del $10 \%$ del NO producido en plántulas silvestres. Esto puede ser explicado por la existencia de otra vía enzimática de producción de NO diferente de la mediada por las rutas AtNOA1 y NR. Esta ruta alternativa debe ser menos activa en raíces que en la parte aérea (Fig. 8). Si esta nueva vía de síntesis de NO esta relacionada con la actividad XOR es uno de los objetivos que estamos completando en el laboratorio. Sin embargo, ya que la aportación de esta nueva ruta es muy pequeña, alrededor de un $10 \%$, hace muy difícil establecer de forma inequívoca la naturaleza de esta actividad mediante los métodos utilizados. La generación de un quíntuple mutante nialnia2noa1-2xor1-1xor 1-2 o de plantas transgénicas que silencien la expresión de las dos XORs (Nakagawa et al., 2007) en el fondo genético nialnia2noal-2 aportará más información acerca de este fenómeno en un futuro. De todas formas, se hace necesaria la aplicación de metodologías alternativas que permitan cuantificar diferencias mas sutiles en la producción de NO.

Mediante el aislamiento y caracterización del triple mutante nialnia2noal-2 hemos podido establecer un importante papel del NO en procesos de desarrollo. Entre estos procesos destacan el desarrollo de la raíz, el crecimiento vegetativo y la fertilidad, donde el NO tendría un papel positivo. Esto fue comprobado mediante la complementación, al menos parcial, de la longitud de 
la raíz y del desarrollo vegetativo, a través de la aplicación de NO a plantas nialnia2noal-2. Es importante mencionar también, que el papel positivo que ejerce el NO sobre el crecimiento de la raíz se puede derivar únicamente de los resultados obtenidos en los mutantes deficientes en NO ya que la aplicación de NO a plántulas silvestres tuvo un efecto negativo (Fig. 10). Estos resultados apuntan hacia una regulación muy fina de los procesos de desarrollo por parte del NO donde niveles tanto por encima, como por debajo, de los óptimos, resultan en un defecto en el desarrollo, como ocurre con el control del crecimiento de la raíz y tal y como ha sido descrito para algunas hormonas (Mussig et al., 2003; Gonzalez-Garcia et al., 2011).

La caracterización de los mutantes generados en este estudio aporta información acerca de las rutas enzimáticas de biosíntesis de NO en Arabidopsis, quedando claro que las rutas dependientes de AtNOA1 y de NR son las que tienen un papel más importante en la producción de NO, si bien no podemos descartar una ruta adicional de síntesis de NO todavía no caracterizada y, ciertamente, menos importante desde el punto de vista cuantitativo que las mediadas por AtNOA1 y NR/NIA. Como se mostrará en los siguientes capítulos, el estudio del comportamiento de estos mutantes en diferentes procesos de desarrollo y de estrés aportará más información acerca de la participación de cada una de las rutas de producción de $\mathrm{NO}$ en estos procesos siendo una herramienta muy útil en el estudio del papel regulador del NO en plantas. 
CAPÍTULO 2: INTERACCIÓN ENTRE EL NO Y EL ABA EN PROCESOS DE DESARROLLO Y RESPUESTA A ESTRÉS 


\section{INTRODUCCIÓN}

\section{Interacción entre el NO y el ABA en procesos de desarrollo}

Junto a la función del $\mathrm{NO}$ en las respuestas frente a factores de estrés de tipo biótico (Delledonne et al., 1998; Bolwell 1999; Wendehenne et al., 2004; Leitner et al., 2009), su función en la adaptación frente a estreses de tipo abiótico ha sido muy estudiada en los últimos años (Lamattina et al., 2003; Graziano y Lamattina 2007; Zhao et al., 2007; Ribeiro et al., 2009; Gemes et al., 2011; Zhang et al., 2011).

El ácido abscísico (ABA) es la hormona que controla mayoritariamente las respuestas frente a factores de estrés de tipo abiótico teniendo un papel esencial en la adaptación frente a la sequía, las bajas temperaturas y la salinidad, entre otras (Schroeder y Nambara 2006; Sirichandra et al., 2009) Además, el ABA, ejerce un papel importante en la regulación del desarrollo en plantas (Chen et al., 2008a; Zhang et al., 2010; Shkolnik-Inbar y Bar-Zvi 2010) siendo clave en el control de la germinación de las semillas (Holdsworth et al., 2008a; Holdsworth et al., 2008b). El ABA, es un sesquiterpeno que se sintetiza a partir de la ruta de síntesis de xantoxina, localizada en los cloroplastos, que es convertida a aldehído abscísico y finalmente a ácido abscísico (ABA) en el citoplasma (Cutler y Krochko 1999; Gonzalez-Guzman et al., 2002). Por otro lado, el ABA, se cataboliza, mayoritariamente, por medio de proteínas de la familia de los citocromos P450 CYP707A, que lo convierten en ácido faseico (Kushiro et al., 2004; Saito et al., 2004) o ácido neofaseico (Okamoto et al., 2011), aunque su conjugación reversible con glucosa también ha sido descrita (Dietz et al., 2000; Hartung et al., 2002; Nambara y Marion-Poll 2005; Lee et al., 2006).

En los últimos años, ha existido una gran polémica en cuanto a su percepción ya que han sido descritos una serie de receptores que han sido descartados en trabajos posteriores (Razem et al., 2006; Shen et al., 2006; Gao et al., 2007; Liu et al., 2007; Razem y Hill 2007; Guo et al., 2008; McCourt y Creelman 2008; Risk et al., 2008). En la actualidad, los receptores de ABA que han sido aceptados son: GTG1 y GTG2, dos proteínas de membrana acopladas a proteínas G (Pandey et al., 2009), la subunidad H de la magnesio quelatasa cloroplástica CHLH, (Shen et al., 2006; Wu et al., 2009; Shang et al., 2010), y las proteínas codificadas por la familia génica PYR/PYL/RCAR (Ma et al., 2009; Park et al., 2009). Parece que las proteínas GTG1 y GTG2 ejercen su función a nivel de la membrana plasmática integrando las señales comunicadas por el ABA exógeno y transduciéndolas a través de segundos mensajeros intracelulares (Pandey et al., 2009). En cuanto a la proteína CHLH, pese a que no parece estar conservada (Muller y Hansson 2009), se cree que se localiza en la membrana del cloroplasto, con el extremo C-terminal orientado hacia el citoplasma (Shang et al., 2010), donde interacciona tanto con el ABA como con una serie de factores de transcripción que funcionan como reguladores negativos de la señalización del $\mathrm{ABA}(\mathrm{Wu}$ et al., 2009; Shang et al., 2010). De todas formas, la interacción con estos factores de transcripción en el 
citoplasma, así como su localización cloroplástica hacen de esta proteína un receptor poco común. Además, su transcripción esta bajo el control del reloj circadiano mediante la acción de TOC1 (Legnaioli et al., 2009). En cambio, los receptores PYR/PYL/RCAR se localizan en el citoplasma y el núcleo y, tras unir $\mathrm{ABA}$, inactivan protein-fosfatasas de tipo $2 \mathrm{C}$ que son fuertes represores de la señalización del ABA, permitiendo así una correcta señalización de esta hormona (Gosti et al., 1999; Merlot et al., 2001; Saez et al., 2004; Rubio et al., 2009; Park et al., 2009; Fujii et al., 2009; Cutler et al., 2010). Las estructuras a detalle atómico de varios miembros de esta familia han sido descritas recientemente, lo que representa un nivel de detalle acerca de su modo de acción sin precedente en el campo del ABA (Nishimura et al., 2009; Weiner et al., 2010; Peterson et al., 2010; Melcher et al., 2010). Además, la resolución de la estructura de diferentes PYR/PYLs/RCARs unidos a ABA pone claramente de manifiesto el papel de estas proteínas como receptores de ABA (Santiago et al., 2009; Weiner et al., 2010). Esta información ha sido integrada en la red de señalización de ABA conocida previamente permitiendo la simplificación del modo de acción del $\mathrm{ABA}$ pudiendo reconstituir el módulo principal de señalización del $\mathrm{ABA}$ in vitro (Fujii et al., 2009), lo que sin duda, abre nuevas puertas a la aplicación biotecnológica de toda esta información (Dupeux et al., 2011; Liang et al., 2011).

Entre los procesos regulados por el ABA, los más estudiados son la germinación de las semillas y el cierre estomático, procesos en los que el NO parece tener también un papel clave (Desikan et al., 2004; Neill et al., 2008).

La germinación de las semillas es un proceso altamente regulado donde se integran señales endógenas y exógenas que conducen a la selección del momento idóneo para la germinación y posterior desarrollo de la planta. Una de las particularidades de las semillas ha sido la adquisición, durante el transcurso de la evolución, de un estado fisiológico referido como dormición (FinchSavage y Leubner-Metzger 2006). La dormición se puede definir como un bloqueo en la germinación de una semilla viable bajo condiciones favorables (Bewley 1997). Este bloqueo de la germinación ha sido adquirido para garantizar la germinación solo en condiciones donde se pueda asegurar una nueva generación (Hilhorst 1990b; a; Li y Foley 1996; Bewley 1997). Por tanto, una semilla debe pasar de un estado durmiente a otro no durmiente para iniciar la germinación. No obstante, dependiendo de las condiciones, esta transición se puede revertir pasando al estado durmiente de nuevo (Finkelstein et al., 2008). Estas transiciones responden tanto a señales endógenas como exógenas que son integradas en rutas de señalización dependientes de diferentes hormonas y reguladores del crecimiento (Holdsworth et al., 2008a). Entre las hormonas, el ABA se presenta como el integrador fundamental de la germinación. Su papel en este proceso es el de inducir y mantener la dormición, inhibiendo, por tanto, la germinación (Koornneef et al., 2002; Gubler et al., 2005). Otra hormona que actúa en este proceso es el ácido giberélico y las estructuralmente asociadas giberelinas (GA) que tiene un papel opuesto al del ABA, siendo la proporción ABA:GA lo que determina la salida del estadio de dormición y la inminente 
germinación de la semilla (Finch-Savage y Leubner-Metzger 2006). Una alta proporción ABA:GA se traduce en ausencia de germinación mientras que altos niveles de GAs promueven la germinación (Finch-Savage y Leubner-Metzger 2006).

De forma paralela, el NO, ha sido caracterizado como un regulador de la dormición y de la germinación de semillas (Bethke et al., 2004b; Bethke et al., 2006a; Bethke et al., 2006b; Libourel et al., 2006; Sarath et al., 2006; Bethke et al., 2007). A este respecto, la mayoría del trabajo realizado se ha llevado a cabo mediante aproximaciones farmacológicas basadas en la aplicación de NO exógeno mediante donadores de NO o, excepcionalmente, de NO gaseoso (Keeley y Fotheringham 1998). Grubisic y colaboradores (1992) utilizaron nitroglicerina como donador de NO y sus análogos incapaces de liberar NO, triacetato de glicerol y glicerol. El tratamiento con nitroglicerina promueve la germinación de semillas de $P$. tormentosa mientras que sus análogos son totalmente inefectivos (Grubisic et al., 1992). Sin embargo, uno de los donadores de NO más utilizados es el nitroprusiato sódico (SNP) (Beligni y Lamattina 2000; Bethke et al., 2004b; Bethke et al., 2006a; Bethke et al., 2006b). A través de la aplicación de SNP, el NO es capaz de romper la dormición de Arabidopsis thaliana, algunas herbáceas y cebada (Bethke et al., 2004; Sarath et al., 2006). Originalmente, se describió que el NO es capaz de romper la dormición de las semillas pero no de semillas tratadas con ABA (Bethke et al., 2004b). Sin embargo, un trabajo posterior más completo concluyó que el NO era capaz de romper la dormición incluso de semillas imbibidas en ABA (Bethke et al., 2006a). Además, existen evidencias de que parte de este proceso se realiza en conexión con el etileno ya que embriones de manzana tratados con SNP son capaces de romper su dormición, mientras que un tratamiento conjunto de SNP y un inhibidor de la síntesis de etileno no favorecía la germinación (Gniazdowska et al., 2007). Recientemente, se ha descrito que la capa de aleurona es el determinante de la dormición y es el tejido de la semilla donde el NO junto con el ABA y las GAs ejercen su función (Bethke et al., 2007).

Aunque no queda duda de la actividad fisiológica del NO en la regulación de la ruptura de la dormición promocionando la germinación, su señalización en este proceso es todavía desconocida. Últimamente, se ha descrito el control de los niveles de ABA por NO como una parte de su señalización (Liu et al., 2009b). El NO regula tanto el transcrito como la acumulación de la proteína CYP707A2, encargada de la degradación de ABA (Liu et al., 2009b). El NO producido en la semilla, previo a la ruptura de la dormición, es capaz de incrementar la acumulación de la proteína CYP707A2 (Liu et al., 2009b). A su vez, los niveles de ABA disminuyen tras la producción de $\mathrm{NO}$ en la semilla en un individuo silvestre pero no en el mutante cyp707a2 (Liu et al., 2009b). Este mutante es incapaz de romper la dormición y de degradar ABA tras la aplicación exógena de NO (Liu et al., 2009b). Así pues, el NO puede reducir los niveles de ABA de las semillas mediante la activación de este enzima para romper la dormición y permitir la germinación. 


\section{Interacción entre el ABA y el NO en la regulación del cierre estomático}

La disponibilidad de agua es uno de los principales factores ambientales que afectan al correcto crecimiento de las plantas. Un déficit hídrico por un tiempo prolongado se traduce en pérdidas económicas importantes en las cosechas. Entre los efectos más importantes se encuentran la reducción en la fotosíntesis y en el metabolismo en general que se traduce en una parada en el crecimiento (Chaves et al., 2009; Skirycz et al., 2011a; Skirycz et al., 2011b). Así, la existencia de un conjunto de respuestas que promuevan una mayor tolerancia frente a la deshidratación es crítica para las plantas. Una de las respuestas más importante tras la percepción de la reducción del contenido en agua del suelo es el incremento en la síntesis y el transporte de ABA, que conduce rápidamente al cierre de estomas minimizando así la pérdida de agua (Sirichandra et al., 2009).

Los estomas están formados por una pareja de células de guarda, células epidérmicas especializadas que controlan el intercambio gaseoso y la evapo-transpiración de agua entre la planta y el ambiente (Sirichandra et al., 2009). Estas células, a través de la ganancia o pérdida de turgencia, dejan expuesto un poro que conecta el ambiente exterior con el interior de la estructura de la hoja. Bajo circunstancias de deshidratación, la planta responde con un incremento en los niveles y el transporte de ABA, a través de transportadores ABC (Kang et al., 2010; Kuromori et al., 2010; Kuromori y Shinozaki 2010), que se traduce en un movimiento coordinado de iones y agua a través de la membrana plasmática de las células de guarda. Esto produce una ganancia de turgencia de estas células y el concomitante cierre de este poro para evitar la transpiración y por ende la pérdida de agua. Controlar la apertura/cierre de este poro se hace indispensable para la supervivencia de las plantas frente a condiciones desfavorables (revisado por Sirichandra et al., 2009). Si bien las células de guarda controlan la apertura y cierre estomático en respuesta a fitohormonas (como el ABA) y varias señales ambientales como la luz, la temperatura o el ozono, en los últimos años se ha propuesto que diferentes especies reactivas de oxígeno y nitrógeno (ROS y RNS) podrían actuar como mediadores de la señalización del ABA (Zhang et al., 2001; Kwak et al., 2003). Entre estas especies, las que tienen un papel más importante en el cierre estomático son el $\mathrm{H}_{2} \mathrm{O}_{2}$ y el NO (Desikan et al., 2004).

Parece claro que el NO es uno de los intermediarios del cierre estomático inducido por ABA. Por un lado, el NO liberado por los donadores SNP y SNAP es capaz de cerrar los estomas de Vicia fava, mientras que el tratamiento con el secuestrador de NO, cPTIO, previene, aunque no totalmente, el cierre estomático promovido por ABA (Garcia-Mata y Lamattina 2001). Además, el SNP y otro donador de NO como el nitrosoglutatión (GSNO) son capaces de inducir el cierre de estomas en Arabidopsis thaliana y Pisum sativum, siendo este proceso dependiente de dosis (Desikan et al., 2002; Neill et al., 2002a). Sin embargo, esto es así para un rango de 
concentraciones de NO por encima del cual se provoca una reapertura de los estomas, indicando una compleja señalización del NO en este proceso (Magalhaes et al., 2005).

Otros estudios han puesto de manifiesto que las células de guarda son capaces de sintetizar NO y que se requiere de este NO para llevar a cabo el cierre estomático inducido por ABA (Desikan et al., 2002; Guo et al., 2003). La eliminación de NO mediante incubación con secuestradores como el PTIO o el cPTIO atenúa el cierre estomático inducido por ABA (Desikan et al., 2002; Garcia-Mata y Lamattina 2002; Neill et al., 2002a). Sin embargo, estos secuestradores no impiden el cierre estomático dependiente de ABA por completo por lo que se puede pensar que exista una vía para el cierre estomático dependiente de ABA e independiente de NO.

En cuanto a la fuente de producción de $\mathrm{NO}$ en las células de guarda existe cierta controversia. Se han adoptado diferentes estrategias para contestar a esta pregunta. Por un lado se han utilizado inhibidores de las NOS de mamíferos, como L-NAME, con probados efectos sobre la producción de NO en plantas (Barroso et al., 1999). La aplicación de este inhibidor se traduce en una reducción de los niveles de $\mathrm{NO}$ y del cierre estomático inducido por ABA en guisante (Neill et al., 2002a). Sin embargo, en Arabidopsis thaliana, el tratamiento con L-NAME no inhibe el cierre estomático mediado por ABA ni reduce los niveles de NO (Desikan et al., 2002). Esto no deja de ser sorprendente ya que ha sido probado por multitud de grupos el efecto de L-NAME (y de otros inhibidores de las NOS de mamíferos) sobre la producción de NO en Arabidopsis thaliana (Delledonne et al., 1998; Guo et al., 2003; Zhang et al., 2006; Zhang et al., 2007a; Romanov et al., 2008; Besson-Bard et al., 2009).

Al utilizar inhibidores de las NR, Desikan y colaboradores (2002) probaron la función de la actividad de este enzima en la producción de NO mediada por ABA y su correspondiente efecto sobre el cierre estomático. De esta manera, al incubar fracciones epidérmicas de hojas de Arabidopsis thaliana con tungstato, un conocido inhibidor de la actividad NR, los estomas no producían NO y eran incapaces de cerrarse tras aplicar ABA (Desikan et al., 2002). Además, la aplicación de tungstato no impedía el cierre estomático promovido por $\mathrm{SNP}, \mathrm{H}_{2} \mathrm{O}_{2}$ u oscuridad, indicando que los efectos del tungstato son fisiológicamente relevantes (Desikan et al., 2002). Además, mediante una aproximación genética basada en el uso del doble mutante nialnia 2 se comprobó que en este mutante no hay síntesis de NO en las células de guarda en respuesta a ABA y que tampoco se cerraban sus estomas en respuesta a esta hormona (Desikan et al., 2002). No obstante, los autores indican que no son capaces de observar un fenotipo de marchitamiento o una deshidratación acentuada en este mutante, lo que sería de esperar en una planta incapaz de cerrar los estomas por ABA (Desikan et al., 2002). Un trabajo posterior más detallado concluyó que el NO tiene un papel en el cierre estomático de plantas bien hidratadas pero no en plantas sometidas a una deshidratación previa (Ribeiro et al., 2009). Así, plantas turgentes del doble mutante nialnia2, no pueden cerrar sus estomas cuando se aplica ABA, tal y como se había descrito previamente (Desikan et al., 2002), pero lo hacen perfectamente si se aplica ABA a plantas que han sufrido un 
proceso de deshidratación previo (Ribeiro et al., 2009). Curiosamente, la aplicación de NO mediante SNP en plantas bien hidratadas, pese a provocar el cierre de estomas, no resulta en un mayor contenido de agua en la planta al final de los experimentos de deshidratación (Ribeiro et al., 2009). De la misma forma, la aplicación de cPTIO, pese a que impide el cierre de estomas mediado por ABA en plantas bien hidratadas, tampoco resulta en un menor contenido en agua como sería de esperar (Ribeiro et al., 2009).

Se disponen de algunas evidencias farmacológicas y genéticas en cuanto a la señalación por la que el NO regula el cierre estomático aunque su mecanismo se desconoce en su mayor parte. Así, mutantes afectados en la biosíntesis de ABA, como el mutante abal-1, responde menos que una planta silvestre al cierre de los estomas de plantas turgentes mediado por NO (Ribeiro et al., 2009). Estos datos sugieren que una parte de la señalización del NO depende de la biosíntesis de ABA mientras que, por otro lado, el NO puede regular el cierre de estomas de manera independiente a la acumulación de la hormona (Ribeiro et al., 2009). En cuanto a la posición del NO dentro de la ruta de señalización de ABA, existen algunas evidencias que posicionan al NO en los pasos iniciales de esta ruta. Los mutantes de ganancia de función insensibles al ABA, abil-1 y abi2-1, no responden al NO en el cierre estomático (Desikan et al., 2002; Ribeiro et al., 2009; Dubovskaya et al., 2011). Además, el mutante abil-1 tampoco responde a cGMP, un segundo mensajero del NO, en el cierre estomático (Dubovskaya et al., 2011). Por tanto, se puede afirmar que el NO actúa por encima de las fosfatasas PP2C ABI1 y ABI2 en la regulación del cierre estomático. A la luz de la reciente descripción de los receptores solubles de ABA, PYR/PYL/RCAR, puede postularse la hipótesis de que el NO este actuando directamente sobre estos receptores mediante la regulación de su transcripción o bien modificando su función mediante la modificación post-traduccional de los mismos.

Por otro lado, hay abundante información bibliográfica que sustenta que el NO parece ejercer su función en el cierre estomático a través de tres vías principalmente: la producción de GMP cíclico (cGMP), la producción de ADP-ribosa cíclica (cADPR) y la liberación de calcio.

Ruta dependiente de cGMP:

Se han descrito algunos resultados contradictorios en el posible papel del cGMP en el cierre estomático. Si bien el cGMP parece necesario para la apertura de estomas inducida por auxinas (Cousson 2001), existen resultados que prueban que el cGMP es requerido para la inducción del cierre estomático mediado por ABA y NO (Neill et al., 2002a; Dubovskaya et al., 2011). Además, la inhibición de la actividad guanilato ciclasa (GC), reponsable de la formación de cGMP, resulta en una reducción tanto de la apertura de los estomas mediada por auxinas como del cierre estomático inducido por NO (Cousson 2001; Neill et al., 2002a; Dubovskaya et al., 2011). Sin embargo, la aplicación del donador permeable de cGMP, 8-Br-cGMP, no es capaz de inducir el cierre estomático (Neill et al., 2002a; Lyudmila et al., 2011). Estos resultados indican que la 
producción de cGMP es necesaria pero no suficiente para el cierre estomático (Neill et al., 2002a; Neill et al., 2002b; Dubovskaya et al., 2011). Por tanto, el cGMP debe actuar junto con otros mensajeros en la regulación del movimiento estomático dependiente de NO. Es necesario determinar otros factores que junto al cGMP medien su señalización donde el calcio puede tener un papel muy importante (Dubovskaya et al., 2011).

cADPR y calcio:

El calcio es una molécula esencial en la señalización del ABA en los estomas siendo necesaria para una respuesta total al ABA aunque el cierre estomático en ausencia de calcio también ha sido descrito (Webb et al., 2001; Roelfsema y Hedrich 2010). Tanto la entrada de calcio desde el espacio extracelular como la liberación desde los reservorios intracelulares son requeridos para una correcta respuesta a ABA (MacRobbie 2000). Recientemente, se ha caracterizado que el $\mathrm{Ca}^{2+}$ extracelular es percibido por un receptor acoplado a la membrana plasmática de las células de guarda (Han et al., 2003) y que conduce a un incremento del $\mathrm{Ca}^{2+}$ intracelular (Allen y Schroeder 2001). Sin embargo, parece que debe existir otro sistema que perciba el $\mathrm{Ca}^{2+}$ extracelular, siendo la calmodulina, un buen candidato para ejercer esta función ( $\mathrm{Li}$ et al., 2009). La calmodulina extracelular (ExtCaM) se encuentra localizada en la pared celular de las células de guarda y, cuando su actividad en inhibida, se promueve la apertura de estomas bajo condiciones de luz mientras que se inhibe el cierre estomático inducido por oscuridad en $V$. fabia y A. thaliana (Chen et al., 2004), probando así el posible papel de ExtCaM en el cierre estomático. Se ha probado también que el $\mathrm{Ca}^{2+}$ extracelular, a través de su percepción por ExtCaM, desencadena una ruta de señalización que incluye a la subunidad $\alpha$ de la proteína $\mathrm{G}$ ( $\mathrm{Li}$ et al., 2009a). Esta a su vez, promueve la activación de la producción de $\mathrm{H}_{2} \mathrm{O}_{2}$ dependiente de AtrbohD/F que promueve la síntesis de NO dependiente de AtNOA1 para, finalmente, provocar el cierre estomático (Li et al., 2009). Se ha descrito también que el cGMP, cuya acumulación se activa tras la producción de $\mathrm{NO}$ inducida por $\mathrm{H}_{2} \mathrm{O}_{2}$, desencadena la liberación de $\mathrm{Ca}^{2+}$ citoplasmático (Dubovskaya et al., 2011). Este proceso puede estar mediado por proteínas que interaccionan con cGMP como las nucleósido-difosfato kinasas (NDPKs) (Dubovskaya et al., 2011). Por otro lado, la liberación del calcio intracelular puede darse por otras dos vías alternativas. Una de ellas dependiente de vesículas sensibles a inositol-1,4,5-trifosfato $\left(\mathrm{IP}_{3}\right)$ y otra sensible a los niveles de cADPR. La cADPR es capaz de promover un cierre parcial de los estomas de Commelina communis, donde el tratamiento con un antagonista del cADPR o con un inhibidor de su síntesis (como la nicotinamida) reducen el cierre estomático y el flujo de iones a través de la membrana plasmática de la vacuola provocados por el ABA (Leckie et al., 1998; MacRobbie 2000). En guisante, el cierre de estomas inducido por ABA o por NO se atenúa tras la aplicación de nicotinamida (Neill et al., 2002a). Además, la activación de la expresión de la ADPR ciclasa de Aplysia induce un incremento en los niveles de cADPR y un cierre parcial de estomas en 
Arabidopsis thaliana (Neill et al., 2002a; Dodd et al., 2007). Todos estos datos ponen de manifiesto la posible conexión entre el NO y la producción de segundos mensajeros como parte fundamental de la señalización del NO en el cierre estomático.

\section{RESULTADOS}

El NO ha sido caracterizado como un regulador de la dormición, la germinación, el cierre de estomas y el daño oxidativo, procesos donde el ABA ejerce un papel clave (Bethke et al., 2004b; Bethke et al., 2006a; Bethke et al., 2007; Qiao y Fan 2008). Sin embargo, la mayoría de trabajos realizados al respecto fueron llevados a cabo mediante aproximaciones farmacológicas basadas en la aplicación de donadores de NO, muchos de los cuales liberan productos diferentes al NO que interfieren con su análisis (Bethke et al., 2004b; Bethke et al., 2006a; Bethke et al., 2007). Si bien existen trabajos apoyando la función de NR/NIA y AtNOA1 en las interacciones ABA-NO (Desikan et al., 2002; Guo et al., 2003; Bethke et al., 2007), es necesario un análisis en detalle de la función de estas vías de síntesis de $\mathrm{NO}$ en la regulación de la función del $\mathrm{ABA}$ en estos procesos. Como se comentó en detalle en el capítulo anterior, la perdida de función simultánea de los genes NIA1/NR1, NIA2/NR2 y AtNOA1, supone una drástica reducción de los niveles de NO en plántulas de Arabidopsis. El triple mutante y sus genotipos parentales, son una herramienta muy interesante para estudiar desde un punto de vista genético, la interacción entre el NO y el ABA.

La producción de NO activada por ABA esta comprometida en los mutantes NO deficientes

El ABA es un fuerte inductor de la producción de NO (Guo et al., 2003) y, si bien las principales vías de síntesis de NO parecen ser las dependientes de las actividades NR/NIA y AtNOA1 (Moreau et al., 2010), no existía evidencia de la aportación conjunta de estas vías de síntesis en la producción de NO dependiente de ABA. Para obtener esta información, se determinó la acumulación de NO en raíces de plántulas silvestres y los mutantes de cada una de estas rutas, nial,2 y noa 1-2, así como la combinación de ambas, nia1,2noal-2, en condiciones basales o tras tratar las plántulas con ABA. Los niveles de 
NO en raíces de plántulas no tratadas resultaron estar muy reducidos en el caso de nial,2 y noal-2 e indetectables en el triple mutante nia1,2noal-2 (Fig. 11).

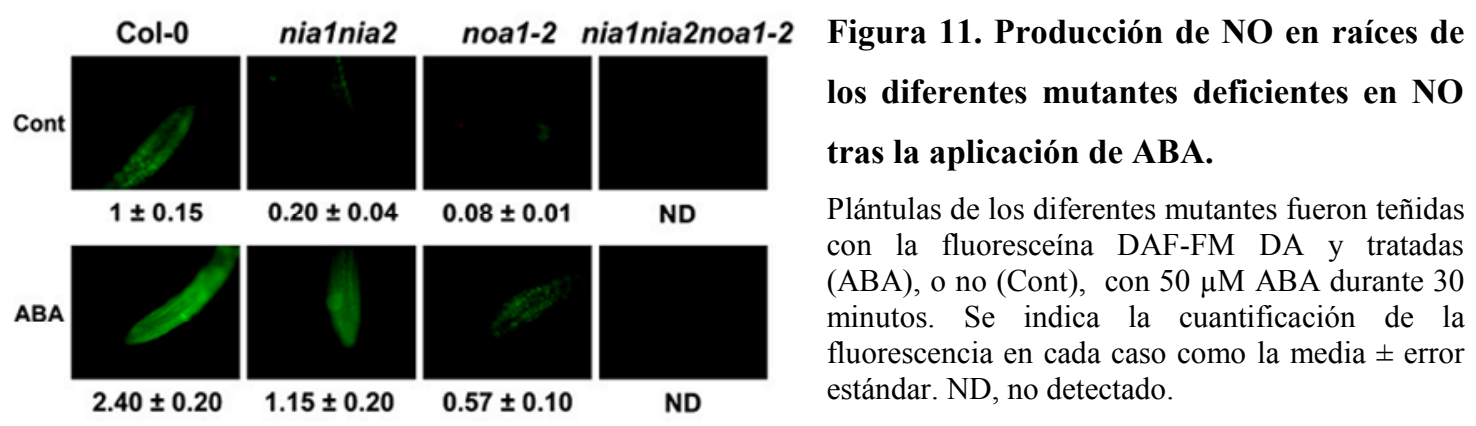

Cuando se trataron las plántulas con $\mathrm{ABA}$, las raíces de las plántulas silvestres mostraron un incremento en la fluorescencia asociada a NO tal y como esta descrito (Guo et al., 2003). Sin embargo, en el caso de los mutantes los niveles de NO tras la aplicación de ABA fueron claramente menores que los detectados en raíces silvestres (Fig. 11). Esta reducción fue todavía más evidente en el caso del triple mutante donde no se detectó fluorescencia asociada a la producción de $\mathrm{NO}$, quedando claro que ambas vías cooperan en la producción de $\mathrm{NO}$ activada por ABA (Fig. 11). En conclusión, como resultado del bloqueo simultáneo de las rutas dependientes de NIA/NR y AtNOA1, el triple mutante está afectado tanto en la producción basal de NO como en la inducida por ABA.

Interacción entre el NO y el ABA en el control de la dormición, la germinación y el establecimiento de plántula

El ABA inhibe la germinación y es esencial para la adquisición y el mantenimiento de la dormición (Koorneef et al., 2002; Gubler et al., 2005). Para determinar la posible conexión entre el ABA y el NO en la regulación de estos procesos, se contabilizó la germinación, cada 24 horas y durante 6 días consecutivos, de semillas durmientes de Col-0 y de los mutantes deficientes en NO, tras su siembra y cultivo sin previa estratificación en placas MS. Mientras que las semillas durmientes del genotipo silvestre presentaron un 20\% de germinación dos días después de su siembra, los mutantes deficientes en NO apenas alcanzaron un 5\% (Fig. 12A). Además, mientras que las semillas silvestres alcanzan su máximo potencial de germinación (80\%) 5 días después de la siembra, las semillas de los mutantes noal-2, nial,2 y nial,2noal-2 alcanzan tan sólo un 65\%, $25 \%$ y menos de un $10 \%$ de germinación 6 días después de la siembra, respectivamente. Para determinar si la mayor dormición de las semillas de plantas NO deficientes se debe a una reducida 
acumulación de NO, semillas durmientes de todos los genotipos se mantuvieron en un ambiente enriquecido en $\mathrm{NO}$ y su germinación se contabilizó 5 días después de la siembra. Todos lo genotipos deficientes en la producción de NO mostraron una reversión de su fenotipo de dormición tras ser tratadas con NO (Fig 12A, panel derecho). Sin embargo, mientras las semillas noal-2 germinaron como las semillas silvestres tras aplicar NO, las semillas de nialnia2 y de nialnia2noal-2 no revertieron totalmente su dormición (Fig. 12A, panel derecho). De todas formas, el tratamiento con NO permitió germinar al $40 \%$ de las semillas del mutante nialnia2noal-2 en contraste con el 6\% de germinación que alcanzan estas semillas en ausencia de NO exógeno en las condiciones estudiadas (Fig. 12A, panel derecho).

A
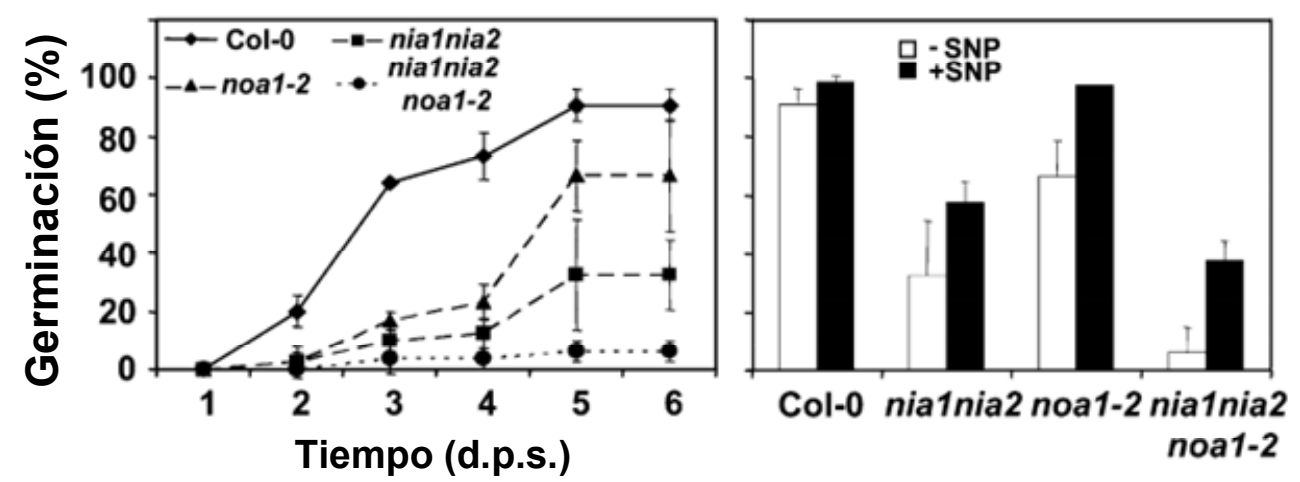

B
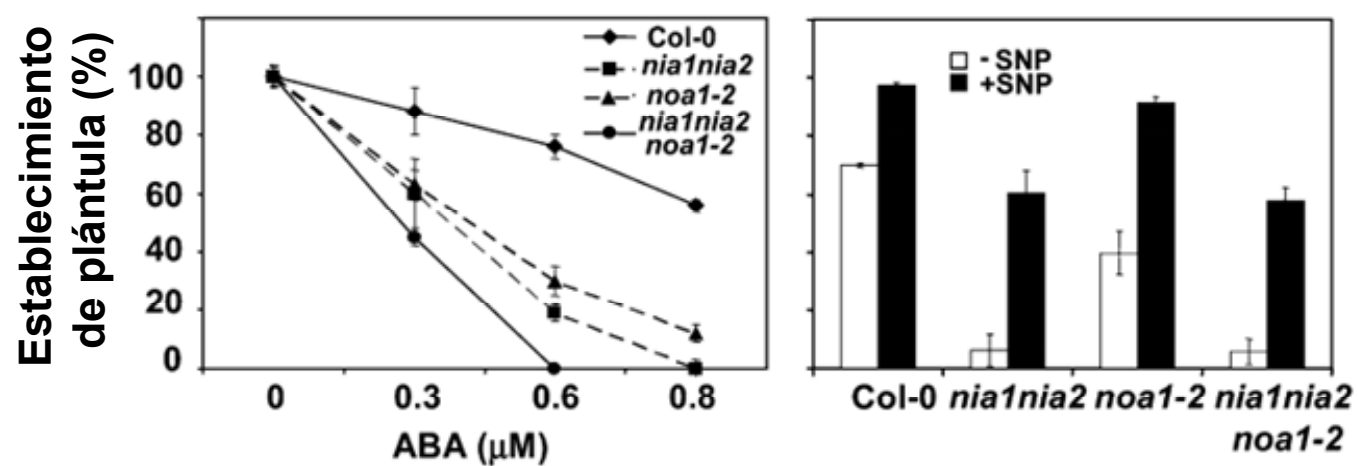

Figura 12. Los mutantes deficientes en la producción de NO son hipersensibles a ABA.

A. Porcentaje de germinación de semillas frescas (durmientes) de los diferentes mutantes sembradas sin estratificación en placas MS a lo largo de los días post siembra. (d.p.s). Ensayos realizados en presencia (+SNP, barras negras) o en ausencia (-SNP, barras blancas) de NO liberado por una solución de $100 \mu \mathrm{M}$ SNP (derecha). La germinación se contabilizó a los 5 d.p.s. y se representa la media \pm error estándar de tres experimentos independientes con al menos 200 semillas por experimento. B. Porcentaje de plántulas con cotiledones verdes y expandidos en medio MS suplementado con diferentes concentraciones de ABA. Las semillas se sembraron tras estratificarlas tres días a $4{ }^{\circ} \mathrm{C}$ y el establecimiento se determinó a 12 d.p.s. (izquierda). Ensayos similares realizados en medio MS con 0,5 $\mu \mathrm{M}$ ABA en presencia (+SNP, barras negras) o ausencia (-SNP, barras blancas) de NO liberado de una solución $100 \mu \mathrm{M}$ SNP (derecha). Los valores representan la media \pm error estándar.

Ya que el ABA se mantiene a niveles altos en semillas durmientes y mutantes hipersensibles a esta hormona tienen una dormición muy acusada (Finkelstein et al., 2008), nos preguntamos si la reducida germinación de semillas durmientes de los mutantes NO deficientes se 
debía a una mayor sensibilidad a esta hormona. Se realizaron ensayos de sensibilidad a ABA contabilizando el establecimiento de plántulas de los diferentes genotipos en concentraciones crecientes de ABA. Todos los mutantes deficientes en NO mostraron hipersensibilidad a ABA en este tipo de ensayo con una hipersensibilidad más acentuada en el caso del triple mutante (Fig. 12B). A una concentración de $0,6 \mu \mathrm{M}$ de ABA, alrededor del $80 \%$ de las semillas silvestres y solo un $35 \%$ y un $20 \%$ de las semillas de noal-2 y nialnia2, respectivamente, presentaban cotiledones verdes y expandidos (Fig. 12B). Además, las semillas del triple mutante mostraban un $100 \%$ de inhibición del establecimiento a la misma concentración de ABA (Fig. 12B), sugiriendo que las rutas de síntesis de NO mediadas por NIA/NR y AtNOA1 son aditivas en términos de la inhibición del establecimiento de plántula producido por el ABA. De nuevo, la aplicación de NO exógeno, alivió la inhibición del establecimiento de plántula ejercido por el ABA (Fig. 12B, panel derecho). Esta reversión fue casi total en el caso del mutante noal-2 y suficiente para incrementar el establecimiento del 10\% al 60\% en los mutantes nia 1,2 y nial,2noal-2 (Fig. 12B, panel derecho).

Este efecto aditivo se observó también cuando se realizó el mismo tipo de ensayo, contabilizando en este caso la germinación de las semillas silvestres y mutantes con el tiempo en presencia de 0,5 $\mu \mathrm{M}$ ABA (Fig. 13). Debido al conocido papel que ejerce el contenido en azúcares sobre la germinación y la señalización de ABA (revisado por (Graham 2008)) llevamos a cabo ensayos de germinación y establecimiento de plántula en medios suplementados con ABA en presencia o ausencia de sacarosa en el medio (Fig. 14). Sin embargo, no encontramos ningún efecto diferencial en la inhibición de la germinación o establecimiento ejercido por el ABA entre los mutantes deficientes en NO en medios con o sin sacarosa (Fig. 14).
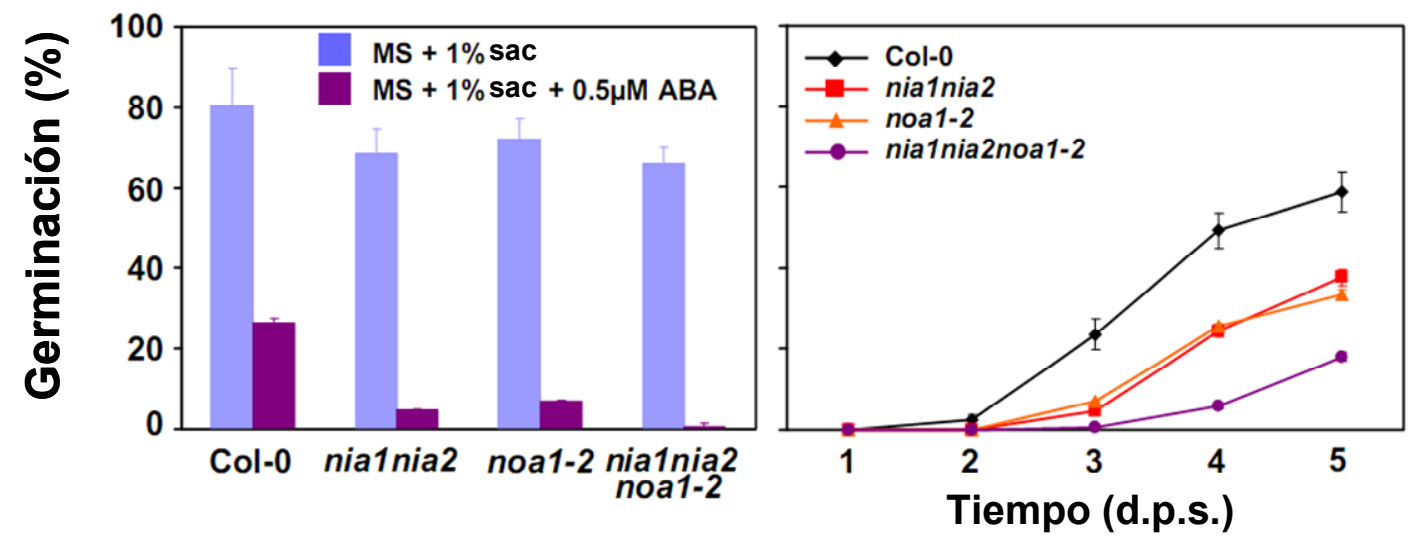

Figura 13. Los mutantes deficientes en la producción de NO son hipersensibles al ABA en germinación.

Germinación 3 días post siembra de semillas estratificadas de los diferentes mutantes en ausencia (barras azules) o presencia (barras violetas) de $0,5 \mu \mathrm{M}$ ABA (izquierda). La geminación de las mismas semillas en presencia de $0,5 \mu \mathrm{M}$ ABA fue contabilizada durante 5 días consecutivos (derecha). Los valores son media \pm desviación estándar. 

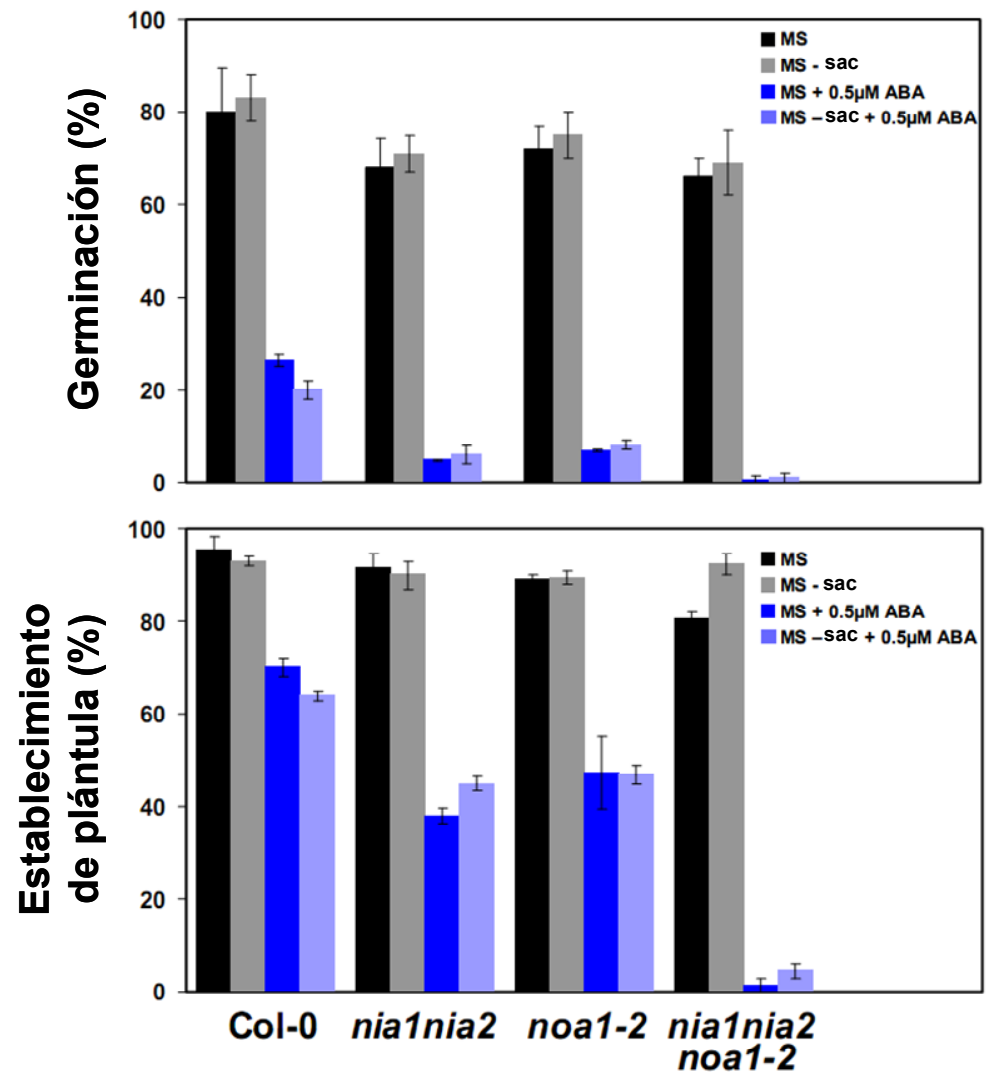

Figura 14. El contenido en sacarosa no afecta la sensibilidad a ABA de los mutantes deficientes en la producción de NO.

Las semillas de los diferentes genotipos se estratificaron y sembraron en los medios indicados y el \% de germinación y establecimiento determinado 3 ó 12 días tras la germinación, respectivamente. Los valores representan media \pm desviación estándar. sac, sacarosa $1 \%$.

Ya que la inhibición de la germinación ejercida por estrés osmótico es un proceso dependiente de ABA, procedimos a evaluar, en que medida, la deficiencia en NO puede alterar la germinación en un medio suplementado con $\mathrm{NaCl}$ o Manitol. La tabla I muestra que las semillas de los mutantes deficientes en NO son más sensibles a la inhibición de la germinación mediada por estrés osmótico que las semillas silvestres, siendo las semillas de los mutantes nialnia2 y nialnia2noal-2 más sensibles que las semillas del mutante noal-2 (Tabla I).

Tabla I. Efecto del tratamiento con sal o manitol en la germinación de semillas silvestres y de mutantes deficientes en NO.

\begin{tabular}{lcccc}
\hline & Col-0 & nialnia2 & noal-2 & nial,2noal-2 \\
\hline & & & & \\
Control & 100 & $96 \pm 2$ & 100 & $96 \pm 3$ \\
Manitol & $77.97 \pm 2.67$ & $15.1 \pm 0.94$ & $51.98 \pm 1.19$ & $14.13 \pm 2.05$ \\
$\mathrm{NaCl}$ & $50.77 \pm 6.88$ & $1.94 \pm 0.99$ & $14.64 \pm 4.81$ & 0 \\
& & & & \\
\hline
\end{tabular}


Semillas de los mutantes deficientes en NO y de plantas silvestres se sembraron en medio MS con $1 \%(\mathrm{p} / \mathrm{v})$ sacarosa (Control) o en el mismo medio suplementado con $150 \mathrm{mM} \mathrm{NaCl}$ o $250 \mathrm{mM}$ Manitol. Los valores de porcentaje representan la media de cuatro experimentos independientes \pm error estándar.

\section{Análisis de la expresión de genes de respuesta a ABA en los mutantes deficientes en NO}

Los mutantes hipersensibles a ABA presentan una expresión elevada de los genes de respuesta a ABA (Saez et al., 2006) Rubio et al., 2009). Para determinar si los mutantes deficientes en NO presentan este mismo fenotipo molecular, se monitorizó mediante PCR cuantitativa la expresión de los genes inducibles por ABA, RD29b (Yamaguchi-Shinozaki y Shinozaki 1993) y RAB18 (Jeannette et al., 1999). La tabla II muestra que todos los mutantes NO deficientes presentan alrededor de dos veces más expresión de estos genes que las plantas silvestres. Además, tras tratar con $\mathrm{ABA}$, el triple mutante mostró 2 veces más inducción de estos genes que el silvestre (Tabla II). Sin embargo, mientras que los mutantes nialnia2 y noal-2 presentan unas inducciones mayores que las del silvestre, no son tan altas como las del mutante nialnia2noal-2 (Tabla II). Estos datos sugieren que la modulación por NO de la sensibilidad a ABA no es exclusiva de las semillas pudiendo ser también funcional en plántulas o en plantas adultas

Tabla II. Niveles de expresión de genes de respuesta a ABA en plántulas de los mutantes deficientes en NO.

\begin{tabular}{cccccc}
\hline Tratamiento & Gen & \multicolumn{3}{c}{ Genotipo } \\
\cline { 3 - 6 } & & Col-0 & nialnia2 & noal-2 & nialnia2noal-2 \\
\hline Control & & & & & \\
& $R D 29 b$ & 1 & $2.39 \pm 0.44$ & $2.10 \pm 0.45$ & $2.65 \pm 0.37$ \\
& $R A B 18$ & 1 & $1.74 \pm 0.14$ & $1.95 \pm 0.42$ & $2.17 \pm 0.21$ \\
ABA & & & & & \\
& $R D 29 b$ & 1 & $1.31 \pm 0.05$ & $1.25 \pm 0.10$ & $2.33 \pm 0.15$ \\
& $R A B 18$ & 1 & $1.65 \pm 0.25$ & $1.63 \pm 0.15$ & $2.05 \pm 0.20$ \\
\hline
\end{tabular}

Los valores son media de tres réplicas biológicas independientes \pm error estándar y se muestran como valores relativos a aquellos detectados en el silvestre Col-0. Los valores han sido normalizados con los de la Actina 2/8. 


\section{La deficiencia en NO confiere resistencia a la deshidratación}

Ya que las plantas deficientes en la producción de NO muestran hipersensibilidad al ABA, analizamos la posibilidad de que dichas plantas tuvieran un fenotipo de resistencia a la deshidratación dependiente de ABA. Plantas silvestres y diferentes mutantes deficientes en NO se sometieron a déficit hídrico dejando de regar durante 28 días. Tras dicho periodo de sequía, las plantas deficientes en NO mostraron una clara resistencia a la deshidratación, con un efecto muy marcado en plantas nialnia2noal-2 (Fig. 15). Mientras que las plantas silvestres mostraron efectos de deshidratación dramáticos, las plantas del triple mutante permanecieron verdes y con apenas síntomas evidentes de deshidratación (Fig. 15A). La pérdida de peso debida a la transpiración fue significativamente más lenta en los mutantes que en las plantas silvestres, siendo las plantas del triple mutante las que mostraban una pérdida de peso más baja de acuerdo con el fenotipo de extrema resistencia a la deshidratación observado (Fig. 15A,B). Por otro lado, mientras que sólo el $42 \%$ de las plantas silvestres sobrevivieron al tratamiento de sequía tras restaurar el riego, el $100 \%$ de las plantas mutantes sobrevivieron (Fig. 15A).

A

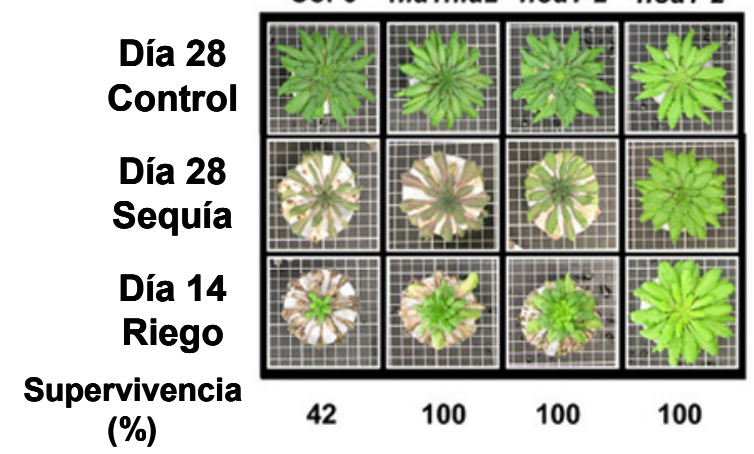

B

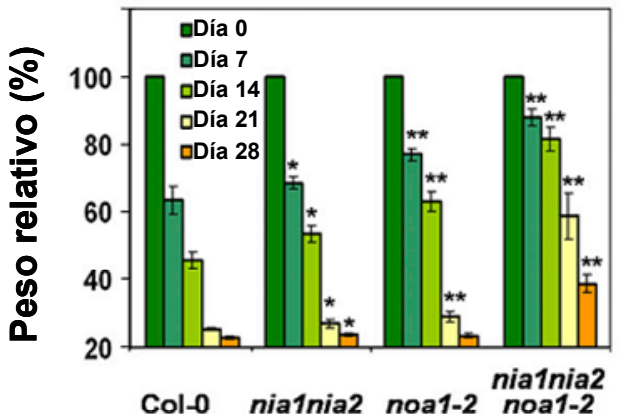

C

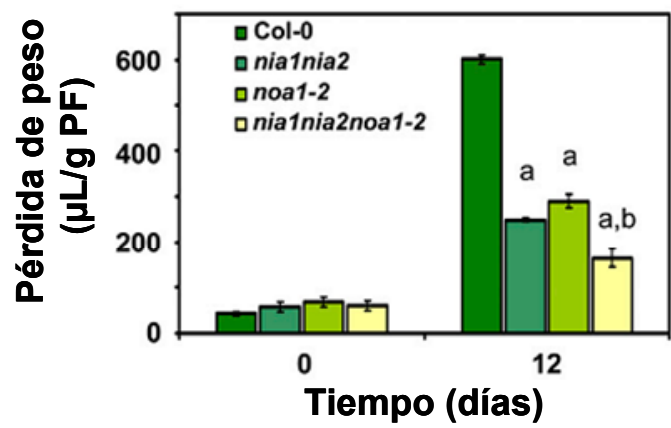

Figura 15. Resistencia al déficit hídrico de los mutantes deficientes en NO.

A. Apariencia de los diferentes genotipos crecidos en días cortos, 28 días después de dejar de regar y 14 días tras restaurar el riego. La supervivencia se estimó como el porcentaje de plantas que desarrollaron nuevas hojas 14 días después de restaurar el riego. Las plantas (10 plantas por experimento y tres experimentos independientes) se cultivaron en sustrato Jiffy 7 bajo condiciones de días cortos. B. Pérdida en peso fresco relativo de las mismas plantas que en A. El peso total se midió antes y cada 7 días después de cesar el riego hasta el día 28. C. Cuantificación de la pérdida de agua por evapotraspiración en plantas dejadas de regar durante 12 días. Los datos son la media del agua perdida en 10 hojas de 10 plantas diferentes. a, p-valor $<0,001$ comparando el silvestre con los demás genotipos. b, p-valor $<0,005$ comparando nialnia2 y noal-2 con nialnia2noal-2; valores obtenidos mediante test-t. Se presentan las medias \pm error estándar. ${ }^{*}$, p-valor $<0,05 ; * *$, p-valor $<0,005$ mediante test-t. 
Además, se realizó un experimento detallado de pérdida de agua comparando el peso fresco de hojas deshidratadas y turgentes de plantas sometidas a un tratamiento de deshidratación tal y como ha sido previamente descrito (Sáez et al., 2006). Bajo estas condiciones experimentales, noa1-2 y nialnia2 mostraron una reducida pérdida de agua, reteniendo alrededor de dos veces más agua que las hojas silvestres (Fig. 15C). Este fenotipo fue incluso más fuerte en el caso de las hojas de nialnia2noal-2, las cuales retuvieron 4 veces más agua que las plantas silvestres bajo el mismo periodo de deshidratación (Fig. 15C). Estos resultados manifiestan de nuevo el papel aditivo de las rutas NR/NIA y AtNOA1 en la resistencia a la deshidratación, lo que esta de acuerdo con la aditiva hipersensibilidad a ABA de los diferentes mutantes deficientes en NO descrita anteriormente.

Para estudiar si la resistencia a la sequía de las plantas NO deficientes es debida a efectos directos en la regulación del cierre estomático, procedimos a medir la apertura de estomas de plantas silvestres y nialnia2noal-2 en diferentes condiciones y mediante tres técnicas independientes pero complementarias. En primer lugar, se analizó el cierre estomático tras tratar con ABA midiendo la apertura de los estomas directamente. Tras tratar plántulas con $50 \mu \mathrm{M}$ ABA los estomas del mutante nialnia2noal-2 estaban más cerrados que los de plántulas silvestres, sugiriendo que los estomas de nialnia2noal-2 se cierran más eficientemente en respuesta a ABA (Fig. 16A,B). A concentraciones saturantes de $150 \mu \mathrm{M}$ ABA, los estomas de plantas silvestres y mutantes se comportan igual (Fig. 16A, B). De forma complementaria, los estomas de nialnia2noal-2 se cerraron más que los silvestres tras el mismo tratamiento de deshidratación (Fig. 16C). Ya que el ABA regula también la apertura de los estomas por luz (Roelfsema y Hedrich 2005), se analizó este proceso en plántulas silvestres y nialnia2noal-2. Los estomas del triple mutante se abren en respuesta a la luz al igual que los estomas silvestres (Fig. 16D). Esta apertura estomática se inhibió por $\mathrm{ABA}$ en plántulas silvestres pero el efecto fue significativamente más acusado en el triple mutante (Fig. 16D), lo que, de nuevo, apoya la hipersensibilidad al ABA mostrada por nialnia2noal-2. Además, la inhibición de la apertura estomática se previno mediante un tratamiento con el quelante de calcio permeable BAPTA/AM o el secuestrador de NO, cPTIO, en plantas silvestres pero no en el mutante nialnia2noal-2 (Fig. 16D). 
A

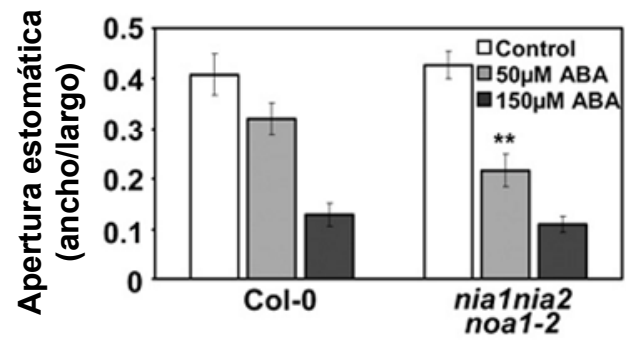

B
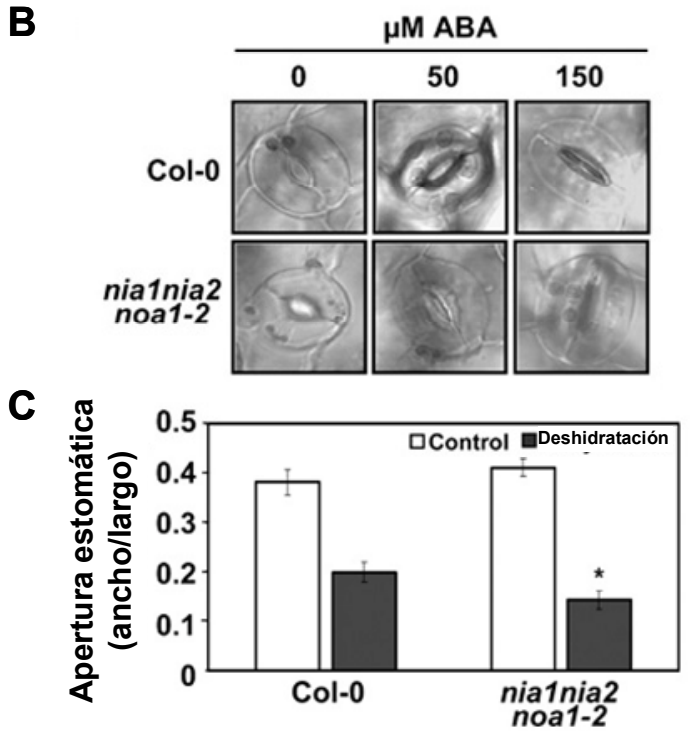

D

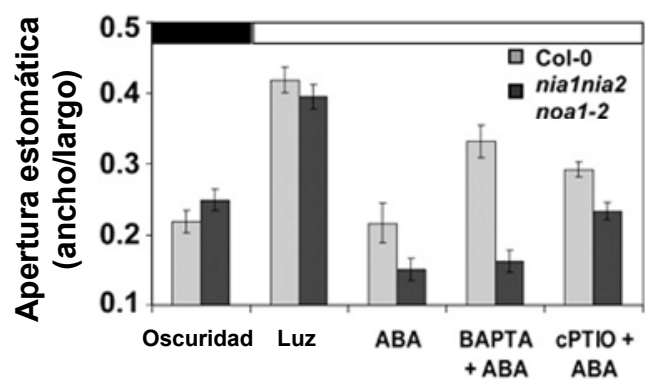

Figura 16. El mutante nia1nia2noa1-2 presenta una apertura estomática reducida.

A. El cierre estomático mediado por ABA en los diferentes genotipos fue testado en plántulas con los estomas pre-abiertos durante 2,5 horas bajo iluminación, y después incubados durante 2,5 horas en las concentraciones de ABA indicadas. Los datos representan la media \pm error estándar de 40 estomas medidos por experimento. El experimento se repitió dos veces con los mismos resultados. B. Imágenes de microscopía confocal mostrando estomas de diferentes genotipos en diferentes condiciones usados para la cuantificación de A. C. Apertura estomática en condiciones control (barras blancas) o de deshidratación (barras grises). La deshidratación se llevó a cabo colocando las plántulas durante 5 minutos en una cabina de flujo. D. Inhibición por ABA de la apertura estomática inducida por luz. Las plántulas se mantuvieron en oscuridad en tampón de apertura $2,5 \mathrm{~h}$ y después se trataron $0,5 \mathrm{~h}$ con $50 \mu \mathrm{M}$ ABA, $250 \mu \mathrm{M}$ BAPTA-AM o $250 \mu \mathrm{M}$ cPTIO como se indica en Materiales y Métodos, pasándolas a luz posteriormente. La apertura estomática se midió justo antes de la transferencia a luz (Oscuridad) o 2,5 h tras pasar las plántulas a luz. *, p-valor $<0,05 ; * *$, p-valor $<0,005$ calculado mediante test-t.

Para confirmar los resultados obtenidos, realizamos medidas de la apertura estomática utilizando un método no invasivo para minimizar la producción de NO derivada del daño mecánico. Para ello, analizamos la conductancia estomática que era menor en las plantas nialnia2no1-2 que en las silvestres tras ser sometidas a 7 y 14 días de ausencia de riego (Fig. 17A). Además, como la medida del potencial hídrico puede ser utilizado para monitorizar el estatus hídrico de la plantas, debido al menos en parte al cierre estomático, procedimos a medir el potencial hídrico de hojas (LWP, del inglés Leaf Water Potential) de plantas silvestres y nialnia1noa1-2. Después de 7 días tras dejar de regar las plantas, no se observó ninguna diferencia significativa en LWP de acuerdo con la ausencia de síntomas de deshidratación obvios en las plantas (Fig. 17B). Sin embargo, tras 14 días de sequía, las plantas silvestres mostraron tanto un fenotipo claro de deshidratación como una pronunciada bajada de su potencial hídrico (Fig. 17B). En cambio, sólo se observó una pequeña bajada del LWP en las plantas nialnia2noal-2, 
correlacionándose muy bien con la ausencia de un fenotipo debido al déficit hídrico en estas plantas (Fig. 17B).

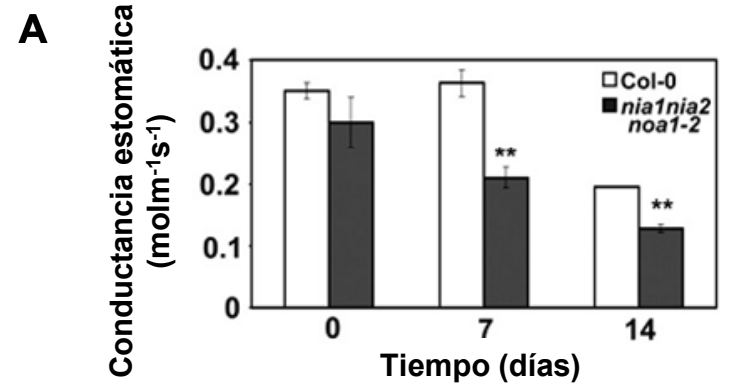

$\mathbf{B}$

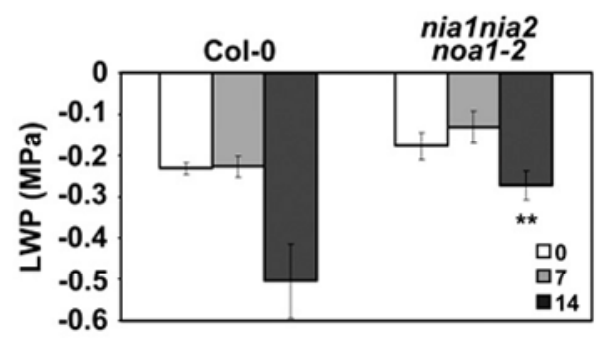

C

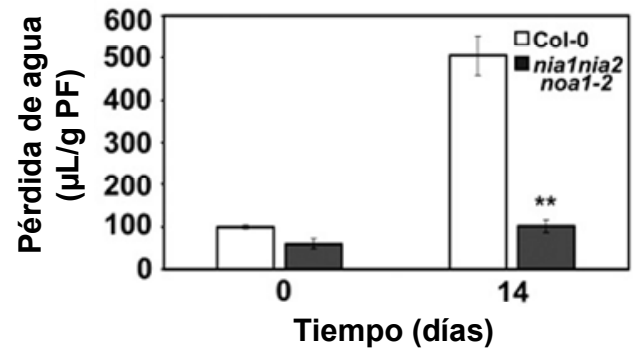

Figura 17. Conductancia estomática, potencial hídrico (LWP) y pérdida de peso de plantas silvestres y nia1nia2noa1-2 tras diferentes periodos de sequía.

A. Conductancia estomática de hojas de los diferentes genotipos tras diferentes tiempos después de cesar el riego. Se muestran las medias de 18 réplicas \pm error estándar. El experimento se repitió dos veces con resultados similares. B. LWP de plantas dejadas de regar durante los tiempos indicados. Los valores representan la media \pm desviación estándar de seis réplicas independientes. C. Ensayo de pérdida de peso (media \pm desviación estándar) realizado sobre las mismas plantas usadas en A. **, p-valor $<0,001$ mediante test-t.

\section{DISCUSIÓN}

El NO ejerce diferentes funciones en diferentes procesos durante todo el ciclo vital de las plantas. Si bien su papel en la defensa frente a diferentes interacciones planta-patógeno ha sido descrito en profundidad (Leitner et al., 2009), su papel frente a otros tipos de estrés está menos documentada y se sigue estudiado activamente en la actualidad (Chehab et al., 2009; Molassiotis et al., 2010; Ramirez et al., 2010). Existe un claro papel del NO en la regulación de la germinación (Beligni y Lamattina, 2000) pero no ha sido hasta hace unos pocos años que se ha determinado que este papel se lleva a cabo mediante su interacción con una de las hormonas más relacionadas con la respuesta a estrés, en concreto a estrés de tipo abiótico, como el ABA (Bethke et al., 2004b; Bethke et al., 2006a; Bethke et al., 2007). Sin embargo, muchos de los trabajos relacionando en ABA y el NO han sido llevados a cabo mediante la aplicación de compuestos químicos que estimulan o reprimen la producción de NO o mediante donadores o secuestradores de NO sintetizados en laboratorio (Beligni y Lamattina 2000; Bethke et al., 2004b; Bethke et al., 2006a; 
Bethke et al., 2007). Son muy pocos los trabajos que han estudiado la regulación que ejerce el NO en procesos relacionados con el ABA utilizando mutantes en la síntesis de NO. En este capítulo, hemos descrito el papel de cada una de las principales vías enzimáticas de síntesis de NO, la dependiente de la actividad AtNOA1 y la dependiente de la actividad NR/NIA, en la interacción con el ABA en procesos como la dormición, la germinación y la resistencia a la deshidratación.

De acuerdo con el papel propuesto del NO disminuyendo la sensibilidad a ABA en la germinación (Bethke et al., 2006a), las semillas de los mutantes NO deficientes fueron más durmientes y mostraron una mayor sensibilidad al ABA en la inhibición de la germinación. Este efecto fue más severo en el caso de las semillas del mutante nialnia2noal-2 que en sus genotipos parentales, sugiriendo que hay una correlación entre los niveles endógenos de NO y la sensibilidad a ABA. De acuerdo con esto, los mutantes deficientes en NO presentaron niveles elevados de genes de la respuesta a ABA, como $R A B 18$ y $R D 29 b$.

La alterada sensibilidad a ABA es probablemente la causa de la resistencia a la deshidratación que tienen las plantas deficientes en NO, en especial las plantas nialnia2noal-2. El ABA promueve el cierre de estomas y previene su apertura (Neill et al., 2008). El NO ha sido descrito como un componente de la ruta de señalización del ABA que regula el cierre estomático (Desikan et al., 2002; Guo et al., 2003; Garcia-Mata y Lamattina 2007). Debido a que las plantas deficientes en NO son resistentes a la sequía, la reducida pérdida de agua de los mutantes NO deficientes puede ser debida a una hipersensibilidad a ABA, dando lugar a una mayor inhibición de la apertura y un cierre más eficiente por ABA de los estomas. De hecho, hemos encontrado una hipersensibilidad del mutante nialnia2noal-2 en el cierre de estomas estimulado por deshidratación o el tratamiento con ABA, así como en la inhibición por ABA de la apertura de estomas estimulada por la luz. Consecuentemente, las hojas de las plantas nialnia2noal-2 muestran una menor conductancia estomática, una drástica reducción de la pérdida de agua por transpiración y la ausencia de una alteración significativa del potencial hídrico de las hojas tras un periodo de ausencia de riego. Estos datos sugieren que la regulación de la apertura estomática mediada por $\mathrm{ABA}$ no requiere necesariamente de la biosíntesis de novo de $\mathrm{NO}$ a través de las rutas NR/NIA o AtNOA1. Estos resultados contrastan con los de Desikan et al. (2002) que propone que la vía de síntesis dependiente de NR/NIA es esencial para el cierre estomático mediado por ABA. Sin embargo, tal y como describen en su trabajo, los autores no pudieron detectar un fenotipo de marchitamiento en el mutante nialnia 2 tal y como sería de esperar de una planta que no puede cerrar los estomas en respuesta a ABA (Desikan et al., 2002). Este hecho sugiere que el ABA puede cerrar los estomas de manera independiente a NO. Esto, esta de acuerdo también con el mayor cierre estomático detectado en el doble mutante nialnia2 o en los mutantes sencillos nial o nia2 sometidos a deshidratación (Ribeiro et al., 2009). Además, la inhibición de la apertura de los estomas mediada por ABA no está afectada en el mutante nialnia2noal-2 de acuerdo con los datos publicados para plantas nialnia2 (Desikan et al., 2002). Así, nuestros datos sugieren que los 
mutantes deficientes en NO presentan un cierre estomático y una inhibición de la apertura más eficientes debido a su hipersensibilidad a ABA. Este proceso esta mediado esencialmente por una ruta independiente de la biosíntesis de novo de $\mathrm{NO}$, tal y como se demuestra por la ausencia de producción de NO en estomas de nialnia2noal-2 que se cierran perfectamente en respuesta a ABA (Fig. 18,16).

\section{Col-0}
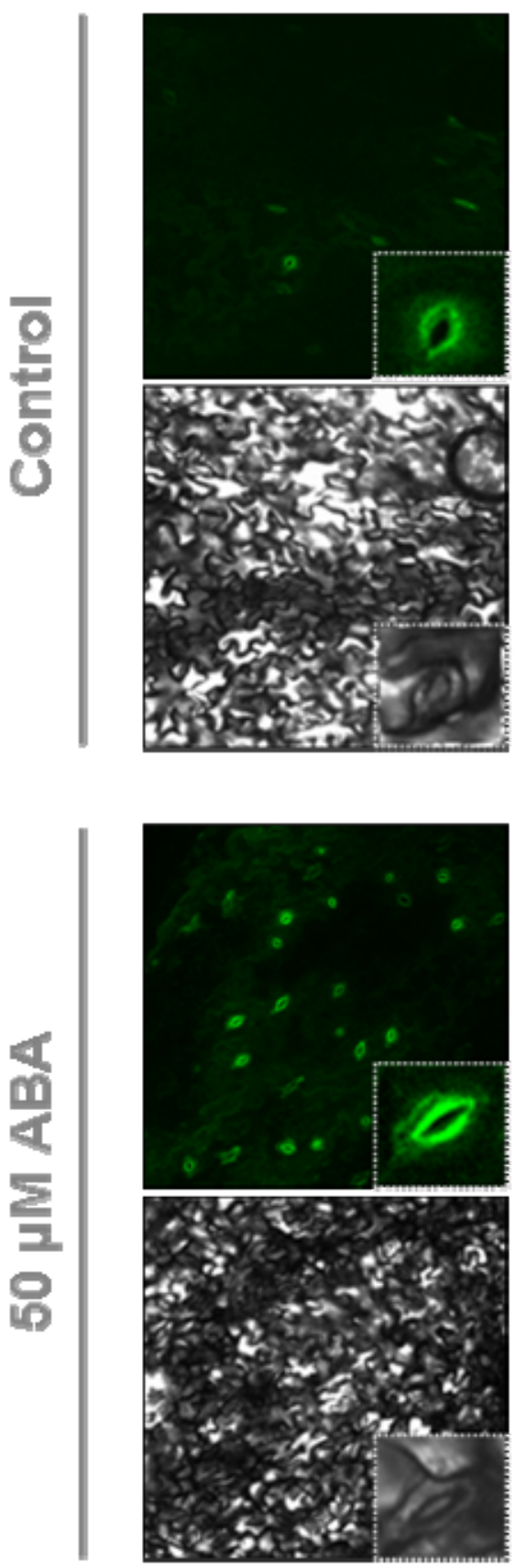

\section{nia1nia2noa1-2}
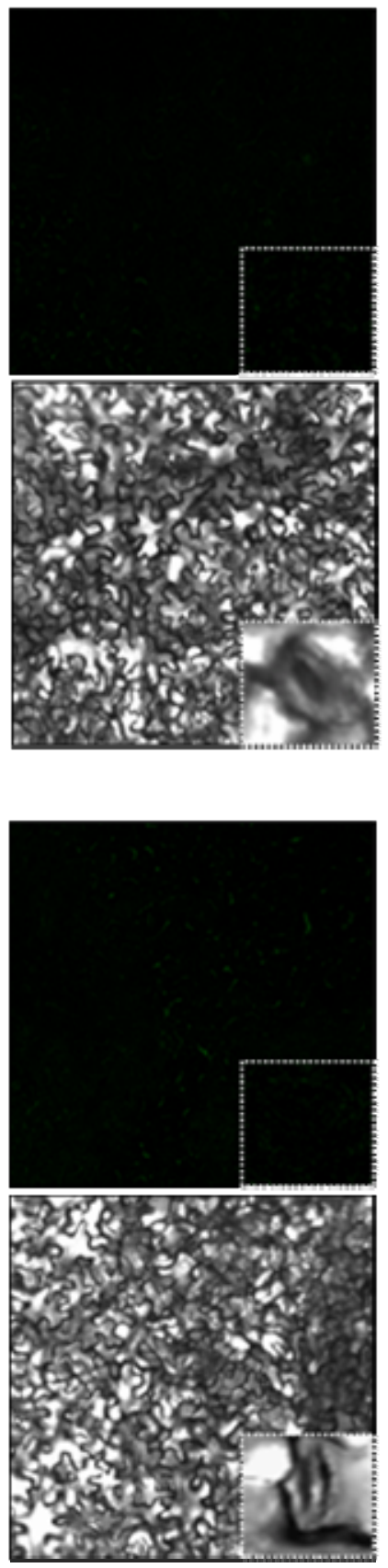

Figura 18. Acumulación de NO en células de guarda.

Se muestran imágenes de hojas tratadas o no con $50 \mu \mathrm{M}$ ABA 30 min, teñidas con DAF-FM DA, obtenidas con el microscopio confocal. Las ampliaciones representan el mismo estoma bajo campo oscuro (arriba) o campo claro (abajo). 
Además, hemos comprobado que la aplicación de un secuestrador de NO, como el cPTIO, previene la inhibición de la apertura de estomas que ejerce el ABA, aunque no totalmente, tal y como se había descrito previamente (García-Mata y Lamattina, 2007; Ribeiro et al., 2009), mientras que la ausencia constitutiva de NO, en las plantas nialnia2noal-2 no lo previno. Por otro lado, aunque se ha descrito que cambios endógenos en los niveles de calcio juegan un papel importante en la inhibición de la apertura estomática por ABA (Roelfsema y Hedrich, 2005) y nuestros datos apoyan esto en plantas silvestres, hemos encontrado que este proceso es independiente de calcio en el mutante nialnia2noal-2. Así, parece que la reducida acumulación de NO en el triple mutante hace que los estomas no respondan al tratamiento con el quelante de calcio, BAPTA/AM (Fig. 16C). Entonces, se puede postular que el NO es necesario para la señalización de ABA dependiente de calcio, tal y como se ha descrito previamente ( $\mathrm{Li}$ et al., 2009a; Dubovskaya et al., 2011). Sin embargo, mediante los experimentos realizados no podemos discriminar si el papel del NO tendría lugar por encima o por debajo de la liberación de calcio. De todas formas, el papel positivo del calcio en el cierre de estomas es difícilmente conciliable con el papel negativo del NO si estos dos segundos mensajeros operan en la misma ruta. Así, el fenotipo de insensibilidad al quelante de calcio en las plantas NO deficientes se puede explicar de una manera más sencilla a través de la hipersensibilidad a ABA de estas plantas. Además, esta hipersensibilidad, debe tener lugar mediante elementos de la señalización de ABA independientes de calcio, como pueden ser las quinasas independintes de calcio, cuyo ejemplo más claro es OST1 (Mustilli et al., 2002; Merlot et al., 2002). Si esta hipótesis es cierta, esperaríamos una mayor expresión/actividad de OST1 (u otras quinasas independientes de calcio), en el triple mutante que podría explicar su hipersensibilidad a ABA en el cierre estomático, y que ésta sea independiente de calcio.

Este trabajo, propone que las vías NR/NIA y AtNOA1 contribuyen mayoritariamente a la producción de NO tras la aplicación de ABA en Arabidopsis. Varios fenotipos relacionados con la respuesta a ABA encontrados en las plantas deficientes en NO indican un papel negativo del NO en la regulación de la sensibilidad a ABA. Así, en plantas silvestres, el ABA promueve la síntesis de NO a través de las rutas NR/NIA y AtNOA1, que modulará negativamente la respuesta a ABA, probablemente para evitar una respuesta exagerada que podría ser perjudicial para la planta (Fig. 19). En condiciones donde la producción de NO dependiente de ABA esta comprometida, las células vegetales no disponen de este freno a la respuesta a $\mathrm{ABA}$, así que la respuesta es más fuerte, lo que correlacionaría muy bien con una potenciación de las respuestas mediadas por ABA en el triple mutante (Fig. 19). En el laboratorio estamos interesados en identificar las dianas moleculares responsables de esta mayor sensibilidad al ABA y, por ende, en la regulación cruzada ABA-NO en los procesos de germinación y cierre estomático. Si las dianas del NO son las 
fosfatasas de tipo $2 \mathrm{C}$ o los propios receptores del $\mathrm{ABA}$ es una pregunta que requiere de más trabajo que se esta realizando actualmente.

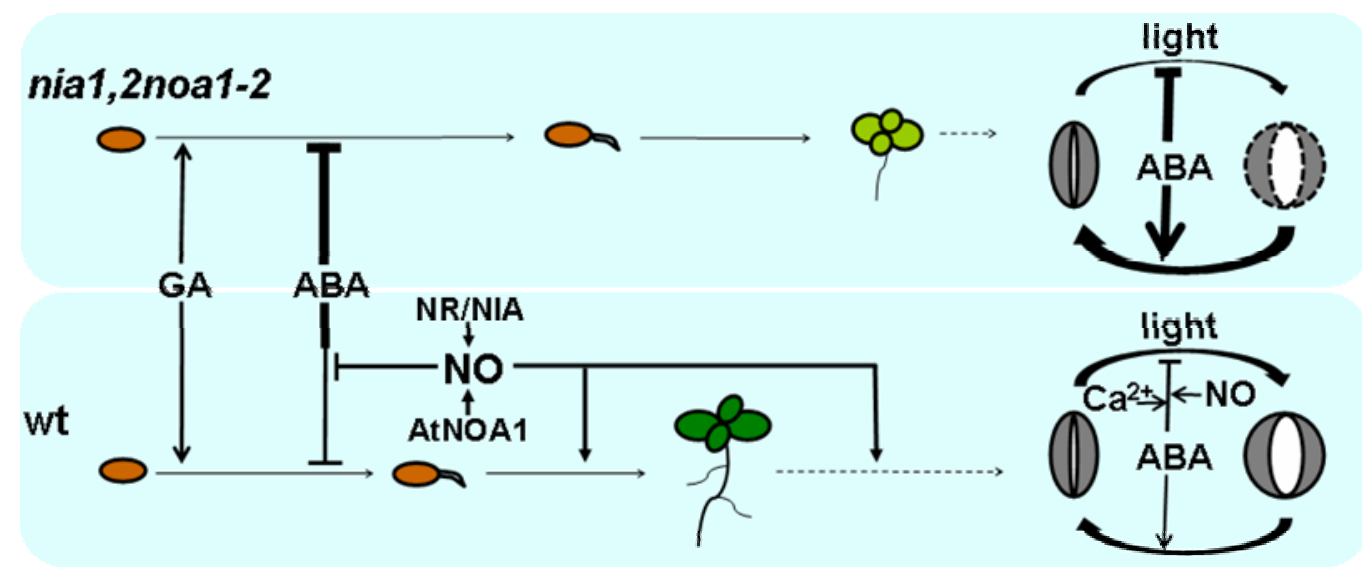

Figura 19. La deficiencia en NO resulta en una sensibilidad incrementada al ABA durante todo el desarrollo.

El NO producido por las vías dependientes de la NR/NIA y AtNOA1 regula la germinación, el desarrollo postgerminativo y el cierre de estomas a través de la modulación de la sensibilidad a ABA. Las flechas y las líneas romas indican efectos o positivos, respectivamente. El grosor de las líneas es proporcional a la magnitud del efecto regulatorio en cada caso. 
CAPÍTULO 3: INTERACCIÓN NO-GIBERELINAS EN EL DESARROLLO REGULADO POR LUZ 


\section{INTRODUCCIÓN}

Uno de los primeros estímulos que debe interpretar una planta tras germinar es la presencia/ausencia de luz y su dirección para crecer hacia ella. Tras la germinación, las semillas, en condiciones naturales, se pueden encontrar con dos escenarios: el primero, donde la semilla después de la dispersión ha quedado enterrada bajo el suelo, y un segundo escenario, donde la semilla se encuentra en la superficie. En el primer caso, debido a la falta de luz, la semilla, una vez germinada, activa rápidamente la elongación y el crecimiento celular para alcanzar la superficie donde la fuente de luz activará su metabolismo autótrofo. Este tipo de crecimiento se estimula por la falta de luz y se caracteriza por una elongación muy rápida del hipocotilo, unos cotiledones cerrados y no expandidos, la presencia de una estructura en forma de gancho que protege el meristemo, la ausencia de clorofilas y la baja expresión de los genes de respuesta a luz (Alabadi et al., 2004). En el segundo caso, las plantas no necesitan acelerar la elongación de sus células en busca de la luz, así que utilizan su energía para expandir los cotiledones, acumular clorofilas y activar la expresión de genes que se regulan por luz, condiciones que le permiten consolidar el metabolismo autótrofo (Alabadí et al., 2004). Al desarrollo temprano que se da en ausencia de luz se lo conoce como escotomorfogénesis mientras que cuando el desarrollo tiene lugar en condiciones de iluminación el desarrollo es fotomorfogénico (Neff et al., 2000).

Las plantas requieren, por tanto, de una maquinaria que le permita discriminar entre la presencia o la ausencia de luz. Pero además, puesto que su supervivencia depende de la disponibilidad de luz, las plantas poseen un sistema de percepción de luz extremadamente sofisticado que les permite monitorizar continuamente las condiciones de luz haciendo pequeños ajustes fisiológicos y en el desarrollo para su propio beneficio (Mathews 2006). Este sistema de percepción de luz esta formado por diferentes fotorreceptores que han evolucionado para detectar las longitudes de onda de la luz en los rangos del UV/azul $(\approx 400 \mathrm{~nm})$ y del rojo/rojo lejano $(\approx$ 700nm) (Jiao et al., 2007; Kami et al., 2010). Existen cuatro grupos de fotorreceptores: los tres clásicos, donde se incluyen los fitocromos, los criptocromos y las fototropinas y un "nuevo" conjunto de receptores de luz azul (Zeitlupes, ZTLs), que son proteínas F-Box que contienen un dominio LOV (del inglés, Light-Oxygen-Voltage), así como repeticiones tipo Kelch (Moglich et al., 2010). Por último, recientemente se ha descrito una proteína rica en residuos de triptófano, UVR8, que podría actuar como un receptor de luz UV-B (Rizzini et al., 2011). Se ha postulado que esta proteína funciona de manera diferente a los fotorreceptores descritos anteriormente, siendo los residuos de triptófano de esta proteína los que ayudan a la percepción de la luz UV-B (Rizzini et al., 2011).

Dentro de los grupos de fotorreceptores, los fitocromos, que perciben la luz en la longitud de onda del rojo y el rojo lejano, están codificados, en Arabidopsis thaliana, por cinco genes (desde PHYA hasta PHYE). Éstos, regulan aspectos como la germinación, la fotomorfogénesis, la huida 
de la sombra, la floración y muchas otras respuestas adaptativas (Clack et al., 1994). Por otro lado, los criptocromos y las fototropinas, son receptores de luz azul. En Arabidopsis thaliana existen dos criptocromos convencionales CRY1 y CRY2 (Ahmad y Cashmore 1993; Lin et al., 1998) que regulan diferentes respuestas a la luz azul como la fotomorfogénesis y la floración, entre otras (Ahmad y Cashmore, 1993; Lin et al., 1998). Además, encontramos un tercer miembro de este grupo de fotorreceptores, CRY3, también llamado CRY-DASH (Drosophila, $\underline{\text { Arabidopsis, }}$ Synechicystis y $\underline{H}$ omo), con función todavía desconocida (Brudler et al., 2003; Kleine et al., 2003) aunque recientemente se le han atribuido funciones de reparación del DNA debidas a la iluminación con luz UV/azul (Huang et al., 2006; Selby y Sancar 2006; Pokorny et al., 2008). Las fototropinas, codificadas en Arabidopsis thaliana por los genes PHOT1 y PHOT2, son responsables del reconocimiento de la dirección de la luz azul (Christie et al., 1998; Jarillo et al., 2001b; Kagawa et al., 2004), y regulan principalmente los movimientos regulados por la luz como los fototropismos, el movimiento de los cloroplastos o la apertura de estomas, así como otras respuestas dependientes de la luz azul como la expansión de las hojas, la inhibición de la elongación del hipocotilo y la promoción del crecimiento bajo intensidades de luz débiles (Christie y Briggs 2001; Harberd 2006). Por último, existe una "nueva" familia de receptores de luz azul, denominados ZTLs, compuesta por tres miembros: ZTL1/ADO1/LKP1/FKL2 (del inglés ZEITLUPE1, ADAGIO1, LOV KELCH PROTEIN1 y FKF-LIKE 2) (Kiyosue y Wada 2000; Somers et al., 2000; Jarillo et al., 2001a), LKP2/ADO2 y FKF1/ADO3 (del inglés, FLAVINBINDIG KELCH DOMAIN F-BOX PROTEIN 1/ADAGIO 3) (Nelson et al., 2000; Schultz et al., 2001). Estas tres proteínas contienen un sitio de unión a mononucleótido de flavina (FMN) necesario para la absorción de luz azul (Imaizumi et al., 2003). Las proteínas ZTLs regulan el reloj circadiano, la floración y la señalización por luz azul (Mas et al., 2000; Schultz et al., 2001; Kiba et al., 2007).

Estos son los cuatro grupos fundamentales que forman parte de la maquinaria de percepción de la luz en las plantas, si bien se han descrito receptores para la luz verde y para la UV-B (Folta y Maruhnich 2007; Jenkins 2009; Rizzini et al., 2011).

Una vez se ha percibido la luz (calidad, dirección e intensidad) su información se tiene que transformar en ajustes en el crecimiento y desarrollo de la planta. En este proceso juegan un papel crucial las proteínas que interaccionan con los fotorreceptores (Bae y Choi 2008). Tomando como ejemplo el de los fitocromos, las proteínas que interaccionan con los fitocromos se encargan de controlar la localización de estos fotorreceptores (Hiltbrunner et al., 2005; Hiltbrunner et al., 2006), su acumulación (Seo et al., 2004; Mira-Rodado et al., 2007; Chen et al., 2010a), y la transmisión de la información aportada por la luz (Kim et al., 2003; Saijo et al., 2003; Seo et al., 2003; Bauer et al., 2004; Park et al., 2004; Jang et al., 2005). De las más de 20 proteínas que interaccionan con los fitocromos (Bae y Choi., 2008), cabe destacar el grupo de proteínas conocidas como factores que interaccionan con los fitocromos (del inglés Phytochrome-Interacting 
Factors, PIFs), que regulan multitud de respuestas dependientes de luz (Zhu et al., 2000; Shen et al., 2005; Oh et al., 2007), y COP1, un regulador clave de la fotomorfogénesis (Deng et al., 1991; Seo et al., 2003; Seo et al., 2004).

Las proteínas PIF (PIF1, PIF3, PIF4, PIF5, PIF6 y PIF7) forman parte de la familia de factores de transcripción bHLH (Heim et al., 2003; Toledo-Ortiz et al., 2003; Bae y Choi 2008) y se unen preferiblemente a cajas G (CACGTG) (Huq y Quail 2002), en los promotores de sus genes diana. Su función más estudiada es la inhibición de la fotomorfogénesis en oscuridad, siendo muy importantes en la promoción del crecimiento etiolado (Leivar y Quail 2011). Estos factores de transcripción no solo responden al estímulo lumínico, sino que también se regulan por el reloj circadiano (Yamashino et al., 2003; Kidokoro et al., 2009), teniendo también un papel importante en la respuesta adaptativa de las plantas frente a altas temperaturas (Koini et al., 2009; Stavang et al., 2009). Estas proteínas se regulan tanto a nivel transcripcional como post-transcipcional, de manera que son rápidamente degradadas en presencia de luz por el sistema ubiquitina-proteasoma (Al-Sady et al., 2006; Shen et al., 2007; Lorrain et al., 2008), aunque, conviene resaltar, que sus niveles no se ven reducidos por completo sino que existe una regulación fina para mantener niveles muy reducidos pero detectables de estas proteínas (Leivar y Quail, 2011). Así, una vez que estas proteínas interaccionan con el fitocromo en el núcleo, son fosforiladas por una quinasa todavía desconocida y marcadas con ubiquitina por una E3 ubiquitina ligasa también desconocida. Estas modificaciones promueven su posterior degradación por el proteasoma 26S, donde HEMERA, una proteína con homología a la proteína de unión a ubiquitina RAD23, juega un papel importante (Al-Sady et al., 2006; Shen et al., 2007; Lorrain et al., 2008, Chen et al., 2010). La interacción, fosforilación y degradación tiene lugar en unos complejos nucleares denominados "speckles", en un tiempo medio de tan solo 15-20 minutos (Chen et al., 2010; Leivar y Quail, 2011). Además, los niveles de las proteínas PIF vuelven de nuevo a sus niveles máximos en oscuridad, lo que permite un control sobre sus genes diana en las transiciones diarias de oscuridadluz (Nozue et al., 2007). El primer PIF identificado, PIF3, se identificó por su capacidad de interaccionar con el fitocromo B (Ni et al., 1998). Se sabe que PIF3 interacciona con la forma fotoactivada del fitocromo B mediante una secuencia conservada en los PIF denominada APB (del inglés, Active Phytochrome $\underline{B}$ Binding motif) aunque esta proteína, al igual que PIF1, puede interaccionar también con la forma foto-activada del fitoctomo A, mediante el motivo APA, lo que hace a estas dos proteínas diferentes del resto de PIFs (Khanna et al., 2004; Al-Sady et al., 2006). Para controlar la expresión de sus genes diana, los PIF pueden unirse a DNA tanto en forma de homo- como de hetero-dímeros (Castillon et al., 2007), siendo la formación de homodímeros la situación más generalizada (Castillon et al., 2007). Por otro lado, también pueden formar dímeros con otros factores de transcripción no pertenecientes al grupo de los PIF (Fairchild et al., 2000; Duek y Fankhauser 2003), e incluso con proteínas que no son factores de transcripción (de Lucas et al., 2008; Feng et al., 2008; Gallego-Bartolome et al., 2010), lo que resulta, en ocasiones, en la 
eliminación de su capacidad de activar/reprimir la transcripción (de Lucas et al., 2008; Feng et al., 2008; Hornitschek et al., 2009). La pérdida de función de diferentes PIFs resulta en un menor crecimiento del hipocotilo en condiciones de iluminación con luz roja, lo que se pensó que estaba causado por una hipersensibilidad a luz roja de estos mutantes (Al-Sady et al., 2008; Leivar et al., 2008a). De acuerdo con esto, se ha comprobado que PIF3 y PIF4 controlan negativamente los niveles de acumulación de PHYB mediante el papel de COP1, que actúa como E3 ubiquitin ligasa, etiquetando la forma fotoactivada del fitocromo B con ubiquitina y favoreciendo su posterior degradación por el proteasoma (Leivar et al., 2008a; Jang et al., 2010). Sin embargo, el análisis de diferentes combinaciones de mutantes pif, en especial, el cuádruple mutante piflpif3pif4pif5 (pifQ), ha establecido que los fenotipos de los mutantes sencillos pif, pueden ser explicados por el papel positivo que tienen los PIF sobre el desarrollo escotomorfogénico, más que por una hipersensibilidad a luz roja. Esto se pone claramente de manifiesto, con el fenotipo fotomorfogénico que presenta el mutante pifQ en oscuridad (Leivar et al., 2008b; Leivar et al., 2009).

Cuando la información ha sido transducida por los fotorreceptores y transmitida por las proteínas que interaccionan con ellos, las plantas modulan su crecimiento de manera acorde a la información percibida. Para ello, se modula tanto la síntesis como la señalización de algunas fitohormonas (Nemhauser 2008; Alabadi y Blazquez 2009; Lau y Deng 2010). Parece que las giberelinas, los brasinoesteroides y las auxinas son las hormonas que tienen un papel más importante en el control del desarrollo por luz aunque también se ha descrito un papel de otras hormonas como el etileno, las citoquininas y el ABA (Nemhauser 2008; Alabadí y Blázquez, 2009; Lau y Deng, 2010). De forma general, las hormonas que promueven el crecimiento como las giberelinas, los brasinoesteroides y las auxinas reprimen la fotomorfogénesis (Nemhauser et al., 2003; Alabadi et al., 2004; Cluis et al., 2004; Woodward y Bartel 2005; Achard et al., 2007; Lee et al., 2007). En relación con el control hormonal de la fotomorfogénesis, el papel de las giberelinas ha sido uno de los más estudiados y, recientemente, se ha descrito un modelo para la interacción entre las giberelinas y la luz en la regulación del desarrollo temprano de Arabidopsis thaliana (de Lucas et al., 2008; Feng et al., 2008).

Las giberelinas (GAs) son un conjunto de diterpenos tetracíclicos que se sintetizan por una compleja red de transformaciones químicas que tienen lugar entre los plastos, el retículo endoplasmático y el citosol (Buchanan et al., 2000), y constituyen una de las cinco hormonas clásicas (auxinas, citoquininas, etileno, ABA y GAs) (Buchanan et al., 2000). Las GAs controlan multitud de aspectos que influyen tanto en el crecimiento y el desarrollo como en la adaptación y la supervivencia a factores de estrés de tipo biótico y abiótico (Richards et al., 2001; Sun y Gubler 2004; Achard et al., 2006; Achard et al., 2008a; Achard et al., 2008b; Alabadi et al., 2008; de Lucas et al., 2008; Feng et al., 2008; Navarro et al., 2008). De las más de 100 giberelinas identificadas, solo $\mathrm{GA}_{1}$ y $\mathrm{GA}_{4}$ son las principales giberelinas activas (Schomburg et al., 2003), por 
lo que es necesaria una regulación muy fina para determinar los niveles de GAs activas en el momento y la localización precisa. Los puntos clave de su ruta de biosíntesis son los catalizados por las Giberelina-20-oxidasas (GA20ox) y las GA3ox (Chiang et al., 1995; Phillips et al., 1995), mientras que la desactivación de las mismas se produce principalmente por las GA2ox (Thomas et al., 1999; Schomburg et al., 2003; Rieu et al., 2008). En los últimos años, se han descrito dos nuevos mecanismos para la desactivación de las GAs activas mediante epoxidación (Zhu et al., 2006) o metilación (Varbanova et al., 2007). Los niveles de GAs activas se controlan por retroregulación de los genes de los últimos pasos de su síntesis o de su inactivación, de manera que mutantes deficientes en la síntesis o señalización de GAs tienen niveles elevados de los genes de su síntesis (GA20ox y GA3ox) y bajos de los de su inactivación (GA2ox), y viceversa (Yamaguchi 2008).

La señal comunicada por las GAs se percibe en la célula mediante la unión a su receptor soluble, GID1, descrito inicialmente en arroz, donde hay una única isoforma (Ueguchi-Tanaka et al., 2005) y, posteriormente, en Arabidopsis thaliana, donde hay tres isoformas diferentes, GID1a/GID1b/GID1c, con funciones tanto solapantes como independientes (Griffiths et al., 2006; Nakajima et al., 2006; Suzuki et al., 2009). Una vez que se ha establecido la unión GA-GID1, se reclutan a este complejo otros miembros de función muy relevante en la ruta de señalización de GAs, como son las proteínas DELLA (Griffiths et al., 2006; Willige et al., 2007). Una vez formado el complejo GA-GID1-DELLA, se facilita la unión de la F-Box SLY1, que forma parte del complejo SCF E3 ubiquitina-ligasa $\operatorname{SCF}^{\mathrm{SLY} 1 / \mathrm{GID} 2}$ (Sasaki et al., 2003; Griffiths et al., 2006; Willige et al., 2007). Ésta, promueve la ubiquitinación y posterior degradación de las proteínas DELLA por la vía dependiente del proteasoma 26S (Sasaki et al., 2003; Harberd 2003; Dill et al., 2004; Fu et al., 2004). Este proceso permite la liberación de la represión que ejercen las proteínas DELLA en el crecimiento (Harberd 2003), permitiendo así la respuesta a GAs.

Sin embargo, existe también una ruta de señalización de GAs independiente de la degradación de las proteínas DELLA, ya que el mutante slyl puede germinar en presencia de una alta acumulación de la proteína RGL2, la proteína DELLA responsable de la inhibición de la germinación (Ariizumi y Steber 2007). Además, la expresión ectópica de GID1 puede complementar el fenotipo de slyl/gid2 sin la necesidad de la degradación de proteínas DELLA (Ariizumi et al., 2008). Estos resultados indican una ruta alternativa en la promoción del crecimiento y desarrollo dirigido por GAs sin la necesidad de la degradación de las proteínas DELLA por SLY1/GID2, seguramente mediante el secuestro de las proteínas DELLA a través de su interacción con el receptor GID1.

Las proteínas DELLA son pues componentes principales de la vía de señalización de GAs (Silverstone et al., 1998; Richards et al., 2001). Mientras que en arroz solo se ha encontrado una proteína DELLA, Slender Rice 1 (SLR1) (Ikeda et al., 2001), en Arabidopsis thaliana, las proteínas DELLA estan formadas por cinco miembros, todos pertenecientes a la familia de 
proteínas GRAS (Peng et al., 1997; Silverstone et al., 1998; Lee et al., 2002). Son GAI (del inglés, GA-insensitive), RGA (del inglés, repressor of gal-3), RGL1, RGL2 y RGL3 (del inglés, RGALike 1, 2, 3), que realizan la misma función en diferentes procesos del crecimiento y desarrollo debido a la modulación de su perfil de expresión gobernado por sus promotores más que por su función molecular (Gallego-Bartolomé et al., 2010). Estas proteínas son unos fuertes represores del crecimiento y desarrollo (Harberd, 2003) que pueden ser utilizadas por las plantas para sobrevivir a factores de estrés de tipo biótico y abiótico (Achard et al., 2006; Achard et al., 2008a; Achard et al., 2008b; Navarro et al., 2008). Dentro de la familia GRAS, estas proteínas se diferencian del resto por que poseen, en su extremo N-terminal, un dominio DELLA, acrónimo de los primeros 5 aminoácidos que forman parte de este domino, que les permite interaccionar con el receptor GID1 (Ueguchi-Tanaka et al., 2007; Willige et al., 2007; Murase et al., 2008). Las versiones de estas proteínas donde el domino DELLA es eliminado, son incapaces de interaccionar con el receptor GID1 y no son degradadas por la ruta ubiquitina-proteasoma (Willige et al., 2007). Se ha descrito recientemente que un dominio próximo, VHYNP, parece tener también un papel importante en este proceso (Liu et al., 2010).

En los últimos años, se ha descrito el papel central que ejercen las proteínas DELLA en la señalización de la regulación del desarrollo por luz, clarificando la función de las GAs en la represión de la fotomorfogénesis. La modulación de los niveles de GAs, y como consecuencia, de la acumulación de las proteínas DELLA, puede alterar la respuesta fotomorfogénica tanto a nivel fenotípico como a nivel molecular (Alabadí et al., 2004; Achard et al., 2007). Al minimizar la síntesis de GAs mediante diferentes estrategias, como la aplicación de un inhibidor de la síntesis de GAs como el Paclobutrazol (PAC), o el uso de mutantes en su biosíntesis como gal-3, se produce una acumulación de proteínas DELLA que provoca una respuesta fotomorfogénica en oscuridad (Alabadí et al., 2004; Achard et al., 2007). Además, eliminando las proteínas DELLA en un fondo donde no se sintetizan GAs (gal-3 cuádruple DELLA) este efecto se revierte totalmente (Achard et al., 2007). Este modelo, se ha completado recientemente, con el descubrimiento de la interacción física entre algunas proteínas DELLA y algunos miembros de la familia de las proteínas PIF (de Lucas et al., 2008; Feng et al., 2008) u otros factores de transcripción de la familia bHLH (Gallego-Bartolomé et al., 2010), demostrando que las GAs actúan de una forma coordinada con la luz. Bajo condiciones de iluminación, la síntesis de GAs es baja, lo que conlleva altos niveles de proteínas DELLA que interaccionan con PIF3 y PIF4 impidiendo su unión a los promotores de sus genes diana, y, por tanto, reprimiendo la escotomorfogénesis y promoviendo la fotomorfogénesis (de Lucas et al., 2008; Feng et al., 2008). Al contrario, la síntesis de GAs aumenta en condiciones de oscuridad, lo que conlleva la degradación por el proteasoma de las proteínas DELLA, el consiguiente aumento de PIF3 y PIF4 libres y su unión a los promotores de sus genes diana activando el crecimiento típico de la escotomorfogénesis (de Lucas et al., 2008; Feng et al., 2008). 


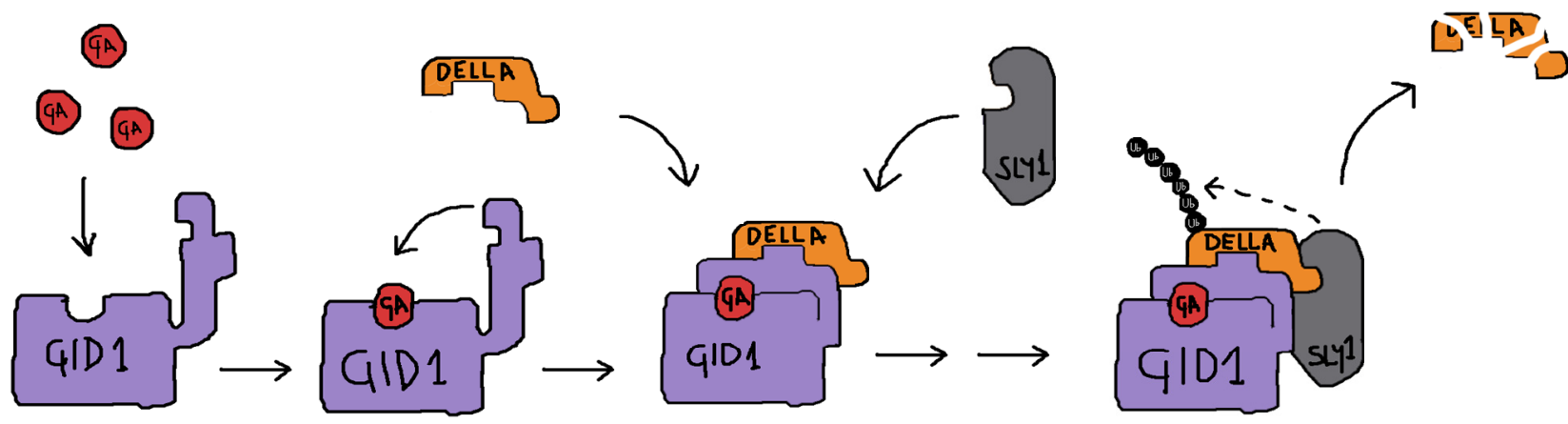

B

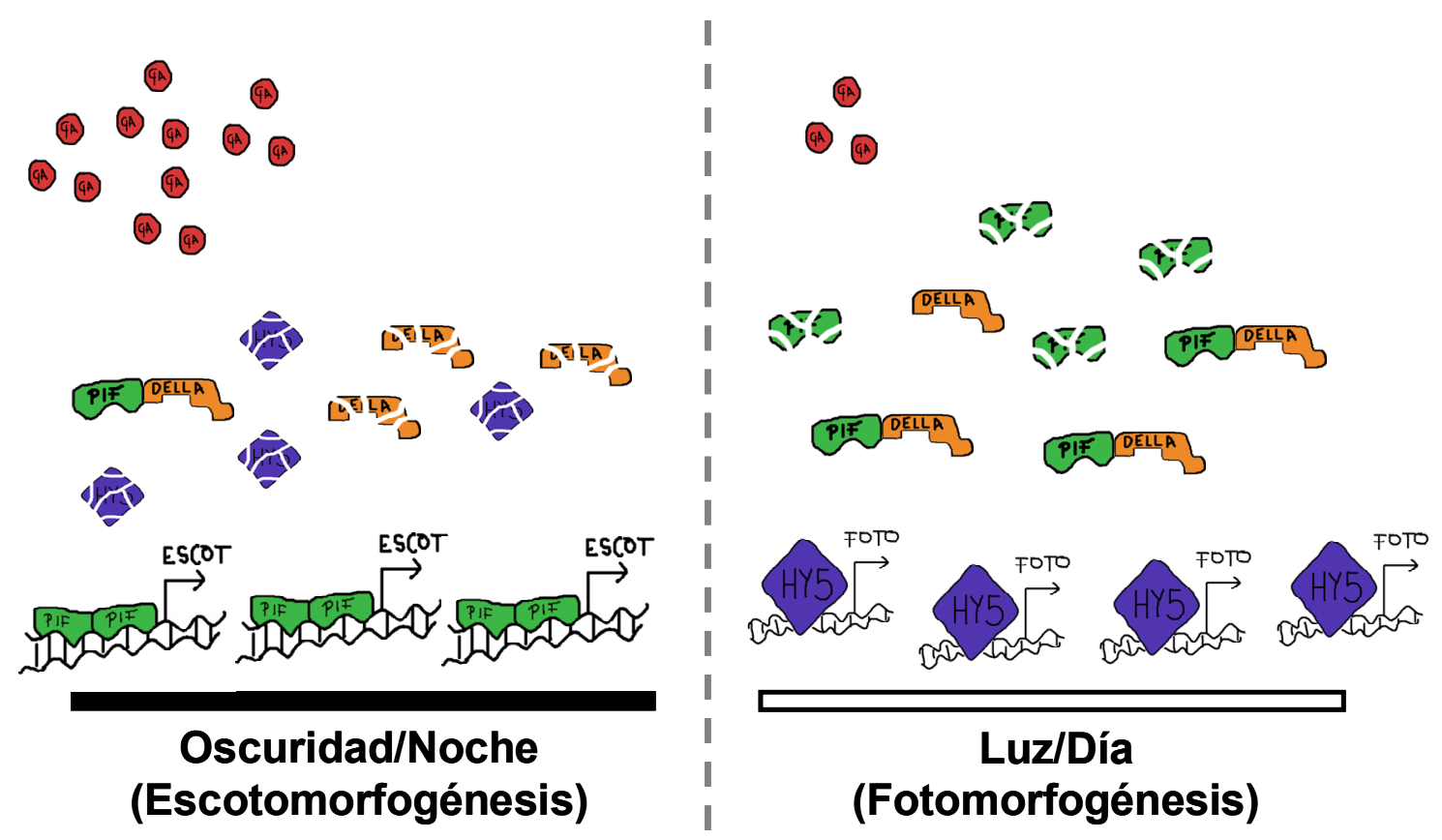

Figura 20. Esquema representando la percepción de las giberelinas por su receptor y su interacción con otros componentes en la regulación del proceso de des-etiolación.

A. Las giberelinas (GA) se unen a su receptor GID1 provocando un cambio conformacional de la proteína que, por un lado atrapa a la molécula de GA dentro del receptor, y por otro, forma una nueva superficie de contacto para la interacción con los represores de la señalización de GAs, las proteínas DELLA. Una vez formado este complejo GAGID1-DELLA, la conformación de la proteína facilita la interacción con la E3 ubiquitin ligasa SLY1. SLY1, que forma parte de un complejo $\mathrm{SCF}^{\mathrm{SLY} 1}$, ubiquitina (Ub) a la proteína DELLA, lo que provoca su posterior degradación por el proteasoma, liberando su efecto negativo sobre la señalización de GAs y permitiendo una correcta transducción de la señal. B. En situaciones de oscuridad existe una elevada cantidad de GAs que promueven la degradación de las DELLA. Los PIF, estables en oscuridad, se encontrarán en forma libre y serán capaces de dimerizar y activar la escotomorfogénesis (ESCOT). El factor de transcripción HY5 se degrada en oscuridad a través de COP1 (no representado). Cuando las plantas pasan a condiciones de iluminación, los niveles de GAs caen drásticamente, se acumulan las DELLA y secuestran a los PIF que hayan evitado su degradación por luz. Así mismo, puesto que COP1 se degrada en luz, existirá un conjunto de proteínas HY5 que activaran sus genes diana promoviendo así la fotomorfogénesis (FOTO). 
Además, los factores de transcripción PIFs no son los únicos que regulan este proceso, ni las únicas dianas de la señalización por GAs. Se ha descrito que las GAs modulan negativamente la acumulación de la proteína HY5, un factor de transcripción clave para la promoción de la fotomorfogénesis. Aunque este fenómeno no esta todavía definido por completo a nivel molecular, COP1, la proteína encargada de degradar HY5, podría ser el punto de regulación modulado por las GAs (Alabadí et al., 2008), si bien, no se tiene todavía una evidencia clara de la acumulación de esta proteína en un fondo deficiente en la síntesis de GAs o en mutantes de su señalización.

Además de las hormonas, existen otras moléculas como el NO que parecen cumplir una función señalizadora en la regulación del desarrollo por luz. En trabajos iniciales, se describió que la aplicación del donador de NO, nitroprusiato sódico (SNP), promueve la activación de genes de respuesta a luz (Bowler et al., 1994b; Bowler et al., 1994a) a través de la producción de cGMP, un segundo mensajero del NO, que junto al calcio/calmodulina, es indispensable para la señalización por luz dependiente de fitocromos (Bowler et al., 1994a; Bowler et al., 1994b; Neuhaus et al., 1997). El NO podría ser, por tanto, una de las moléculas que descifre la información de la luz después de ser percibida por los fitocromos. De acuerdo con esto, se describió que el NO inhibe la elongación de los hipocotilos crecidos en oscuridad y promueve la fotomorfogénesis en plántulas de girasol y de Arabidopsis thaliana (Beligni y Lamattina 2000). El NO es capaz también de activar genes regulados por luz y de incrementar el contenido en clorofilas (Beligni y Lamattina, 2000).

De acuerdo con estos datos, el NO tendría un papel opuesto al de las GAs en la regulación del desarrollo por luz. Esta interacción antagonista entre las GAs y el NO ha sido descrita en otros procesos como la muerte celular programada de la capa de aleurona de semillas de cereales o la transición a la floración (Beligni et al., 2002; He et al., 2004). Sin embargo, también han sido descritas sinergias GAs-NO en otros procesos como la germinación (Bethke et al., 2007; FinchSavage et al., 2007). El papel del NO en la respuesta a luz, al igual que las GAs, puede estar relacionado con la elongación celular. Las GAs promueven el crecimiento regulando la elongación celular (Nitsan y Lang 1966; Loy y Liu 1974; Cowling et al., 1998) a través de la degradación de las proteínas DELLA. Además, la endodermis parece ser el tejido responsable de la regulación del crecimiento de la raíz por GAs (Ubeda-Tomas et al., 2008), si bien se ha descrito también el control de la división celular regulado por GAs en el meristemo de la raíz (Achard et al., 2009; Ubeda-Tomas et al., 2009). En este tejido, las DELLA promueven una expresión elevada de proteínas que bloquean el ciclo celular reprimiendo la división, que se restaura en presencia de GAs (Achard et al., 2009; Úbeda-Tomas et al., 2009). En la parte aérea, las GAs también regulan la elongación celular a través de los PIFs aunque se desconoce el tipo celular implicado y las dianas de su acción (de Lucas et al., 2008). Entre las posibles dianas, los genes que codifican proteínas para la maquinaria de reciclaje de la pared celular así como proteínas de transferencia de lípidos que ayudan con la remodelación de la membrana plasmática, parecen ser necesarios para la 
elongación celular (de Lucas et al., 2008). En cuanto al NO, también parece tener un papel en la elongación celular, actuando de manera negativa en la elongación del tubo polínico y las células del mesocotilo en monocotiledóneas (Zhang et al., 2003; Prado et al., 2004; Reichler et al., 2009). De todas formas, el papel del NO en la elongación parece ser algo más complejo ya que también se ha descrito un papel positivo sobre la elongación/crecimiento de los pelos radiculares (Lombardo et al., 2006). En modelos animales, se cree que el NO afecta negativamente a la elongación celular (Trimm y Rehder 2004; Yamada et al., 2006; Tornieri y Rehder 2007). Por otro lado, también se tienen evidencias de la participación del $\mathrm{NO}$ en procesos de división celular, controlando el ciclo celular (Otvos et al., 2005; Correa-Aragunde et al., 2006), lo que podría eventualmente afectar a procesos de elongación/crecimiento celular mediante mecanismos de compensación (Horiguchi et al., 2006; Shin et al., 2007).

En este trabajo tratamos de averiguar el papel del NO en la regulación del desarrollo por luz así como su interacción con la señalización de GAs. También estamos interesados en saber si PIFs y DELLAs son elementos comunes en la señalización de estas dos moléculas regulando la fotomorfogénesis y la elongación celular reprimida por la luz. 


\section{RESULTADOS}

\section{El mutante deficiente en NO, nia1,2noa1-2, presenta hipocotilos largos en luz}

A pesar del retraso general en el crecimiento detectado en el triple mutante nial,2noal-2 (ver capítulos anteriores), observamos que sus hipocotilos crecen más alargados que los de plántulas silvestres en luz blanca bajo condiciones fotoperiódicas de días largos. Así, cinco días después de la germinación, los hipocotilos del triple mutante midieron el doble que los de las plántulas silvestres (Fig. 21A). Este mayor crecimiento, no fue el resultado de un efecto general de la deficiencia en NO sobre el crecimiento del hipocotilo ya que los hipocotilos de las plántulas del triple mutante y de individuos silvestres presentaron la misma elongación en condiciones de oscuridad (Fig. 21A). Además, este efecto sobre el crecimiento parecía específico del hipocotilo ya que las raíces del mutante presentaron un comportamiento opuesto. El triple mutante presentó una raíz mucho menor que la de plantas silvestres en condiciones de iluminación pero no en condiciones de oscuridad (Fig. 21B). El fenotipo diferencial, tanto en hipocotilos como en raíces, en condiciones de luz pero no en oscuridad sugería que el NO podría regular procesos de desarrollo en conexión con la luz. Además, el mutante nial,2noal-2 es totalmente capaz de reprimir la fotomorfogénesis en condiciones de oscuridad, indicando que el NO no es esencial para la regulación del desarrollo escotomorfogénico. Sin embargo, el triple mutante presenta alteraciones tanto en la elongación del hipocotilo como en la de la raíz en presencia de luz, apuntando a un requerimiento del $\mathrm{NO}$ en la activación del programa de fotomorfogénesis. Centrándonos en el fenotipo de elongación del hipocotilo, comprobamos primero si la deficiencia en la respuesta fotomorfogénica del mutante afectado en la síntesis de NO era general en todas las calidades de luz, o específica de alguna de ellas. Para ello, medimos el crecimiento del hipocotilo, en todos los mutantes deficientes en la biosíntesis de NO en condiciones de luz azul, roja lejana y roja cinco días tras la germinación. Las luces azul y roja lejana reducen la elongación del hipocotilo de la misma forma en mutantes NO-deficientes que en plántulas silvestres (Fig. 21C). Sin embargo, bajo condiciones de luz roja, los mutantes deficientes en NO presentaron hipocotilos más alargados que los de las plántulas silvestres, siendo el efecto ligero en el mutante nial,2, más acentuado en noal-2 y aditivo en el caso de nial,2noal-2 (Fig. 21C). Además, el efecto fue dependiente del tiempo y también de la intensidad de la luz aplicada (Fig. 22). 
A $\bar{E}$

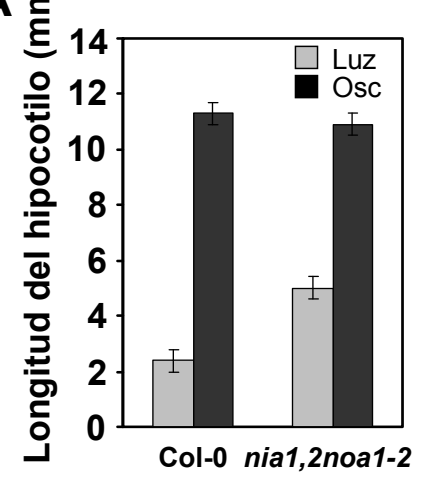

C

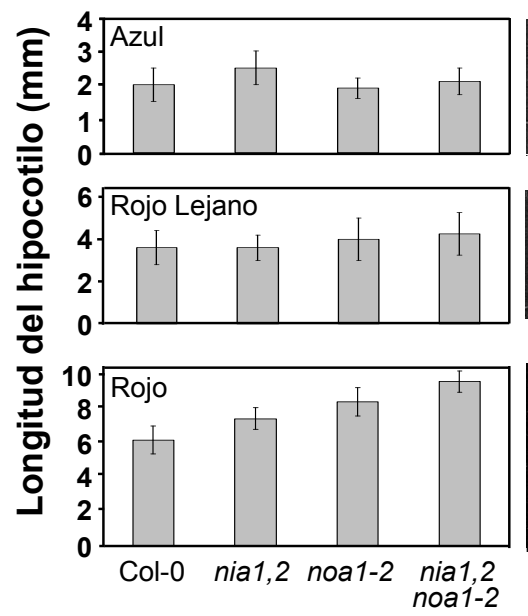

B

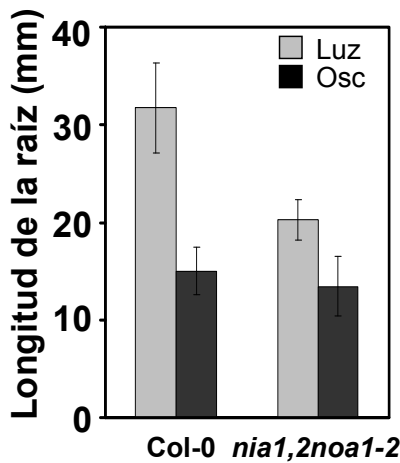

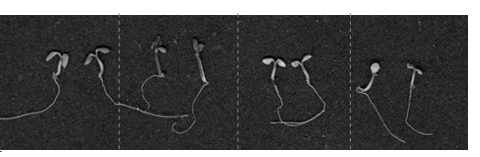
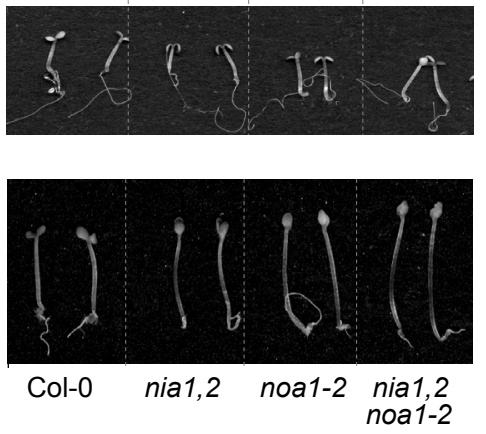

D $\widehat{\varepsilon}$

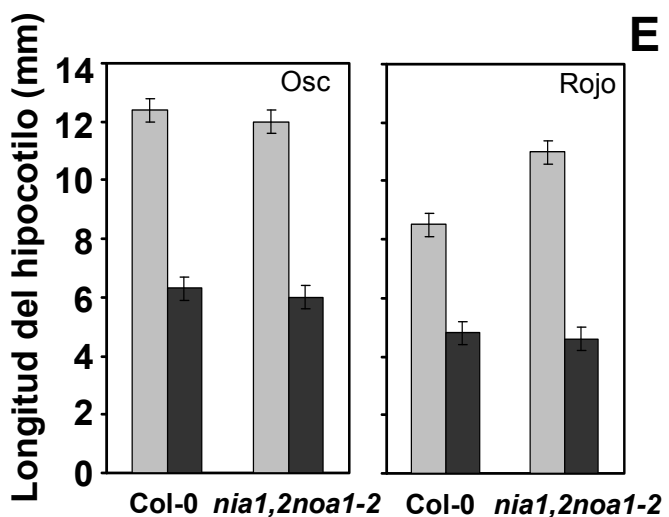

E

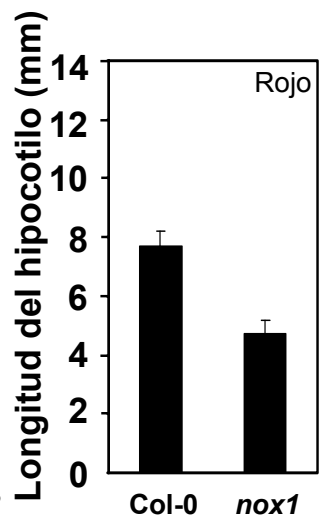

Figura 21. Longitud del hipocotilo y la raíz en plantas deficientes en NO bajo diferentes condiciones.

A. Longitud del hipocotilo (A) y la raíz (B) de plantas silvestres y deficientes en NO bajo luz blanca (gris claro) o en oscuridad (gris oscuro). Las longitudes del hipocotilo y de la raíz se midieron 5 y 10 días tras la germinación, respectivamente. C. Longitud del hipocotilo de plántulas de 5 días crecidas en luz azul $\left(16,5 \mu \mathrm{mol} \mathrm{m}^{-2} \mathrm{~s}^{-1}\right)$, rojo lejano (5 $\left.\mu \mathrm{mol} \mathrm{m} \mathrm{m}^{-1}\right)$ o rojo $\left(20 \mu \mathrm{mol} \mathrm{m} \mathrm{m}^{-2} \mathrm{~s}^{-1}\right)$. A la derecha se muestran individuos representativos de las plántulas que se utilizaron para hacer las medidas. D. Longitud del hipocotilo en plantas tratadas ( $250 \mu \mathrm{M} \mathrm{SNP}$, gris oscuro) o no tratadas (gris claro) con el donador de NO SNP, en condiciones de oscuridad o luz roja. E. Tamaño del hipocotilo de plántulas Col-0 y noxl crecidas en luz roja durante 5 días. Los valores representan las medias \pm error estándar de tres experimentos independientes, midiendo al menos 20 plántulas en cada experimento.

Mientras que las plántulas silvestres empezaron a detener su crecimiento tras cinco días en luz roja, el triple mutante continuó creciendo a su tasa máxima (Fig. 22). De la misma forma, bajo una intensidad de $10 \mu \mathrm{mol} \mathrm{m} \mathrm{m}^{-2} \mathrm{~s}^{-1}$, las plántulas silvestres inhibieron su crecimiento un $40 \%$, 
mientras que esta inhibición fue de un $25 \%$ a un $5 \%$ en plántulas de nia1,2, noal-2 o nial,2noal2, respectivamente (Fig. 22). De acuerdo con estos datos y tal y como ha sido descrito previamente, el tratamiento con el donador de NO resultó en la inhibición de le elongación del hipocotilo, complementando totalmente el fenotipo de hipocotilos elongados del triple mutante (Fig. 21D; Beligni y Lamattina, 2000). Además, el mutante noxl que acumula un mayor contenido endógeno de NO (He et al., 2004), presentó una reducción del tamaño del hipocotilo en condiciones de luz roja (Fig. 21E). Estos datos indican inequívocamente que el NO regula el tamaño del hipocotilo (Fig. 21) y además, validan la utilización de SNP como donador de NO en este proceso, ya que tiene un efecto muy similar al de la producción endógena de NO (Fig. 21).

A



B

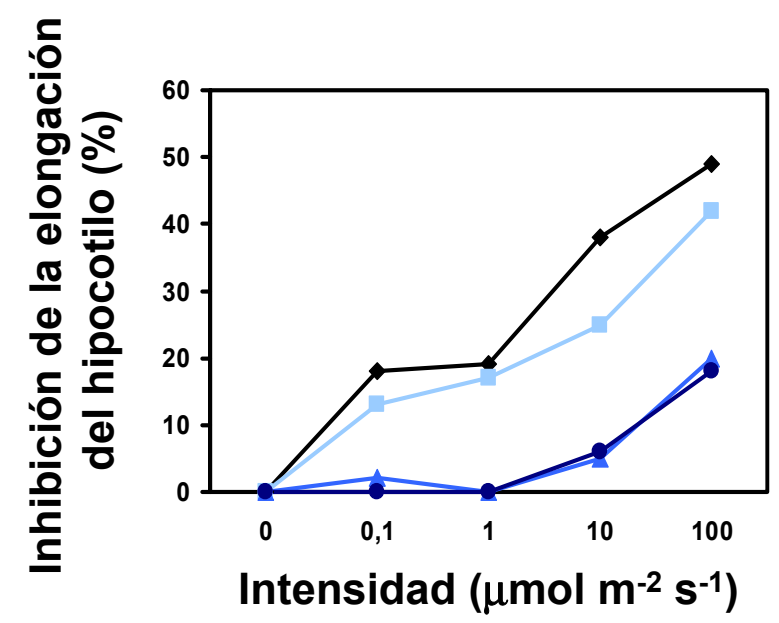

Figura 22. Longitud del hipocotilo en función del tiempo y de la intensidad de luz en los diferentes mutantes deficientes en NO.

A. El tamaño del hipocotilo fue medido a los tiempos indicados de crecimiento en luz roja. B. Inhibición de la elongación de los hipocotilos a las diferentes intensidades de iluminación indicadas y a los cinco días después de la germinación Los valores representan media \pm error estándar. 
EI NO reduce la expresión de los genes PIFs y provoca la acumulación de las proteínas DELLA para regular el tamaño del hipocotilo

La reducida inhibición de la elongación del hipocotilo que encontramos en los mutantes deficientes en NO únicamente bajo condiciones de iluminación con luz roja sugiere que la percepción o la señalización de la luz roja están afectadas en dichos mutantes. Ya que la luz roja se percibe, principalmente, mediante el Fitocromo B (PHYB) (Bae y Choi, 2008), estudiamos si la deficiencia en NO impide la correcta acumulación de esta proteína. Mediante anticuerpos específicos contra PHYB, comprobamos que el mutante nia 1,2noal-2 acumula niveles normales de PHYB bajo condiciones de oscuridad, condiciones donde los niveles de acumulación de dicha proteína son máximos (Fig. 23;(Leivar et al., 2008a). Sin embargo, bajo condiciones de iluminación con luz roja, el triple mutante presentó niveles reducidos de PHYB (Fig. 23). Además, los hipocotilos del mutante $p h y B$ respondieron igual que los hipocotilos silvestres, al tratamiento con SNP, tanto en condiciones de oscuridad como de luz roja (Fig. 23C). Parece entonces que es la señalización dependiente de PHYB la que está alterada en el triple mutante, ya que de no ser así cabría esperar un defecto en todas las respuestas dependientes de PHYB en el mutante nial,2noal2. Ambos mutantes, nial,2noal-2 y phyB, comparten algunos fenotipos como hipocotilos alargados bajo luz roja, hojas con un menor contenido en clorofilas, bajas tasas de transpiración, mayor acumulación de antocianinas y una ramificación reducida (Tabla 3 y sus referencias). Sin embargo, la mayor elongación de los peciolos, de los pelos radiculares y del tallo así como el fenotipo de floración temprana en condiciones fotoperiódicas de días cortos, características del mutante $p h y B$, no se observaron en el mutante nial,2noal-2 (Tabla 3). El hecho de que no se observen todos los fenotipos del mutante $p h y B$ en el mutante nial,2noal-2 y que el mutante phyB responda a la inhibición de la elongación del hipocotilo por NO, sugiere que los mutantes deficientes en NO están afectados en la señalización por debajo de PHYB más que en la función de PHYB en la percepción de la luz roja.

Ya que las plántulas nia1,2noal-2 acumularon tres veces más antocianinas que las plántulas silvestres en luz (Fig. 24C) y dado que muchos de los genes que codifican los enzimas de la síntesis de antocianinas y flavonoides son dianas de PIF3 (Shin et al., 2007), el NO podría interferir con la señalización dependiente de PHYB a través de PIF3. Además, se ha descrito que PIF3 y PIF4, regulan negativamente la acumulación de PHYB en condiciones de luz roja (AlSady et al., 2008; Leivar et al., 2008a), lo que esta de acuerdo con los niveles reducidos de PHYB que encontramos en el triple mutante en luz roja. (Fig. 23). 
Tabla III. Análisis comparativo de los fenotipos de los mutantes phyB y nia1,2noal-2.

Los fenotipos analizados en las referencias citadas fueron comparados con los encontrados en el mutante nial,2noal-2 (ver capítulos anteriores).

\begin{tabular}{lccl} 
Caracter & phyB & nial,2noal-2 & Referencia \\
\hline Hipocotilos elongados & $\mathrm{Si}$ & $\mathrm{Si}$ & Reed et al., 1993 \\
Peciolos largos & $\mathrm{Si}$ & $\mathrm{Si}$ & Reed et al., 1993 \\
Menos clorofilas & $\mathrm{Si}$ & $\mathrm{Si}$ & Reed et al., 1993 \\
Tallos alargados & $\mathrm{Si}$ & $\mathrm{No}$ & Reed et al., 1993 \\
Rá́z reducida & $\mathrm{Si}$ & $\mathrm{Si}$ & Correll and Kiss, 2005 \\
Pelos radiculares alargados & $\mathrm{Si}$ & $\mathrm{No}$ & Reed et al., 1993 \\
Floración temprana & $\mathrm{Si}$ & $\mathrm{No}$ & Reed et al., 1993; Guo et al., 1998 \\
Transpiración reducida & $\mathrm{Si}$ & $\mathrm{Si}$ & Boccalandro et al., 2009 \\
Ramificación reducida & $\mathrm{Si}$ & $\mathrm{Si}$ & Reed et al., 1993 \\
Germinación reducida & $\mathrm{Si}$ & $\mathrm{Si}$ & Shinomura et al., 1994
\end{tabular}

A

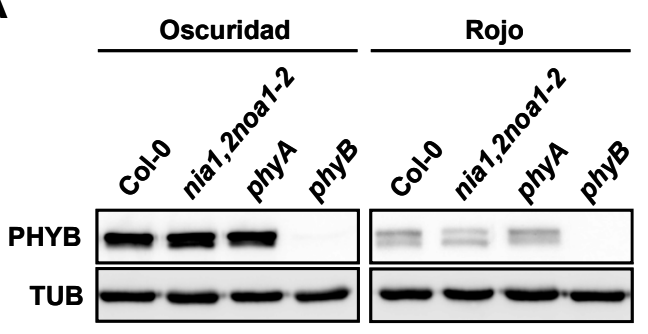

B

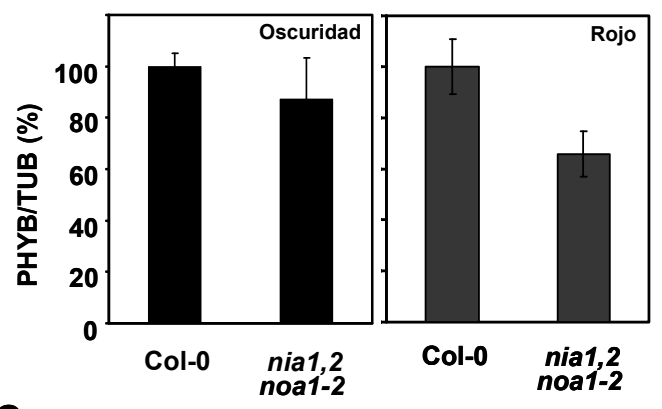

C

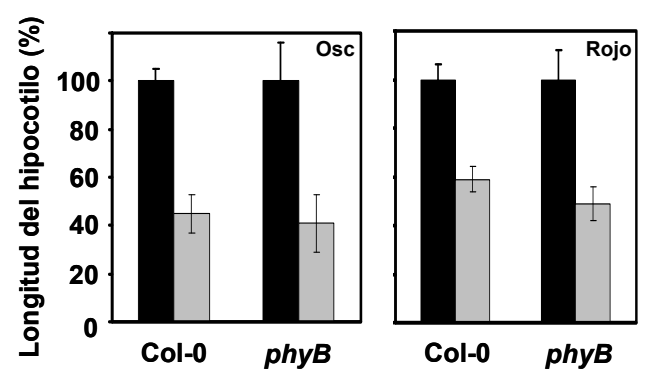

Figura 23. Niveles de la proteína PHYB en diferentes mutantes y comportamiento del mutante phyB en respuesta al NO.

A. Western-blot con anticuerpos anti-PHYB de muestras de los distintos genotipos mantenidos durante 3 días en oscuridad o en luz roja $\left(7 \mu \mathrm{mol} \mathrm{m}^{-}\right.$ $\left.{ }^{2} \mathrm{~s}^{-1}\right)$. Se muestra la hibridación con el anticuerpo anti-Tubulina como control de carga. B. Cuantificación de la acumulación de PHYB normalizada a la cantidad de Tubulina y expresada como los niveles relativos a los de Col-0. Los valores son la media de tres experimentos independientes \pm desviación estándar. C. Tamaño relativo del hipocotilo de plántulas Col-0 y phyB tratadas (gris) o no (negro) con $250 \mu \mathrm{M}$ SNP bajo condiciones de oscuridad o luz roja. Los valores representan las medias \pm error estándar de tres experimentos independientes, midiendo al menos 20 plántulas en cada experimento. Los asteriscos representan una diferencia significativa ( $\mathrm{p}$-valor $<0,05$ por test- $\mathrm{t}$ ). 
Apoyando esta hipótesis, hemos encontrado que el triple mutante presenta niveles de transcrito PIF3 más elevados que los detectados en plántulas silvestres, y esta mayor expresión se detectó también para otros bHLH del grupo de los PIFs como PIF1 y PIF4 (Fig. 24A). Consecuentemente, los niveles de expresión de estos genes $P I F \mathrm{~s}$ se vieron significativamente reducidos tras la aplicación de SNP (Fig. 24A). Además, como se podría esperar de plántulas con una función incrementada de estos PIFs (de Lucas et al., 2008; Feng et al., 2008), las plántulas nial,2noal-2 tienen una respuesta alterada tanto a $\mathrm{GA}_{3}$ como al inhibidor de la biosíntesis de GAs, Paclobutrazol (PAC) (Fig. 24B,D). Tanto plántulas silvestres como nial,2noal-2 reducen el tamaño de sus hipocotilos tras la aplicación de PAC, pero el triple mutante presentó una clara hiposensibilidad a PAC en todas las concentraciones estudiadas (Fig. 24B). También se observó una alteración en la sensibilidad a GAs en el triple mutante. Mientras que los hipocotilos de plántulas nial,2noal-2 alcanzaron su tamaño máximo con una aplicación de $1 \mu \mathrm{M} \mathrm{GA}_{3}$, las plántulas silvestres necesitaron de una aplicación de $5 \mu \mathrm{M} \mathrm{GA}_{3}$ para alcanzar el mismo tamaño (Fig. 24D). Por otro lado, los hipocotilos de plántulas que sobreexpresan PIF3 (PIF3OX) son ligeramente más sensibles a la inhibición del tamaño del hipocotilo por NO (Fig. 24E,F). En contraposición, un cuádruple mutante piflpif3pif4pif5 (pifQ) fue casi totalmente insensible a la inhibición de la elongación del hipocotilo provocada por el NO (Fig. 24E,F). Todos estos datos sugieren que existe una función incrementada de las proteínas PIF en el mutante deficiente en NO y además, que los PIF son dianas del NO en la regulación del tamaño del hipocotilo. 
A

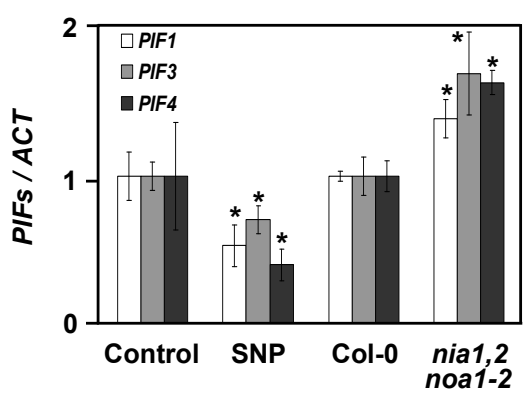

C

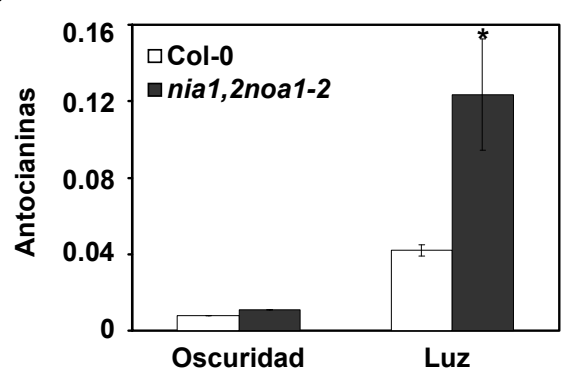

E

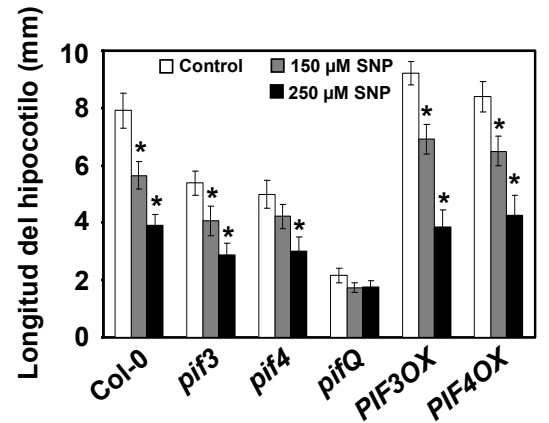

B
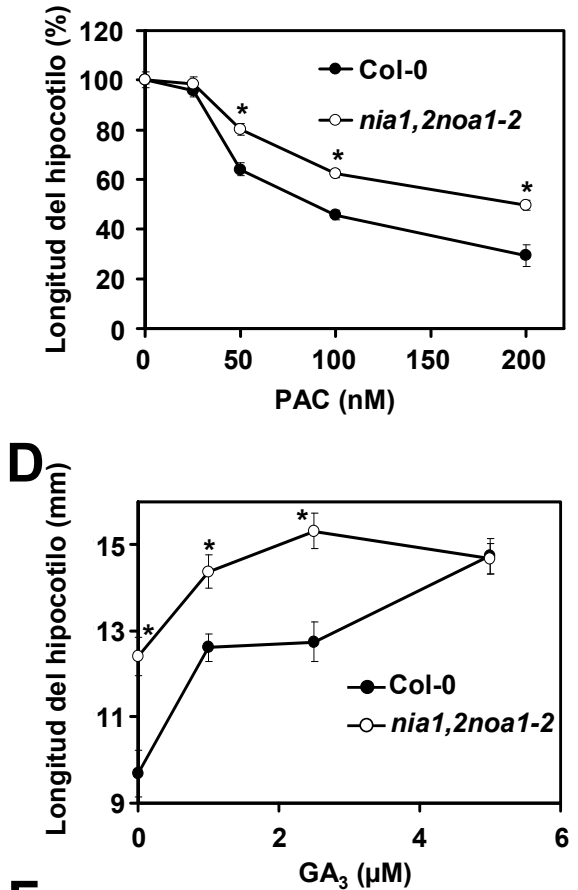

$F$

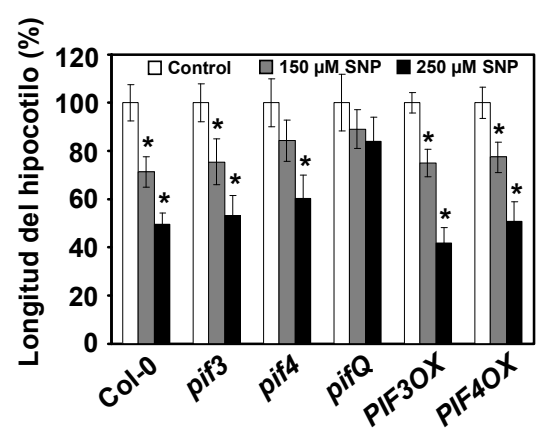

Figura 24. Conexión funcional entre el NO, las giberelinas y los PIF.

A. Niveles de expresión de PIF1, PIF3 y PIF4 en hipocotilos de plántulas no tratadas (Control) o tratadas (SNP) con $1 \mathrm{mM}$ SNP durante 2 horas, así como en plántulas Col-0 o nial,2noal-2 no tratadas. B. Longitud del hipocotilo de los genotipos indicados (media \pm error estándar) en plántulas cultivadas bajo las concentraciones indicadas de PAC. C. Niveles de antocianinas en Col-0 y nial,2noal-2 en oscuridad o luz blanca expresados como unidades arbitrarias de absorbancia a $530 \mathrm{~nm}$. D. Tamaño de los hipocotilos de plántulas de Col-0 y nial,2noal-2 (media \pm error estándar) tratadas con las concentraciones de $\mathrm{GA}_{3}$ indicadas. E y F, Tamaño total y relativo, respectivamente, de los hipocotilos de plántulas de los diferentes genotipos tratadas o no con SNP. Todos los experimentos se realizaron bajo luz roja excepto cuando se indica lo contrario. Los valores son medias de tres experimentos independientes \pm error estándar. Los asteriscos representan diferencias significativas con $\mathrm{p}$-valor $<0,05$ cuando se comparan con el control o con el genotipo silvestre.

La actividad de las proteínas PIF en la regulación del tamaño del hipocotilo es controlada por su asociación con las proteínas DELLA (de Lucas et al., 2008; Feng et al., 2008), cuyos niveles son regulados a través de su degradación proteolítica mediada por las GAs (Dill et al., 2004; Achard et al., 2007; (Harberd et al., 2009). La sensibilidad alterada a GAs y PAC del triple mutante así como la función incrementada de los PIF que encontramos en el mutante, pueden ser 
explicadas también por niveles reducidos de las proteínas DELLA en los mutantes deficientes en NO. Para comprobar el posible papel regulador del NO en la acumulación de las DELLA, plantas transgénicas que expresan una versión de la proteína DELLA, RGA, fusionada traduccionalmente a GFP, bajo el control de su propio promotor ( $p R G A:: G F P-R G A)$ fueron tratadas con SNP. De acuerdo con la degradación de las DELLA mediada por GAs (Dill et al., 2004; Achard y Genschik 2009), la fluorescencia asociada a GFP-RGA desapareció tanto en raíces como en hipocotilos de plántulas tratadas con $\mathrm{GA}_{3}$ (Fig. 25A,B). Al contrario, plántulas tratadas con SNP exhibieron un incremento significativo en los niveles de fluorescencia asociada a GFP-RGA en los núcleos (Fig. 25A). El incremento en GFP-RGA tras el tratamiento con SNP, se comprobó también por Western-blot de plántulas enteras mediante anticuerpos contra GFP (Fig. 25A). Además, para comprobar si los niveles endógenos de NO pueden controlar la acumulación de la proteína RGA, se introgresó la línea $p R G A:: G F P-R G A$ en el fondo nial,2noal-2. En la figura 25B se muestra la dinámica de la acumulación de la proteína GFP-RGA en diferentes fondos genéticos, tras pasar plántulas de oscuridad a luz. La fluorescencia GFP-RGA se detectó dos horas después de pasar las plántulas $p R G A:: G F P-R G A$ en el fondo silvestre a luz (Fig 25B). Sin embargo, no se detecto dicha acumulación en las plántulas en fondo deficiente en NO (Fig. 25B). Cuatro horas tras pasar las plántulas a luz, la proteína GFP-RGA empezó a acumularse en el fondo nia1,2noal-2, siendo sus niveles significativamente menores que los que se acumularon en plántulas transgénicas del fondo silvestre (Fig. 25B). Estos datos sugieren que el NO es necesario para la correcta acumulación de la proteína RGA en respuesta al estímulo lumínico, y que las plantas deficientes en NO contienen niveles reducidos de RGA en determinadas situaciones, como son las transiciones diarias oscuridad-luz. En contraposición, las plántulas $p R G A:: G F P-R G A$ en el fondo gal-3 (Stavang et al., 2009), acumularon niveles máximos de GFP-RGA incluso en oscuridad (Fig. 25B) debido a la ausencia de giberelinas de este mutante (Achard et al., 2007).

Por otra parte, hemos comprobado que este efecto no es específico de RGA sino que es similar en el resto de DELLAs. Haciendo uso de líneas transgénicas 35S::TAP-DELLA (Feng et al., 2008), hemos analizado los niveles de las cinco proteínas DELLA tras el tratamiento con NO y/o GA 3 . Como se muestra en la Figura 25C, existe una mayor acumulación de todas las proteínas DELLA en respuesta a NO. Al contrario, comprobamos que la aplicación de $\mathrm{GA}_{3}$ provocaba la degradación de las mismas (Fig. 25C), tal y como está descrito en la literatura. 
A

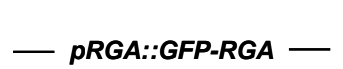
B Raíz Hipocotilo

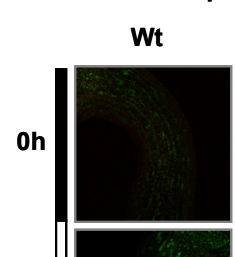
PRGA::GFP-RGA
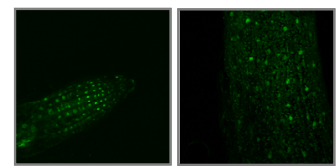

$\mathbf{G A}_{3}$
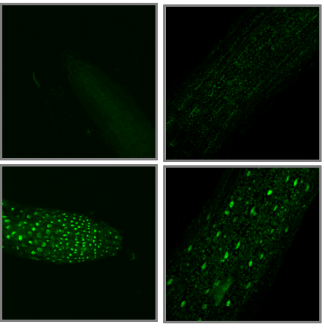

Cont NO

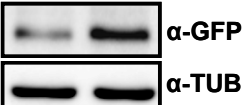

C

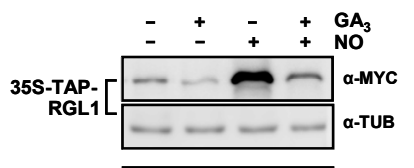

$2 \mathrm{~h}$

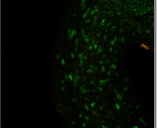

nia1,2noa1-2

ga1-3
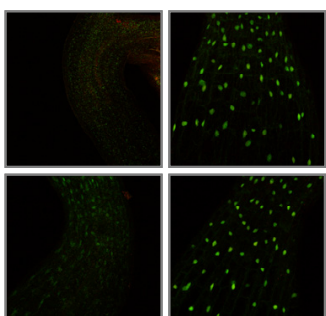

NO
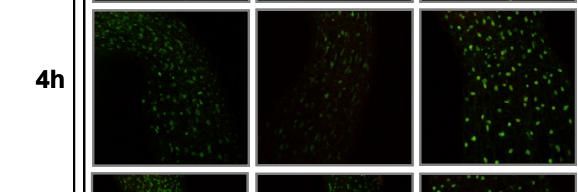

$8 h$
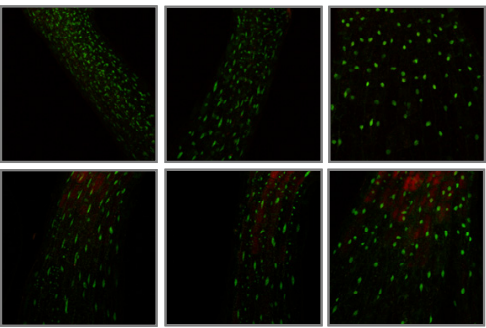

\section{E}
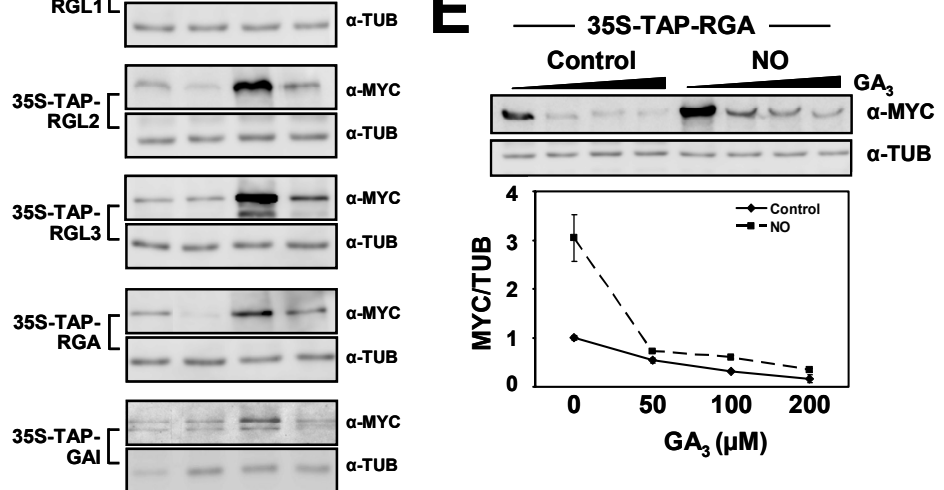

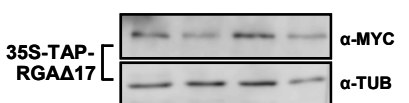

35S-TAP- $\ldots \ldots$ a-MYC

GAID17

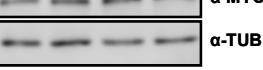

F
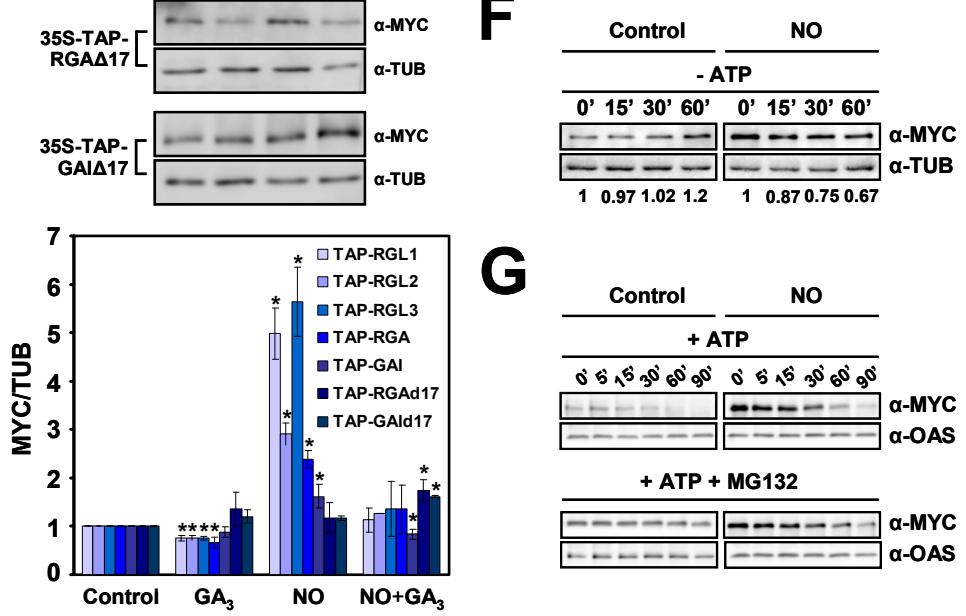

G

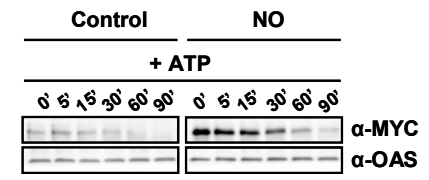

+ ATP + MG132 a-MYC
a-OAS

D
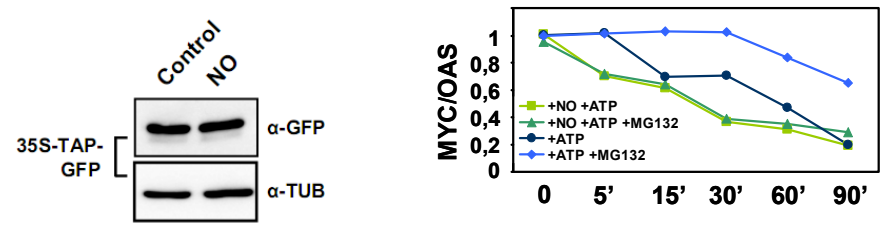
Figura 25. Efecto del NO en la acumulación de las proteínas DELLA.

A. Los niveles de GFP-RGA fueron visualizados en las raíces y los hipocotilos de plántulas $p R G A: \because G F P-R G A$ tanto sin tratar $(\mathrm{C}$, Control) como tras un tratamiento de $2 \mathrm{~h}$ con $50 \mu \mathrm{M} \mathrm{GA} 3$ y/o $250 \mu \mathrm{M}$ SNP, como fuente de NO (NO) mediante microscopia confocal. Los niveles de GFP-RGA y el control de carga, Tubulina (TUB) fueron analizados mediante Western-blot. B. Acumulación de la proteína GFP-RGA en la línea $p R G A: \because G F P-R G A$ en los fondos genéticos, silvestre (Wt), nia1,2noal-2 y gal-3 a diferentes tiempos tras pasar las plántulas de oscuridad (barra negra vertical) a luz (barra blanca vertical). C. Análisis de los niveles de TAP-DELLAs tras el tratamiento con SNP (NO) y/o GA 3 durante 2,5 h detectados mediante anticuerpos anti-MYC. Se presenta la hibridación con TUB como control de carga. Los valores normalizados con los de TUB y referidos a los valores del control no tratado fueron cuantificados y se presentan como valores medios \pm desviación estandar de tres experimentos independientes. Los asteriscos indican valores significativos tras un test-t, p-valor $<0,05$. D. Efecto del tratamiento con SNP (NO) en la acumulación de la proteína TAP-GFP. E. Degradación de TAP-RGA inducida por GAs en plantas no tratadas (Control) y tratadas con NO (NO, como se indica en el panel C). Las concentraciones de $\mathrm{GA}_{3}$ utilizadas durante 2,5 h fueron $0,50,100$ y $200 \mu \mathrm{M}$. Los valores normalizados con la TUB fueron cuantificados y se muestran como la media \pm error estandar de tres experimentos independientes. E y F. Ensayos de degradación in vitro en ausencia (E) o presencia (F) de ATP y el inhibidor del proteasoma MG132. Las muestras se incubaron a temperatura ambiente por los tiempos y tratamientos indicados. Se utilizó anti-MYC para detectar TAP-RGA y TUB o anti-OAS-TL A1 (OAS) como control de carga. El ATP y el MG132 fueron utilizados a $10 \mathrm{mM}$ y $100 \mu \mathrm{M}$, respectivamente. Los niveles de proteína detectados en el panel F se cuantificaron y normalizaron con los de OAS y se presentan en la gráfica correspondiente.

Además, el pre-tratamiento con el donador de $\mathrm{NO}$ y la aplicación posterior de $\mathrm{GA}_{3}$ no previno la degradación de las DELLA mediada por GAs (Fig. 25C), sugiriendo que el NO no está modificando las proteínas DELLA haciéndolas resistentes a la degradación por el proteasoma. Hemos confirmado esta idea monitorizando la acumulación de TAP-RGA tras la aplicación de diferentes concentraciones de $\mathrm{GA}_{3}$ en plantas pre-tratadas, o no, con el donador de NO (Fig. 25E). La proteína TAP-RGA fue degradada eficientemente tanto en plantas tratadas con NO como en plantas no tratadas (Fig. 25E). De hecho, la degradación de TAP-RGA por $\mathrm{GA}_{3}$ parece ser más eficiente en plántulas pre-tratadas con NO. Entonces, exploramos si la degradación de las DELLA en plántulas tratadas con NO esta mediada por la actividad dependiente de ATP del proteasoma mediante un sistema in vitro descrito previamente (Wang et al., 2009a). La Figura 25F, G muestra que no existe degradación de TAP-RGA en ausencia de ATP en plántulas no tratadas con NO mientras que la degradación es evidente en las plántulas tratadas con $\mathrm{NO}$, sugiriendo que la proteína TAP-RGA en estos extractos puede ser degradada también por un mecanismo independiente del proteasoma. Sin embargo, tanto TAP-RGAs no tratadas, como tratadas con NO, son progresivamente degradadas en el tiempo en extractos con ATP, siendo las últimas más susceptibles a degradación (Fig. 25F, G). Además, el inhibidor del proteasoma MG132 retardo la degradación de TAP-RGA en controles no tratados pero solo hasta cierto límite en muestras tratadas con NO (Fig. 25G), sugiriendo de nuevo que existe una degradación independiente del proteasoma en las plántulas tratadas con NO. Este mecanismo alternativo de degradación puede también explicar la degradación más eficiente que observamos en plántulas tratadas con NO en respuesta a $\mathrm{GA}_{3}$ (Fig. 25E) o en ausencia de ATP (Fig. 25F). Por otro lado, comprobamos que el tratamiento con el dador de NO, SNP, no provocaba una mayor acumulación de proteína TAPGFP en líneas 35S::TAP-GFP (Fig. 25D). 


\section{EI NO provoca la acumulación de DELLAs mediante la represión de SLY1}

Los hipocotilos de plántulas silvestres cultivadas en luz roja bajo cantidades crecientes de NO se vieron progresivamente acortados (Fig. 26). A concentraciones de $0.5 \mathrm{mM} \mathrm{SNP}$, la elongación del hipocotilo fue de en torno al 10\% de la elongación de plántulas no tratadas (Fig. 26A). El acortamiento del hipocotilo con cantidades crecientes de SNP se correlacionó muy bien con la acumulación de las DELLA, siendo GAI la proteína DELLA menos sensible a NO (Fig. 26B). Además, la inhibición de la elongación del hipocotilo ejercido por el NO bajo condiciones de luz roja es parcialmente dependiente de la función de las DELLA (Fig. 26C). El doble mutante rgagai presenta una ligera reducción de la respuesta a NO que se convierte en una insensibilidad mucho más pronunciada en el cuádruple mutante DELLA, 4della, que tiene mutados todos los genes que codifican proteínas DELLA menos RGL3 (Achard et al., 2006), y también en el mutante en las cinco DELLAs, 5della (Fig. 26C). En el rango de concentraciones de SNP utilizadas, la longitud de los hipocotilos de los mutantes 4della y 5della fue siempre un 20-35\% mayor que los de plántulas silvestres (Fig. 26C). Estos datos sugieren que el NO regula el tamaño del hipocotilo a través de la función de las DELLA. Sin embargo, incluso a las dosis más bajas de SNP utilizadas, alrededor de un cuarto del efecto del NO se ejerce a través de un mecanismo independiente de las DELLA. Este dato pone de manifiesto que las DELLA no son la única diana de la acción del NO en el control del crecimiento, lo que esta de acuerdo con la regulación transcripcional que ejerce el NO sobre PIF1, PIF3 y PIF4, propuesta anteriormente.

Para identificar el mecanismo por el cual el NO promueve la acumulación de las proteínas DELLA, se analizaron distintos niveles de regulación. En primer lugar, el incremento en proteínas DELLA, puede ser el resultado de la activación transcripcional de los genes que codifican las proteínas DELLA por NO. Pese a que se observó la acumulación de dichas proteínas en las líneas 35S:TAP-DELLA donde no existe un control transcripcional por NO ya que la expresión de las DELLA está dirigido por el promotor constitutivo 35S, decidimos medir los niveles de expresión de los genes que codifican las proteínas DELLA, ya que en plantas $p R G A: \because G F P-R G A$ el NO sigue teniendo el mismo efecto. La cuantificación de los transcritos mediante qPCR de hipocotilos de plántulas silvestres expuestas a NO no reveló ningún cambio en los transcritos de dichos genes (Fig. 27). 
A

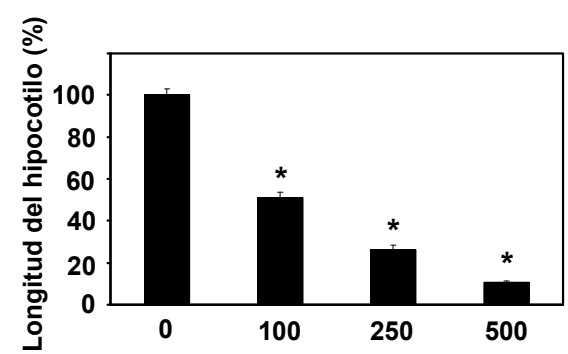

B

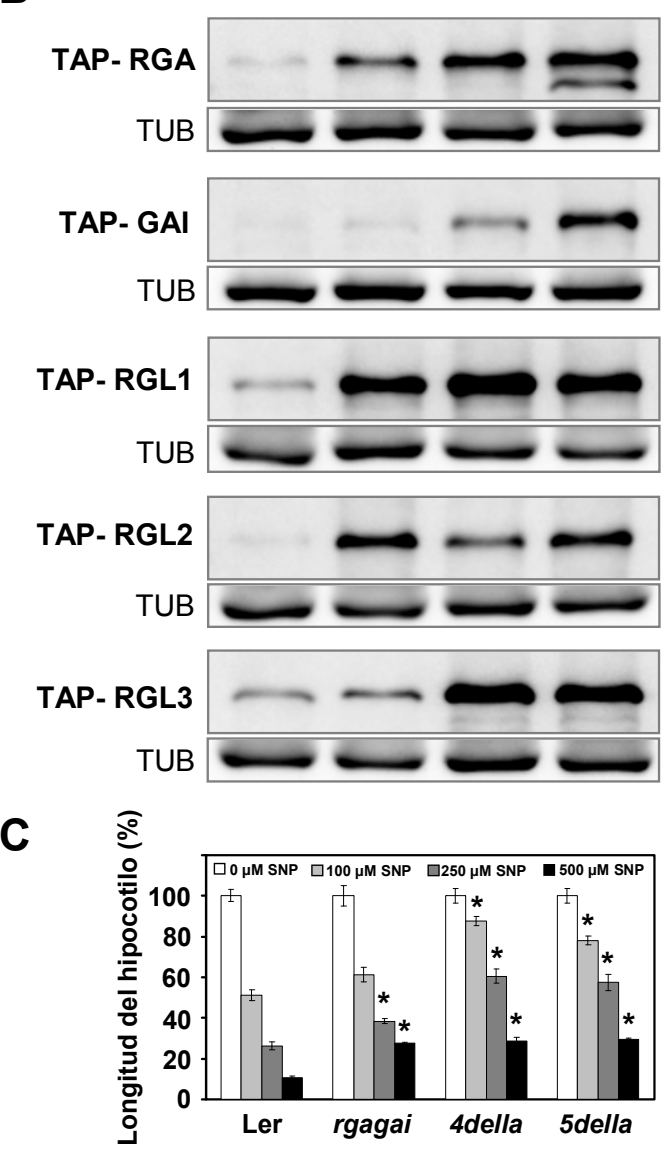

Figura 26. Efecto del NO en la elongación del hipocotilo y en el contenido en proteínas DELLA en luz roja.

Longitud del hipocotilo de plantas silvestres, Ler (A) y los mutantes rga-24gai-t6, cuádruple (4della) y quíntuple della (5della) (C) tratadas con las concentraciones de SNP indicadas, durante tres días. Los valores son medias de tres experimentos independientes \pm error estándar. B. Acumulación de las proteínas TAP-DELLA tras el tratamiento con las mismas concentraciones de SNP utilizadas en A. Se utilizaron anticuerpos anti-MYC para detectar las diferentes proteínas TAP-DELLA y anti-TUB para detectar tubulina como control de carga.

Tampoco se observaron cambios significativos en los transcritos de estos genes en el mutante deficiente en NO, nia1,2noal-2 cuando se comparó con plantas silvestres (Fig. 27). Solo se observó un cambio en la transcripción de $R G L 1$ en el triple mutante pero estaba aumentado y no reprimido como sería de esperar. Otra posibilidad que contemplamos fue que el NO estuviera regulando la biosíntesis o el catabolismo de GAs, de forma que la aplicación de NO resultara en niveles más bajos de GAs que no degradarían las proteínas DELLA, resultando en su acumulación o en la situación contraria en el caso del mutante nial,2noal-2. Se midieron los niveles de los transcritos de genes de la biosíntesis o de la degradación de GAs en hipocotilos de plántulas expuestas a NO o en el mutante nial,2noal-2 (Fig. 28). Sin embargo, pese a que encontramos alguna diferencia en la transcripción de algunos de estos genes no encontramos un efecto claro que explicara la exagerada acumulación de las proteínas DELLA en las diferentes líneas transgénicas 
analizadas, sugiriendo que el NO promueve la acumulación de las proteínas DELLA sin interferir con los niveles de GAs en Arabidopsis.
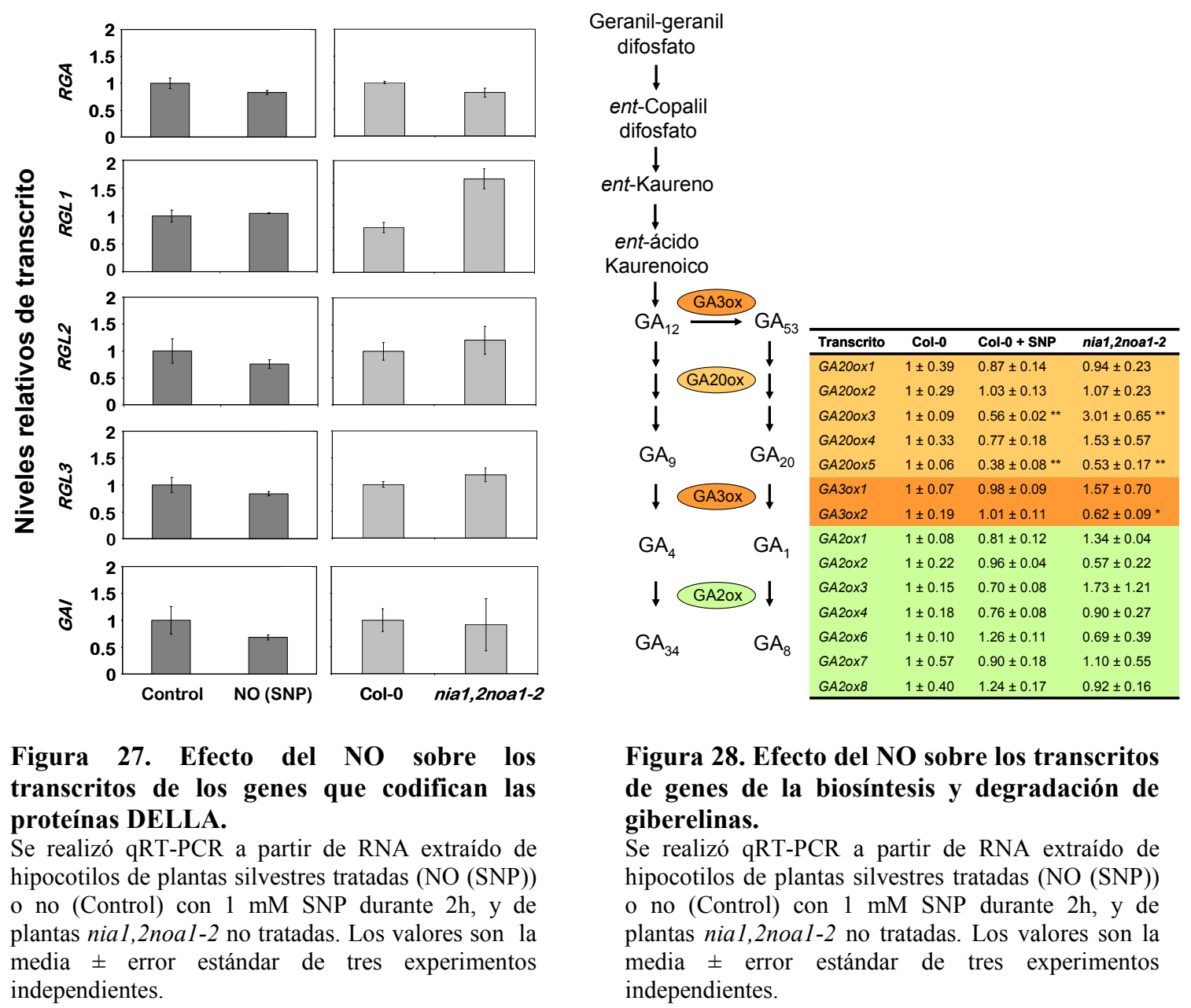

Figura 28. Efecto del NO sobre los transcritos de genes de la biosíntesis y degradación de giberelinas.

Se realizó qRT-PCR a partir de RNA extraído de hipocotilos de plantas silvestres tratadas (NO (SNP)) o no (Control) con $1 \mathrm{mM} \mathrm{SNP}$ durante $2 \mathrm{~h}$, y de plantas nial,2noal-2 no tratadas. Los valores son la media \pm error estándar de tres experimentos independientes.

La acumulación/degradación de las proteínas DELLA está controlada por el complejo GID1DELLA-SLY1 a través de un proceso en el que tras la percepción de las GAs por su receptor GID1, se reclutan las proteínas DELLA, y se ubiquitinan posteriormente por la E3 ubiquitin ligasa SLY1. Entonces, la proteína DELLA ubiquitinada es susceptible de ser degradada por el proteasoma., En este complejo existen diferentes componentes que podrían ser potenciales dianas de la regulación por NO. En primer lugar comprobamos que ni el tratamiento con NO ni la deficiencia en NO del mutante nial,2noal-2 provocaban una diferencia en la expresión de los genes GIDla, GIDIb, GIDIc, con la excepción de GIDIb que se regula por NO pero no puede explicar el fenotipo de acumulación de DELLAs (Fig. 29A). Sin embargo, al analizar el comportamiento de los dobles mutantes gidla,b; gidla,c y gidlb,c observamos que algunos de ellos no respondían a $\mathrm{NO}$ en el acortamiento del tamaño del hipocotilo, sugiriendo que estas proteínas estan de alguna forma regulando la repuesta a NO (Fig. 29C,E). En cambio, SLY1 se modula transcripcionalmente por NO de manera que el tratamiento con NO provoca una clara represión de dicho gen y la deficiencia de NO promueve su inducción (Fig. 29B). De acuerdo con 
esto, el mutante sly1-10 resultó menos sensible al NO en la reducción del tamaño del hipocotilo, mientras que la ganancia de función de $S L Y 1$ en el mutante sly-1D resultó en una sensibilidad algo más acentuada a NO (Fig. 29D, F). Estos datos sugieren que el NO regula la acumulación de las proteínas DELLA y su papel en el alargamiento del hipocotilo mediante la regulación de la expresión de $S L Y 1$.

A

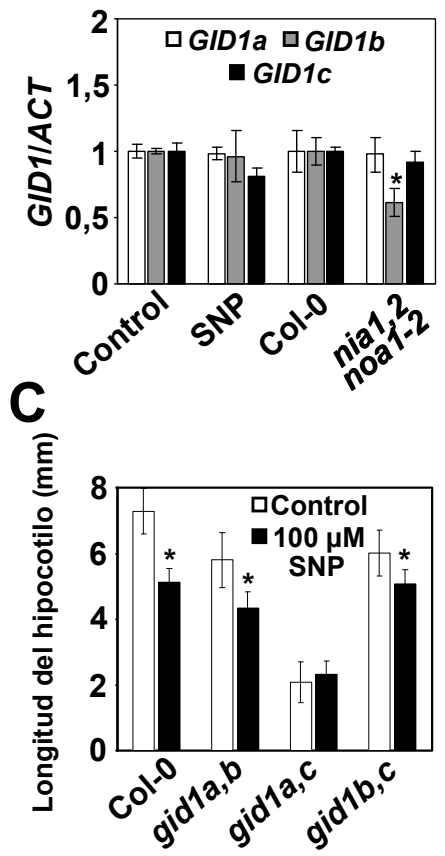

E

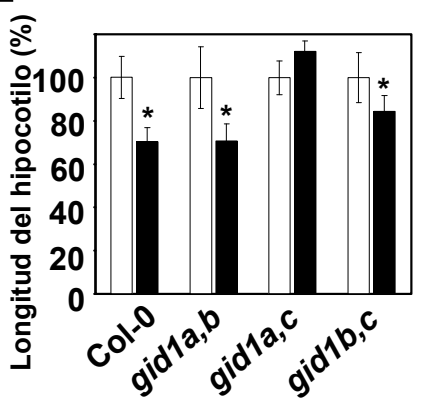

B
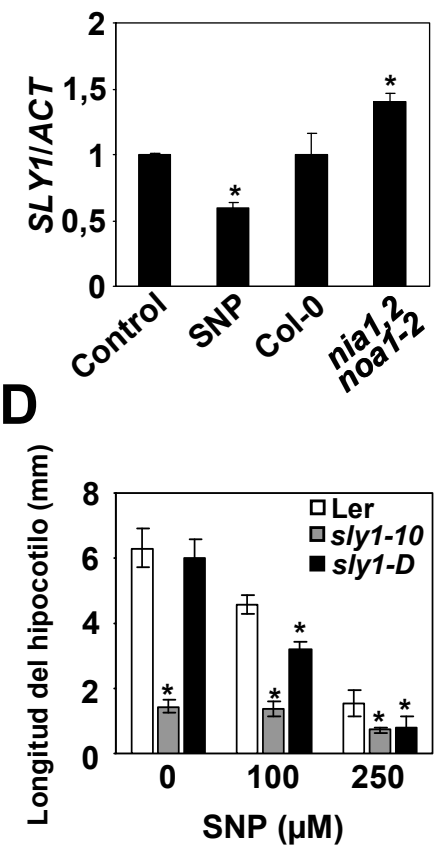

$\mathbf{F}$

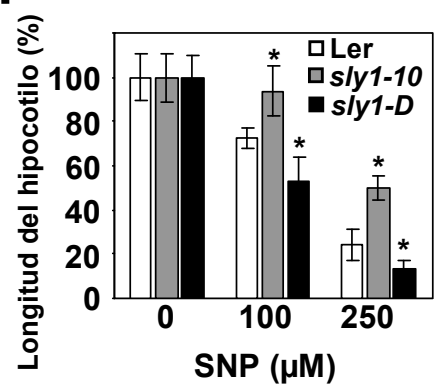

Figura 29. Conexión funcional entre el NO y los componentes de la señalización de las giberelinas GID1 y SLY1.

A y B. Análisis de los transcritos de genes GID1 y $S L Y 1$ en hipocotilos de plántulas silvestres tratadas (SNP) o no (Control) con 1 mM SNP, junto con los no tratados del mutante nial,2noal-2 y su fondo genético silvestre Col-0. Los valores son la media \pm error estándar de tres experimentos independientes. C y E. Longitud del hipocotilo total y relativa, respectivamente, de Col-0 y varias combinaciones de dobles mutantes gidl en plántulas de tres días no tratadas (barras blancas) y tratadas (barras negras) con $100 \mu \mathrm{M}$ SNP. D y F. Longitud del hipocotilo total y relativa, respectivamente, de Col-0 y la pérdida de función sly1-10 y la ganancia de función slyl-D, a las concentraciones de SNP indicadas. C-F. Los valores son la media \pm error estándar de tres experimentos independientes. Los asteriscos representan diferencias significativas con un p-valor $<0,05$ mediante test-t. 
La producción de NO responde a transiciones oscuridad-luz y es regulada negativamente por GAs

Para que el papel propuesto del NO tenga una relevancia en el proceso de des-etiolación, necesita de un apoyo fisiológico. Hemos estudiado si la transición de oscuridad a luz, que promueve el programa de des-etiolación, es acompañada por una producción de NO endógeno en Arabidopsis. Mediante la fluoresceína DAF-FM DA, se midieron los niveles de NO en plántulas silvestres en condiciones de oscuridad y una hora después de pasar las plántulas de oscuridad a luz roja,. Se detectaron niveles muy bajos de fluorescencia asociada a NO en las plántulas crecidas en oscuridad pero se vieron incrementados significativamente al pasar las plántulas a luz roja (Fig 30A). Sin embargo, este incremento en los niveles de NO no tuvo lugar en el mutante nial,2noal2 ni en el mutante $p h y B$ (Fig. 30A). De manera interesante, el mutante deficiente en GAs, gal-3, presentaba niveles de NO en oscuridad mayores que los detectados en plántulas silvestres (Fig. $30 \mathrm{~A}$ ), sugiriendo que tal vez las GAs ejercen una regulación negativa sobre los niveles de $\mathrm{NO}$ en el hipocotilo. Además, no se detectó un incremento en la acumulación de NO en el mutante gal-3 tras pasarlo a luz roja (Fig. 30A). Apoyando la idea de que las GAs controlan los niveles de NO, tanto plántulas silvestres como mutantes gal-3 presentaron una reducción de sus niveles de NO tras tratarlas con GAs (Fig. 30B). En cambio, el mutante gai-1D no alteró sus niveles endógenos de NO tras el tratamiento con GAs (Fig. 30B).

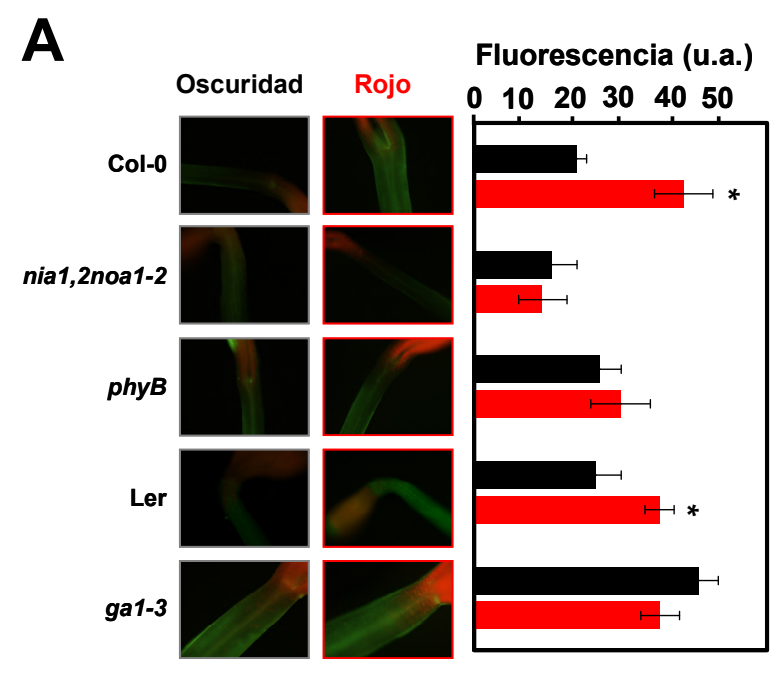

B

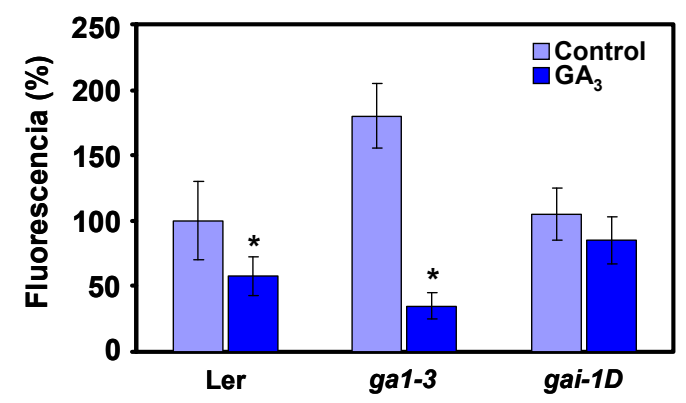

Figura 30. Niveles de NO en los hipocotilos de diferentes genotipos en condiciones de oscuridad y tras la transferencia a la luz.

A. Detección de NO en plántulas de 5 días crecidas en oscuridad (oscuridad) y tras pasar las plántulas $1 \mathrm{~h}$ a luz roja (Rojo). B. Niveles de NO en plántulas de Ler, gal-3 y gai-1D crecidas en oscuridad, tras tratar $\left(\mathrm{GA}_{3}\right)$ o no (Control) con $50 \mu \mathrm{M} \mathrm{GA}$ durante 2,5 horas. Los valores son relativos a lo detectados en el silvestre en condiciones control. El panel derecho de A y el panel B muestran la cuantificación de tres experimentos independientes como la media \pm error estándar. Los asteriscos indican diferencias significativas, $\mathrm{p}$-valor $<0,05$ comparando con los controles en oscuridad (A) o no tratados (B) mediante test-t. 


\section{DISCUSIÓN}

Las especies reactivas de oxígeno y nitrógeno tiene importantes papeles en la regulación del desarrollo de las plantas siendo características de transiciones del desarrollo (Gapper y Dolan 2006; Tsukagoshi et al., 2010). Estas moléculas tienen funciones documentadas regulando la adaptación a cambios en temperatura (Allakhverdiev et al., 2008) o luz (Li et al., 2009b), condiciones que regulan procesos del desarrollo como la germinación y el establecimiento (Bailly et al., 2008), la elongación del hipocotilo (Stavang et al., 2009), la floración (Ye et al., 2000; Kumar y Wigge 2010), la senescencia foliar (Jing et al., 2008) y la formación de tubérculos (Agrawal et al., 2008). Entre las especies reactivas producidas en respuesta a cambios ambientales, el NO ha sido el centro de atención durante los últimos años como una molécula señalizadora en respuestas tanto defensivas (Romero-Puertas et al., 2004; Wendehenne et al., 2004; Hong et al., 2008) como de desarrollo (He et al., 2004; Lopez-Bucio et al., 2006). Así, tanto las especies reactivas de oxígeno (ROS) como el NO han sido postulados como importantes reguladores del desarrollo (Foreman et al., 2003; Prado et al., 2004; Carol et al., 2005; Hu et al., 2005; Gapper y Dolan 2006; Tsai et al., 2007; Muller et al., 2009; Tsukagoshi et al., 2010) posiblemente por su conexión con la señalización de diferentes hormonas (Pagnussat et al., 2003; Garcia-Mata y Lamattina 2007; Liu et al., 2009b; Bahin et al., 2011). Se ha descrito que la aplicación de un donador de NO a plántulas etioladas de Arabidopsis promueve la des-etilación e inhibe la elongación del hipocotilo (Beligni y Lamattina, 2000). Además, un tratamiento térmico a $45^{\circ} \mathrm{C}$ da lugar a una fuerte producción de NO y a la concomitante inhibición del crecimiento del hipocotilo (Lee et al., 2008). Además, el mutante hot 5-1, afectado en una S-nitrosoglutatión reductasa que moviliza el aducto de NO del S-nitrosoglutatión, se mostró susceptible a altas temperaturas, acumuló mayores niveles de NO que plantas silvestres y presentó un fenotipo des-etiolado en oscuridad (Lee et al., 2008), siendo este fenotipo dependiente de la mayor acumulación de NO de este mutante (Lee et al., 2008). De acuerdo con esto, hemos encontrado que las plántulas del triple mutante, nial,2noal-2, que presentan una marcada reducción de los niveles de NO, tienen hipocotilos más largos en condiciones de iluminación con luz roja y no bajo condiciones de luz roja lejana o azul. Estos datos estan de acuerdo con los descritos para un mutante impedido en la activación de la expresión de NR/NIA (Lin y Cheng 1997). Además, tal y como se presenta en este capítulo, un mutante que acumula más NO presenta hipocotilos más cortos que el silvestre bajo las mismas condiciones (Fig. 21). Todas estas evidencias apuntan a un papel positivo del NO en la promoción de la fotomorfogénesis. Sin embargo no se conocía hasta el momento el mecanismo molecular por el que el NO regula la fotomorfogénesis.

La observación de que el triple mutante presentaba hipocotilos alargados únicamente en condiciones de iluminación con luz roja, y ya que el PHYB es el fotorreceptor principal que media 
la des-etiolación en luz roja (de Lucas et al., 2008), sugería en primera instancia, que el PHYB podría ser una diana del efecto del NO. Tras comparar los fenotipos del mutante $p h y B$ con los del mutante nial,2noal-2, y tras comprobar que, el triple mutante es capaz de producir una cantidad de proteína PHYB en oscuridad similar a la detectada en plantas silvestres y que el mutante phyB responde normalmente a NO, pensamos que la señalización dependiente de PHYB estaba alterada en el triple mutante. Esta hipótesis esta de acuerdo con los datos publicados anteriormente sobre el papel del segundo mensajero de NO, cGMP, en el control de la señalización del fitocromo relacionada con diferentes procesos como el desarrollo del cloroplasto (Bowler et al., 1994a, Bowler et al., 1994b). Es importante señalar que tras comparar los efectos de la aplicación de NO en la elongación del hipocotilo bajo condiciones de oscuridad o bajo iluminación con luz roja hemos encontrado esencialmente los mismos resultados (Fig. S1). Esto sugiere que el NO en oscuridad puede regular los mismos componentes que en luz roja. Existen diferentes componentes de señalización por debajo del PHYB, pero quizás su interacción con los factores de transcripción PIFs sea una de las más tempranas (Bae y Choi, 2008). El hecho de que el triple mutante presentara hipocotilos más largos y acumulara mayores niveles de antocianinas apuntaba a una mayor expresión de los genes PIF, particularmente de PIF3, es este mutante. Aunque HY5, otro componente esencial en la promoción de la fotomorfogénesis, esta también relacionado con la síntesis de antocianinas (Shin et al., 2007), no esperamos una mayor expresión de este factor de transcripción en el triple mutante, ya que ello llevaría al fenotipo opuesto de sus hipocotilos. Además, la reducida acumulación de PHYB en el triple mutante bajo condiciones de luz roja encaja muy bien con una mayor expresión de PIF3 en este mutante, debido al papel negativo descrito de PIF3 y PIF4 en la regulación de los niveles de PHYB (Leivar et al., 2008a; Jang et al., 2010). Hemos demostrado que la expresión de PIF3 junto a PIF1 y PIF4 es reprimida por NO encontrándose, por tanto, inducida en el mutante NO-deficiente. De manera interesante, se ha descrito la interacción entre HY5, HYH y PIF4 en la regulación de la activación por luz de NR2/NIA2 (Jonassen et al., 2009a; Jonassen et al., 2009b). Estos datos sugieren la existencia de una regulación entre NR/NIA y los PIFs como potencial mecanismo de integración del desarrollo por luz y NO.

Aunque se ha propuesto que el NO puede regular el tamaño del hipocotilo (Beligni y Lamattina 2000; Tonon et al., 2010) no se había descrito ningún mecanismo molecular que lo explicase. Hemos identificado los PIFs como importantes reguladores de los fenotipos de la elongación del hipocotilo presentes en plantas deficientes en NO. Además, hemos encontrado que el mutante pifQ es casi completamente insensible a la aplicación de NO en la inhibición de la elongación del hipocotilo. Sin embargo, ni pif3 ni pif4 mostraron este fenotipo de resistencia al NO, probablemente debido a la redundancia de los diferentes PIF en el control del tamaño del hipocotilo mediado por NO. De todas formas, la actividad de los PIF está finamente regulada mediante heterodimerización (Hornitschek et al., 2009) y/o a través de la interacción con otras 
proteínas, como las DELLA, inhibiendo su actividad (de Lucas et al., 2008; Feng et al., 2008). La regulación negativa de la función de los PIF por NO (Fig. 24A) está acompañada de una acumulación de las proteínas DELLA (Fig. 25). Se dispone de claras evidencias que prueban la interacción física de PIF3 y PIF4 con diferentes miembros de la familia DELLA, como RGA y GAI, resultando en la reducción de su capacidad de activar la expresión de sus genes diana (de Lucas et al., 2008; Feng et al., 2008; Gallego-Bartolomé et al., 2010). Tras la transición de oscuridad a luz, la producción de NO da lugar a la represión de la transcripción de algunos PIFs y a un incremento en los niveles de DELLAs, resultando en un conjunto muy pequeño de PIFs que puedan mantener la escotomorfogénesis. Pero, ¿cual es el mecanismo por el que el NO provoca la acumulación de las DELLA? Primero, comprobamos que las plántulas tratadas con NO eran capaces de degradar las proteínas DELLA en respuesta a la aplicación con GAs (Fig. 25). De manera sorprendente, las plantas tratadas con NO degradaban las DELLA de manera más eficiente en respuesta a GAs que las plantas control no tratadas (Fig. 25). Este mecanismo, lejos de ser inusual, opera en otras condiciones donde tiene lugar una acumulación exagerada de DELLAs debida a una expresión alterada de genes clave (Silverstone et al., 2007; Willige et al., 2007; Richter et al., 2010), o a la inhibición de la biosíntesis de giberelinas mediante PAC (Muangprom et al., 2005). Tras realizar ensayos in vitro podemos proponer que esto se debe a un mecanismo de degradación independiente del proteasoma (Fig. 25). Entonces, exploramos la posibilidad de que el NO regulara la transcripción de los genes que codifican las proteínas DELLA (Fig. 27). Sin embargo, el NO no afectó a ninguno de estos genes, ni en tratamientos exógenos con SNP, ni en el mutante deficiente en NO (Fig. 27). Eventualmente, el NO podría controlar la biosíntesis y el metabolismo de GAs para modular los niveles de DELLA. Tras un extensivo análisis de la expresión de los genes de la biosíntesis, GA20ox y GA3ox y del catabolismo, GA2ox, de giberelinas, solo el gen GA20ox3 cumplió los requisitos para poder ser una diana del $\mathrm{NO}$ en el control de la homeostasis de GAs, ya que se regula negativamente por NO exógeno y esta inducido en el mutante nial,2noal-2 (Fig. 28). Sin embargo, podemos anticipar que cambios en los contenidos de GAs, en el triple mutante o tras el tratamiento con NO, en el caso en el que los hubiera, deberían estar restringidos a un órgano, tejido o a un conjunto de células limitado, pero no a toda la plántula, ya que las plantas nial,2noal-2 no presentan ningún fenotipo general característico de plantas que sobreproduzcan GAs, sino más bien al contrario. Las plantas nia1,2noal-2 son semi-enanas y presentan una menor longitud del tallo produciendo una menor cantidad de semillas con una dormición muy marcada. Una mayor acumulación de GAs en el hipocotilo del triple mutante podría explicar su fenotipo de hipocotilos elongados y la menor acumulación de DELLAs, pero realizar estas medidas es técnicamente muy difícil a si que se deberían desarrollar nuevas tecnologías o sensores para poder completar este propósito en un futuro. 
A pesar del posible papel del NO en la regulación de la homeostasis de GAs, el NO ciertamente regula la señalización de GAs a través de la modulación de la abundancia de las DELLA (Fig. 25 y 26). Ya que los niveles de acumulación de las DELLA están regulados a través de su degradación por la ruta ubiquitina-proteasoma dependiente del complejo GID1-SCF ${ }^{\text {SLY1, }}$ exploramos si este módulo era una de las dianas de la regulación por NO. Primero, comprobamos que el NO no regula la expresión de los genes GIDIa, GIDIb y GIDIc, que codifican las diferentes isoformas del receptor GID1 de Arabidopsis. Sin embargo, el doble mutante gidla,c, afectado en las isoformas de GID1 más relacionadas con el control del tamaño del hipocotilo (Griffiths et al., 2006; Stavang et al., 2009), mostró un fenotipo de resistencia al NO (Fig 29). En segundo lugar, la represión de $S L Y 1$ por NO y la inducción de este gen encontrada en el mutante nial,2noal-2 (Fig. 29), puede explicar muy bien el control de la acumulación de las proteínas DELLA por NO. Además, el mutante slyl-10 fue parcialmente insensible a la aplicación de NO en condiciones de luz roja (Fig. 10). El hecho de que mutantes en los genes que codifican las proteínas DELLA, los receptores GID1 y la E3 ubiquitin ligasa SLY1 se comporten como parcialmente insensibles a NO, sugiere claramente que el complejo GID1-DELLA-SLY1 es una diana de la regulación del tamaño del hipocotilo mediado por NO. Resulta interesante que el mutante sly 1-10, respondió de forma diferente a la aplicación de $\mathrm{NO}$ en condiciones de oscuridad o de iluminación con luz roja (Fig. 29). El hecho de que el mutante sly1-10 responda como plántulas silvestres a la aplicación de NO en oscuridad pero no en luz roja sugiere que el control transcripcional de $S L Y 1$ por NO es funcional sólo en condiciones de luz roja. En cambio, los genes $P I F$ s parecen ser las dianas más importantes del NO en oscuridad. El mutante pifQ es casi insensible a la aplicación de NO, sugiriendo que los PIF deben tener un papel clave en la regulación negativa que ejerce el NO sobre el módulo básico de señalización de GAs. La interacción funcional negativa entre el $\mathrm{NO}$ y las GAs en el control de la fotomorfogénesis es potenciada por el efecto negativo de las GAs sobre la biosíntesis de NO, como se demostró por la mayor acumulación de NO en plántulas gal-3, que puede ser revertida mediante la aplicación de $\mathrm{GA}_{3}$ (Fig 30).

Con todos estos datos se puede proponer un modelo integrando la función del NO, GAs, DELLAs y PIFs en el control de la fotomorfogénesis, como se muestra en la figura 31. La transición de oscuridad a luz da lugar a una reducción en la biosíntesis de GAs y a un incremento en los niveles de NO. Esta situación provoca una mayor acumulación de las proteínas DELLA como resultado de una menor interacción funcional del complejo GID1-GA-DELLA-SLY1. Estos niveles altos de DELLAs permiten su interacción con factores de transcripción, como los PIF, cuya transcripción se reprime por NO. El papel de las DELLA secuestrando estos factores de transcripción e impidiendo la activación de sus genes diana junto con la represión transcripcional de los PIFs ejercida por el NO, dará lugar al bloqueo de la elongación del hipocotilo, entre otros procesos característicos de la fotomorfogénesis. En el mutante nia1,2noal-2, los niveles de NO 
son muy bajos, minimizándose el control negativo sobre la expresión de los PIFs. Al mismo tiempo, la ubiquitinación de las DELLA mediada por SLY1 y su posterior degradación debe estar aumentada en condiciones de baja acumulación de NO, dando lugar a una menor cantidad de DELLAs. Como resultado, el mayor contenido en PIFs libres y/o su función incrementada en el mutante nial,2noal-2, podría ser responsable de los hipocotilos alargados que presenta este mutante en condiciones de iluminación (Fig. 21).

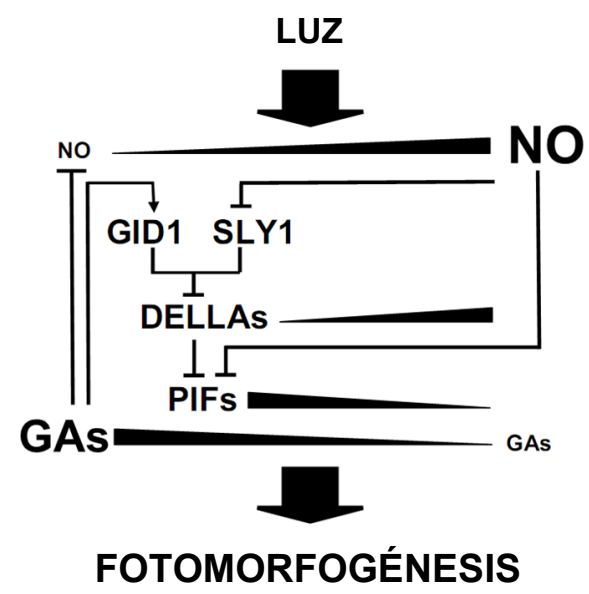

Figura 31. Esquema integrando las funciones antagonistas del NO y las GAs en el control de la fotomorfogénesis a través del balance entre las DELLAs y los PIFs. 


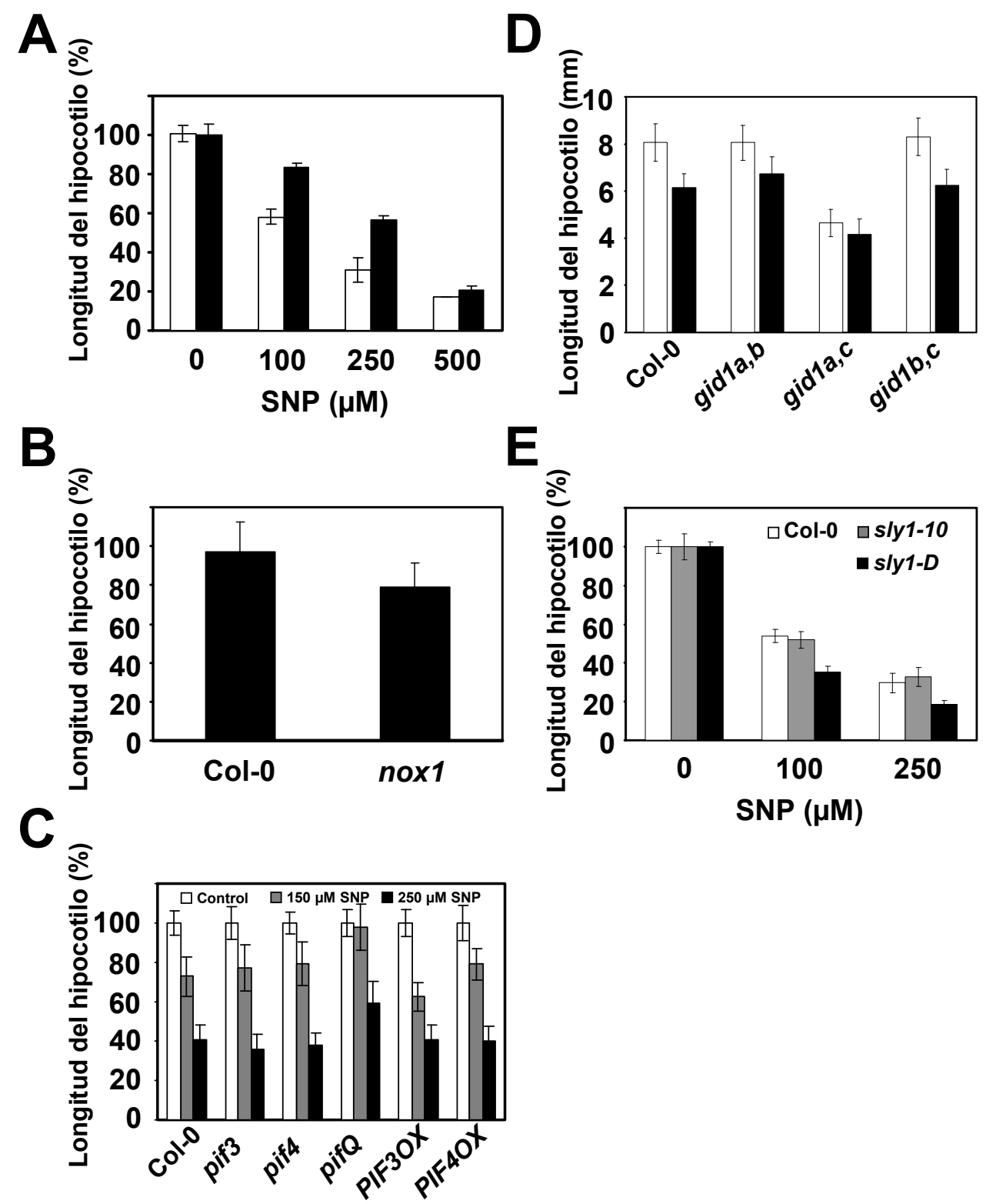

Figura S1. Experimentos correspondientes a las figuras 21, 24, 26 y 29 realizados en oscuridad. 

CAPÍTULO 4: MODO DE ACCIÓN DEL ÓXIDO NÍTRICO: NITRACIÓN DE PROTEÍNAS 


\section{ACCIÓN REGULADORA DEL ÓXIDO NÍTRICO A TRAVÉS DE LA NITRACIÓN DE PROTEÍNAS EN Arabidopsis thaliana}

\section{INTRODUCCIÓN}

El NO, a pesar de su naturaleza reactiva, actúa como molécula señalizadora en numerosos procesos biológicos de organismos pertenecientes a reinos tan dispares como bacterias, hongos, animales y plantas. Se ha comprobado que el NO juega un papel importante durante todo el ciclo de vida de las plantas. Esto lo hace, en gran medida, a través de su interacción con las diferentes hormonas y reguladores del crecimiento (Hu et al., 2005; Lopez-Bucio et al., 2006; Chen et al., 2010b; Romera et al., 2011). El NO participa en la señalización de hormonas tan importantes para el desarrollo de las plantas como las auxinas, las citoquininas, el etileno, el ácido abscísico y las giberelinas, entre otras (Bethke et al., 2004b; Jovanovic et al., 2005; Lindermayr et al., 2006; Tun et al., 2008; Romanov et al., 2008; Flores et al., 2008). Por otro lado, estas mismas hormonas promueven la síntesis de $\mathrm{NO}$, lo que representa un punto adicional de control sobre la señalización de hormonas (Tun et al., 2001; Neill et al., 2002a; Pagnussat et al., 2002; Pagnussat et al., 2003; Bright et al., 2006; Zottini et al., 2007; Kolbert et al., 2008b; Kolbert y Erdei 2008). Si bien se conocen determinados ejemplos de la regulación de procesos fisiológicos de dichas hormonas que tienen como intermediario el NO, se desconoce, en gran medida, su modo de acción.

El NO, a diferencia de las hormonas y otros reguladores del crecimiento, actúa a través de dos niveles de regulación posiblemente conectados, la regulación de la expresión génica y la modificación post-traduccional de proteínas. Esto convierte al NO en un regulador muy versátil (Bruckdorfer 2005). Es capaz de interaccionar directamente con las proteínas modificando tanto su actividad, su localización, su estabilidad o su interacción con otras proteínas, y, como consecuencia de estas modificaciones o independientemente de las mismas, es capaz de alterar el transcriptoma y regular diferentes vías de señalización. Esta característica supone un importante punto de control sobre la modulación de las funciones celulares ya que las proteínas son las encargadas de realizar las diferentes tareas que resultan en un correcto desarrollo del organismo. Si bien se han centrado muchos esfuerzos en comprender como se regula la transcripción de los diferentes genes que las codifican, existen otros niveles de control sobre las proteínas, que pueden llevar a cambios en su localización, estabilidad o actividad. Estos niveles de control, al ser posteriores al de la transcripción de los genes y a su traducción, tienen un impacto más directo y rápido sobre la función de estas proteínas.

Para que una modificación post-traduccional pueda actuar como un elemento de señalización fisiológicamente relevante debe cumplir determinados criterios. La modificación debe ser específica y reversible, preferiblemente mediante una reacción enzimática. Su formación debe 
tener lugar en una escala de tiempo fisiológica, a menudo por acción de una reacción enzimática,. Finalmente, la modificación debe resultar en un cambio de la actividad de la diana, ya sea activándola o inactivándola (Gow et al., 2004). El ejemplo clásico de modificación posttraduccional es la fosforilación de proteínas ya que ocurre en secuencias específicas, su formación es catalizada por quinasas y su eliminación es favorecida por fosfatasas (Krebs y Fischer 1964; Fischer y Krebs 1966). Así mismo, la fosforilación puede dar lugar a la activación o la inhibición de la actividad o la función de la proteína diana (Krebs y Fischer 1964; Fischer y Krebs 1966).

Gracias a los avances realizados en modelos biológicos diferentes a las plantas, está bien documentado que el NO es un mediador de diferentes modificaciones post-traduccionales (Gow et al., 2004). Estas modificaciones son la unión a centros metálicos de las proteínas, la nitrosilación de grupos tiol y amina, la nitración de residuos de tirosina, triptófano y fenilalaninas, así como la oxidación de grupos tiólicos o de tirosinas (Gow et al., 2004). No obstante, por su posible efecto en señalización, han sido dos las modificaciones post-traduccionales más estudiadas en modelos animales: la nitrosilación de cisteinas, que produce S-nitrosotioles y la nitración de tirosinas, que da lugar a nitrotirosinas.

\section{Nitrosilación de cisteinas (S-nitrosilación)}

Debido a su capacidad redox, el NO puede reaccionar con diferentes regiones nucleofílicas de las proteínas que incluyen aminas, anillos aromáticos, alcoholes y azufre reducido (tioles) (Gow et al., 2004). Si bien este tipo de reacción ha sido considerada históricamente como tóxica, recientemente ha pasado a centrar la atención de diferentes grupos de investigación por su posible relevancia fisiológica. Desde que se definió la formación de nitrosotioles (SNO) mediante la reacción del NO con el grupo tiol de la cisteína (Stamler et al., 1992c; Stamler et al., 1992a; Stamler et al., 1992b), han sido descritas numerosas proteínas susceptibles de este tipo de modificación. Estas proteínas cubren un rango amplio de actividades, incluyendo quinasas, canales iónicos, factores de transcripción, proteínas estructurales y proteasas entre otras (Stamler et al., 2001). La reciente caracterización de esta modificación post-traduccional ha revelado que cumple todos los requisitos para ser considerada como un componente de señalización relevante en condiciones fisiológicas, ya que tiene lugar en motivos consenso de las proteínas (Stamler et al., 1997), es favorecida por la actividad de proteínas conocidas, como la ceruloplasmina y la hemoglobina (Gow y Stamler 1998; Inoue et al., 1999), puede ser reversible por la acción de SNO reductasas (Liu et al., 2001) y, finalmente, su impacto sobre las proteínas se traduce tanto en su activación como en su inhibición (Lei et al., 1992; Kim et al., 1999; Kim 1999; Sun et al., 2001). Por tanto, se ha propuesto que la S-nitrosilación representa un modo de señalización fisiológicamente relevante tanto en plantas como en animales (Gupta 2011). 
La identificación de proteínas que sufren este tipo de modificación y la caracterización de los procesos controlados por las mismas son escasos en el campo de la biología vegetal, ya que es un tema que ha sido abordado recientemente. El análisis global de proteínas mediante técnicas proteómicas ha identificado un conjunto relativamente amplio de dianas susceptibles de ser nitrosiladas en Arabidopsis thaliana (Lindermayr et al., 2005; Romero-Puertas et al., 2008). Entre éstas, se incluyen proteínas que actúan tanto en señalización como en la regulación del metabolismo central (Lindermayr et al., 2005; Romero-Puertas et al., 2008). Ha sido comprobado que la nitrosilación de la metionina adenosiltransferasa reduce la actividad del enzima afectando negativamente a la síntesis de etileno (Lindermayr et al., 2006), y que la nitrosilación de la gliceraldehido-3-fosfato deshidrogenasa resulta en una inhibición del enzima y del metabolismo del carbono (Holtgrefe et al., 2008; Palmieri et al., 2010). También se ha descrito un importante papel de esta modificación post-traduccional en situaciones de estrés, especialmente en el establecimiento de la respuesta inmune. Así, la nitrosilación de AtSABP3 impide la unión del ácido salicílico (SA) a esta proteína y su correcta señalización, bloqueando la activación de la respuesta a patógenos dependiente de SA (Wang et al., 2009b). Además, la nitrosilación de NPR1, un regulador clave en la respuesta inmune en plantas, provoca la oligomerización de esta proteína impidiendo su entrada al núcleo y su posterior activación de los genes de respuesta a patógenos necesaria para establecer la defensa frente a diferentes patógenos (Tada et al., 2008). Sin embargo, el tratamiento con un donador de NO promueve la entrada de NPR1 al núcleo y la nitrosilación de NPR1, así como la del factor de transcripción TGA1, incrementando tanto la afinidad entre estas dos proteínas para la formación de dímeros, como la afinidad del factor de transcripción por sus secuencias dianas en el DNA (Lindermayr et al., 2010). Estos estudios confirman la posibilidad de que el NO regule procesos de defensa dependientes de SA mediante la nitrosilación de proteínas clave (Gupta 2011). También ha sido descrita la nitrosilación de otros factores de transcripción, como AtMYB2, con un importante papel en la señalización de ABA, aunque en este caso, la nitrosilación de este factor de transcripción impide su unión a los promotores de sus genes diana, resultando en un papel negativo del NO en la señalización del ABA (Serpa et al., 2007).

\section{Nitración de tirosinas (Y-nitración)}

Además de la nitrosilación de cisteinas, la nitración de tirosinas es la segunda modificación post-traduccional mediada por NO más estudiada en biología debido a su relación con procesos autoinmunes y neurodegenerativos en modelos animales y con la respuesta a estrés en plantas y otros organismos (Reynolds et al., 2007; Lee et al., 2008). 
<smiles>[Z]Cc1ccc(O)c(I)c1</smiles>

Tirosina

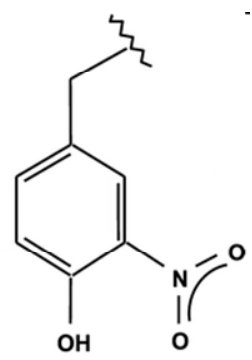

3-Nitrotirosina (3-nitroY
Figura 32. Diagrama representando la posición de la nitración en el anillo aromático de la tirosina.

La nitración de tirosina es una modificación covalente que resulta tras la adición de un grupo nitro $\left(\mathrm{NO}_{2}\right)$ en uno de los dos carbonos orto equivalentes del anillo aromático de los residuos de tirosina (Ischiropoulos 2003) (Fig.1), donde el NO actúa como fuente de nitrógeno (Ischiropoulos 1998). Las rutas químicas que dan lugar a la nitración de los residuos de tirosina, tanto in vitro como in vivo, han indicado que varias especies nitrantes como el dióxido de nitrógeno, el peroxinitrito o el ácido nitroso, pueden ser generadas in vivo tanto de forma simultánea como a diferentes tiempos dependiendo del tipo celular y el estímulo (Ischiropoulos 2003; Gaupels et al., 2011). Una vez generadas estas especies reactivas del nitrógeno (RNS), la nitración de proteínas puede ser producida tanto enzimática, como espontáneamente. Una gran abundancia de evidencias sugiere que la mieloperoxidasa, la peroxidasa eosinófila, la mioglobina y los citocromos P450 catalizan la oxidación de nitrito a dióxido de nitrógeno que es capaz de nitrar residuos de tirosina (van der Vliet et al., 1997; Wu et al., 1999; Brennan et al., 2002). Además, la mieloperoxidasa puede catalizar la nitración de proteínas por peroxinitrito, el producto de reacción entre el $\mathrm{NO}$ y el superóxido (Floris et al., 1993).

Por otro lado, la nitración no enzimática de tirosinas incluye los intermediarios de la reacción entre el peroxinitrito y el dióxido de carbono (Fig. 2) (Gow et al., 1996; Lymar et al., 1996) y la acidificación del nitrito que tiene como producto el ácido nítrico, un agente capaz de nitrar residuos de tirosina (Knowles et al., 1974). Tanto la nitración enzimática como la no enzimática son procesos suficientemente rápidos como para considerar que pueden producirse en una escala de tiempo fisiológica (Ischiropoulos 2003).

Los resultados de estrategias proteómicas, al igual que el desarrollo de numerosas técnicas analíticas e inmunológicas, han revelado que la nitración de tirosinas está limitada a un grupo reducido de proteínas (Gole et al., 2000; Aulak et al., 2001; Turko et al., 2003). La nitración de proteínas es una modificación post-traduccional poco frecuente (de 1 a 5 nitrotirosinas por cada 10000 residuos de tirosina), lo que sugiere que esta modificación es muy específica (Radi 2004). Aunque la proximidad de estas proteínas al sitio de generación de RNS es parte de la selectividad de este proceso, la nitración in vivo de proteínas abundantes y solubles como la actina (Aslan et al., 2003) sugiere la existencia de un mecanismo bioquímico y biofísico adicional que explique la selectividad de la nitración de determinadas proteínas (Ischiropoulos 2003). 


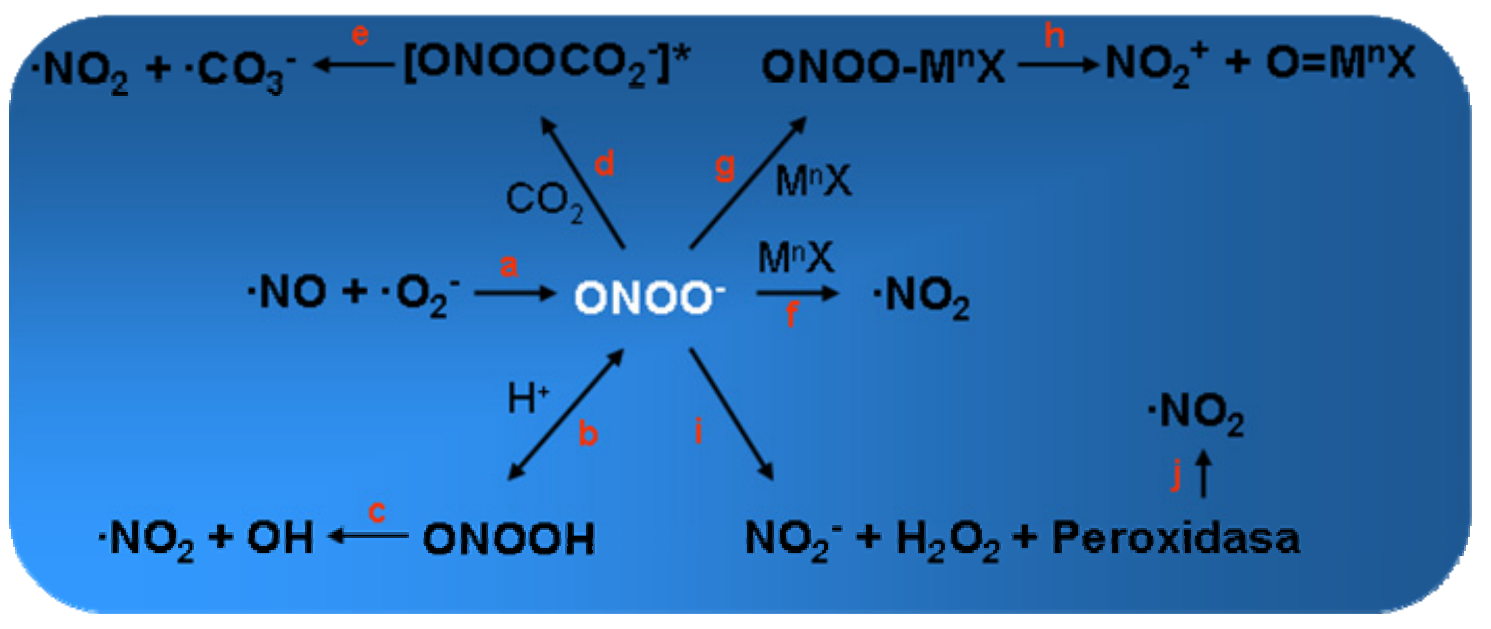

Figura 33. Rutas de nitración dependientes de peroxinitrito (ONOO־).

Adaptado de Reynolds et al., 2007. El $\mathrm{ONOO}^{-}$es generado tras la reacción de $\cdot \mathrm{NO}$ con $\cdot_{2}^{-}$(esquema a). Una vez formado, el $\mathrm{ONOO}^{-}$puede dirigir reacciones de oxidación de uno o dos electrones que resultan en la formación de intermediarios reactivos (b-j). En la mayoría de casos, la nitración de proteínas tiene lugar a través de un mecanismo de combinación de radicales libres por el que un radical tirosilo (·Tyr) se combina con $\cdot \mathrm{NO}_{2}$ para formar 3-nitroY. Sin embargo, a través de un mecanismo no radicalario, un metal de transición $\left(\mathrm{M}^{\mathrm{n}} \mathrm{X}\right)$-ONOO se descompone para formar el ión nitronio $\left(\mathrm{NO}_{2}^{+}\right)$. Este ión puede atacar directamente residuos de tirosina $(\mathrm{g}, \mathrm{h})$.

De forma homóloga a la fosforilación, se ha intentado determinar la existencia de secuencias en las proteínas que favorezcan su nitración (Elfering et al., 2004; Liu et al., 2011). Sin embargo, hasta la fecha, no hay evidencias claras que prueben la existencia de una única secuencia o de secuencias consenso requeridas para la nitración de tirosinas. Un mecanismo más probable para la explicación de la selectividad de la nitración de tirosinas puede ser la presencia de microambientes en la estructura secundaria o terciaria de la proteína que favorezcan su modificación. Así, la presencia de la tirosina diana en la proximidad de una carga negativa y su orientación expuesta al solvente, son dos características consistentes en muchos de los sitios de nitración descritos hasta la fecha (Ischiropoulos 2003). Sin embargo, se requiere del análisis estructural de mutaciones puntuales en dichas proteínas para establecer la importancia de estas características en la selectividad de la nitración de determinados residuos de tirosina.

En cuanto a la reversibilidad del proceso de nitración existen evidencias que implican diferentes procesos que dan lugar a la eliminación de la nitración de la proteína o de la proteína en sí. Las proteínas nitradas pueden volver a su estado normal mediante una actividad denominada denitrasa, que elimina el grupo nitro de la tirosina sin degradar o hidrolizar la proteína. Este tipo de actividad ha sido detectada en extractos de diferentes tejidos y organismos y es sensible a altas temperaturas, a tripsina y se mantiene tras pasar el extracto por filtros de $10 \mathrm{KDa}$, indicando una posible naturaleza proteica de la actividad (Kamisaki et al., 1998; Kuo et al., 1999; Schopfer et al., 2003; Irie et al., 2003). Sin embargo, la enzima o enzimas implicadas en dicha actividad son todavía desconocidas. 
Alternativamente, las proteínas nitradas son detectadas y eliminadas mediante la acción de diferentes proteasas o por la activación de la ubiquitinación y posterior degradación de proteínas por el proteasoma (Ischiropoulos y al-Mehdi 1995; Souza et al., 2000; Kotamraju et al., 2003). Además, la persistencia de la forma nitrada de determinadas proteínas da lugar a una respuesta inmune en modelos animales. Anticuerpos frente a estas proteínas modificadas y no frente a las no modificadas son generados por el organismo para su posterior procesamiento. Recientemente, se ha demostrado que algunos péptidos nitrados desencadenan una fuerte respuesta inmune en ratones incapaces de establecer el mismo tipo de respuesta frente a los péptidos nativos (Birnboim et al., 2003). Estos hechos sugieren que la nitración de proteínas puede inducir una respuesta inmune frente a proteínas del propio organismo, teniendo una influencia importante sobre los desórdenes autoinmunes e inflamatorios.

Por otro lado, el efecto más estudiado de la nitración es la modulación de la actividad y/o función de las proteínas diana. Ha sido descrito extensamente que la nitración es capaz tanto de reducir como de incrementar la actividad de diferentes proteínas (Fujita et al., 2009; Zaragoza et al., 2009; Sharov et al., 2009; Curry-McCoy et al., 2009; Zhou et al., 2009; Xu et al., 2009; Fujisawa et al., 2009; Barbosa-Sicard et al., 2009), así como su localización (Yakovlev et al., 2010) o su interacción con otras proteínas (Kasina et al., 2005; Mallozzi et al., 2009; Li et al., 2010), representando un mecanismo muy eficiente en el control de la señalización celular. Además, puesto que la nitración puede tener lugar de manera espontánea, es un mecanismo muy rápido de respuesta y adaptación de la célula que no requiere de transcripción y traducción de proteínas.

En conjunto, la nitración de tirosinas parece ser un proceso específico que puede tener lugar a través de una amplia variedad de mecanismos bajo una escala de tiempo fisiológicamente relevante. Además, la identificación de la actividad denitrasa abre la posibilidad a la reversibilidad de este proceso. Estas características junto al indudable impacto sobre la actividad de las proteínas sugiere que se trata de una modificación post-traduccional con relevancia en la señalización de procesos fisiológicos.

\section{Nitración de proteínas en plantas}

Como ocurre con la nitrosilación de proteínas, gran parte de la información acerca de la nitración de tirosinas ha sido obtenida en modelos animales. Sin embargo, recientemente, se han descrito diferentes trabajos enfocados a caracterizar este tipo de modificación en plantas (Valderrama et al., 2007; Romero-Puertas et al., 2007; Corpas et al., 2008; Chaki et al., 2009b; Chaki et al., 2009a; Bechtold et al., 2009; Cecconi et al., 2009; Corpas et al., 2009). Parece que las hemoglobinas de plantas pueden facilitar la nitración in vitro de proteínas tal como ocurre en modelos animales (Sakamoto et al., 2004). De la misma forma, la nitración de proteínas ocurre en 
respuesta a situaciones de estrés o tras la aplicación de peroxinitrito en plantas (Saito et al., 2006; Valderrama et al., 2007; Chaki et al., 2009a; Cecconi et al., 2009). Por otro lado, el número de proteínas nitradas identificadas en plantas es mucho menor que en modelos animales (Corpas et al., 2007). Basándose en la detección por Western-blot de proteínas separadas en geles bidimensionales mediante un anticuerpo que detecta 3-nitrotirosina y la posterior identificación de los proteínas inmunoreactivas, se han identificado 12 proteínas de Arabidopsis que ven incrementado su patrón de nitración en respuesta a la bacteria fitopatógena Pseudomonas syringae (Cecconi et al., 2009) y 21 proteínas de girasol que sufren el proceso de nitración bajo condiciones fisiológicas en ausencia de estrés (Chaki et al., 2009b). La gran mayoría de las proteínas identificadas regulan procesos del metabolismo como la RuBisCO, la Fructosas bifosfatasa y la Sadenosyl-homocisteina hidrolasa. Proteínas similares a 14-3-3 y calmodulina son las únicas identificadas con una potencial función en señalización (Chaki et al., 2009b). Curiosamente, ninguna de las proteínas nitradas identificadas tras la infección por Pseudomonas syringae se encuentra enmarcada dentro de las proteínas de respuesta a estrés (Cecconi et al., 2009), lo que se podría esperar tras el bien establecido papel del NO y de las especies reactivas de nitrógeno causantes de la nitración en las interacciones planta-patógeno (Delledonne et al., 1998; Saito et al., 2006; Besson-Bard et al., 2008a; Chaki et al., 2009a). Desgraciadamente, debido al reducido número de proteínas identificadas, no podemos especular acerca de la función de las proteínas nitradas en plantas y si estas regulan mayoritariamente el metabolismo, la señalización o la respuesta a estrés en modelos vegetales. Además, la falta de la identificación, mediante espectrometría de masas, del sitio de nitración en estas proteínas, es decir, la tirosina o tirosinas que sufren la modificación, solo nos permite hablar de estas proteínas como posibles proteínas nitradas y nos hace interpretar con cautela los resultados obtenidos mediante estos métodos.

Debido a la poca información acerca de la dianas de nitración en plantas, de la ausencia de identificación inequívoca de sitios de nitración, y del escaso análisis del impacto de la nitración de estas proteínas sobre su actividad, hemos desarrollado un método para el aislamiento, identificación y caracterización de proteínas nitradas en Arabidopsis. 


\section{RESULTADOS}

\section{Detección y purificación de proteínas nitradas in vivo en Arabidopsis}

La nitración de proteínas en un fenómeno común en diferentes sistemas biológicos que tiene lugar de forma dependiente de la producción de NO (Bruckdorfer et al., 2005). En animales, la nitración tiene lugar preferentemente en la posición 3 del anillo aromático de los residuos de tirosina $(\mathrm{Y})$ y puede ser detectada mediante anticuerpos contra 3-nitrotirosina (3-nitroY) (Franze et al., 2004). Hemos encontrado proteínas en extractos crudos de Arabidopsis que reaccionan con el anticuerpo anti 3-nitroY en todo el rango de pesos moleculares (Fig. 34A).

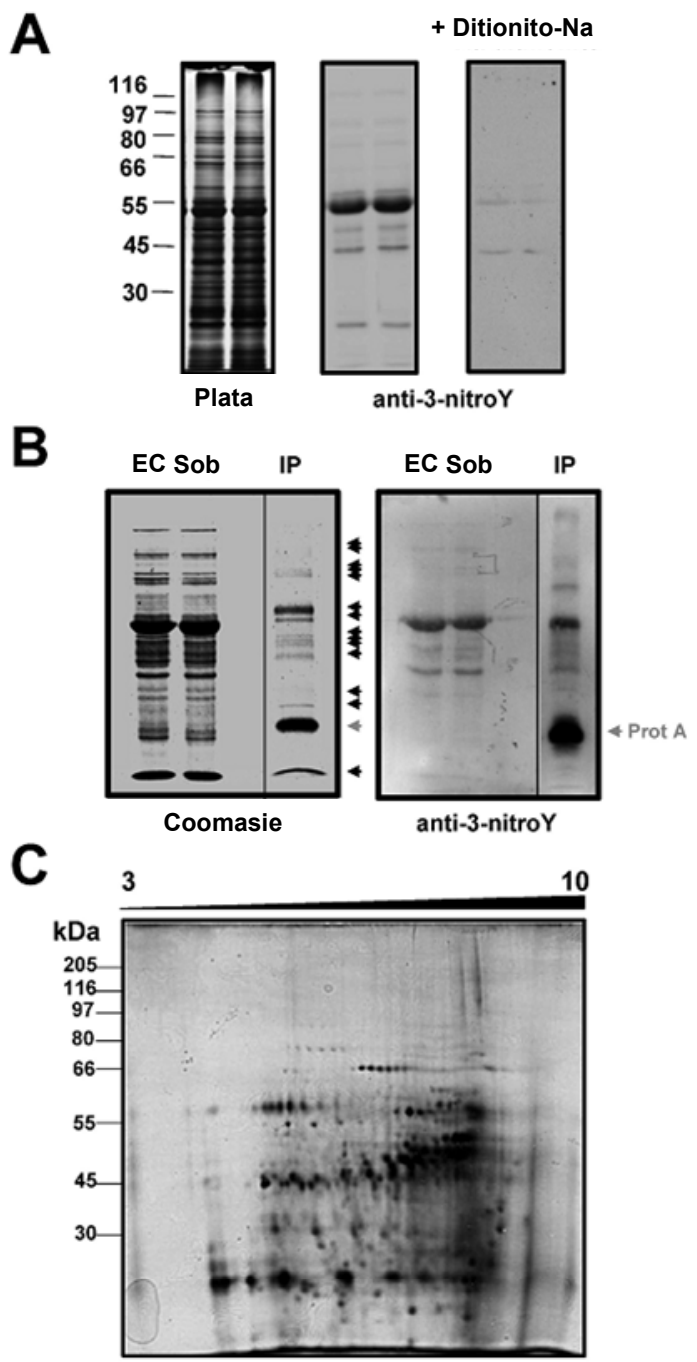

\section{Figura 34. Detección e immunoprecipitación} de proteínas nitradas en Arabidopsis.

A. Extractos crudos de proteínas (10 $\mu$ g por carril) se separaron en geles de 10\% SDS-PAGE. El panel de la izquierda muestra el gel teñido con plata junto con la posición del marcador de pesos moleculares. El panel central muestra el Western-blot con anticuerpos anti-3-nitroY, y el panel de la derecha un duplicado del western donde se trató la membrana con $100 \mathrm{mM}$ de ditionito sódico durante $30 \mathrm{~min}$ antes de la incubación con el anticuerpo anti-3nitroY. B. Inmunoprecipitación de proteínas nitradas. El extracto crudo (EC) de proteínas se inmunoprecipitó con anticuerpos anti-3-nitroY. El sobrenadante (Sob) y la correspondiente fracción immunoprecipitada (IP) se separaron en geles SDSPAGE monodimensionales por duplicado y fueron teñidos con Coomassie (izquierda) o transferidos a una membrana e incubados con anticuerpos anti-3nitroY (derecha). Las proteínas inmunoprecipitadas están marcadas con una flecha negra y la proteína A liberada tras la elución con una flecha gris. C. Gel $2 \mathrm{D}$, en el rango de $\mathrm{pH} 3-10$ en la primera dimensión y con $10 \%$ SDS-PAGE en segunda dimensión, donde se separaron $100 \mu \mathrm{g}$ de proteínas inmunoprecipitadas, y se tiñó con plata. 
Además, la especificidad de la reacción del anticuerpo con los residuos de 3-nitroY de dichas proteínas se comprobó mediante la reducción de las proteínas con ditionito sódico, que reduce los residuos de 3-nitroY a 3-aminoY, tal como se ha descrito previamente (Miyagi et al., 2002), y que conlleva a la ausencia de reacción del anticuerpo con las proteínas mencionadas anteriormente (Fig. 34A). Una vez validada la especificidad del anticuerpo, se utilizó, junto con proteína A-agarosa, para immunoprecipitar proteínas que contuvieran 3-nitroY en extractos crudos de plántulas de Arabidopsis. En la Figura 33B se muestra que un pequeño conjunto de proteínas presentes en los extractos crudos, menos de 20 bandas detectadas mediante la tinción con Coomassie, pudieron ser recuperadas en la fracción immunoprecipitada. Se comprobó también que estas proteínas reaccionaban en Western-blot con los anticuerpos anti-3-nitroY (Fig. 34B) observando un enriquecimiento moderado de proteínas nitradas en la fracción immunoprecipitada (Fig. 34B). Teniendo en cuenta la baja resolución de los geles monodimensionales y para intentar definir de forma más exacta el número y complejidad de las proteínas immunoprecipitadas, éstas se separaron mediante electroforesis bidimensional (2-DE) y se visualizaron mediante la tinción con plata, resultando en la separación de alrededor de 450 spots con puntos isoeléctricos (pI) que comprendían desde pI 3 hasta pI 10 (Fig. 34C).

Ya que la nitración de proteínas requiere de la formación del agente nitrante, peroxinitrito, y puesto que éste es derivado de la reacción del NO con el ión superóxido (Fig 35), comprobamos en primer lugar, que tal y como ha sido descrito, existe una producción simultánea de ión superóxido y NO en condiciones fisiológicas en ausencia de estrés (Foreman et al., 2003; Gapper y Dolan 2006; Valderrama et al., 2007; Sandalio et al., 2008; Tsukagoshi et al., 2010). Para ello, teñimos raíces de plántulas silvestres con Azul de Nitrotetrazolio (NBT), que produce un color azulado en presencia de ión superóxido, y con la fluoresceína específica de NO, DAF-FM DA.

\section{NBT}
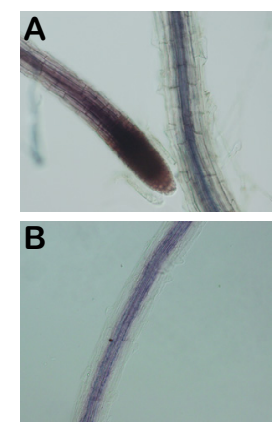
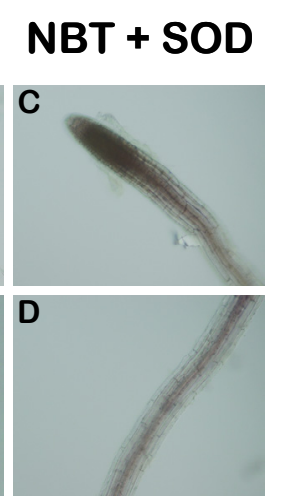
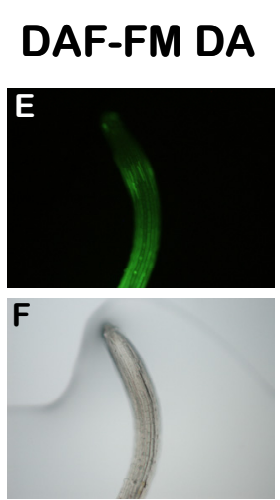

\section{DAF-FM DA}

+ CPTIO
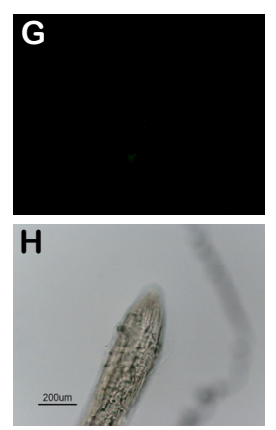

Figura 35. Detección de superóxido y NO en raíces de plántulas silvestres crecidas en condiciones estándar.

A,B. Se muestran diferentes zonas de raíces teñidas con NBT. C,D. Las raíces se trataron con $10 \mathrm{U} / \mathrm{mL}$ de superóxido dismutasa (SOD) antes de la tinción con NBT. Tinción de las raíces con DAF-FM DA en raíces pre-tratadas $(\mathrm{G}, \mathrm{H})$ o no (E,F) con cPTIO. Se muestran las raíces en fotos tomadas bajo iluminación UV (E,G) o en campo claro (F,H). 
Así, comprobamos que existe una producción de ión superóxido y de $\mathrm{NO}$ en condiciones basales que se puede revertir mediante la aplicación del enzima Superóxido Dismutasa (SOD) o del secuestrador cPTIO para el ión superóxido y el óxido nítrico, respectivamente (Fig. 35). Posteriormente, analizamos de que manera cambios en la producción de NO pueden alterar el patrón en la nitración de proteínas (Fig. 36). Ha sido descrito que la aplicación exógena de ácido salicílico (SA) activa la producción de NO en raíces de Arabidopsis (Zottini et al., 2007, Fig. 36A). Mediante la tinción fluorescente con la fluoresceína no permeable y específica de NO, DAF2, encontramos que el tratamiento con SA induce la síntesis de $\mathrm{NO}$ en plántulas completas de Arabidopsis y no solo en raíces (Fig. 36B). Además, la acumulación de NO se incrementó al menos hasta 24 horas tras el tratamiento con SA (Fig. 36B). La especificidad de la detección por el NO fue comprobada mediante la cuantificación de la fluorescencia tras añadir el secuestrador de NO cPTIO en presencia de SA, lo que provocó una clara bajada en la fluorescencia (Fig. 36A, B).

A

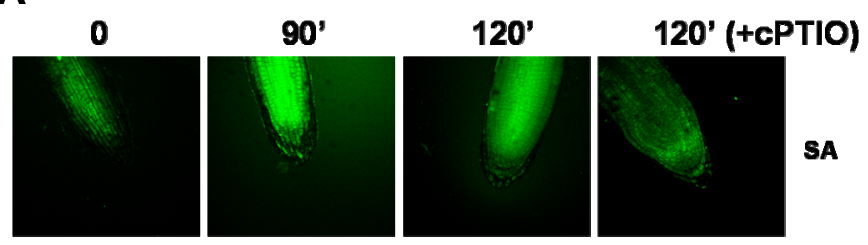

B

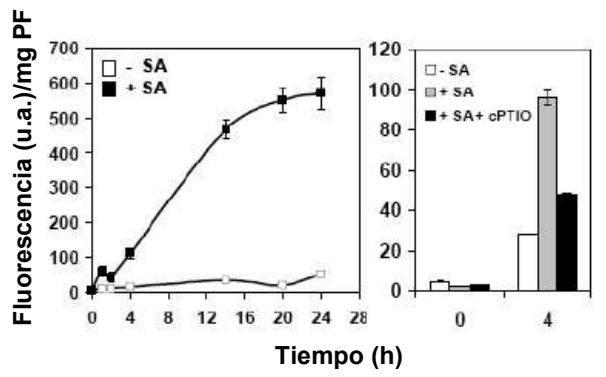

C

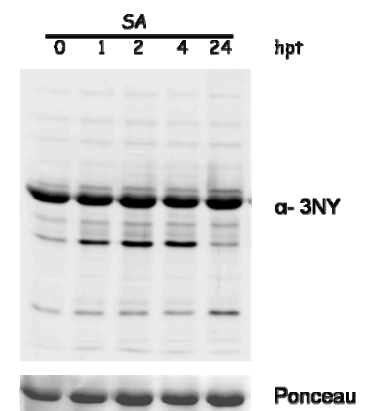

Figura 36. La producción de NO inducida por el SA se acompaña de un cambio en el patrón de proteínas nitradas.

A. Detección de la producción de NO, mediante la fluoresceína DAF-FM DA, en raíces de plántulas tratadas con $1 \mathrm{mM}$ SA por los tiempos indicados. B. Detección de la fluorescencia asociada a la producción de NO a diferentes horas tras el tratamiento con SA (+SA, izquierda) y 4 horas tras un tratamiento control (-SA), $1 \mathrm{mM} \mathrm{SA}(+\mathrm{SA})$ o $1 \mathrm{mM} \mathrm{SA}+250 \mu \mathrm{M}$ cPTIO (+SA+cPTIO) (derecha) mediante la fluoresceína no permeable DAF-2. La fluorescencia se midió por triplicado con ayuda de un fluorímetro. C. Western-blot con anticuerpos anti-3-nitro-Y $(\alpha-3 \mathrm{NY})$ a diferentes horas después del tratamiento (hpt) con $1 \mathrm{mM} \mathrm{SA}$. 
Mediante análisis por Western-blot encontramos un cambio en el patrón de las proteínas nitradas en respuesta a SA, entre dos y cuatro horas después de tratar con la hormona (Fig. 36C). Esto indica que el patrón de proteínas nitradas es dinámico y responde a estímulos que promueven la producción de NO, pudiendo tener un potencial papel señalizador, tal y como ocurre en modelos animales.

\section{Identificación de proteínas potencialmente nitradas}

Para poder identificar potenciales dianas de nitración in vivo en Arabidopsis, la fracción immunoprecipitada se analizó mediante espectrometría de masas (MS) siguiendo dos estrategias diferentes y complementarias. En primer lugar, se llevó a cabo un análisis tipo "shotgun", basado en la utilización de metodologías de identificación masiva de proteínas (Steen y Mann 2004). En este caso se utilizó la cromatografía líquida para separar los diferentes péptidos provenientes de la mezcla compleja de proteínas y la posterior identificación de los mismos mediante espectrometría de masas en tandem (LC-MS/MS) que, junto con un último paso de búsqueda bioinformática, permiten asignar los diferentes péptidos identificados a diferentes proteínas con un alto nivel de probabilidad (Steen y Mann, 2004). De esta forma, analizamos la fracción immunoprecipitada mediante los anticuerpos anti-3-nitroY y, una vez comparados los datos obtenidos por MS con la base de datos de SwissProt, especificando Arabidopsis como el organismo de estudio, se identificaron 127 proteínas con una puntuación estadísticamente significativa en el algoritmo desarrollado por MASCOT (score), mayor o igual a $35 \mathrm{y}$ al menos dos péptidos identificados por asignación (Tabla III). Entre las proteínas identificadas, el 35\% tienen homólogos previamente descritos como nitrados en organismos modelo diferentes de las plantas (Tabla S1), lo que sugiere que la aproximación es útil para la identificación de proteínas nitradas.

Tabla IV. Proteínas immunoprecipitadas con anticuerpos anti-3-nitro-Y e identificadas en plántulas de Arabidopsis thaliana mediante LC-MS/MS. Aquellas proteínas que han sido descritas previamente como nitradas en plantas han sido marcadas con * (Chaki et al. 2009b) o § (Cecconi et al. 2009). AGI, Iniciativa del Genoma de Arabidopsis, n.r., no redundantes.

\begin{tabular}{|l|l|l|l|l|l|}
\hline SwissProt & AGI & Descripción & $\begin{array}{l}\text { Score } \\
\text { Mascot }\end{array}$ & $\begin{array}{l}\text { Péptidos } \\
\text { identifica } \\
\text { dos (n.r.) }\end{array}$ & Mejores péptidos (Score de Ion ) \\
\hline ATPB_ARATH & AtCg00480 & $\begin{array}{l}\text { ATP sintasa, } \\
\text { subunidad beta }\end{array}$ & 1150 & 23 & $\begin{array}{l}\text { R.FVQAGSEVSALLGR.M (85) } \\
\text { K.IGLFGGAGVGK.T (80) }\end{array}$ \\
\hline METE_ARATH & At5g17920 & Metionina sintasa 1 & 1014 & 27 & $\begin{array}{l}\text { K.DEALFSANAAALASR.R (97) } \\
\text { K.MLAVLEQNILWVNPDCGLK.T(91) }\end{array}$ \\
\hline G3PB_ARATH & At1g42970 & $\begin{array}{l}\text { GAPDH B, } \\
\text { cloroplástica }\end{array}$ & 884 & 22 & $\begin{array}{l}\text { K.IVDNETISVDGK.L (85) } \\
\text { R.KDSPLEVVVLNDSGGVK.N (75) }\end{array}$ \\
\hline G3PA_ARATH & At3g26650 & $\begin{array}{l}\text { GAPDH A, } \\
\text { cloroplástica }\end{array}$ & 831 & 18 & $\begin{array}{l}\text { R.VPTPNVSVVDLVVQVSK.K (68) } \\
\text { K.KVIITAPGK.G (60) }\end{array}$ \\
\hline RCA_ARATH & At2g39730 & $\begin{array}{l}\text { § RuBisCo activasa, } \\
\text { cloroplástica }\end{array}$ & 761 & 20 & $\begin{array}{l}\text { R.GLAYDTSDDQQDITR.G (81) } \\
\text { R.VQLAETYLSQAALGDANADAIGR. } \\
\text { G (72) }\end{array}$ \\
\hline
\end{tabular}




\begin{tabular}{|c|c|c|c|c|c|}
\hline GOX1_ARATH & At3g14415 & Glicolato oxidasa1 & 670 & 16 & $\begin{array}{l}\text { R.AASAAGTIMTLSSWATSSVEEVAST } \\
\text { GPGIR.F (101) } \\
\text { K.DIQWLQTITNMPILVK.G (58) }\end{array}$ \\
\hline GOX2_ARATH & At3g14420 & Glicolato oxidasa2 & 651 & 16 & $\begin{array}{l}\text { R.AASAAGTIMTLSSWATSSVEEVAST } \\
\text { GPGIR.F (101) } \\
\text { R.IPVFLDGGVR.R (52) }\end{array}$ \\
\hline SAHH1_ARATH & At4g13940 & $\begin{array}{l}* \text { Adenosil } \\
\text { homocisteinasa } 1\end{array}$ & 581 & 18 & $\begin{array}{l}\text { K.VALLHLGK.L (55) } \\
\text { R.DSAAVFAWK.G (54) }\end{array}$ \\
\hline PGKH_ARATH & At1g56190 & $\begin{array}{l}\text { Fosfoglicerato } \\
\text { kinasa, cloroplástica }\end{array}$ & 542 & 14 & $\begin{array}{l}\text { K.LASLADLYVNDAFGTAHR.A (77) } \\
\text { K.FAAGTEAIANK.L (75) }\end{array}$ \\
\hline ATPA_ARATH & AtCg00120 & $\begin{array}{l}\text { § ATP sintasa } \\
\text { subunidad alfa }\end{array}$ & 504 & 12 & $\begin{array}{l}\text { R.EAYPGDVFYLHSR.L (64) } \\
\text { R.EQHTLIIYDDLSK.Q (62) }\end{array}$ \\
\hline EFTU_ARATH & At4g20360 & $\begin{array}{l}\text { Factor de elongación } \\
\text { Tu, cloroplástico }\end{array}$ & 491 & 13 & $\begin{array}{l}\text { K.KYDEIDAAPEER.A (72) } \\
\text { R.SYTVTGVEMFQK.I (54) }\end{array}$ \\
\hline G3PC_ARATH & At3g04120 & $\begin{array}{l}\text { GAPDH C, } \\
\text { citosólico }\end{array}$ & 479 & 13 & $\begin{array}{l}\text { R.VPTVDVSVVDLTVR.L (71) } \\
\text { K.KVVISAPSK.D (52) }\end{array}$ \\
\hline CAHC_ARATH & At3g01500 & $\begin{array}{l}\text { Anhidrasa carbónica } \\
1 \text {, cloroplástica }\end{array}$ & 475 & 13 & $\begin{array}{l}\text { K.YGGVGAAIEYAVLHLK.V (64) } \\
\text { R.EAVNVSLANLLTYPFVR.E (60) }\end{array}$ \\
\hline EF1A_ARATH & At1g07940 & $\begin{array}{l}\text { Factor de elongación } \\
1 \text {-alfa }\end{array}$ & 450 & 11 & $\begin{array}{l}\text { R.EHALLAFTLGVK.Q (103) } \\
\text { K.FHINIVVIGHVDSGK.S (82) }\end{array}$ \\
\hline ACT7_ARATH & At5g09810 & Actina-7 & 448 & 12 & $\begin{array}{l}\text { K.SEYDESGPSIVHR.K (75) } \\
\text { K.NYELPDGQVITIGAER.F (57) }\end{array}$ \\
\hline ACT2_ARATH & At3g18780 & Actina-2 & 430 & 12 & $\begin{array}{l}\text { K.NYELPDGQVITIGAER.F (57) } \\
\text { K.AGFAGDDAPR.A (52) }\end{array}$ \\
\hline KPPR_ARATH & At1g32060 & $\begin{array}{l}\text { Fosforibuloquinasa } \\
\text { cloroplástica }\end{array}$ & 418 & 13 & $\begin{array}{l}\text { R.LDELIYVESHLSNLSTK.F (55) } \\
\text { K.ILVIEGLHPMFDER.V (52) }\end{array}$ \\
\hline RUBB_ARATH & At1g55490 & $\begin{array}{l}\text { Subunidad larga, } \\
\text { RuBisCO }\end{array}$ & 389 & 13 & $\begin{array}{l}\text { R.GYISPYFVTDSEK.M (71) } \\
\text { K.YEDLMAAGIIDPTK.V (52) }\end{array}$ \\
\hline CAH2_ARATH & At5g14740 & $\begin{array}{l}\text { Anhidrasa carbónica } \\
2\end{array}$ & 379 & 11 & $\begin{array}{l}\text { R.EAVNVSLANLLTYPFVR.E (60) } \\
\text { K.VENIVVIGHSACGGIK.G (59) }\end{array}$ \\
\hline TBA6_ARATH & At4g14960 & $\begin{array}{l}\text { Tubulina, cadena } \\
\text { alfa- } 6\end{array}$ & 358 & 11 & $\begin{array}{l}\text { R.AVFVDLEPTVIDEVR.T (67) } \\
\text { R.LVSQVISSLTASLR.F (50) }\end{array}$ \\
\hline METK1_ARATH & Atlg02500 & $\begin{array}{l}\text { S-adenosil } \\
\text { metionina sintetasa } 1\end{array}$ & 334 & 11 & $\begin{array}{l}\text { R.FVIGGPHGDAGLTGR.K (73) } \\
\text { K.IIIDTYGGWGAHGGGAFSGK.D (64) }\end{array}$ \\
\hline RUBA_ARATH & At2g28000 & $\begin{array}{l}\text { Subunidad larga, } \\
\text { alfa, RuBisCO }\end{array}$ & 331 & 11 & $\begin{array}{l}\text { K.VVNDGVTIAR.A (60) } \\
\text { K.TNDSAGDGTTTASILAR.E (56) }\end{array}$ \\
\hline METK2_ARATH & At4g01850 & $\begin{array}{l}\text { S-adenosil } \\
\text { metionina sintetasa } 2\end{array}$ & 326 & 11 & $\begin{array}{l}\text { R.FVIGGPHGDAGLTGR.K (73) } \\
\text { K.IIIDTYGGWGAHGGGAFSGK.D (64) }\end{array}$ \\
\hline GLNA2_ARATH & At5g35630 & $\begin{array}{l}\text { § Glutamina sintasa, } \\
\text { cloroplástica/ } \\
\text { mitocondrial }\end{array}$ & 314 & 10 & $\begin{array}{l}\text { K.VSGEVPWFGIEQEYTLLQQNVK.W } \\
(76) \\
\text { K.HETASIDQFSWGVANR.G (42) }\end{array}$ \\
\hline SGAT_ARATH & At2g13360 & $\begin{array}{l}\text { Serina-glioxilato } \\
\text { aminotransferasa }\end{array}$ & 306 & 10 & $\begin{array}{l}\text { R.AALDLIFEEGLENIIAR.H (61) } \\
\text { K.VFFDWNDYLK.F (42) }\end{array}$ \\
\hline RBS1A_ARATH & At1g67090 & $\begin{array}{l}\text { Cadena pequeña } 1 \mathrm{~A} \\
\text { RuBisCO, } \\
\text { cloroplástica }\end{array}$ & 299 & 9 & $\begin{array}{l}\text { K.LPLFGCTDSAQVLK.E (71) } \\
\text { K.EVDYLIR.N (46) }\end{array}$ \\
\hline TBA3_ARATH & At5g19770 & $\begin{array}{l}\text { Tubulina cadena } \\
\text { alfa-3/alfa-5 }\end{array}$ & 284 & 8 & $\begin{array}{l}\text { R.AVFVDLEPTVIDEVR.T (67) } \\
\text { R.LISQIISSLTTSLR.F (65) }\end{array}$ \\
\hline PORB_ARATH & At4g27440 & $\begin{array}{l}\text { Protoclorofilida } \\
\text { reductasa B }\end{array}$ & 263 & 12 & $\begin{array}{l}\text { R.LLLDDLKK.S (53) } \\
\text { K.GYVSETESGKR.L (46) }\end{array}$ \\
\hline RBS1B_ARATH & At5g38430 & $\begin{array}{l}\text { Cadena pequeña 1B } \\
\text { RuBisCO, } \\
\text { cloroplástica }\end{array}$ & 254 & 7 & $\begin{array}{l}\text { K.LPLFGCTDSAQVLK.E (71) } \\
\text { K.EVDYLLR.N (46) }\end{array}$ \\
\hline ILV5_ARATH & At3g58610 & $\begin{array}{l}\text { Cetoácido } \\
\text { reductoisomerasa, } \\
\text { cloroplástica }\end{array}$ & 240 & 9 & $\begin{array}{l}\text { K.VSLAGYEEYIVR.G (44) } \\
\text { K.APVSLDFETSVFK.K (43) }\end{array}$ \\
\hline TBB4_ARATH & At5g44340 & $\begin{array}{l}\text { Tubulina cadena } \\
\text { beta- } 4\end{array}$ & 226 & 8 & $\begin{array}{l}\text { K.LAVNLIPFPR.L (54) } \\
\text { R.YLTASAVFR.G (35) }\end{array}$ \\
\hline HSP71_ARATH & At5g02500 & $\begin{array}{l}\text { * Proteína de choque } \\
\text { térmico } 1,70 \mathrm{kDa}\end{array}$ & 217 & 10 & $\begin{array}{l}\text { R.MVNHFVQEFK.R (40) } \\
\text { K.ATAGDTHLGGEDFDNR.M (35) }\end{array}$ \\
\hline F16P1_ARATH & At3g54050 & $\begin{array}{l}\text { Fructosa-1,6- } \\
\text { bisfosfatasa }\end{array}$ & 214 & 10 & $\begin{array}{l}\text { R.TLLYGGIYGYPR.D (58) } \\
\text { R.VLDIQPTEIHQR.V (42) }\end{array}$ \\
\hline TBB2_ARATH & At5g62690 & $\begin{array}{l}\text { Tubulina cadena } \\
\text { beta- } 2 / \text { beta- } 3\end{array}$ & 203 & 9 & $\begin{array}{l}\text { K.LAVNLIPFPR.L (54) } \\
\text { R.AVLMDLEPGTMDSLR.S (35) }\end{array}$ \\
\hline TBB1_ARATH & At1g75780 & $\begin{array}{l}\text { Tubulina cadena } \\
\text { beta- } 1\end{array}$ & 193 & 8 & $\begin{array}{l}\text { K.LAVNLIPFPR.L (54) } \\
\text { R.AVLMDLEPGTMDSIR.S (35) }\end{array}$ \\
\hline
\end{tabular}




\begin{tabular}{|c|c|c|c|c|c|}
\hline PGMP_ARATH & At5g51820 & $\begin{array}{l}\text { Fosfoglucomutasa, } \\
\text { cloroplástica }\end{array}$ & 173 & 9 & $\begin{array}{l}\text { K.SLPTKPIEGQK.T (30) } \\
\text { K.LPFFEVPTGWK.F (26) }\end{array}$ \\
\hline P2SAF_ARATH & At5g23120 & $\begin{array}{l}\text { Factor de } \\
\text { estabilidad/ensambla } \\
\text { je del Fotosistema II } \\
\text { HCF136 }\end{array}$ & 172 & 8 & $\begin{array}{l}\text { R.ADGGLWLLVR.G (40) } \\
\text { K.GTGITEEFEEVPVQSR.G (34) }\end{array}$ \\
\hline HSP73_ARATH & At3g09440 & $\begin{array}{l}\text { * Proteína de choque } \\
\text { térmico } 3,70 \mathrm{kDa}\end{array}$ & 172 & 7 & $\begin{array}{l}\text { R.MVNHFVQEFK.R (40) } \\
\text { K.ATAGDTHLGGEDFDNR.M (35) }\end{array}$ \\
\hline APX1_ARATH & At1g07890 & $\begin{array}{l}\text { L-ascorbato } \\
\text { peroxidasa } 1, \\
\text { citosólica }\end{array}$ & 161 & 5 & $\begin{array}{l}\text { K.EGLLQLVSDK.A (44) } \\
\text { K.QMGLSDKDIVALSGAHTLGR.C (35) }\end{array}$ \\
\hline MTDH_ARATH & At4g39330 & $\begin{array}{l}\text { Probable Manitol } \\
\text { deshidrogenasa }\end{array}$ & 139 & 5 & $\begin{array}{l}\text { K.NYGGYSENIVVDQR.F (47) } \\
\text { K.NYGGYSENIVVDQR.F (34) }\end{array}$ \\
\hline CD48A_ARATH & At3g09840 & $\begin{array}{l}\text { Proteína de control } \\
\text { de la división celular } \\
\text { de } 48 \mathrm{~A}\end{array}$ & 120 & 6 & $\begin{array}{l}\text { R.KGDLFLVR.G (29) } \\
\text { R.IVSQLLTLMDGLK.S (29) }\end{array}$ \\
\hline GME_ARATH & At5g28840 & $\begin{array}{l}\text { GDP-manosa 3,5- } \\
\text { epimerasa }\end{array}$ & 112 & 5 & $\begin{array}{l}\text { R.SFTFIDECVEGVLR.L (43) } \\
\text { K.KLPIHHIPGPEGVR.G (31) }\end{array}$ \\
\hline GBLP_ARATH & At1g18080 & $\begin{array}{l}\text { Proteína de unión a } \\
\text { Guanin nucleótido, } \\
\text { subunidad beta }\end{array}$ & 103 & 4 & $\begin{array}{l}\text { R.LWDLAAGVSTR.R (42) } \\
\text { K.DGVVLLWDLAEGK.K (27) }\end{array}$ \\
\hline CLPP_ARATH & AtCg00670 & $\begin{array}{l}\text { Clp proteasa ATP- } \\
\text { dependiente }\end{array}$ & 99 & 2 & $\begin{array}{l}\text { R.SPGEGDTSWVDIYNR.L (70) } \\
\text { R.TGKPIWVISEDMER.D (30) }\end{array}$ \\
\hline GCST_ARATH & At1g11860 & $\begin{array}{l}\text { Aminometiltransfera } \\
\text { sa, mitocondrial }\end{array}$ & 99 & 5 & $\begin{array}{l}\text { K.GGDVSWHIHDER.S (25) } \\
\text { R.AEGGFLGADVILQQLK.D (24) }\end{array}$ \\
\hline AAT5_ARATH & At4g31990 & $\begin{array}{l}\text { Aspartato } \\
\text { aminotransferasa, } \\
\text { cloroplástica }\end{array}$ & 98 & 5 & $\begin{array}{l}\text { K.ATAELLFGAGHPVIK.E (27) } \\
\text { R.VATIQGLSGTGSLR.L (24) }\end{array}$ \\
\hline ACA9_ARATH & At3g21180 & $\begin{array}{l}\text { ATPasa } 9 \text { de } \\
\text { transporte de } \mathrm{Ca}, \\
\text { membrana } \\
\text { plasmática }\end{array}$ & 98 & 7 & $\begin{array}{l}\text { R.VAIDSMAK.N (28) } \\
\text { R.QAALVLNASRR.F (21) }\end{array}$ \\
\hline RH56_ARATH & At5g11200 & $\begin{array}{l}\text { DEAD-box RNA } \\
\text { helicasa ATP- } \\
\text { dependiente } 56\end{array}$ & 97 & 5 & $\begin{array}{l}\text { K.LSEMEKNR.K (30) } \\
\text { K.VSVFYGGVNIK.I (25) }\end{array}$ \\
\hline ENO_ARATH & At2g36530 & Enolasa & 96 & 6 & $\begin{array}{l}\text { K.AGAVVSGIPLYK.H (30) } \\
\text { K.LAMQEFMILPVGAASFK.E (30) }\end{array}$ \\
\hline MRP7_ARATH & At3g13100 & $\begin{array}{l}\text { Proteína asociada a } \\
\text { la resistencia de } \\
\text { multidrogas } 7\end{array}$ & 86 & 7 & $\begin{array}{l}\text { R.YGPHLPMVLRGLTCTFR.G (20) } \\
\text { R.GIEAGWLK.K (17) }\end{array}$ \\
\hline AFB3_ARATH & Atlg12820 & $\begin{array}{l}\text { F-Box de } \\
\text { señalización de } \\
\text { auxinas } 3\end{array}$ & 84 & 6 & $\begin{array}{l}\text { R.LWILDSIGDK.G ( } 23) \\
\text { R.LMSCAPQLVDLGVGSYENEPDPESF } \\
\text { AK.L (17) }\end{array}$ \\
\hline PDX13_ARATH & At5g01410 & $\begin{array}{l}\text { Proteína de } \\
\text { biosíntesis de } \\
\text { piridoxal }\end{array}$ & 79 & 4 & $\begin{array}{l}\text { K.VGLAQMLR.G (43) } \\
\text { R.NMDDDEVFTFAK.K (14) }\end{array}$ \\
\hline PDX11_ARATH & At2g38230 & $\begin{array}{l}\text { Proteína de } \\
\text { biosíntesis de } \\
\text { piridoxal }\end{array}$ & 75 & 3 & $\begin{array}{l}\text { K.VGLAQMLR.G (43) } \\
\text { K.IAAPYDLVVQTK.E (20) }\end{array}$ \\
\hline EFTM_ARATH & At4g02930 & $\begin{array}{l}\text { Factor de elongación } \\
\text { Tu, mitocondrial }\end{array}$ & 75 & 2 & $\begin{array}{l}\text { R.GSALSALQGTNDEIGR.Q (49) } \\
\text { K.LMDAVDEYIPDPVR.V (26) }\end{array}$ \\
\hline MDR11_ARATH & At3g28860 & $\begin{array}{l}\text { Proteína de } \\
\text { resistencia a } \\
\text { multidrogas } 11 \\
\text { (glicoproteína-P } \\
\text { 19) }\end{array}$ & 73 & 6 & $\begin{array}{l}\text { K.SSVIAMIER.F (24) } \\
\text { R.AVLKNPTVLLLDEATSALDAESECV } \\
\text { LQEALERLMR.G (22) }\end{array}$ \\
\hline MDHP_ARATH & At3g47520 & $\begin{array}{l}\text { Malato } \\
\text { deshidrogenasa, } \\
\text { cloroplástica }\end{array}$ & 70 & 3 & $\begin{array}{l}\text { K.DVNVVVIPAGVPR.K (35) } \\
\text { K.LFGVTTLDVVR.A (22) }\end{array}$ \\
\hline SR54C_ARATH & At5g03940 & $\begin{array}{l}\text { Partícula de } \\
\text { reconocimiento de } \\
\text { señal de } 54 \mathrm{kDa}, \\
\text { cloroplástica }\end{array}$ & 70 & 5 & $\begin{array}{l}\text { R.GVKPDQQLVK.I (16) } \\
\text { R.QEDAEDLQKK.I (16) }\end{array}$ \\
\hline MDHG1_ARATH & At5g09660 & $\begin{array}{l}\text { Malato } \\
\text { deshidrogenasa, }\end{array}$ & 70 & 3 & $\begin{array}{l}\text { R.TGAEEVYQLGPLNEYER.I (31) } \\
\text { K.LLGVTTLDVAR.A (30) }\end{array}$ \\
\hline
\end{tabular}




\begin{tabular}{|c|c|c|c|c|c|}
\hline & & glioxisomal & & & \\
\hline TAF1B_ARATH & At3g19040 & $\begin{array}{l}\text { Subunidad 1-B del } \\
\text { factor de iniciación } \\
\text { de la transcripción } \\
\text { TFIID }\end{array}$ & 69 & 7 & $\begin{array}{l}\text { R.ENLKQLNSDARGR.L (20) } \\
\text { K.EIGTPICQMKKILK.E (17) }\end{array}$ \\
\hline TYW23_ARATH & At4g04670 & $\begin{array}{l}\text { Proteína de síntesis } \\
\text { de tRNA de } \\
\text { wibutosina }\end{array}$ & 69 & 5 & $\begin{array}{l}\text { R.ADPLNILNDVWR.L (24) } \\
\text { K.RVIIAIRCSIR.M (15) }\end{array}$ \\
\hline CATA3_ARATH & At1g20620 & Catalasa-3 & 69 & 3 & $\begin{array}{l}\text { R.LGPNYLQLPVNAPK.C (32) } \\
\text { K.GFFEVTHDISNLTCADFLR.A (28) }\end{array}$ \\
\hline KASC1_ARATH & At5g46290 & $\begin{array}{l}\text { 3-oxoacil-[proteína } \\
\text { portadora de acilo] } \\
\text { sintasa I, } \\
\text { cloroplástica }\end{array}$ & 68 & 3 & $\begin{array}{l}\text { K.LLSGESGISLIDR.F (53) } \\
\text { R.ADGLGVSSCIER.C (9) }\end{array}$ \\
\hline ATPG1_ARATH & At4g04640 & $\begin{array}{l}\text { Cadena } 1 \text { de la ATP } \\
\text { sintasa gamma, } \\
\text { cloroplástica }\end{array}$ & 68 & 2 & $\begin{array}{l}\text { R.ALQESLASELAAR.M (52) } \\
\text { R.ASSVSPLQASLRELR.D (16) }\end{array}$ \\
\hline GRP7_ARATH & At2g21660 & $\begin{array}{l}\text { Proteína de unión a } \\
\text { RNA rica en glicina } \\
7\end{array}$ & 66 & 1 & R.ALETAFAQYGDVIDSK.I (66) \\
\hline FDH_ARATH & At5g14780 & $\begin{array}{l}\text { Formato } \\
\text { deshidrogenasa, } \\
\text { mitocondrial }\end{array}$ & 66 & 5 & $\begin{array}{l}\text { R.QAVVDAVESGHIGGYSGDVWDPQ } \\
\text { PAPK.D (18) } \\
\text { R.LQMAPELEK.E (17) }\end{array}$ \\
\hline HSP83_ARATH & At5g56010 & $\begin{array}{l}* \text { Proteína de choque } \\
\text { término } 81-3\end{array}$ & 62 & 5 & $\begin{array}{l}\text { K.GIEVLYMVDAIDEYAIGQLK.E (21) } \\
\text { K.EGQNDIFYITGESK.K (16) }\end{array}$ \\
\hline TGA2_ARATH & At5g06950 & $\begin{array}{l}\text { Factor de } \\
\text { transcripción TGA2 }\end{array}$ & 61 & 4 & $\begin{array}{l}\text { K.LTQLEQELQR.A (19) } \\
\text { R.LQTLQQMIR.V (15) }\end{array}$ \\
\hline TCPA_ARATH & At3g20050 & $\begin{array}{l}\text { Subunidad alfa de la } \\
\text { proteína } 1 \text { del } \\
\text { complejo T }\end{array}$ & 61 & 6 & $\begin{array}{l}\text { R.NKIHPTSIISGYR.L (19) } \\
\text { R.GANDYMLDEMER.A (15) }\end{array}$ \\
\hline CAPP3_ARATH & At3g14940 & $\begin{array}{l}\text { Fosfoenolpiruva } \\
\text { to carboxilasa } 3\end{array}$ & 60 & 4 & $\begin{array}{l}\text { K.LLVSEDLWAFGEKLR.A (22) } \\
\text { K.RLVSDLGK.S (15) }\end{array}$ \\
\hline WRK19_ARATH & At4g12020 & $\begin{array}{l}\text { Factor de } \\
\text { transcripción } \\
\text { WRKY 19 } \\
\end{array}$ & 60 & 6 & $\begin{array}{l}\text { K.CTYLGCPSKRK.V (19) } \\
\text { K.LCQVEGCQKGAR.D (16) }\end{array}$ \\
\hline THI4_ARATH & At5g54770 & $\begin{array}{l}\text { Enzima de } \\
\text { biosíntesis de tiazol, } \\
\text { cloroplástica }\end{array}$ & 59 & 2 & $\begin{array}{l}\text { K.HAALFTSTIMSK.L (33) } \\
\text { K.ALDMNTAEDAIVR.L (26) }\end{array}$ \\
\hline OMT1_ARATH & At5g54160 & $\begin{array}{l}\text { Quercetina 3-O- } \\
\text { metiltransferasa } 1\end{array}$ & 59 & 2 & $\begin{array}{l}\text { K.NPEAPVMLDR.I (34) } \\
\text { K.VLMESWYHLK.D (25) }\end{array}$ \\
\hline IF5A2_ARATH & At1g26630 & $\begin{array}{l}\text { Factor de iniciación } \\
\text { de la traducción de } \\
\text { eucariotas (eIF-5A) }\end{array}$ & 59 & 2 & $\begin{array}{l}\text { K.LPTDDGLTAQMR.L (33) } \\
\text { K.CHFVAIDIFTAK.K (26) }\end{array}$ \\
\hline PKL_ARATH & At2g25170 & $\begin{array}{l}\text { Factor de } \\
\text { remodelación de la } \\
\text { cromatina PICKLE }\end{array}$ & 58 & 6 & $\begin{array}{l}\text { K.GLLHPYQLEGLNFLR.F (19) } \\
\text { K.AYKSNHRLK.T (14) }\end{array}$ \\
\hline Y1934_ARATH & At1g09340 & $\begin{array}{l}\text { Proteína } \\
\text { cloroplástica no } \\
\text { caracterizada }\end{array}$ & 57 & 3 & $\begin{array}{l}\text { K.SSLSAEGFDVVYDINGR.E (26) } \\
\text { R.FIGLFLSR.I (16) }\end{array}$ \\
\hline VIN3_ARATH & At5g57380 & $\begin{array}{l}\text { Proteína de } \\
\text { insensibilización a la } \\
\text { vernalización } 3 \\
\end{array}$ & 56 & 5 & $\begin{array}{l}\text { R.GIVNRLSSGVHVQKLCSQAMEALD } \\
\text { K.V (27) } \\
\text { R.NEIMKIICAEMGKER.K (14) }\end{array}$ \\
\hline PME4_ARATH & At2g47030 & $\begin{array}{l}\text { Pectinesterasa-4 } \\
\text { (proteína 1 tipo } \\
\text { VANGUARD1) } \\
\end{array}$ & 54 & 6 & $\begin{array}{l}\text { K.AVQGICQSTSDKASCVK.T (16) } \\
\text { K.NTAGPMGHQAAAIRVNGDRAVIFN } \\
\text { CR.F (12) }\end{array}$ \\
\hline APT1_ARATH & At1g27450 & $\begin{array}{l}\text { Adenina } \\
\text { fosforibosiltrans } \\
\text { ferasa } 1 \text { (APRT 1) }\end{array}$ & 54 & 3 & $\begin{array}{l}\text { R.AIIIDDLIATGGTLAAAIR.L (35) } \\
\text { K.DTIALFVDR.Y (15) }\end{array}$ \\
\hline DRL19_ARATH & At1g63350 & $\begin{array}{l}\text { Putativa proteína de } \\
\text { resistencia } \\
\text { At1g63350 } \\
\end{array}$ & 54 & 4 & $\begin{array}{l}\text { R.NAELQRLCLCGFCSKSLTTSYR.Y } \\
(17) \\
\text { K.MCLLYCALFPEDAK.I (16) } \\
\end{array}$ \\
\hline FABG_ARATH & At1g24360 & $\begin{array}{l}\text { 3-oxoacil-[proteína } \\
\text { portadora de acilo] } \\
\text { reductasa, } \\
\text { cloroplástica }\end{array}$ & 54 & 3 & $\begin{array}{l}\text { K.WGTIDVVVNNAGITR.D (25) } \\
\text { K.ILGTIPLGR.Y (19) }\end{array}$ \\
\hline BSL1_ARATH & At4g03080 & Ser/Thr-protein & 53 & 4 & K.IICMHGGIGR.S (16) \\
\hline
\end{tabular}




\begin{tabular}{|c|c|c|c|c|c|}
\hline & & fosfatasa BSL1 & & & R.HGAASVGIRIYVHGGLR.G (16) \\
\hline PER9_ARATH & At1g44970 & Peroxidasa 9 & 52 & 3 & $\begin{array}{l}\text { K.AYAEDERLFFQQFAK.S (26) } \\
\text { K.EPRMAASLLR.L (13) }\end{array}$ \\
\hline UPL1_ARATH & At1g55860 & $\begin{array}{l}\text { E3 ubiquitin-protein } \\
\text { ligase UPL1 }\end{array}$ & 52 & 5 & $\begin{array}{l}\text { K.LLSDIVLMYSHGTSVILR.R (20) } \\
\text { R.LIDFDNKKAYFR.S (16) }\end{array}$ \\
\hline HDA5_ARATH & At5g61060 & $\begin{array}{l}\text { Histona deacetilasa } \\
5\end{array}$ & 51 & 3 & $\begin{array}{l}\text { R.KVGLIYDETMCK.H (24) } \\
\text { K.LQLAGVSQR.C (18) }\end{array}$ \\
\hline HAC12_ARATH & At1g16710 & $\begin{array}{l}\text { HAC12, Histona } \\
\text { acetiltransferasa }\end{array}$ & 51 & 5 & $\begin{array}{l}\text { K.LTTHPSLADQNAQNK.E (14) } \\
\text { K.ASGQSDFSGNASK.D (13) }\end{array}$ \\
\hline MRP14_ARATH & At3g59140 & $\begin{array}{l}\text { Proteína asociada a } \\
\text { la resistencia a } \\
\text { multidrogas } 14\end{array}$ & 50 & 7 & $\begin{array}{l}\text { R.IATFLEAPELQGGERRR.K (16) } \\
\text { R.VVAVENPTKPVK.E (11) }\end{array}$ \\
\hline ASHH2_ARATH & At1g77300 & $\begin{array}{l}\text { Histona-lisina N- } \\
\text { metiltransferasa } \\
\text { ASHH2 }\end{array}$ & 50 & 6 & $\begin{array}{l}\text { K.ILPRPRPR.M (13) } \\
\text { K.SPSENGSHLIPNAKKAK.H (13) }\end{array}$ \\
\hline ATM_ARATH & At3g48190 & $\begin{array}{l}\text { Ser/Thr-proteína } \\
\text { quinasa ATM } \\
\text { (PI3Kc_related) }\end{array}$ & 47 & 8 & $\begin{array}{l}\text { R.RVLLQILGCEKCTMQHLLQSASLLR } \\
\text {.K (14) } \\
\text { K.QIPMAQLHENEGRK.S (11) }\end{array}$ \\
\hline FBX10_ARATH & At1g51290 & Putativa F-box 10 & 47 & 4 & $\begin{array}{l}\text { R.LVICCYDETQQVYIYIVRR.N (16) } \\
\text { K.YVIGYDNKK.R (14) }\end{array}$ \\
\hline PSBP1_ARATH & At1g06680 & $\begin{array}{l}\text { Proteína } \\
\text { intensificadora de la } \\
\text { evolución de } \\
\text { oxígeno 2-1, } \\
\text { cloroplástica }\end{array}$ & 45 & 3 & $\begin{array}{l}\text { K.TNTDFLPYNGDGFK.V (25) } \\
\text { K.EIEYPGQVLR.F (12) }\end{array}$ \\
\hline CHLD_ARATH & At4g18480 & $\begin{array}{l}\text { Magnesio-quelatasa } \\
\text { subunidad D, } \\
\text { cloroplástica }\end{array}$ & 45 & 3 & $\begin{array}{l}\text { K.IYKAGMSLLVIDTENK.F (26) } \\
\text { R.VAAVGIATQFQERCNEVFR.M (22) }\end{array}$ \\
\hline FBK38_ARATH & At2g29800 & $\begin{array}{l}\text { Putativa F- } \\
\text { box/Kelch }\end{array}$ & 44 & 3 & $\begin{array}{l}\text { K.MANFGGKLVILGCYR.S (20) } \\
\text { R.HLRNMKR.D (16) }\end{array}$ \\
\hline GLYM_ARATH & At4g37930 & $\begin{array}{l}\text { Serina } \\
\text { hidroximetiltrans } \\
\text { ferasa, mitocondrial }\end{array}$ & 44 & 4 & $\begin{array}{l}\text { R.GFVEEDFAK.V (22) } \\
\text { K.VLEAVHIASNK.N (11) }\end{array}$ \\
\hline SCP37_ARATH & At3g52010 & $\begin{array}{l}\text { Serina } \\
\text { carboxipeptidasa } 37\end{array}$ & 44 & 3 & $\begin{array}{l}\text { K.AIHANTTK.L (19) } \\
\text { K.KLPGQPSGVSFR.Q (18) }\end{array}$ \\
\hline COL14_ARATH & At2g33500 & $\begin{array}{l}\text { Proteína tipo } \\
\text { Constans } 14\end{array}$ & 44 & 3 & $\begin{array}{l}\text { K.LCLPCDQHVHSANLLSR.K (20) } \\
\text { K.SNNIPAAIHSHK.S (14) }\end{array}$ \\
\hline SYV_ARATH & At1g14610 & Valil-tRNA sintetasa & 43 & 7 & $\begin{array}{l}\text { K.SDLFKADAK.S (16) } \\
\text { K.INLDILRVVGYR.Q (13) }\end{array}$ \\
\hline DRP1D_ARATH & At2g44590 & $\begin{array}{l}\text { Proteína relacionada } \\
\text { con la dinamina- 1D }\end{array}$ & 43 & 3 & $\begin{array}{l}\text { R.MQCAKRLELYK.K (22) } \\
\text { R.MGSEYLAK.L (14) }\end{array}$ \\
\hline VATB_ARATH & At1g76030 & $\begin{array}{l}\text { ATP sintasa } \\
\text { subunidad B, } \\
\text { vacuolar }\end{array}$ & 43 & 3 & $\begin{array}{l}\text { R.NIFQSLDLAWTLLR.I (16) } \\
\text { R.KFVMQGAYDTR.N (15) }\end{array}$ \\
\hline SIZ1_ARATH & At5g60410 & $\begin{array}{l}\text { Proteína E3 SUMO- } \\
\text { ligasa SIZ1 }\end{array}$ & 42 & 5 & $\begin{array}{l}\text { K.WQCPICLK.N (15) } \\
\text { R.HRSLNKICIILCAGK.N (12) }\end{array}$ \\
\hline HAC2_ARATH & At1g67220 & $\begin{array}{l}\text { HAC2, Histona } \\
\text { acetiltransferasa }\end{array}$ & 42 & 4 & $\begin{array}{l}\text { R.ACTGCYTKNRTLR.H (16) } \\
\text { K.LGTVVDIIEPMKCDER.S (11) }\end{array}$ \\
\hline TMK1_ARATH & At1g66150 & $\begin{array}{l}\text { Putativo receptor } \\
\text { tipo quinasa TMK1 }\end{array}$ & 42 & 4 & $\begin{array}{l}\text { K.GNDPCTNWIGIACSNGNITVISLEK. } \\
\text { M (18) } \\
\text { K.VVNLTNNHLQGPVPVFK.S (12) }\end{array}$ \\
\hline SYM_ARATH & At4g13780 & $\begin{array}{l}\text { Probable metionil- } \\
\text { tRNA sintasa }\end{array}$ & 42 & 3 & $\begin{array}{l}\text { R.LVEGSCPFEGCNYDSAR.G (26) } \\
\text { K.CKVCQNTPR.I (12) }\end{array}$ \\
\hline WEE1_ARATH & At1g02970 & $\begin{array}{l}\text { Proteína quinasa } \\
\text { tipo-Wee1 }\end{array}$ & 41 & 3 & $\begin{array}{l}\text { R.AMPPPCLK.N (19) } \\
\text { K.LPLLPGHSLQLQQLLK.T (15) }\end{array}$ \\
\hline ARR12_ARATH & At2g25180 & $\begin{array}{l}\text { Regulador de la } \\
\text { respuesta de dos } \\
\text { componentes }\end{array}$ & 41 & 5 & $\begin{array}{l}\text {-.MTVEQNLEALDQFPVGMR.V (17) } \\
\text { R.HCQYHVTTTNQAQK.A (9) }\end{array}$ \\
\hline CESA4_ARATH & At5g44030 & $\begin{array}{l}\text { Subunidad catalítica } \\
4 \text { de la Celulosa } \\
\text { sintasa A }\end{array}$ & 41 & 4 & $\begin{array}{l}\text { K.KAGAMNAMVR.V (22) } \\
\text { K.SSLMSQKNFEKR.F (12) }\end{array}$ \\
\hline AUR2_ARATH & At2g25880 & $\begin{array}{l}\text { Ser/Thr-proteína } \\
\text { quinasa Aurora-2 }\end{array}$ & 41 & 3 & $\begin{array}{l}\text { R.LYGYFYDQKRVYLILEYAVR.G (18) } \\
\text { M.LYQAASEAAQK.R (14) }\end{array}$ \\
\hline Y1838_ARATH & At1g18380 & $\begin{array}{l}\text { Proteína no } \\
\text { caracterizada }\end{array}$ & 41 & 3 & $\begin{array}{l}\text { R.YIMEDKACR.R (32) } \\
\text { R.SSDSDEGCMKYAEIPMLR.S (8) }\end{array}$ \\
\hline
\end{tabular}




\begin{tabular}{|c|c|c|c|c|c|}
\hline & & At1g18380 & & & \\
\hline 2AAA_ARATH & At1g25490 & $\begin{array}{l}\text { Ser/Thr-proteína } \\
\text { fosfatasa } 2 \mathrm{~A} \\
\text { subunidad } \\
\text { reguladora A alfa }\end{array}$ & 41 & 4 & $\begin{array}{l}\text { R.LAGGEWFAAR.V (17) } \\
\text { R.RAAASNLGK.F (11) }\end{array}$ \\
\hline FBK84_ARATH & At4g19865 & $\begin{array}{l}\text { Proteína F-box/kelch } \\
\text { At4g19865 }\end{array}$ & 40 & 3 & $\begin{array}{l}\text { K.IEFGNVNEMCAYDTKLCK.W (20) } \\
\text { K.IYVMGGCQGLKDEPWAEVFNTK.T } \\
(10)\end{array}$ \\
\hline MSH3_ARATH & At4g25540 & $\begin{array}{l}\text { Proteína de } \\
\text { reparación de DNA } \\
\text { MSH3 }\end{array}$ & 40 & 4 & $\begin{array}{l}\text { R.LVNAGYKIGVVK.Q (17) } \\
\text { R.LVNAGYK.I (13) }\end{array}$ \\
\hline DCDA1_ARATH & At3g14390 & $\begin{array}{l}\text { Diaminopimelato } \\
\text { descarboxilasa } 1 \text {, } \\
\text { cloroplástica }\end{array}$ & 39 & 1 & R.DAAVLMIEYIDEIR.R (39) \\
\hline GL25_ARATH & At5g26700 & $\begin{array}{l}\text { Probable proteína } \\
\text { tipo germina, } \\
\text { subfamilia } 2-5\end{array}$ & 39 & 3 & $\begin{array}{l}\text { R.IDYAPNGLNPPHVHPR.A (17) } \\
\text { K.LPGLNTLGLSMSR.I (14) }\end{array}$ \\
\hline CYSK1_ARATH & At4g14880 & $\begin{array}{l}\text { Cisteína sintasa } \\
\text { (OAS-TL A) }\end{array}$ & 39 & 3 & $\begin{array}{l}\text { K.IDGFVSGIGTGGTITGAGK.Y (21) } \\
\text { R.IGFSMISDAEK.K (15) }\end{array}$ \\
\hline MRP13_ARATH & At1g30410 & $\begin{array}{l}\text { Proteína de } \\
\text { resistencia a } \\
\text { multidrogas } 13\end{array}$ & 39 & 4 & $\begin{array}{l}\text { R.KKYYNCVLGLLACYCVVEPVLR.L } \\
\text { (22) } \\
\text { R.SVLIKQEER.E (14) }\end{array}$ \\
\hline ERG11_ARATH & At5g24150 & $\begin{array}{l}\text { Escualeno } \\
\text { monooxigenasa } 1,1\end{array}$ & 39 & 3 & $\begin{array}{l}\text { R.RLLQPLSNLGNAQK.I (18) } \\
\text { R.LFGLAMKMLVPHLK.A (13) }\end{array}$ \\
\hline DPOLA_ARATH & At5g67100 & $\begin{array}{l}\text { Subunidad catalítica } \\
\text { de la DNA } \\
\text { polimerasa alfa }\end{array}$ & 38 & 4 & $\begin{array}{l}\text { K.NGCNVLSIENSERALLNRLFLELNK. } \\
\text { L (14) } \\
\text { R.KRSGILSHFTVVR.N (13) }\end{array}$ \\
\hline CWP17_ARATH & At2g06850 & $\begin{array}{l}\text { Proteína de pared } \\
\text { celular de } 23 \mathrm{kDa}\end{array}$ & 38 & 3 & $\begin{array}{l}\text {-.IPCRKAIDVPFGTR.Y (19) } \\
\text { R.KAIDVPFGPR.Y (13) }\end{array}$ \\
\hline MOCOS_ARATH & At1g16540 & $\begin{array}{l}\text { Sulfurasa del } \\
\text { cofactor de } \\
\text { Molibdeno (ABA3) } \\
\end{array}$ & 38 & 7 & $\begin{array}{l}\text { K.LLKSLTPSAIWMHTTSLSIYVK.K } \\
(12) \\
\text { R.YEIDEKR.Q (10) }\end{array}$ \\
\hline ALA11_ARATH & At1g13210 & $\begin{array}{l}\text { ATPasa } \\
\text { transportadora de } \\
\text { fosfolípidos } 11\end{array}$ & 38 & 5 & $\begin{array}{l}\text { K.SLTYALEDDFKK.K (18) } \\
\text { R.SMAMRSNGSSLVGDDLDVVVDQS } \\
\text { GPK.I (10) }\end{array}$ \\
\hline TAP1_ARATH & At1g70610 & $\begin{array}{l}\text { Proteína tipo } \\
\text { transportador de } \\
\text { péptidos antigénicos } \\
\text { 1, cloroplástica }\end{array}$ & 38 & 3 & $\begin{array}{l}\text { R.GCFFGIANMILVKRMR.E (16) } \\
\text { R.QRIGYVGQEPK.L (12) }\end{array}$ \\
\hline AGO1_ARATH & At1g48410 & Argonauta & 37 & 2 & $\begin{array}{l}\text { R.INLLDEEVGAGGQR.R (36) } \\
\text { R.GYGQPPQQQQQYGGPQEYQGRGR. } \\
\text { G (4) }\end{array}$ \\
\hline FBK19_ARATH & At1g32430 & $\begin{array}{l}\text { Putativa proteína F- } \\
\text { box/Kelch } \\
\text { At1g32430 }\end{array}$ & 37 & 2 & $\begin{array}{l}\text { K.VEVRELTLNNPGLK.A (22) } \\
\text { R.CIKLEVNEPSLDFLGIGYDNNK.R } \\
\text { (14) }\end{array}$ \\
\hline LUMI_ARATH & At4g02560 & $\begin{array}{l}\text { LUMINIDEPENDE } \\
\text { NS }\end{array}$ & 37 & 2 & $\begin{array}{l}\text { K.KHMLGSNPSYNK.E (21) } \\
\text { K.HDSSTHPYWNQNK.R (18) }\end{array}$ \\
\hline CAPP1_ARATH & At1g53310 & $\begin{array}{l}\text { Fosfoenolpiruvato } \\
\text { carboxilasa } 1\end{array}$ & 36 & 2 & $\begin{array}{l}\text { K.LEELGSVLTSLDPGDSIVIAK.A (23) } \\
\text { K.GIAAGLQNTG.- (14) }\end{array}$ \\
\hline WBC16_ARATH & At3g55090 & $\begin{array}{l}\text { Probable proteína } \\
\text { homóloga al } \\
\text { complejo white- } \\
\text { brown } 16\end{array}$ & 36 & 2 & $\begin{array}{l}\text { K.TIIGDEGHR.G (29) } \\
\text { R.ILFYLCLLLGSKNK.R (8) }\end{array}$ \\
\hline CNGC4_ARATH & At5g54250 & $\begin{array}{l}\text { Canal iónico } \\
\text { activado por } \\
\text { nucleótidos cíclicos } \\
4\end{array}$ & 36 & 3 & $\begin{array}{l}\text { R.IGLTCGGR.R (36) } \\
\text { R.GVDECEMVQNLPEGLR.R (5) }\end{array}$ \\
\hline U496I_ARATH & At2g18630 & $\begin{array}{l}\text { Proteína UPF0496 } \\
\text { At2g18630 }\end{array}$ & 36 & 2 & $\begin{array}{l}\text { K.INSEYTEHLSSYER.A (21) } \\
\text { K.YEKVVRGQK.E (13) }\end{array}$ \\
\hline ARFM_ARATH & At1g34170 & $\begin{array}{l}\text { Factor de respuesta a } \\
\text { Auxinas } 13\end{array}$ & 36 & 2 & $\begin{array}{l}\text { K.FVDAMNNNYIVGSR.F (20) } \\
\text { K.FVDAMNNNYIVGSRFR.M (16) }\end{array}$ \\
\hline CYSKM_ARATH & At3g59760 & $\begin{array}{l}\text { Cisteína sintasa, } \\
\text { mitochondrial } \\
\text { (OAS-TL C) }\end{array}$ & 35 & 3 & $\begin{array}{l}\text { K.IQGIGAGFIPK.N (15) } \\
\text { R.IGYSMVTDAEQKGFISPGK.S (15) }\end{array}$ \\
\hline
\end{tabular}


Para validar nuestra identificación proteómica, llevamos a cabo la detección de varias de las proteínas identificadas mediante anticuerpos específicos en las muestras immunoprecipitadas. Para ello seleccionamos algunas proteínas identificadas con score MASCOT mayor de 200, como la enzima gliceraldehido-3-fosfato deshidrogenasa (GAPDH), anhidrasa carbónica (CA) o fructosa1,6-bifosfatasa (FBPasa) y otras con un score medio como la proteína de unión a RNA rica en glicina 7 (GRP7, score 66), el factor de remodelación de cromatina de tipo CHD3, PICKLE (PKL, score 58), y también la proteína O-acetilserina-tiol-liasa A1 (OAS-TL A1) que se identificó con uno de los scores más bajos (35) en este análisis. Todos los anticuerpos reaccionaron con proteínas en las muestras immunoprecipitadas con anti-3-nitroY (Fig. 37) validando la identificación proteómica. En la Figura 37 se puede observar que para algunas proteínas como GAPDH o PKL que no muestran señal en el sobrenadante de la inmunoprecipitación, la mayoría de la proteína está asociada con la fracción inmunoprecipitada. Al contrario, la inmunoprecipitación es mucho menos eficiente para proteínas como FBPasa o CA, las cuales muestran una cantidad de proteína similar en el sobrenadante y en el extracto crudo, sugiriendo que las formas nitradas correspondientes no deben ser abundantes en la población total de los extractos crudos. La mayoría de proteínas analizadas presentaron un

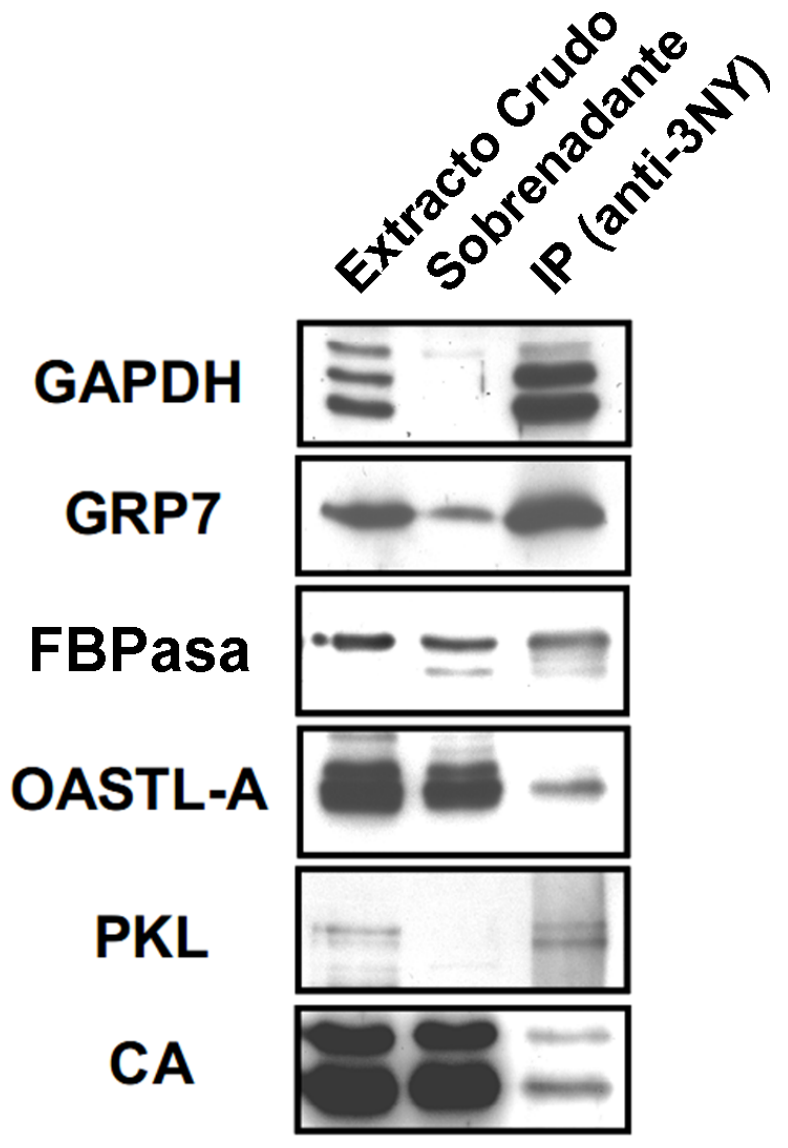

Figura 37. Validación de la identificación proteómica.

Los extractos crudos de proteínas fueron inmunoprecipitados con anticuerpos anti-3-nitroY (anti-3NY). El extracto crudo, el sobrenadante y la fracción inmunoprecipitada se separaron, se transfirieron a membrana y se incubaron con anticuerpos contra las proteínas gliceraldehido-3fosfato deshidrogenasa (GAPDH), proteína rica en glicina 7 (GRP7), fructosa bifosfatasa (FBPasa), Oacetilserina (tiol) liasa A1 (OASTL-A), Pickle (PKL) y anihidrasa carbónica (CA). Los carriles correspondientes al extracto crudo y al sobrenadante están cargados con un $1 \%$ de la proteína total utilizada para la inmunoprecipitación. 
patrón complejo de bandas por Western-blot tanto en los extractos crudos como en las fracciones inmunoprecipitadas (Fig. S4). Esto puede deberse a diferentes modificaciones post-traduccionales de dichas proteínas o simplemente a reacciones inespecíficas de los anticuerpos. A pesar de identificar un buen número de proteínas, no encontramos ningún péptido nitrado que tuviera un espectro de MS/MS con un score suficientemente alto como para asignar algún sitio de nitración. Por tanto, las proteínas identificadas anteriormente solo pueden ser denominadas como putativamente nitradas. Para solucionar esto, y ya que la cantidad de proteína requerida para poder identificar sitios de nitración es siempre una limitación del método, las proteínas teñidas más abundantes en geles 2-DE resultantes de separar las proteínas immunoprecipitadas, fueron extraídas de los geles, digeridas con tripsina y analizadas mediante espectrometría de masas de tipo MALDI-TOF. En la tabla IV se muestran las proteínas identificadas, sus score MASCOT, el número de péptidos no redundantes identificados y la correspondiente cobertura de secuencia. Se identificaron 22 proteínas con un score MASCOT mayor de 59 que se consideró como estadísticamente significativo en el análisis.

\section{Tabla V. Proteínas putativamente nitradas identificadas por MALDI-TOF.}

Las muestras inmunoprecipitadas se separaron mediante geles 2-DE y se identificaron mediante MALDI-TOF como se describe en materiales y métodos. Se presenta la descripción, el identificador AGI, la masa teórica (Mr Teor), la masa experimental (Mr Exper), el tore MASCOT, el número de péptidos no redundantes identificados (Péptidos n.r.) y la cobertura de secuencia para cada una de las proteínas identificadas.

\begin{tabular}{|c|c|c|c|c|c|c|}
\hline Descripción & AGI & Mr Teor & Mr Exper & $\begin{array}{l}\text { Mascot } \\
\text { Score }\end{array}$ & $\begin{array}{l}\text { Péptidos } \\
\text { (n.r.) }\end{array}$ & $\begin{array}{l}\text { Cobertu } \\
\text { ra }(\%)\end{array}$ \\
\hline $\begin{array}{l}\text { Ribulosa bisfosfato carboxilasa, cadena } \\
\text { larga }\end{array}$ & AtCg00490 & 52.9 & 53.4 & 348 & 20 & 41 \\
\hline $\begin{array}{l}\text { Ribulosa bisfosfato carboxilasa/oxigenasa } \\
\text { activasa }\end{array}$ & At2g39730 & 52.0 & 52.3 & 251 & 14 & 50 \\
\hline Serina Hidroximetiltransferasa & At4g13930 & 51.7 & 52.1 & 238 & 11 & 25 \\
\hline $\begin{array}{l}\text { Gliceraldehido-3-fosfato deshidrogenasa, } \\
\text { citosólica }\end{array}$ & At3g04120 & 36.9 & 37.0 & 176 & 11 & 49 \\
\hline Proteína tipo chaperona & At5g55220 & 61.7 & 62.1 & 120 & 11 & 27 \\
\hline Proteína motor de microtúbulos & At5g60930 & 145.2 & 44.4 & 101 & 17 & 11 \\
\hline $\begin{array}{l}\text { Probable proteína de } 125 \mathrm{Kda} \text { relacionada } \\
\text { con la quinesina }\end{array}$ & At2g36200 & 119.3 & 120.4 & 81 & 23 & 26 \\
\hline Anhidrasa Carbónica cloroplástica & At3g01500 & 37.4 & 37.8 & 78 & 9 & 34 \\
\hline Hipotética proteína de 213.7 kDa ycf1.2 & AtCg01130 & 213.7 & 214.6 & 77 & 25 & 12 \\
\hline Proteína de reparación de DNA RAD50 & At2g31970 & 152.8 & 153.6 & 73 & 22 & 20 \\
\hline $\begin{array}{l}\text { Putativa proteína de la matríz nuclear } 1 \\
\text { (NMCP1-like) }\end{array}$ & At5g65770 & 121.2 & 121.8 & 70 & 21 & 17 \\
\hline
\end{tabular}




\begin{tabular}{|l|l|l|l|l|l|l|}
\hline Descripción & AGI & Mr Teor & Mr Exper & $\begin{array}{l}\text { Mascot } \\
\text { Score }\end{array}$ & $\begin{array}{l}\text { Péptidos } \\
\text { (n.r.) }\end{array}$ & $\begin{array}{l}\text { Cobertu } \\
\text { ra (\%) }\end{array}$ \\
\hline DNA topoisomerasa 1 & At5g55300 & 102.8 & 103.2 & 69 & 19 & 18 \\
\hline Tim9 & At3g46560 & 10.7 & 10.9 & 67 & 8 & 78 \\
\hline $\begin{array}{l}\text { Proteína 60S ribosomal L3-1 (Protein } \\
\text { EMBRYO DEFECTIVE 2207) }\end{array}$ & At1g43170 & 44.5 & 44.7 & 65 & 11 & 23 \\
\hline $\begin{array}{l}\text { Proteína de la familia Glicosil hidrolasa 1 } \\
\text { Proteína 7 de unión a RNA rica en glicina } \\
\text { (GRP7) }\end{array}$ & At5g25980 & 53.4 & 54.3 & 64 & 7 & 28 \\
\hline $\begin{array}{l}\text { Gliceraldehido-3-fosfato tore ión nada } \\
\text { C-2 }\end{array}$ & At1g13440 & 36.9 & 36.9 & 63 & 8 & 78 \\
\hline Putativa Transcetolasa & & & & & & 22 \\
\hline ARA-4 & At3g60750 & 79.9 & 80.3 & 62 & 12 & 34 \\
\hline Probable proteína nuclear de unión a GTP 1 & At1g50920 & 76.8 & 77.3 & 60 & 17 & 25 \\
\hline Probable manitol tore ión nada & At4g39330 & 38.9 & 39.3 & 59 & 8 & 26 \\
\hline $\begin{array}{l}\text { AIG1 } \\
\text { Arginina/serina RSP40 }\end{array}$ & At1g33960 & 40.1 & 40.3 & 59 & 13 & 34 \\
\hline
\end{tabular}

Desafortunadamente, no pudimos obtener ningún péptido nitrado con un espectro de MS/MS con suficiente score como para ser asignado con seguridad. Sin embargo, 6 de las 22 proteínas identificadas mostraron espectros de MALDI-TOF correspondientes a péptidos potencialmente nitrados con una ratio señal/ruido por encima de 25 , valor significativo en dicho análisis. La identificación de péptidos nitrados y sus formas no modificadas, junto con el tamaño de los péptidos identificados ( $\geq 7$ aminoácidos) hacen la identificación más fiable (Stevens et al., 2008). La Tabla $\mathrm{V}$ muestra la identidad de estas proteínas y los péptidos nitrados correspondientes con su valor de señal/ruido, la masa molecular del péptido modificado y no modificado encontrado en el mismo análisis y el correspondiente desplazamiento en masa correspondiente a la modificación de Y a nitroY. Tres de estas seis proteínas (Rubisco, Rubisco activasa y Transcetolasa) tenían péptidos nitrados que contenían una sola $\mathrm{Y}$ así que el desplazamiento en masa de +45 Dalton (Da) se podía asignar a dicha tirosina como un putativo sitio de nitración. En el caso de la Serina hidroximetiltransferasa, el péptido nitrado contenía dos residuos de tirosina y un desplazamiento de +90 Da lo que es compatible con dos sitios de nitración en dichas tirosinas. 
Tabla VI. Putativos péptidos nitrados identificados por MALDI-TOF a partir de proteínas separadas mediante 2-DE.

Proteínas inmunoprecipitadas con anti-3-NY se separaron en geles 2-DE y, tras tinción con Deep-Purple las proteínas más abundantes se identificaron mediante MALDI-TOF como se describe en Materiales y Métodos. Los identificadores de la iniciativa del genoma de Arabidopsis (AGI) de cada proteína identificada se incluyen junto a la secuencia del péptido nitrado correspondiente. Subrayados aparecen los residuos susceptibles de nitración y caracteres en negrita indican una asignación de nitración inequívoca. Se muestra el Error (diferencia entre las masas calculadas y las experimentales), la ratio Señal/Ruido, la masa molecular relativa (Mr) observada para los péptidos modificados y los respectivos no modificados, que aparecieron en la misma búsqueda Mascot. Valores entre paréntesis indican la ausencia del péptido no modificado. Se muestra también el Desplazamiento, en Daltons, y las modificaciones de los péptidos correspondientes con sus incrementos en masa entre paréntesis. Aquellas proteínas que han sido previamente reportadas como nitradas en plantas han sido marcadas con * (Chaki et al., 2009b) o ** (Cecconi et al., 2009).

\begin{tabular}{|c|c|c|c|c|c|c|c|c|}
\hline Descripción & AGI & $\begin{array}{l}\text { Secuencia del } \\
\text { Péptido }\end{array}$ & Error & $\begin{array}{l}\text { Señal/ } \\
\text { Ruido }\end{array}$ & $\begin{array}{c}\text { Mr (obs) } \\
\text { (no } \\
\text { modificado) }\end{array}$ & Mr (obs) & $\begin{array}{c}\text { Desplaza } \\
\text { miento }\end{array}$ & Modificación \\
\hline $\begin{array}{c}\text { Rubisco } \\
\text { activasa** }\end{array}$ & At2g39730 & $\begin{array}{c}{ }_{351} \text { R.VY } \\
{ }_{72} \text { R.GLAEVR.K }{ }_{359} \\
\text { QDITR.G }{ }_{88}\end{array}$ & $\begin{array}{l}0.01 \\
-0.05\end{array}$ & $\begin{array}{l}110 \\
25\end{array}$ & $\begin{array}{r}895.34 \\
1697.66\end{array}$ & $\begin{array}{c}940.41 \\
1744.66\end{array}$ & $\begin{array}{l}+45 \\
+47\end{array}$ & $\begin{array}{c}\text { Nitro-Y }(+45) \\
2 \\
\text { Deaminación } \\
(+2) \\
\text { Nitro- } Y(+45)\end{array}$ \\
\hline $\begin{array}{c}\text { Serina } \\
\text { Hidroximetil } \\
\text { transferasa }\end{array}$ & At4g13930 & $\begin{array}{c}{ }_{160} \text { K.VNFTTG } \underline{\mathbf{Y}} \text { ID } \underline{\mathbf{Y}} \\
\text { DKLEEK. } \mathrm{A}_{177}\end{array}$ & 0.03 & 60 & 1934.83 & 2025.92 & +91 & $\begin{array}{c}\text { Deaminación } \\
(+1) \\
2 \text { Nitro-Y } \\
(+90)\end{array}$ \\
\hline $\begin{array}{l}\text { Transcetolasa, } \\
\text { putativa* }\end{array}$ & At3g60750 & $\begin{array}{l}{ }_{333} \text { K.ANSYSVHGAA } \\
\text { LGEKEVEATR.N }_{354}\end{array}$ & 0.15 & 57 & $(2090.15)$ & 2135.15 & $(+45)$ & Nitro-Y $(+45)$ \\
\hline $\begin{array}{l}\text { Gliceraldehido-3- } \\
\text { fosfato } \\
\text { tore ión nada, } \\
\text { citosólica }\end{array}$ & At3g04120 & $\begin{array}{c}{ }_{313} \text { K.LVSWYYDNEW } \\
\text { GYYSSR.V } \\
328\end{array}$ & -0.06 & 50 & 1761.72 & 1806.72 & +45 & Nitro-Y $(+45)$ \\
\hline $\begin{array}{c}\text { Probable manitol } \\
\text { deshidrogenasa }\end{array}$ & At4g39330 & $\begin{array}{c}{ }_{133} \text { K.NYGGYSENIV } \\
\text { VDQR.F } \\
148\end{array}$ & -0.04 & 27 & 1613.63 & 1658.70 & +45 & Nitro-Y $(+45)$ \\
\hline $\begin{array}{l}\text { Rubisco, cadena } \\
\text { larga, precursor** }\end{array}$ & AtCg00490 & $\begin{array}{c}{ }_{236} \mathrm{~K} \text {.GHYYLNATAGT } \\
\text { CEEMIK. }_{253}\end{array}$ & 0.04 & 25 & (1794.84) & 1839.84 & $(+45)$ & Nitro-Y $(+45)$ \\
\hline
\end{tabular}

Finalmente, para las otras dos proteínas, una GAPDH citosólica y una putativa Manitol deshidrogenasa, los péptidos nitrados contuvieron dos residuos de tirosina y un desplazamiento de +45 Da, correspondiente a un solo evento de nitración así que no se puede proponer un sitio de nitración inequívoco para estas proteínas (Tabla V).

Tras este análisis, se comprobó si los residuos de $\mathrm{Y}$ presentes en los péptidos nitrados cumplían los diferentes criterios para ser considerados como dianas de nitración, basados en las características comunes de los péptidos nitrados identificados en diferentes trabajos (Souza et al., 1999; Ischiropoulos 2003; Chaki et al., 2009b). Estos son, la proximidad a un aminoácido básico en la secuencia primaria, la exposición del anillo aromático de la Y a la superficie de la proteína, la localización de la $\mathrm{Y}$ en un bucle, su asociación con un residuo cargado negativamente en su proximidad en la estructura terciaria de la proteína, y la localización de la proteína en un compartimento subcelular que produzca agentes nitrantes (Souza et al., 1999; Ischiropoulos 2003; 
Chaki et al., 2009b). Con la excepción de la Rubisco activasa, de la que se carece de algún modelo estructural depositado en las bases de datos, las estructuras de las proteínas se modelaron como se indica en la sección de Materiales y Métodos. Todos los residuos de Y posiblemente nitrados se encuentran suficientemente cerca de un residuo cargado negativamente (a menos de 10 Amstrongs (Å) de la Y diana) y todos ellos tienen aminoácidos básicos flanqueando el residuo de Y (Tabla VI). Sin embargo, solo la Y337 y la Y135 de la Transcetolasa y la putativa Manitol deshidrogenasa, respectivamente, se encontraron en bucles y muchas de estas proteínas mostraron un índice de Área Accesible al Solvente (ASA) por debajo de 70 (Tabla VI), teniendo una baja probabilidad de estar expuestas al solvente.

Tabla VII. Características estructurales de las potenciales Y dianas de nitración en las proteínas identificadas por MALDI-TOF.

Se indica la anotación de la proteína y su código AGI junto con la posible Y nitrada. Los diferentes parámetros fueron calculados como se indica en Materiales y Métodos. El Área Accesible al Solvente (ASA) se calculó con el programa NetSurfP (Petersen et al., 2009)

\begin{tabular}{|c|c|c|c|c|c|}
\hline Proteína/AGI & $\begin{array}{c}\text { Posible Y } \\
\text { Nitrada }\end{array}$ & $\begin{array}{c}\text { Distancia a } \\
\text { Asp(D)/Glu€ }\end{array}$ & $\begin{array}{c}\text { Amino ácidos básicos } \\
\text { próximos en la secuencia } \\
\text { primaria }\end{array}$ & Bucle & ASA \\
\hline $\begin{array}{c}\text { Rubisco activasa } \\
\text { At2g39730 }\end{array}$ & $\begin{array}{l}\text { Y353 } \\
\text { Y76 }\end{array}$ & (sin modelo) & $\begin{array}{c}\mathrm{R} 351, \mathrm{R} 358, \mathrm{~K} 359 \\
\text { R72 }\end{array}$ & $\begin{array}{c}(\sin \\
\text { modelo })\end{array}$ & $\begin{array}{r}5.45 \\
79.13\end{array}$ \\
\hline $\begin{array}{c}\text { Serina Hidroximetil } \\
\text { transferasa_At4g13930 }\end{array}$ & $\begin{array}{l}\text { Y167 } \\
\text { Y170 }\end{array}$ & $\begin{array}{l}5.99 \AA \text { a E342 } \\
5.04 \AA \text { a D197 }\end{array}$ & $\begin{array}{l}\text { K160, K172, K176 } \\
\text { K160, K172, K176 }\end{array}$ & $\begin{array}{l}\text { No } \\
\text { No }\end{array}$ & $\begin{array}{l}62.38 \\
23.35\end{array}$ \\
\hline $\begin{array}{c}\text { Transcetolasa, putativa } \\
\text { At3g60750 }\end{array}$ & Y337 & $9.01 \AA \AA$ a D268 & K333, H340, K347 & $\mathrm{Si}$ & 66.16 \\
\hline $\begin{array}{l}\text { Gliceraldehido-3-fosfato } \\
\text { deshidrogenasa, } \\
\text { citosólica_At3g04120 }\end{array}$ & $\begin{array}{l}\text { Y318 } \\
\text { Y324 }\end{array}$ & $\begin{array}{l}6.08 \AA \text { a D319 } \\
6.61 \AA \AA \text { a E321 }\end{array}$ & $\begin{array}{l}\text { K313, R327 } \\
\text { K313, R327 }\end{array}$ & $\begin{array}{l}\text { No } \\
\text { No }\end{array}$ & $\begin{array}{c}7.35 \\
19.17\end{array}$ \\
\hline $\begin{array}{l}\text { Probable Manitol } \\
\text { deshidrogenasa_ } \\
\text { At4g39330 }\end{array}$ & $\begin{array}{l}\text { Y135 } \\
\text { Y138 }\end{array}$ & $\begin{array}{l}4.31 \AA \text { to E8 } \\
3.75 \AA \text { tu D53 }\end{array}$ & $\begin{array}{l}\text { K133, R147 } \\
\text { K133, R147 }\end{array}$ & $\begin{array}{c}\mathrm{Si} \\
\text { No }\end{array}$ & $\begin{array}{l}34.66 \\
13.55\end{array}$ \\
\hline $\begin{array}{l}\text { Rubisco cadena larga, } \\
\text { precursor_AtCg00490 }\end{array}$ & Y239 & $6.33 \AA \AA$ a E158 & K236, H238, K252, R253 & No & 6.37 \\
\hline
\end{tabular}

En cuanto a la proximidad de las proteínas al sitio de generación de especies nitrantes, la localización de todas las proteínas ha sido descrita en sitios previamente caracterizados como sitios de producción de NO y superóxido en plantas, como el apoplasto, la mitocondria y el cloroplasto (Corpas et al., 2001; Bethke et al., 2004a; Gupta et al., 2005; Jasid et al., 2006; Flores-Perez et al., 2008; Igamberdiev y Hill 2009). Además, el hecho de que algunos de los residuos de Y identificados como posiblemente nitrados estén altamente conservados en proteínas funcionalmente homólogas de otros organismos (Fig. S2), confiere una potencial relevancia 
funcional a esta modificación post-traduccional como un mecanismo regulatorio de su actividad o función.

Para comprobar esto, estudiamos el impacto de un donador de peroxinitrito, como SIN-1, en la actividad de la proteína GAPDH. Así, confirmamos que el tratamiento de plantas con SIN-1 da lugar a la inhibición de la actividad GAPDH (Fig. 38). A pesar de los esfuerzos realizados para identificar sitios de nitración in vivo en las proteínas immunoprecipitadas con anticuerpos anti-3nitroY, no hemos podido identificar ningún espectro de MS/MS correspondiente a ningún péptido nitrado. Esto puede explicarse por dos razones. Primero, la forma nitrada de las proteínas que se identificaron pudo ser muy poco abundante en las muestras analizadas haciendo la identificación por MS/MS extremadamente difícil. Segundo, la ausencia de péptidos nitrados identificados pudo ser el resultado de su naturaleza inestable bajo las condiciones utilizadas para el procesamiento de las muestras por MS. En cuanto a esto, ha sido descrito que el grupo nitro asociado a residuos de tirosina puede ser reducido a un grupo amino (Sarver et al., 2001; Tsumoto et al., 2010). Cuando se analizaron los datos obtenidos en los experimentos de espectrometría de masas correspondientes a los spots de los geles 2-DE, buscando la modificación post-traduccional aminoY en vez de nitroY, encontramos un espectro de MS/MS correspondiente al péptido LVSWYDNEWGYSSR (masa monoisotópica del péptido 1776,7631; score del ion 43; valor "expect" $(0,00088)$ de la proteína GAPDH. Este péptido tiene un desplazamiento de masa de +15 Da compatible con una aminación en la Y318 (Fig. 38).

A

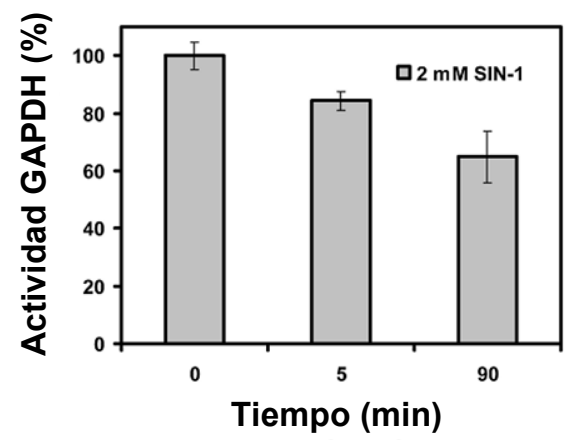

B

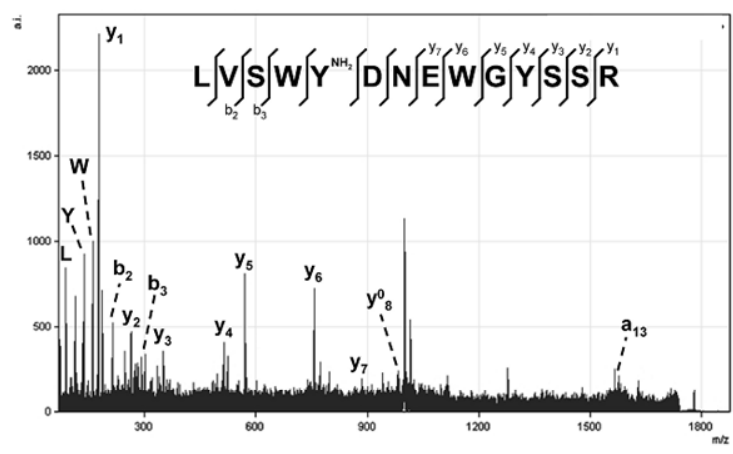

Figura 38. Efecto de la nitración de GAPDH.

A. Se midió la actividad GAPDH en plantas de Arabidosis tratadas con el donador de peroxinitrito, SIN-1, tras los tiempos indicados como se describe en Materiales y Métodos. Las medidas de actividad se realizaron por triplicado, representando los valores medios \pm desviación estándar. B. Espectro de MS/MS correspondiente al péptido aminado de la GAPDH, LVSWY*DNEWGYSSR. Se señalan los picos detectados de las series y y b asi como los iones imonio de L, Y y W.

Este dato sugiere que de las dos tirosinas que encontramos como potenciales dianas de nitración en GAPDH (Tabla V), parte de la 3-nitroY318 puede haberse reducido a 3-aminoY318 
en las condiciones del análisis por espectrometría de masas. Como la reducción puede darse en cualquiera de los residuos de nitroY, re-analizamos los datos de LC-MS/MS buscando la modificación aminoY y encontramos 51 posibles péptidos que contenían 3-aminoY con score de ión por encima de 15 que correspondían con 47 proteínas diferentes (Tabla S2). La comparación de las búsquedas con nitroY y con aminoY resultó en solo 5 péptidos con ambas modificaciones en el mismo residuo pero todos ellos tenían score de ión por debajo de 10, sugiriendo que la reducción parcial de nitroY puede reducir la abundancia de ambas modificaciones haciendo la identificación mediante MS todavía más difícil.

\section{El análisis de ontología génica apunta a enzimas del metabolismo primario y proteínas} estructurales del citoesqueleto como dianas generales de nitración en Arabidopsis

Usando las herramientas de ontología génica (GO), ProfCom, para el análisis de las proteínas identificadas como potencialmente nitradas, encontramos que la mayoría de las proteínas identificadas se localizan en orgánulos subcelulares asociados a membranas. Existe una sobrerepresentación significativa de proteínas de la membrana de los tilacoides y del estroma de los cloroplastos, peroxisomas, mitocondrias y apoplasto entre las proteínas identificadas (Tabla VII). Cabe remarcar que estos orgánulos han sido todos ellos descritos como sitios donde se produce NO y superóxido en plantas (Corpas et al., 2001; Bethke et al., 2004a; Gupta et al., 2005; Jasid et al., 2006; Flores-Perez et al., 2008; Antonov et al., 2008; Igamberdiev y Hill 2009). En cuanto a la función molecular, las herramientas de GO apuntan a proteínas del citoesqueleto así como a proteínas con actividad ATPasa asociada al transporte de moléculas a través de la membrana plasmática como dianas generales de la nitración de proteínas en Arabidopsis (Tabla VII). Muchas de las proteínas identificadas están relacionadas con procesos biológicos como las respuestas a temperatura, luz o cadmio (Tabla VII). Además, más del $60 \%$ de las proteínas identificadas en nuestro análisis proteómico están relacionadas con el metabolismo primario. Entre estas proteínas, encontramos siete enzimas de la ruta de gluconeogénesis que dan lugar a la síntesis de sacarosa, así como cinco enzimas de la ruta de salida del ciclo de Calvin que da lugar a hidroxipiruvato (Tabla III). Aún más destacado, tres de los cuatro enzimas que participan en el ciclo de la síntesis de metionina se encontraron también en las muestras immunoprecipitadas (Tabla III). Todos estos datos indican que las dianas de la nitración de proteínas, en condiciones basales, son, mayoritariamente, las proteínas estructurales y los enzimas del metabolismo primario. 
Tabla VIII Enriquecimiento en categorías de Ontología Génica (GO) entre las proteínas nitradas.

El grupo de proteínas nitradas identificadas (Set A, dos proteínas de las 127 identificadas no estaban presentes en la base de datos) fue comparado con todo el genoma (Set B) con la herramienta ProfCom (http://webclu.bio.wzw.tum.de/profcom/; (Antonov et al., 2008) usando bases de datos de Arabidopsis.

\begin{tabular}{|c|c|c|c|c|c|c|}
\hline Valor-P & $\begin{array}{c}\text { SET A } \\
\text { estadística }\end{array}$ & $\begin{array}{l}\text { SET A } \\
\text { tamaño }\end{array}$ & $\begin{array}{c}\text { SET B } \\
\text { estadística }\end{array}$ & $\begin{array}{c}\text { SET B } \\
\text { tamaño }\end{array}$ & $\begin{array}{l}\text { Categoría y } \\
\text { código }\end{array}$ & Nombre de categoría \\
\hline & & & & & $\begin{array}{c}\text { Compartimento } \\
\text { Celular }\end{array}$ & \\
\hline $2.1 \mathrm{e}-10$ & 13 & 125 & 248 & 27072 & GO:0009535 & membrana del tilacoide \\
\hline $2.8 \mathrm{e}-10$ & 10 & 125 & 114 & 27072 & GO:0005777 & peroxisoma \\
\hline $3.5 \mathrm{e}-09$ & 11 & 125 & 200 & 27072 & GO:0009570 & estroma \\
\hline $9.6 \mathrm{e}-09$ & 10 & 125 & 169 & 27072 & GO:0048046 & apoplasto \\
\hline \multirow[t]{2}{*}{$6.5 \mathrm{e}-08$} & 18 & 125 & 866 & 27072 & GO:0005739 & mitocondria \\
\hline & & & & & $\begin{array}{l}\text { Función } \\
\text { Molecular }\end{array}$ & \multirow{4}{*}{$\begin{array}{c}\text { constituyente estructural } \\
\text { del citoesqueleto } \\
\text { actividad ATPasa } \\
\text { acoplada a movimiento } \\
\text { transmembrana de } \\
\text { sustancias } \\
\end{array}$} \\
\hline $2.4 \mathrm{e}-07$ & 5 & 125 & 25 & 27072 & GO:0005200 & \\
\hline \multirow[t]{2}{*}{$8.1 \mathrm{e}-06$} & 6 & 125 & 98 & 27072 & GO:0042626 & \\
\hline & & & & & $\begin{array}{l}\text { Proceso } \\
\text { Biológico }\end{array}$ & \\
\hline $1.8 \mathrm{e}-21$ & 20 & 125 & 177 & 27072 & GO:0009409 & respuesta a frío \\
\hline $5.7 \mathrm{e}-08$ & 8 & 125 & 107 & 27072 & $\underline{\mathrm{GO}: 0009416}$ & $\begin{array}{c}\text { respuesta a estímulo } \\
\text { lumínico }\end{array}$ \\
\hline $1.1 \mathrm{e}-05$ & 6 & 125 & 103 & 27072 & GO:0009408 & respuesta a calor \\
\hline $7.6 \mathrm{e}-05$ & 6 & 125 & 150 & 27072 & GO:0046686 & respuesta a cadmio \\
\hline
\end{tabular}

\section{Identificación del sitio de nitración de la Metionina Sintasa 1}

Para solucionar la baja abundancia de las formas nitradas de las proteínas que podemos encontrar in vivo, una de las proteínas identificadas como potencialmente nitrada en nuestra 
búsqueda, la 5-metiltetrahidropteroiltriglutamato-homocisteina-S-metiltransferasa o Metionina sintasa 1 (AtMS1), se expresó etiquetada con 6 Histidinas (6xHis) en bacteria. La proteína se expresó a niveles altos tras 5 horas de inducción con IPTG. Tras examinar la expresión de la proteína en extractos crudos de la bacteria inducida mediante Western-blot con anticuerpos antiHis, se procedió a purificar la proteína mediante columnas de níquel. Tras purificar la proteína, se dividió en dos partes equivalentes nitrando una de las fracciones in vitro mientras que la otra se sometió a un tratamiento control. La eficiencia de la nitración se comprobó mediante Western-blot con anticuerpos anti-3-nitroY. No se detectó ninguna banda que reaccionara con el anticuerpo en el caso del tratamiento control mientras que una señal muy intensa se detectó en el tratamiento nitrante (Fig. 39A). Ambas muestras presentaron niveles comparables de la proteína recombinante como se pone de manifiesto en el Western-blot anti-His (Fig. 39A). Se realizó un duplicado del gel y se tiñó con Coomassie y la banda correspondiente a la proteína recombinante AtMS1 nitrada y no nitrada se recortó del gel, se digirió con tripsina y se analizó mediante LC-MS/MS. Encontramos el mismo péptido, YLFAGVVDGR, de la proteína no nitrada (masa molecular 1096,58; score MASCOT 85) y la nitrada (masa molecular 1141,54; score MASCOT 53), mostrando un desplazamiento de masa de 44,96 Da equivalente al típico desplazamiento correspondiente a una nitración (Fig. 39C). El espectro de MS/MS del péptido nitrado contiene la mayoría de los picos correspondientes a las series de iones $y$ y $b$ junto con el correspondiente ión imonio nitrado de la Y287 (Fig. 39B). Estos datos permitieron la identificación inequívoca de un sitio de nitración en la proteína AtMS1 en el residuo Y287.

A

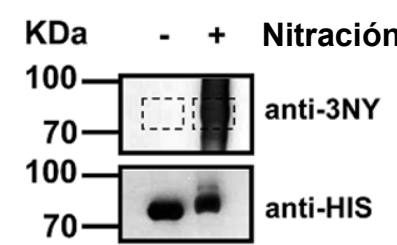

B

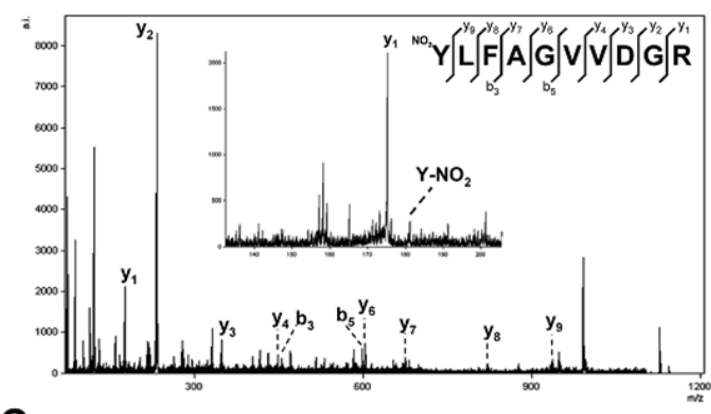

C

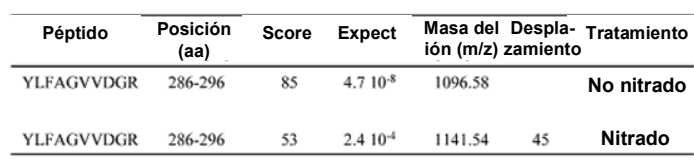

Figura 39. Identificación del sitio de nitración de la Metionina Sintasa 1 de Arabidopsis.

A. La misma cantidad de proteína $(5 \mu \mathrm{g})$ fué nitrada $(+)$ o no (-), separada por SDS-PAGE, transferida a membrana e incubada con anticuerpo anti-3-NY. Tras revelar, se eliminó el anticuerpo unido y se rehibridó la membrana con anticuerpo anti-histidina (anti-HIS). Se muestra la posición de los marcadores de peso molecular. B. Espectro de MS/MS del péptido nitrado Y*LFAGVVDGR de AtMS1. La serie de iones y y $b$ se muestra junto con la ampliación del espectro mostrando el ión imonio de la Y nitrada. C. Tabla resumiendo los datos de MS correspondientes al péptido nitrado y no nitrado de AtMS1. 
Si esta modificación post-traduccional altera la actividad enzimática de AtMS1, su localización subcelular u otras posibles modificaciones post-traduccionales requiere más trabajo que se realizará en un futuro. De todas formas, la Y287 está conservada dentro de las Metioninas Sintasas de plantas pero no en levaduras (Fig. S3A), y está localizada en un bucle de la parte externa de la proteína lejos de los sitios de unión del 5-metiltetrahidropteroiltriglutamato (THG) y de la homocisteina al centro catalítico (Fig. S3B). La Y287 forma un puente de hidrógeno con dos residuos cercanos, T262 y F264, que pueden tener un papel importante en el mantenimiento del correcto plegamiento de la proteína pero que no tienen un papel importante en la unión del sustrato ni de la función del cofactor. Sin embargo, ha sido descrito que la actividad metionina sintasa se regula por NO. El tratamiento con NO reduce la actividad metionina sintasa en diferentes sistemas modelo tanto in vitro (Brouwer et al., 1996; Nicolaou et al., 1996; Nicolaou et al., 1997) como in vivo (Danishpajooh et al., 2001), sugiriendo que la nitración en tirosina puede ser responsable de la reducción de la actividad mediada por NO de este enzima.

\section{DISCUSIÓN}

Aunque en la última década se han publicado varios trabajos sobre aproximaciones proteómicas para la identificación de proteínas nitradas en mamíferos (Aulak et al., 2001; Suzuki et al., 2005; Sultana et al., 2006; Hong et al., 2007; Zhang et al., 2007b), los primeros dos trabajos centrados en este esta área, en plantas, no han sido publicados hasta mediados del 2009 (Cecconi et al. 2009; Chaki et al. 2009b). En estos trabajos, ambos grupos describen el uso de anticuerpos anti3-nitroY para la detección de proteínas posiblemente nitradas por Western-blot y su posterior identificación por MALDI-TOF/TOF, identificando 8 y 21 proteínas, respectivamente (Cecconi et al. 2009; Chaki et al. 2009b). Sin embargo, no se identificó ningún péptido nitrado y por lo tanto, ningún sitio de nitración, en ninguno de estos dos trabajos, probablemente por el bajo nivel de nitración que se da en condiciones de ausencia de estrés (Chaki et al. 2009b), y por las limitaciones técnicas (Cecconi et al. 2009) tal y como argumentan los autores. En este trabajo, hemos puesto a punto una metodología proteómica para purificar e identificar proteínas nitradas in vivo en residuos de Y de Arabidopsis thaliana. El método se basa en la purificación de proteínas nitradas mediante inmunoprecipitación con anticuerpos anti-3-nitroY bien caracterizados anteriormente (Schmidt et al., 2003; Gokulrangan et al., 2007) y la posterior identificación de las proteínas por LC-MS/MS. Este procedimiento ha sido utilizado con éxito en la identificación de proteínas nitradas de mamíferos anteriormente (Turko et al., 2003; Zhan y Desiderio 2009; Liu et al., 2009a). El método es suficientemente sensible como para identificar 127 proteínas potencialmente nitradas en plántulas de Arabidopsis. Estos resultados, están en el rango de los mejores métodos proteómicos para la identificación de proteínas nitradas descritos en modelos animales (Suzuki et 
al., 2005; Sultana et al., 2006; Hong et al., 2007; Zhang et al., 2007b), y representa la descripción más extensa del proteóma nitrado hasta la fecha en plantas. Mediante una búsqueda bibliográfica pudimos comprobar que alrededor del $35 \%$ de las proteínas identificadas en este trabajo han sido descritas como nitradas en otros organismos diferentes a las plantas (Tabla S1 y sus referencias), lo que apoya la utilidad de este método para identificar proteínas potencialmente nitradas. Además, el $50 \%$ y el $28 \%$ de las proteínas identificadas como posiblemente nitradas en los otros dos trabajos en modelos vegetales (Cecconi et al. 2009; Chaki et al. 2009b), respectivamente, han sido también identificadas en nuestro trabajo. Por otro lado, hemos validado algunas de nuestras identificaciones mediante la detección de las correspondientes proteínas en Western-blot con anticuerpos específicos (Fig. 37). Aunque la metodología presentada en este trabajo parece ser suficientemente fiable y robusta para ser considerada como un buen punto de partida para la caracterización de las proteínas nitradas de plantas, no encontramos ningún sitio inequívoco de nitración por MS/MS. Debido a la baja abundancia de los residuos de $\mathrm{Y}$ en las proteínas y a que los residuos nitrados de tirosina están restringidos a uno o dos por proteína (Abello et al., 2009), es de esperar un número muy pequeño de eventos de nitración. Así las proteínas más abundantes de geles 2-DE de muestras inmunoprecipitadas con anticuerpos anti-3-nitroY se analizaron en la búsqueda de Y nitradas. De esta manera, identificamos péptidos nitrados de las proteínas GAPDH, RuBisCO; RuBisCO activasa, Manitol deshidrogenasa y Transcetolasa (Tabla V). Las identificaciones están basadas en los datos de huella peptídica obtenida por MALDI-TOF ya que no se encontró ningún espectro MS/MS de fragmentación que incluyera algún péptido nitrado. Se seleccionaron solo los péptidos con una ratio señal/ruido $\geq 25$ y una diferencia entre la masa calculada y la experimental menor de 0.15 Da. Además, el análisis in silico de los péptidos nitrados mostró que la mayoría de ellos cumplían muchos de los criterios para ser considerados como dianas de nitración (Tabla VI). El análisis de Ontología Génica (GO) de las proteínas identificadas mostró una sobre-representación de proteínas localizadas en cloroplastos, peroxisomas, mitocondria y apoplasto, compartimentos subcelulares descritos previamente como sitios de producción de agentes nitrantes en plantas (Jasid et al. 2006; Flores-Pérez et al. 2008; Corpas et al. 2001; Bethke et al. 2004a; Gupta et al. 2005 e Igamberdiev y Hill 2009). Estos datos apoyan la idea propuesta anteriormente de que la proximidad de las proteínas al sitio de generación de agentes nitrantes supone un determinante de su nitración (Ischiropoulos 2003).

Además, la relevancia funcional de esta modificación post-traduccional en dichas dianas es también apoyada por el hecho de que la mayor parte de los residuos de $\mathrm{Y}$ identificados como potencialmente nitrados están conservados en la secuencia de aminoácidos de proteínas homólogas de otros organismos (Fig. S2), apoyando así un posible efecto funcional de esta modificación. En el caso de la GAPDH, los dos residuos identificados como nitrados en el péptido LVSWY*DNEWGY*SSR no solamente están conservados en la GAPDH de conejo, sino que han sido identificados como nitrados en el péptido correspondiente de conejo LISWY*DNEFGY*SNR 
y, además, su nitración resulta en una pérdida completa de la actividad de dicha proteína (Palamalai y Miyagi 2010). Los modelos estructurales de GAPDH de rata y Arabidopsis solapan bastante, sobretodo en las Y nitradas (Fig. 40). Además, tal y como se ha descrito en levadura y en mamíferos (Buchczyk et al., 2000; Palamalai y Miyagi 2010), la actividad GAPDH de Arabidopsis también se inhibe por peroxinitrito (Fig. 38A).
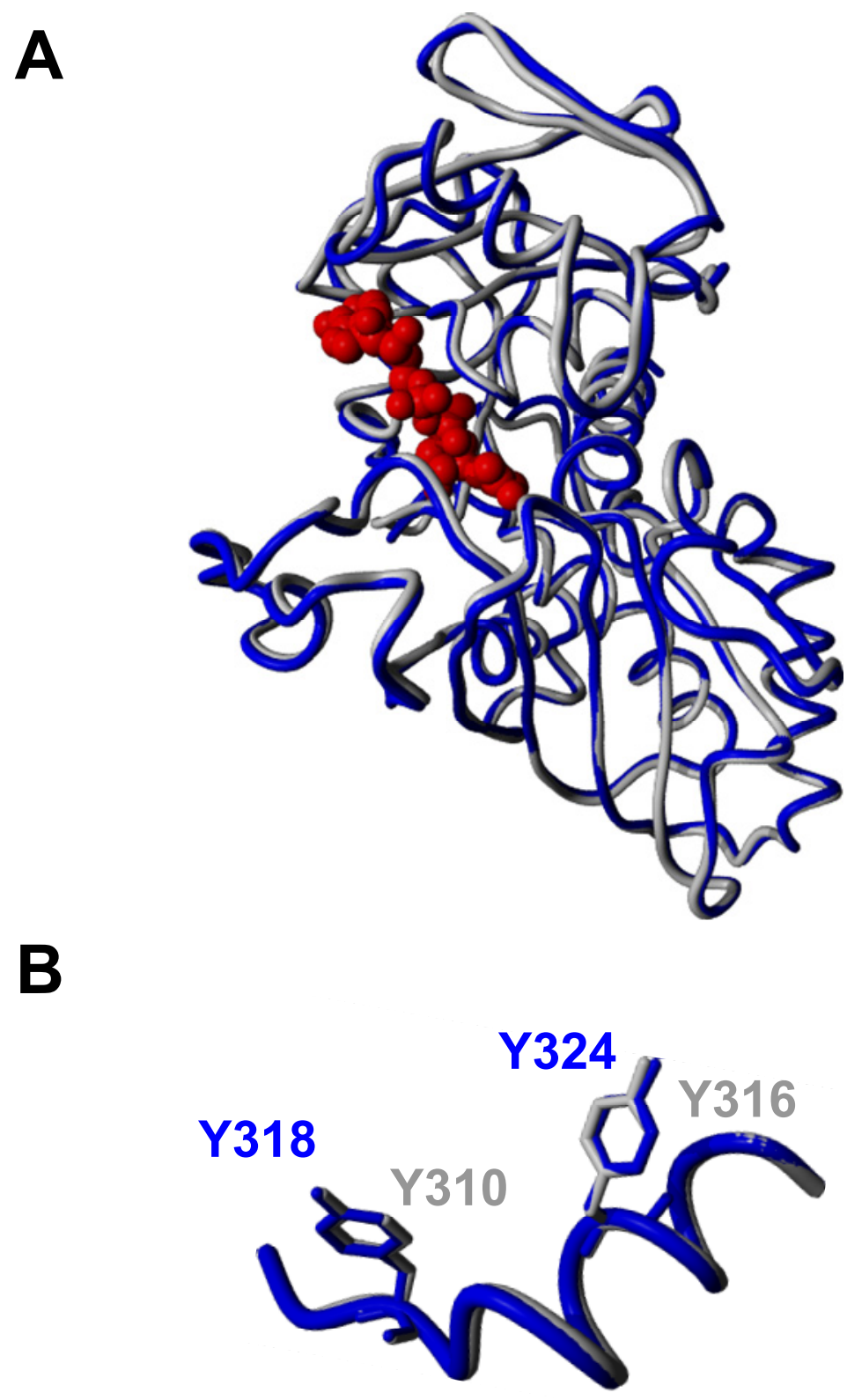

Figura 40. El alineamiento estructural de los modelos de la GAPDH de Rata y Arabidopsis muestra una clara conservación.

A. Alineamiento estructural de la proteína GAPDH completa de Rata (gris) y Arabidopsis (azul) con NAD unido (rojo). B. Detalle mostrando el alineamiento de las Y310 y Y316 de la GAPDH de Rata (gris) y las Y318 y Y324 de Arabidopsis (azul). 
Resulta interesante, que varias proteínas, que participan junto con GAPDH en la conversión gluconeogénica de malato a sacarosa, han sido también identificadas como posiblemente nitradas en este trabajo, sugiriendo un posible papel regulatorio de la nitración de $\mathrm{Y}$ en esta ruta metabólica. Entre las posibles proteínas nitradas, encontramos también tres enzimas relacionadas con la síntesis de metionina: la 5-metil-tetrahidropteroiltriglutamato-homocisteinametiltransferasa, también denominada como metionina sintasa, la S-adenosilmetionina sintetasa 1 y la 2 y la Sadenosilhomocisteinasa 1. Ha sido descrito previamente que el NO puede inhibir la actividad metionina sintasa de mamíferos mediante la reacción con el cofactor cobalamina (Brouwer et al., 1996; Nicolaou et al., 1996; Nicolaou et al., 1997; Danishpajooh et al., 2001). De todas formas, teniendo en cuenta los resultados obtenidos en este trabajo, este modo de acción del NO es compatible con el mecanismo de control de la actividad metionina sintasa por nitración de Y clave de la proteína. Además, el hecho de que no solo un paso clave sino que la mayoría de las enzimas relacionadas con la síntesis de metionina sean dianas potenciales de nitración en Arabidopsis sugiere que la nitración de Y pueda representar un nivel importante de regulación para controlar la síntesis de este aminoácido en plantas. Además, la nitración de las S-adenosilmetionina sintasas 1 y 2 puede representar un importante punto de control sobre la síntesis de etileno. En cuanto a esto, ha sido descrito que la nitrosilación en cisteinas de la S-adenosilmetionina sintasa 1 resulta en una reducida actividad del enzima y en una menor producción de etileno en Arabidopsis (Lindermayr et al. 2006).

El hecho de que ni en este trabajo ni en los dos trabajos publicados previamente sobre la identificación de proteínas nitradas en plantas (Cecconi et al. 2009; Chaki et al. 2009b) se haya identificado ningún sitio de nitración de manera inequívoca necesita de una discusión en profundidad. Se sabe que la nitración de $\mathrm{Y}$ es una modificación post-traduccional muy poco abundante comparada con otras modificaciones post-traduccionales como la fosforilación (Abello et al. 2009). Además, es muy posible que en condiciones de ausencia de estrés, donde se producen cantidades muy pequeñas de NO y de ión superóxido y, por lo tanto, donde se producen pequeñas cantidades de peroxinitrito, se pueda esperar una baja abundancia de la nitración de Y. En cualquier caso, ya que la metodología presentada en este trabajo enriquece las muestras en proteínas que contengan 3-nitroY deberíamos esperar la identificación de péptidos nitrados por MS/MS. Una búsqueda en la bibliografía sobre la identificación de proteínas nitradas en diferentes organismos nos indica que solo se ha identificado un número muy pequeño de sitios de nitración, comparado con el número de proteínas nitradas identificadas, sugiriendo la existencia de dificultades técnicas asociadas a los análisis basados en MS de esta clase de modificación. Una posible explicación de la ausencia de nitroY en las muestras puede estar relacionada con las alteraciones producidas por los tratamientos que se realizan antes del análisis por espectrometría de masas o durante la ionización de los péptidos. Ha sido descrito que el tratamiento de proteínas nitradas con el reductor DTT acompañado por una temperatura elevada, como la que se usa para la 
digestión de las proteínas con tripsina, puede reducir los residuos de nitroY a aminoY o a otras especies relacionadas (Soderling et al., 2007). Además, las energías de ionización utilizadas por los sistemas MALDI o ESI son demasiado agresivas para los residuos nitrados, habiendo sido documentada la descomposición fotoquímica inducida por láser de residuos de nitroY a aminoY durante los análisis de tipo MALDI (Sarver et al., 2001). Por tanto, la conversión de nitroY a aminoY durante el procesamiento de las muestras antes y durante el análisis MS puede explicar la ausencia de la detección de péptidos nitrados mediante MS/MS. Para validar esta hipótesis buscamos en nuestros datos proteómicos la modificación aminoY. Seleccionando aminoY como modificación variable en el análisis MASCOT de los datos en los experimentos de MALDITOF/TOF, encontramos un espectro de MS/MS correspondiente a un péptido que contenía aminoY correspondiente a la proteína GAPDH (Fig. 38B). Concretamente, encontramos un péptido que contenía aminoY318, sugiriendo que de los dos residuos de $\mathrm{Y}$ que encontramos como posiblemente nitrados en GAPDH (Tabla V), parte del residuo nitroY318 ha sufrido una reducción a aminoY318 durante las condiciones del análisis MS. Además, aunque no encontramos ningún espectro más de MS/MS correspondiente a péptidos con aminoY, encontramos alrededor de 50 péptidos que contenían potencialmente aminoY con un score MASCOT de ión mayor de 15 (Tabla S2). Esto confirma la hipótesis de que la ausencia de la identificación de péptidos nitrados en este trabajo, y probablemente en otros, puede ser debida a la conversión de nitroY a aminoY. Esta conclusión lleva a proponer la idea de buscar nitroY y aminoY como modificaciones variables en trabajos futuros donde se quieran identificar sitios de nitración en las proteínas. Eventualmente, la reducción de todos los residuos de nitroY a aminoY mediante un reductor como el ditionito sódico antes del análisis MS puede representar una ventaja en el análisis proteómico buscando directamente aminoY, o bien derivatizando la aminoY (por ejemplo con biotina) y buscando posteriormente los péptidos derivatizados por MS (Ghesquiere et al., 2009; Abello et al., 2010).

El método proteómico descrito en este trabajo representa una herramienta para identificar proteínas que sufren nitración en Y in vivo en plantas. La aplicación de esta metodología, con las mejoras descritas anteriormente, al análisis de diferentes procesos biológicos en plantas permitirá la identificación de proteínas nitradas en $\mathrm{Y}$ así como su sitio de nitración. Debido a la baja abundancia y a la limitada estabilidad de esta modificación post-traduccional, los datos obtenidos sugieren que tras la identificación de dianas de nitración in vivo, la confirmación de los sitios de nitración y las consecuencias funcionales deben ser realizadas mediante ensayos in vitro con cantidades mucho mayores de proteína modificada. Esto se ha puesto claramente de manifiesto con el estudio del impacto de la nitración sobre el enzima OAS-TL A1 que hemos realizado en colaboración con el grupo de Cecilia Gotor (IBVF, Sevilla). El impacto de la nitración en la actividad de esta proteína, identificada en primera instancia en este trabajo, mediante aproximaciones tanto in vitro como in vivo ha permitido describir la $\mathrm{Y}$ diana de la nitración, así como el mecanismo por el que dicha nitración reduce la actividad del enzima, representando el 
primer trabajo en el que se ha identificado un sitio inequívoco de nitración con impacto funcional caracterizado en una proteína de plantas (Alvarez et al., 2011). En cualquier caso, las proteínas identificadas en este trabajo pueden representar nuevos nodos de un nuevo nivel de regulación todavía por explorar, llevado a cabo a través de la modificación post-traduccional de proteínas mediada por NO. La caracterización en profundidad de las proteínas nitradas identificadas en este trabajo aportará más información sobre las características reguladoras del NO en muchos aspectos del crecimiento y desarrollo de las plantas así como en procesos de respuesta a estrés. 


\section{DATOS SUPLEMENTARIOS}

Tabla S1. Proteínas identificadas como putativamente nitradas en Arabidopsis y los correspondientes homólogos funcionales identificados como nitrados en otros sistemas diferentes a las plantas.

Se muestran las proteínas identificadas por LC-MS/MS en Arabidopsis (izquierda), los homólogos funcionales en otros sistemas (centro) y la referencia correspondiente (derecha).

\begin{tabular}{|c|c|c|}
\hline $\begin{array}{l}\text { Proteína identificada } \\
\text { (AGI locus) }\end{array}$ & Proteína (Organismo) & Referencias \\
\hline TCPA_ARATH (At3g20050) & $\begin{array}{l}\text { subunidad alfa TCP-1 complejo-T polipéptido } 1 \\
\text { (Rata; Humano) }\end{array}$ & $\begin{array}{l}\text { Suzuki et al., } 2005 \\
\text { Guesquière et al., } 2009\end{array}$ \\
\hline G3PB_ARATH (At1g42970) & Gliceraldehido-3-fosfato dehidrogenasas & Sultana et al., 2006 \\
\hline G3PA_ARATH (At3g26650) & (Humano; Rata) & Guesquière et al., 2009 \\
\hline \multicolumn{3}{|l|}{ G3PC_ARATH (At3g04120) } \\
\hline ATPA_ARATH (AtCg00120) & ATP sintasas (Humano ; Ratón) & Casoni et al., 2005; Sultana \\
\hline ATPB ARATH (AtCg00480) & & et al., 2006; Zhang et al., \\
\hline \multicolumn{3}{|l|}{ ATPG $\overline{1} \_$ARATH (At4g04640) } \\
\hline \multicolumn{3}{|l|}{ VATB_ARATH (At1g76030) } \\
\hline CAHC_ARATH (At3g01500) & Anhidrasas Carbónicas (Humano) & Sultana et al., 2006 \\
\hline \multicolumn{3}{|l|}{ CAH2_ARATH (At5g14740) } \\
\hline ENO_ARATH (At2g36530) & Enolasa (Ratón; Humano) & $\begin{array}{l}\text { Casoni et al., 2005; Sultana } \\
\text { et al., } 2006\end{array}$ \\
\hline CATA3_ARATH (At1g20620) & Catalasa (Ratón) & Ghosh et al., 2006 \\
\hline PGKH_ARATH (At1g56190) & 3-fosfoglicerato kinasa (Levadura; Humano) & $\begin{array}{l}\text { Bacharach et al., } 1977 \\
\text { Guesquière et al., } 2009\end{array}$ \\
\hline ACA9_ARATH (At3g21180) & Ca-ATPasa (Rata) & Knyushko et al., 2005 \\
\hline HDA5_ARATH (At5g61060) & $\begin{array}{l}\text { Histona deacetilase HDAC2 (células de } \\
\text { mamífero) }\end{array}$ & Ito et al., 2004 \\
\hline ACT7_ARATH (At5g09810) & Actinas (células de mamífero; Ratón) & Casoni et al., 2005; Zhang et \\
\hline \multicolumn{3}{|l|}{ ACT2_ARATH (At3g18780) } \\
\hline TBA6_ARATH (At4g14960) & Tubulinas (Cerdo; Humano; células de mamífero; & Fiore et al., 2006; Zhang et \\
\hline TBA3_ARATH (At5g19770) & Ratón) & al., 2007 \\
\hline \multicolumn{3}{|l|}{ TBB4_ARATH (At5g44340) } \\
\hline \multicolumn{3}{|l|}{ TBB2_ARATH (At5g62690) } \\
\hline \multicolumn{3}{|l|}{ TBB1_ARATH (At1g75780) } \\
\hline GLNA2_ARATH (At5g35630) & Glutamina sintasa (Rata; Ratón) & $\begin{array}{l}\text { Görg et al., 2006; Zhang et } \\
\text { al., } 2007\end{array}$ \\
\hline TYW23_ARATH (At4g04670) & t-RNA sintetasas (Humano) & Guesquière et al., 2009 \\
\hline \multicolumn{3}{|l|}{ SYV_ARATH (At1g67220) } \\
\hline \multicolumn{3}{|l|}{ SYM_ARATH (At4g13780) } \\
\hline HSP83_ARATH (At5g56010) & $\begin{array}{l}\text { Proteína de choque térmico } 90 \text { (células de } \\
\text { mamífero, Ratón) }\end{array}$ & Zhang et al., 2007 \\
\hline HSP71_ARATH (At5g02500) & Proteína de choque térmico 71-kDa (Ratón) & Casoni et al., 2005; Zhang et \\
\hline HSP73 ARATH (At3g09440) & & al., 2007 \\
\hline AAT5_ARATH (At4g31990) & Aspartato aminotransferasa (Vaca; Ratón) & $\begin{array}{l}\text { DiCola et al., 1976; Zhang et } \\
\text { al., } 2007\end{array}$ \\
\hline \multirow{3}{*}{$\begin{array}{l}\text { MDHP_ARATH (At3g47520) } \\
\text { MDHG1_ARATH (At5g09660) }\end{array}$} & Malato:NADP+ oxidoreductasas (Paloma; Ratón, & Chang et al., 1980; Zhang et \\
\hline & Humano) & al., 2007 \\
\hline & & Guesquière et al., 2009 \\
\hline RH56_ARATH (At5g11200) & RNA helicasa ATP-dependiente (Humano) & Guesquière et al., 2009 \\
\hline FBX10_ARATH (At1g51290) & Proteínas F-Box (Humano) & Guesquière et al., 2009 \\
\hline \multicolumn{3}{|l|}{ FBK84_ARATH (At4g19865) } \\
\hline \multicolumn{3}{|l|}{ FBK19_ARATH (At1g32430) } \\
\hline EF1A_ARTH (At1g07940) & Factor de Elongación 1-alfa (Humano) & Guesquière et al., 2009 \\
\hline PGMP_ARATH (At5g51820) & Fosfoglucomutasa (Conejo) & Layne et al., 1979 \\
\hline 2AAA_ARATH (At1g25490) & Ser/Thr-protein fosfatasa (Humano) & Guesquière et al., 2009 \\
\hline IF5A2_ARATH (At1g26630) & $\begin{array}{l}\text { Factor de inicación de la traducción eucariótico } \\
\text { (Humano) }\end{array}$ & Guesquière et al., 2009 \\
\hline PGKH_ARATH (At1g56190) & PGK1 (Ratón) & Zhang et al., 2007 \\
\hline WBC16_ARATH (At3g55090) & Transportador ABC (Humano) & Guesquière et al., 2009 \\
\hline \multirow[t]{2}{*}{ GBLP_ĀRATH (At1g18080) } & Proteína beta de unión a guanina (Humano; & Guesquière et al., 2009 \\
\hline & Ratón) & Zhang et al., 2007 \\
\hline DRP1D_ARATH (At2g44590) & Dinamina (Ratón) & Zhang et al., 2007 \\
\hline SCP37_ARATH (At3g52010) & Carboxipeptidasa (Vaca) & Zisapel 1978 \\
\hline
\end{tabular}


Figura S2. Los potenciales sitios de nitración de GAPDH, Serina Hidroximetiltransferasa, Transcetolasa, Rubisco (subunidad grande) y Rubisco activasa están conservados en plantas y otros organismos.

En amarillo se muestra el péptido identificado como nitrado por MALDI-TOF y en negrita las Y conservadas dentro de ese péptido.

Gliceraldehido-3-fosfato deshidrogenasa

Arabidopsis Nicotiana Oryza Rattus Mus Homo Escherichia saccharomyces
DAKAGIALSDKFVKLVSWYDNEWGYSSRVVDLIVHMSKA- 338 DAKAGIALSKNFVKLVSWȲDNEWGȲSSRVIDLICHMASVA 326 DAKAGIALNDNFVKLVAW $\underline{\underline{Y}}$ DNEWGY్ SNRVIDLIRHMAKTQ 337 DAGAGIALNDNFVKLISWY'DNEYGȲSNRVVDLMAYMASKE 333 DAGAGIALNDNFVKLISWȲ DNEYGȲ SNRVVDLMAYMASKE 333 DAGAGIALNDHFVKLISW $\underline{\underline{Y}}$ DNEFGȲ SNRVVDLMAHMASKE 335 DAKAGIALNDNFVKLVSWY'DNETGȲSNKVLDLIAHISK-- 331 DASAGIQLSPKFVKLVSW $\underline{\underline{Y}}$ DNEYG $\underline{\underline{Y}}$ STRVVDLVEHIAKA- 332

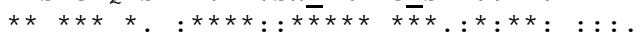

Serina Hidroximetiltransferasa

Arabidopsis

Oryza

Rattus

Mus

Homo

Nicotiana

Saccharomyces

Escherichia

Transketolasa

Arabidopsis

Nicotiana

Oryza

Saccharomyces

Escherichia

Rattus

Mus

Homo

TSGGKKISATSIYFESLPYKVNFTTGYIDY IKLEEKALDFRPKLLICGGSAYPRDWDYAR 200 TAGGKKISATSIYFESLPYKVSAATGȲ IDY TDK-KKISATSIFFESMPYKVYPDTGȲINȲDOLEENASLFHPKLIIAGTSCYSRNLDYAR 410 TDK-KKISATSIFFESMPYKVYPETGȲINȲDQLEENASLFHPKLIIAGTSCYSRNLDYAR 207 TDK-KKISATSIFFESMPYKVNPDTGȲINȲDQLEENARLFHPKLIIAGTSCYSRNLEYAR 213 TDT-KKISAVSIFFETMPYRLNESTGȲIDȲDQLEKSATLFRPKLIVAGASAYARLYDYAR 243 TEN-RKISAVSTYFESFPYRVNPETGIIDȲDTLEKNAILYRPKVLVAGTSAYCRLIDYKR 204 ----SPVNFSGKLYNIVPYGID-ATGHIDȲADLEKQAKEHKPKMIIGGFSAYSGVVDWAK 185

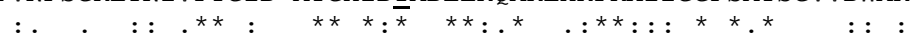

VKNGNTGYDEIRAAIKEAKTVTDKPTLIKVTTTIGYGSPNKANSYSVHGAALGEKEVEAT 352 VKNGNTGYDEIRAAIKEAKTVTDKPTMIKVTTTIGFGSPNKANSY'SVHGSALGAKEVEAT 355 VKNGNDGYDEIRAAIKEAKAVTDKPTLIKVTTTIGFGSPNKANSY్ SVHGSALGTKEVEAT 355 VDKGDDDMESISSALEKAKLSKDKPTIIKVTTTIGFGSLQQG-TĀGVHGSALKADDVKOL 275 EIDG-HDPQAVKEAILEAQSVKDKPSLIICRTVIGFGSPNKAGKEEAHGAPLGEEEVALA 272 VDGH-----SVEELCKAFGQAKHQPTAIIAKTFKGRGITGIEDKEAWHGKPLPKN----- 297 VDGH-----SVEELCKAFGQAKHQPTAIIAKTFKGRGITGIEDKEAWHGKPLPKN----- 265 VDGH-----SVEELCKAFGQAKHQPTAIIAKTFKGRGITGVEDKESWHGKPLPKN----- 265

$$
\text { : ..: }{ }^{*} \text { * } * \text { * } * \text {. } * \text { * . }
$$

Rubisco (subunidad grande)

Clamidomonas Micromonas Arabidopsis Oryza Nicotiana Espinaca Nostoc

Clamidomonas Micromonas Arabidopsis Oryza Nicotiana Espinaca Nostoc

Rubisco activase

Clamidomonas Micromonas Arabidopsis Espinaca Nicotiana Oryza Nostoc
LSAKNYGRAVYECLRGGLDFTKDDENVNSQPFMRWRDRFLFVAEAIYKAQAETGEVKGHY 239 LSAKNYGRAVYECLRGGLDFTKDDENVNSQPFMRWRDRFLFVAEAIYKAQAETGEIKGHY $\bar{Y} 177$ LSAKNYGRAVYECLRGGLDFTKDDENVNSQPFMRWRDRFLFCAEAIYKSQAETGEIKGHY 239 LSAKNYGRACYECLRGGLDFTKDDENVNSQPFMRWRDRFVFCAEAIYKSQAETGEIKGH $\underline{\underline{Y}} 239$ LSAKNYGRAVYECLRGGLDFTKDDENVNSQPFMRWRDRFLFCAEALYKAQAETGEIKGHȲ 239 LSAKNYGRAVYECLRGGLDFTKDDENVNSQPFMRWRDRFLFCAEALYKAQAETGEIKGHȲ 239 LSAKNYGRAVYECLRGGLDFTKDDENINSAPFQRWRDRFLFVADAITKAQAETGEIKGH $\bar{Y} \quad 240$

LNATAGTCEEMMKRAVCAKELGVPIIMHDYLTGGFTANTSLAIYCRDNGLLLHIHRAMHA 299 LNVTAATSEEMIKRTVCAKELGLPIVMHDYITGGFTSNTSLSLYCRDHGLLLHIHRAMHA 237 LNATAGTCEEMIKRAVFARELGVPIVMHDYLTGGFTANTSLSHYCRDNGLLLHIHRAMHA 299 LNATAGTCEEMIKRAVFARELGVPIVMHDYLTGGFTANTSLAHYCRDNGLLLHIHRAMHA 299 LNATAGTCEEMIKRAVFARELGVPIVMHDYLTGGFTANTSLAHYCRDNGLLLHIHRAMHA 299 LNATAGTCEDMMKRAVFARELGVPIVMHDYLTGGFTANTTLSHYCRDNGLLLHIHRAMHA 299 LNVTAPTCEEMLKRAEYAKELKOPI IMHDYLTAGFTANNTLARWCRDNGLLLHIHRAMHA 300

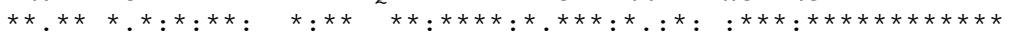

ARVYDDMVRQWITDTGVDKIGQQLVNAR--QKVAMPKVSMDLNVLIKYGKSLVDEQENVK 380 ARVȲDDKVREWIRETGIEAMGPLLVNPKRGSKVTFEPPRMSLDILLQYGKALEMEQENVK 384 ARVȲDDEVRKFVESLGVEKIGKRLVNSRE-GPPVFEQPEMTYEKLMEYGNMLVMEQENVK 408 ARVȲDDEVRKWVNSVGVDNVGKKLVNSKD-GPPVFEQPEMTLQKLMEYGNMLVQEQENVK 406 ARVȲDDEVRKWVSGTGIEKIGDKLLNSFD-GPPTFEQPKMTIEKLLEYGNMLVQEQENVK 412 ARVȲDDEVRKWVSDTGVENIGKRLVNSRE-GPPEFEQPKMTIEKLMEYGYMLVKEQENVK 399 SRIY $D I Q I R D F I H K V G F E R I S L R V V N S L E-A P P E F K K P D F S L A H L I E S G N L V L G E Q Q R V D 281$

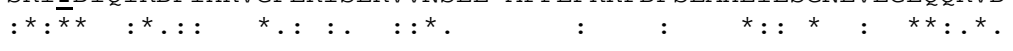


Figura S3. Análisis del grado de conservación y de la estructura de las Metionina Sintasas.

A. Alineamiento de la secuencia de aminoácidos de diferentes Metioninas Sintasas. En amarillo se resalta el péptido nitrado identificado y en negrita sombreado de gris la Y nitrada. B. Estructura de AtMS1 donde se indica la posición de la tirosina nitrada, Y287, formando puentes de hidrógeno con T262 y F264. Se indica en verde la molécula de ácido (2S)-2-[[4-[(2-amino-4-ceto-1H-pteridin-6-il)metilamino]benzoil]amino]glutárico (THG), en amarillo la hidroxocobalamina (HC) y en naranja el Zinc (Zn).

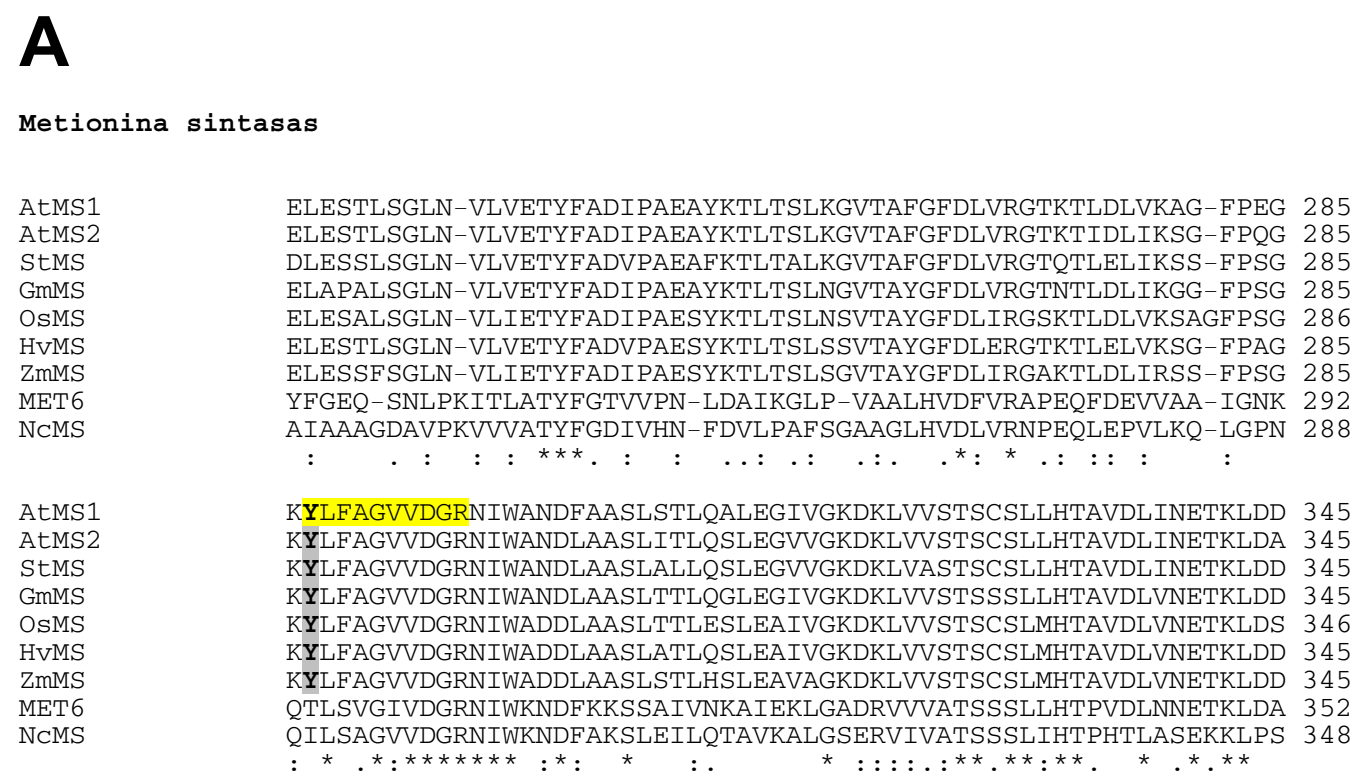

B

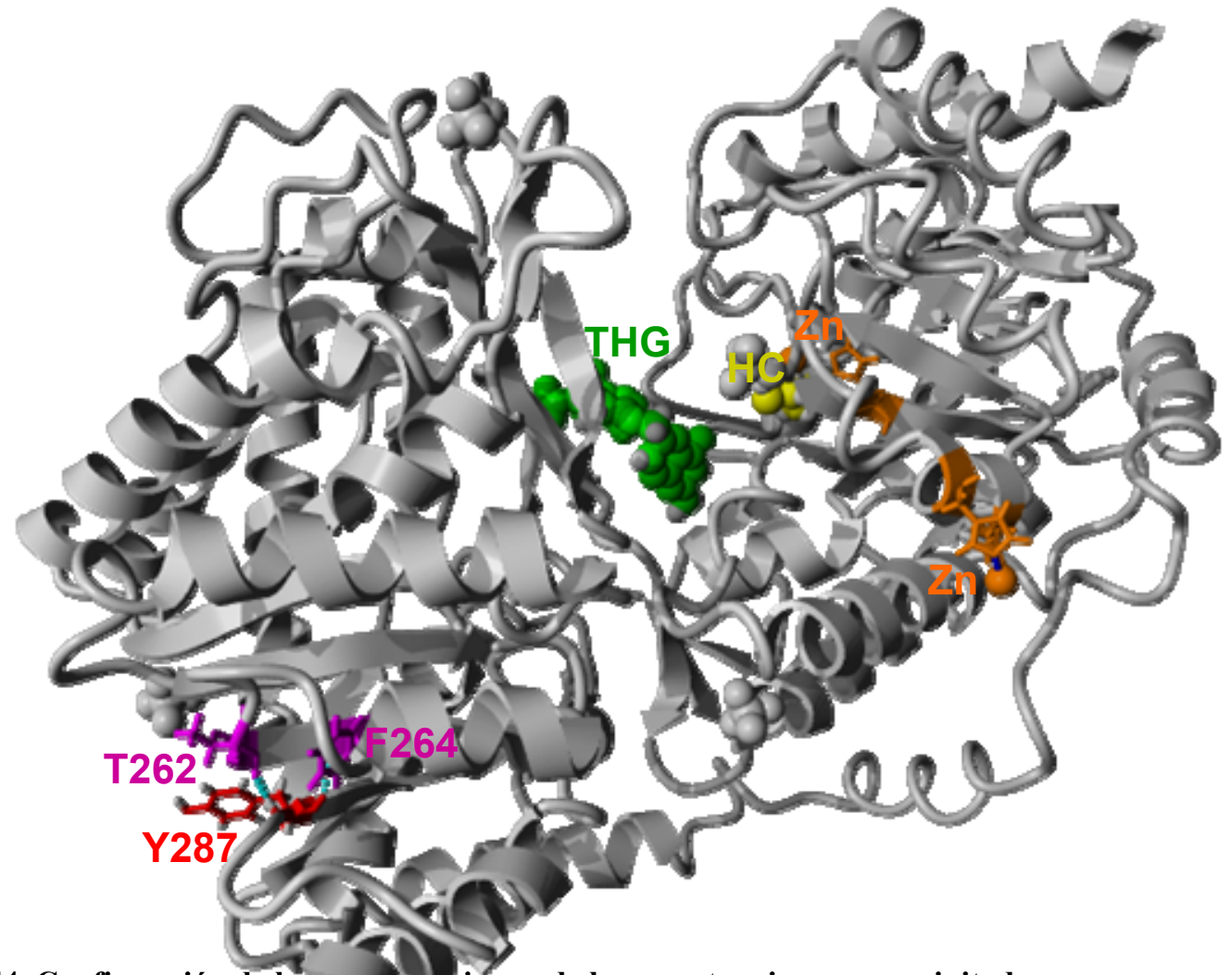

Figura S4. Confirmación de las iu

Se muestran las imágenes de los geles completos correspondientes a la Figura 37. 

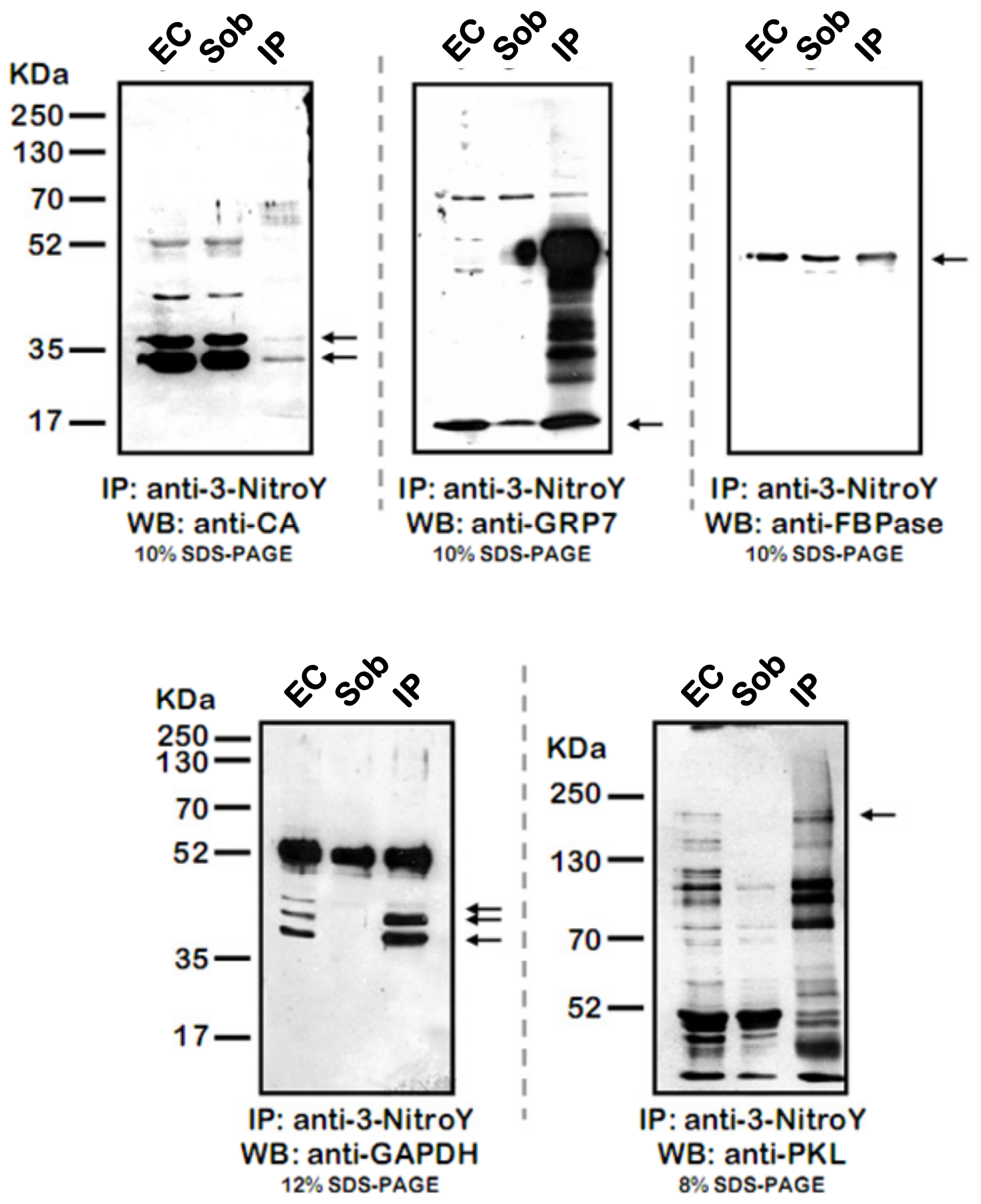
CONCLUSIONES 


\section{Conclusiones}

1. Mediante el análisis de los niveles de NO en mutantes afectados en su biosíntesis hemos identificado la ruta dependiente de la actividad NR y de la proteína AtNOA1 como las principales vías de síntesis de NO en Arabidopsis.

2. La hipersensibilidad al ABA de mutantes deficientes en la producción de $\mathrm{NO}$ en procesos como la dormición, la germinación, el establecimiento de plántula y el cierre estomático nos permite proponer un papel negativo del $\mathrm{NO}$ en la señalización de ABA.

3. Tras analizar los mutantes afectados en la síntesis de NO en condiciones de oscuridad y luz, hemos descrito el mecanismo molecular por el que el NO regula postivamente la fotomorfogénesis. Este mecanismo actúa a dos niveles: por un lado, el NO regula negativamente la expresión de genes $P I F, \mathrm{y}$, por otro, modula positivamente la acumulación de proteínas DELLA mediante la regulación transcripcional de SLY1. Además, hemos comprobado que las giberelinas regulan negativamente los niveles de NO asegurando así un fenotipo etiolado en oscuridad.

4. El uso de anticuerpos que detectan la nitración de tirosinas junto a dos aproximaciones proteómicas diferentes y complementarias nos han permitido describir el conjunto más extenso, hasta la fecha, de proteínas potencialmente nitradas in vivo en Arabidopsis. Además, mediante la identificación del sitio inequívoco de nitración en una de estas proteínas, la Metionina Sintasa 1, y del impacto de la nitración en la actividad de la proteína GAPDH hemos comprobado que el método es válido para la identificación de proteínas nitradas, y que este tipo de modificación post-traduccional tiene, al igual que en modelos animales, un impacto sobre la función de las proteínas 


\section{Material biológico y condiciones de cultivo.}

\subsection{Plantas: Arabidopsis thaliana.}

Se utilizó como sistema experimental la planta modelo Arabidopsis thaliana por su utilidad para el análisis genético y molecular. Los ecotipos silvestres empleados fueron Columbia-0 (Col0) y Landsberg erecta (Ler) (Nottingham Arabidopsis Stock Center). Además de los mutantes y líneas transgénicas generadas en este trabajo se utilizaron los siguientes mutantes y/o líneas transgénicas cedidas por diferentes laboratorios: pRGA::GFP-RGA, sly1-10, sly-1D, gal-3 (TaiPing Sun, fondo Ler); 35S::TAP-RGL1, 35S::TAP-RGL2, 35S::TAP-RGL3, 35S::TAP-RGA, 35S::TAP-GAI, 35S::TAP-GAIA17, 35S::TAP-RGAA17, 5della (Xing-Wang Deng, fondo Ler); 35S::TAP-GFP (Vicente Rubio, fondo Col-0); phyA, phyB (NASC, fondo Col-0), 4della (NASC, fondo Ler); noal-1, (Nigel Crawford, fondo Col-0); pif3-3, pif4-2, pif1-1pif3-3pif4-2pif5-3 (pifQ) (Peter Quail, fondo Col-0); gidla,b, gidla,c, gidlb,c (Steve Thomas, fondo Col-0); PIF3OX (Giltsu Choi, fondo Col-0); PIF4OX (Christian Fankhauser, fondo Col-0); pRGA::GFP-RGA/gal3 (David Alabadí, fondo Ler).

El cultivo in vitro de Arabidopsis se llevó a cabo en placas Petri con 4,4 gr/L de medio MS estéril (Murashige y Skoog, 1962) suplementado con $10 \mathrm{gr} / \mathrm{L}$ de sacarosa y con pH 5,7 ajustado previamente a la adición del agar $(8 \mathrm{gr} / \mathrm{L})$. En el caso de cultivo in vitro en medio líquido, se utilizaron placas de 6 y 24 pocillos (Costar) conteniendo $1 \mathrm{~mL}$ de medio MS estéril (4,4 gr/L) suplementado con $5 \mathrm{gr} / \mathrm{L}$ sacarosa. En cada pocillo se colocaron alrededor de 12 semillas refrescando el medio al octavo día. Finalmente, los tratamientos se realizaron tres días después, cuando las plántulas tenían 11 días.

Para cultivar las plantas in vitro las semillas fueron esterilizadas con hipoclorito sódico al 30 $\%(\mathrm{v} / \mathrm{v})$ y el surfactante Tween-20 al 0,02 \% (v/v), manteniendo agitación constante durante 10 min. y realizando a continuación cinco lavados con agua miliQ estéril. Alternativamente, las semillas se esterilizaron mediante la exposición a cloro gaseoso derivado de una solución de hipoclorito sódico y ácido clorhídrico, durante 4 horas. Con el fin de favorecer y sincronizar la germinación, las semillas se estratificaron al menos 3 días a $4{ }^{\circ} \mathrm{C}$ antes de cultivarlas in vitro con un fotoperiodo de 16 horas de luz y 8 horas de oscuridad (día largo, DL) y $21-23{ }^{\circ} \mathrm{C}$ de temperatura. Para los experimentos en las diferentes calidades de luz, las semillas se mantuvieron, tras la estratificación, alrededor de $6 \mathrm{~h}$ en luz blanca $\left(\approx 70 \mu \mathrm{mol} \mathrm{m} \mathrm{m}^{-2} \mathrm{~s}^{-1}\right)$, seguido por $18 \mathrm{~h} \mathrm{de}$ oscuridad, antes de pasar las placas a la calidad de luz pertinente. Las intensidades de las diferentes calidades de luz fueron de $16 \mu \mathrm{mol} \mathrm{m} \mathrm{m}^{-2}$ para la luz azul, $5 \mu \mathrm{mol} \mathrm{m} \mathrm{m}^{-2} \mathrm{~s}^{-1}$ para la luz roja lejana y 
$20 \mu \mathrm{mol} \mathrm{m} \mathrm{m}^{-2} \mathrm{~s}^{-1}$ para la luz roja, a no ser que se indique lo contrario. Las diferentes calidades de luz se consiguieron mediante LEDs (Percival Sci., USA).

El cultivo en tierra tanto de semillas, estratificadas previamente, como de plántulas se realizó sobre un sustrato Jiffy-7 (grupo Jiffy) y se llevó a cabo en cámaras con un fotoperiodo de DL o con un fotoperiodo de 8 horas de luz y 16 horas de oscuridad (día corto, DC). En todos los casos las plantas se iluminaron con luz blanca suministrada por tubos fluorescentes con una intensidad de $150 \mu \mathrm{E} \mathrm{m}^{-2} \mathrm{~s}^{-1}$ y la temperatura osciló entre 20 y $22{ }^{\circ} \mathrm{C}$ a lo largo del día manteniendo una humedad relativa en torno al $60 \%$.

\subsubsection{Mutantes generados en este trabajo.}

Con el objetivo de conseguir plantas con los niveles de óxido nítrico reducidos, se aislaron mutantes de las posibles vías de síntesis varP (iNOS)-dependiente, AtNOA1-dependiente, NRdependiente y XOR-dependiente. Todas las líneas utilizadas se obtuvieron del banco de semillas de Nottingham (NASC). Todos los mutantes, se encuentran en el fondo Col-0.

En el caso de mutantes sencillos, las semillas procedentes del banco de semillas (mezcla de $\mathrm{T}_{2} \mathrm{y} \mathrm{T}_{3}$ ), se cultivaron en tierra y se analizaron un mínimo de 24 plantas para buscar mutantes homocigotos para la inserción de T-DNA mediante PCR con oligonucleótidos específicos. La secuencia de los oligonucleótidos utilizados se encuentra descrita en la Tabla M2 (página 137). En el caso de encontrar mutantes en homocigosis, se comprobó el nivel de transcrito para el gen mutado, en cada uno de los casos, mediante RT-PCR semicuantitativa.

Para la obtención del doble mutante xor1xor2, se cruzaron plantas xor1-1 con plantas xor2-1. Las semillas obtenidas de los cruces se sembraron en tierra y se comprobó mediante PCR que ambas mutaciones se encontraban en heterocigosis. Las semillas de estas plantas se recogieron por separado y se sembró un número de plantas $\mathrm{F}_{3}$ elevado (100 plantas) que nos permitiera tener la probabilidad de encontrar al menos una planta doble mutante. Como las plantas no presentaron fenotipo, se procedió al análisis por PCR de toda la población. No se encontraron plantas homocigotas para las dos mutaciones así que se recogieron semillas de una planta homocigota para la mutación en XOR1 y heterocigota para la mutación en XOR2. Al analizar por PCR la descendencia ( $>50$ individuos) de esta planta, se encontró una planta doble mutante xor1xor 2 . A continuación se confirmó en la descendencia el nivel de transcrito de XOR1 y XOR2 mediante RTPCR semicuantitativa. 


\begin{tabular}{|c|c|c|c|c|c|c|c|}
\hline Nombre & Mutante & Gen mutado & Fondo & Tipo & Num. Stock & Donante & Referencia \\
\hline varP1-1 & Sencillo & At3g33010 & Col-0 & T-DNA & N610091 & SALK_110091 & Este trabajo \\
\hline noa1-1 & Sencillo & At $4 \mathrm{~g} 47450$ & Col-0 & T-DNA & & Nigel Crawford & 1 \\
\hline noa1-2 & Sencillo & At $4 \mathrm{~g} 47450$ & Col-0 & T-DNA & N821383 & SAIL_507_E11 & Este trabajo \\
\hline nia1nia2 & Doble & $\begin{array}{l}\text { At1g77760 } \\
\text { At1g37130 }\end{array}$ & Col-0 & $\begin{array}{l}\text { Puntual (NIA1) } \\
\text { Deleción (NIA2) }\end{array}$ & N2356 & G4-3 & 2 \\
\hline nia1,2noa1-2 & Triple & $\begin{array}{l}\text { At4g47450 } \\
\text { At } 1 \mathrm{~g} 77760 \\
\text { At1g37130 }\end{array}$ & Col-0 & $\begin{array}{c}\text { T-DNA (AtNOA1) } \\
\text { Puntual (NIA1) } \\
\text { Deleción (NIA2) }\end{array}$ & & & Este trabajo \\
\hline$n r 1-1$ & Sencillo & At1g77760 & Col-0 & T-DNA & N571547 & SALK_071547 & Este trabajo \\
\hline$n r 1-2$ & Sencillo & At1g77760 & Col-0 & T-DNA & N504181 & SALK_004181 & Este trabajo \\
\hline$n r 2-1$ & Sencillo & At1g37130 & Col-0 & T-DNA & N588070 & SALK_088070 & Este trabajo \\
\hline xor1-1 & Sencillo & At4g34890 & Col-0 & T-DNA & N648364 & SALK_148364 & Este trabajo \\
\hline xor2-1 & Sencillo & At4g34900 & Col-0 & T-DNA & N832099 & SAIL_722_C03 & Este trabajo \\
\hline xor1xor2 & Doble & $\begin{array}{l}\text { At } 4 g 34890 \\
\text { At } 4 g 34900\end{array}$ & $\begin{array}{l}\text { Col-0 } \\
\text { Col-0 }\end{array}$ & $\begin{array}{l}\text { T-DNA (XOR1) } \\
\text { T-DNA (XOR2) }\end{array}$ & & & Este trabajo \\
\hline nia1,2noa1-2 pRGA::GFP-RGA & Cuadruple & $\begin{array}{l}\text { At4g47450 } \\
\text { At1g77760 } \\
\text { At1g37130 } \\
\text { At2g01570 }\end{array}$ & Ler/Col-0 & $\begin{array}{c}\text { T-DNA (AtNOA1) } \\
\text { Puntual (NIA1) } \\
\text { Deleción (NIA2) } \\
\text { Transgenica Kan }^{\mathrm{R}}\end{array}$ & & Tai-Ping Sun & Este trabajo \\
\hline 35S::TAP-DELLAs & & $\begin{array}{l}\text { At1g14920 } \\
\text { At2g01570 } \\
\text { At1g66350 } \\
\text { At3g03450 } \\
\text { At5g17490 }\end{array}$ & Ler & Transgénica Gent ${ }^{R}$ & & Xing-Wang Deng & 3 \\
\hline rga-24gai-t6 & Doble & $\begin{array}{l}\text { At2g01570 } \\
\text { At1g14920 }\end{array}$ & & $\begin{array}{l}\text { Deleción (rga-24) } \\
\text { Trasposón (gai-t6) }\end{array}$ & & Nicholas Harberd & \\
\hline 5della & Quintuple & $\begin{array}{l}\text { At1g14920 } \\
\text { At2g01570 } \\
\text { At1g66350 } \\
\text { At3g03450 } \\
\text { At5g17490 }\end{array}$ & Ler & $\begin{array}{l}\text { Trasposón (gai-t6) } \\
\text { Trasposón (rga-t2) } \\
\text { Trasposón (rgl1-1) } \\
\text { Trasposón (rgl2-1) } \\
\text { T-DNA (rgl3-1) }\end{array}$ & N16298 & Xing-Wang Deng & 3 \\
\hline$p R G A:: G F P-R G A$ & & At2g01570 & Ler & Transgenica $\mathrm{Kan}^{\mathrm{R}}$ & & Tai-Ping Sun & 4 \\
\hline sly1-10 & Sencillo & At4g24210 & Ler & Deleción-Inserción & 3510701891 & Tai-Ping Sun & 5 \\
\hline$s / y-1 D$ & Sencillo & At4g24210 & Ler & Sustitución en C-t & 3510701907 & Tai-Ping Sun & 6 \\
\hline pif3-3 & Sencillo & At1g09530 & Col-0 & T-DNA & & Peter Quail & 7 \\
\hline pif4-2 & Sencillo & At2g43010 & Col-0 & T-DNA & & Peter Quail & 7 \\
\hline pifQ & Cuadruple & $\begin{array}{l}\text { At2g20180 } \\
\text { At1g09530 } \\
\text { At2g43010 } \\
\text { At3g59060 }\end{array}$ & Col-0 & $\begin{array}{l}\text { T-DNA (pif1-1) } \\
\text { neutrones (pif3-3) } \\
\text { T-DNA (pif4-2) } \\
\text { T-DNA (pif5-1) }\end{array}$ & N66049 & Peter Quail & 7 \\
\hline 35S::TAP-GFP & & & Col-0 & & & Vicente Rubio & \\
\hline gid1a,b & Doble & $\begin{array}{l}\text { At3g05120 } \\
\text { At3g63010 }\end{array}$ & Col-0 & $\begin{array}{l}\text { T-DNA } \\
\text { Transposón }\end{array}$ & & Steve Thomas & 8 \\
\hline gid1a,c & Doble & $\begin{array}{l}\text { At3g05120 } \\
\text { At5g27320 }\end{array}$ & Col- 0 & $\begin{array}{l}\text { T-DNA } \\
\text { T-DNA }\end{array}$ & & Steve Thomas & 8 \\
\hline gid $1 b, c$ & Doble & $\begin{array}{l}\text { At3g63010 } \\
\text { At5g27320 }\end{array}$ & Col-0 & $\begin{array}{l}\text { Transposón } \\
\text { T-DNA }\end{array}$ & & Steve Thomas & 8 \\
\hline PIF3OX & & At1g09530 & Col-0 & & & Giltsu Choi & 9 \\
\hline PIF4OX & & At2g43010 & Col-0 & & & Christian Fankhauser & 10 \\
\hline ga1-3 & Sencillo & At4g02780 & Ler & Deleción & CS3104 & Tai-Ping Sun & 11 \\
\hline ga1-3 pRGA::GFP-RGA & Doble & $\begin{array}{l}\text { At } 4 \mathrm{~g} 02780 \\
\text { At2g01570 }\end{array}$ & Ler & $\begin{array}{c}\text { Deleción } \\
\text { Transgenica Kan }\end{array}$ & & David Alabadí & 12 \\
\hline
\end{tabular}

1 Guo et al, 2003

2 Wilkinson and Crawford, 1993

3 Feng et al., 2008

4 Silverstone et al., 1998

5 McGinnis et al., 2003

6 Dill et al., 2004

7 Leivar et al., 2008

8 Griffiths et al., 2006

9 Shin et al., 2007

Lorrain et al., 2008

11 Silverstone et al., 1997

12 Stavang et al., 2009 
Para la obtención del triple mutante nia1nia2noal-2, flores emasculadas de plantas nialnia2 se fecundaron con polen procedente de plantas noal-2. Para poder genotipar la población segregante se diseñaron oligonucleótidos específicos para cada mutación. Así, la mutación puntual en NIA1/NR1 (Wilkinson y Crawford, 1993), se detectó mediante la aplicación de la técnica CAPS (Cleaved Amplified Polimorphic Sequences), donde, oligonucleótidos que flanquean la mutación se utilizan para amplificar la región mutada y mediante la digestión de ese amplicón con un enzima de restricción podemos discriminar entre alelos silvestres (hay corte) y alelos mutados (no hay corte) al separar el producto de digestión por electroforesis en geles de agarosa. Para detectar la mutación en NIA2/NR2 (Wilkinson y Crawford, 1993) se utilizaron oligonucleótidos que anillan en la región delecionada en NIA2/NR2 en el mutante nia2. Para detectar la presencia del T-DNA que incorpora el mutante noal-2 se utilizaron los mismos oligonucleótidos específicos de ese gen y los de la región flanqueante del T-DNA que se utilizaron para genotipar el mutante sencillo noal-2. Tras comprobar que todas las mutaciones se encontraban en heterocigosis en la $F_{1}$, se recogieron las semillas y se sembraron un gran número de ellas para buscar el triple mutante. Tras analizar más de 300 plantas, se encontró un individuo triple mutante y se procedió a analizar el nivel de transcrito de cada uno de los genes mutados mediante RT-PCR semicuantitativa.

Para la obtención de plantas que portaran la línea $p R G A:: G F P-R G A$ en el fondo genético nialnia2noal-2, se cruzaron plantas homocigotas para cada fondo genético. Tras comprobar en la primera generación que todas las mutaciones estaban en heterocigosis se procedió a la selección de las mutaciones nial, nia2, y noal-2, tal y como se ha descrito anteriormente. La presencia de la construcción $p R G A:: G F P-R G A$ se determinó mediante la germinación de las semillas en medio suplementado con Kanamicina. En la tercera generación se identificaron plantas homocigotas $p R G A: \because G F P-R G A /$ nialnia2noa1-2 y sus semilla fueron utilizadas en los experimentos que así lo indican.

\subsection{Bacterias.}

\subsubsection{Escherichia coli.}

Para la propagación y purificación de plásmidos se utilizó la cepa $E$. coli DH5a cultivada en medio Luria-Bertani (LB) (sales LB 20 gr/L) estéril tanto en medio líquido como en medio sólido, suplementado con agar (15 gr/L). Para la selección de bacterias transformadas con el plásmido de interés se añadió al medio el antibiótico correspondiente según el caso, concretamente, kanamicina $(100 \mathrm{mg} / \mathrm{L})$. 
Para la obtención de proteínas recombinantes se utilizaron células competentes comerciales de la cepa BL21(DE3) (Sigma-Aldrich)

\section{Tratamientos aplicados a las plantas.}

Para llevar a cabo este trabajo, las plantas de A. thaliana fueron sometidas a diferentes factores de estrés y a distintos tratamientos exógenos con compuestos químicos como se detalla a continuación. Las muestras, se recogieron a los tiempos o concentraciones indicadas en cada experimento, congelándolas en $\mathrm{N}_{2}$ líquido y siendo almacenadas a $-80{ }^{\circ} \mathrm{C}$ hasta su posterior análisis, excepto en los casos en que se indica otro tipo de análisis de las muestras.

\subsection{Aplicación exógena de SA, GA, ABA, PAC y SNP.}

Las aplicaciones exógenas de SA (Merck), ABA (Sigma-Aldrich), PAC (Duchefa) ó $\mathrm{GA}_{3}$ (Duchefa) fueron realizadas bien por pulverización en las plantas cultivadas en tierra o cultivadas in vitro hasta la completa humidificación de las hojas o mediante la adición del compuesto correspondiente al medio MS utilizado para el crecimiento de las plántulas in vitro. En plántulas cultivadas in vitro en medio líquido, los distintos compuestos se añadieron al medio MS líquido. Concretamente, se sustituyó el medio de cultivo por medio fresco con la concentración del compuesto químico correspondiente cuando las plántulas tenían 11 días.

Para la aplicación exógena de nitroprusiato sódico (SNP) se siguió siempre el esquema descrito por Bethke et al (2006) con pequeñas modificaciones, de forma que el SNP no entra en contacto con las plantas, sino que es el óxido nítrico liberado en la descomposición de éste el que realiza el efecto.

\subsection{Deshidratación.}

Los experimentos de deshidratación se llevaron a cabo con plantas adultas crecidas en condiciones de DC. Se realizaron dos variantes diferentes para establecer el grado de tolerancia de los diferentes mutantes a la sequía: Por un lado se pesaron plantas enteras de tamaño similar crecidas en las mismas condiciones de irrigación envolviendo las macetas en parafilm para minimizar la pérdida de agua por evaporación. Tras cesar el riego, las plantas se pesaron cada 7 días hasta el día 28, estimando la pérdida de peso como la pérdida de agua con el tiempo. En este punto las plantas se volvieron a regar y se estimo el porcentaje de supervivencia como el número de plantas que continuaron con su crecimiento produciendo nuevas hojas. Por otro lado, plantas crecidas en las mismas condiciones de irrigación se dejaron de regar y, tras 12 o 14 días, se tomaron hojas de las plantas haciendo 3 grupos de 3 hojas cada grupo. Se limpiaron de posibles 
restos de tierra y se pesaron. Inmediatamente, se sumergieron en agua destilada. Tras 3 horas, las hojas se secaron cuidadosamente y se volvieron a pesar de forma que el incremento en peso equivale a la pérdida de agua que han sufrido esas hojas en el periodo de deshidratación. Ambos experimentos se adaptaron de Sáez et al (2006).

\subsubsection{Apertura estomática, conductancia estomática y medidas psicrométricas.}

Se analizaron otros parámetros fisiológicos de las plantas para establecer su resistencia a la deshidratación.

Para la medida de la apertura estomática, se capturaron imágenes de las mismas regiones del envés de las primeras hojas verdaderas de cuatro plántulas diferentes mediante el microscopio confocal Leica TCS SL. La anchura y longitud de diferentes estomas se midieron mediante el análisis de las imágenes con el programa ImageJ (National Institutes of Health). Antes de tomar las imágenes, las plántulas crecidas durante 10 días bajo condiciones de DL se incubaron en una solución de apertura de estomas $(30 \mathrm{mM} \mathrm{KCl}, 10 \mathrm{mM}$ MES-KOH, $\mathrm{pH}=6.1)$ en placas de 24 pocillos (Costar) durante $2.5 \mathrm{~h}$ bajo iluminación con tubos fluorescentes $\left(150-200 \mu \mathrm{E} \mathrm{m}^{-2} \mathrm{~s}^{-1}\right)$ a 22 ${ }^{\circ} \mathrm{C}$. Para inducir el cierre estomático, las plántulas fueron incubadas en las concentraciones de ABA indicadas en cada caso durante $2.5 \mathrm{~h}$. Para los ensayos de la inhibición de la apertura estomática, los diferentes compuestos, fueron aplicados bajo iluminación con luz verde para evitar la apertura de los estomas por luz.

La conductancia estomática de las hojas de los diferentes mutantes se llevó a cabo en plantas crecidas en DC mediante un porómetro Steady State Difussion Porometer SC-1 (Decagon Devices) tal y como indican los fabricantes. Las medidas se realizaron 0, 7 y 14 días tras dejar de regar en el envés de tres hojas de seis plantas diferentes para cada punto.

El potencial hídrico de las hojas (LWP) se determinó en discos de $5 \mathrm{~mm}$ extraídos de plantas cultivadas en DC usando el método del punto de rocío mediante una cámara C-52 (Wescor) conectada a un psicrómetro (Ps-10) y a un microvoltímetro de punto de rocío (modelo HT-33T; Wescor). Las medidas se realizaron de acuerdo con las instrucciones de los fabricantes 0,7 y 14 días tras dejar de regar las plantas. Los valores de LWP se determinaron en tres discos obtenidos de tres hojas pertenecientes a seis plantas diferentes para cada punto y genotipo. El experimento se repitió dos veces.

\section{Determinación de Óxido Nítrico.}

La determinación de óxido nítrico se realizó haciendo uso de las fluoresceínas desarrolladas para este propósito en los últimos años (Kojima, H et al 1998; Kojima, H et al 2001). Estas fluoresceínas tras reaccionar con el óxido nítrico se transforman en un derivado triazol que al 
ser iluminado con una longitud de onda de $500 \mathrm{~nm}$ emite fluorescencia a $515 \mathrm{~nm}$. Se utilizaron dos tipos diferentes de fluoresceínas que aportaron datos complementarios. Por un lado, el uso de la 4,5-diaminofluoresceína (DAF-2) (Calbiochem) nos permite cuantificar los niveles de óxido nítrico en una disolución o en el interior del tejido vegetal pero nunca en el interior celular ya que no es capaz de atravesar la membrana lipídica. Por otro lado, el uso de 3-amino-4-aminometil2',7'-difluorofluoresceína diacetato (DAF-FM DA) (Invitrogen) nos permite visualizar y cuantificar la acumulación de óxido nítrico en el interior celular, ya que esta molécula una vez ha entrado en el contexto del tejido se interna en las células por la acción de las esterasas, siendo esta internalización irreversible y quedando la fluoresceína retenida en el interior celular donde al reaccionar con el óxido nítrico emitirá fluorescencia.

\subsection{Determinación de Óxido Nítrico mediante DAF-FM DA.}

El nivel endógeno de óxido nítrico fue determinado mediante la tinción fluorescente de raíces con la fluoresceína DAF-FM DA como se describe en Guo et al (2003) con pequeñas modificaciones. En resumen, plántulas de 5 a 7 días de edad se incubaron en $10 \mu \mathrm{M}$ DAF-FM DA disuelto en tampón de tinción ( $5 \mathrm{mM}$ MES-KOH, pH 5,7; 0,25 $\mathrm{mM} \mathrm{KCl} ; 1 \mathrm{mM} \mathrm{CaCl}_{2}$ ) durante 1 hora a temperatura ambiente en oscuridad. Después de 3 lavados con tampón de tinción durante 10 minutos cada uno, las plántulas se trataron con diferentes compuestos (1 mM SA ó $50 \mu \mathrm{M}$ ABA) o no se trataron (control). En el caso de la determinación de óxido nítrico en condiciones de oscuridad/luz roja o tras la aplicación de $\mathrm{GA}_{3}$, plántulas de 4 días crecidas en oscuridad fueron incubadas durante 1 hora en oscuridad o en luz roja con DAF-FM DA, o bien, se pre-trataron $\left(\mathrm{GA}_{3}\right)$ o no (control) con $50 \mu \mathrm{M} \mathrm{GA}$ durante $2,5 \mathrm{~h}$ y se incubaron posteriormente con DAF-FM DA tal y como se ha descrito anteriormente. La fluorescencia dependiente de óxido nítrico fue detectada y registrada con el microscopio de fluorescencia Eclipsee 600 (Nikon) o mediante el microscopio confocal TCS SL (Leica) utilizando los mismos parámetros entre los tratamientos. La especificidad de la fluorescencia por el óxido nítrico se demostró pre-tratando las plántulas con 0,5mM de cPTIO (Sigma-Aldrich) (un secuestrador de óxido nítrico) antes de incubarlas con la fluoresceína.

\subsubsection{Cuantificación de la fluorescencia.}

Para cuantificar la fluorescencia, se siguió el método descrito por García-Mata y Lamattina (2007) con alguna modificación. Las imágenes fueron procesadas con Photoshop, obteniendo el histograma de cada una. Mediante la herramienta de enmarcado, se analizaron diferentes áreas dentro de cada imagen, dando un valor de fluorescencia promedio de cada imagen y dividiendo este valor por el área analizada, obteniendo así el valor relativo de fluorescencia por unidad de 
superficie. Al valor promedio correspondiente a las raíces de Col-0 sin tratamiento se le asignó el valor $100 \%$, y la fluorescencia de los demás genotipos se calculó como un valor relativo a éste. Cada experimento fue repetido al menos tres veces, analizando al menos seis plántulas en cada uno.

\subsection{Determinación de Óxido Nítrico mediante DAF-2.}

El método descrito anteriormente para la fluoresceína DAF-FM DA funciona muy bien en raíces ya que éstas no presentan autofluorescencia. Sin embargo, en tejidos verdes, la presencia de clorofilas dificulta mucho el análisis ya que su autofluorescencia interfiere con la del DAF-FM DA. Se han descrito varios métodos para el uso de esta fluoresceína en tejidos de la parte aérea de la planta, pero todos ellos suponen una manipulación muy invasiva de la muestra. Por ejemplo, el más utilizado es la obtención de "peelings" (fracciones epidérmicas) de la hoja y su posterior tinción con la fluoresceína. Para nosotros estas manipulaciones van a suponer, sin duda, una gran producción de óxido nítrico, haciendo el análisis de esa muestra poco real. Para evitar estas manipulaciones, desarrollamos un método no invasivo hacienda uso de las propiedades de la fluoresceína no permeable DAF-2. Así, plántulas enteras de 10-15 días de edad, se sumergieron en $650 \mu \mathrm{L}$ de $10 \mu \mathrm{M}$ DAF-2 en PBS por triplicado y se mantuvieron en oscuridad durante 1 hora. 200 $\mu \mathrm{L}$ de cada tubo fueron traspasados a una placa de 96 pocillos, aptas para el uso en un fluorímetro (Costar, Cambridge, MA). La fluorescencia fue cuantificada mediante el uso de un fluorímetro TECAN equipado con un filtro de excitación de $492 \mathrm{~nm}$ y un filtro de emisión de $535 \mathrm{~nm}$. Los valores de fluorescencia fueron normalizados con el peso de las plántulas y con los valores de fluorescencia de plántulas inactivadas térmicamente (calentadas 10 minutos a $99^{\circ} \mathrm{C}$ ). Se muestra como resultado las medias y los errores estándar de tres medidas. El experimento fue repetido tres veces con resultados similares.

\section{Ensayos de germinación.}

Para comprobar la sensibilidad a ABA, las semillas fueron sembradas en medio MS suplementado con $1 \%(\mathrm{p} / \mathrm{v})$ sacarosa, $0,8 \%(\mathrm{p} / \mathrm{v})$ agar y diferentes concentraciones de $( \pm)$-cis, transABA (Sigma) tras haber estratificado las semillas 3 días a $4^{\circ} \mathrm{C}$. La germinación fue contabilizada como la ruptura del endospermo y el establecimiento de plántula como el número de plántulas que presentaban cotiledones verdes y expandidos el día 12 después de la siembra. Para determinar el efecto del estrés osmótico, las semillas de los diferentes fondos genéticos se sembraron en medio suplementado con $125 \mathrm{mM} \mathrm{NaCl}$ o $250 \mathrm{mM}$ Manitol y cuantificadas como se menciona anteriormente. Para todos estos ensayos se utilizaron semillas recogidas al mismo tiempo. Para los ensayos de dormición, las semillas se recogieron frescas a partir de silicuas del tallo principal que 
empezaban a amarillear, correspondientes al estadio 17B (Ferrandiz et al., 1999). Las semillas se sembraron sin previa estratificación en placas MS y la germinación fue contabilizada como la ruptura del endospermo durante seis días consecutivos.

\section{Medidas de la longitud de los hipocotilos.}

Las plántulas, fueron recogidas de las placas Petri, colocadas sobre papel de acetato y escaneadas a 600 d.p.i. Las imágenes fueron analizadas con el programa ImageJ para el cálculo de la longitud de los hipocotilos. Los valores de longitud de los hipocotilos son medias \pm error estándar de al menos tres experimentos independientes (al menos 20 plántulas analizadas por experimento).

\section{Análisis del contenido en antocianinas.}

A partir de muestras de $100 \mathrm{mg}$ de peso fresco correspondientes a plántulas de 5 días de edad cultivadas en oscuridad o luz blanca, sus antocianinas fueron extraídas y cuantificadas en una solución de metanol ácido durante toda la noche a $4^{\circ} \mathrm{C}$ tal y como ha sido descrito (Francis, 1982). El contenido en antocianinas se muestra como la absorbancia a $530 \mathrm{~nm}$ por $\mathrm{mg}$ de peso fresco.

\section{Determinación de la actividad GAPDH.}

Las proteínas utilizadas para el ensayo se extrajeron en $50 \mathrm{mM}$ Tris- $\mathrm{HCl} \mathrm{pH}=7,4$ siendo cuantificadas a continuación. La actividad GAPDH de los extractos fue ensayada de acuerdo con el método descrito por Muñoz-Bertomeu et al (2009) con pequeñas modificaciones. $50 \mu \mathrm{g}$ de proteínas procedentes de plantas tratadas o no con $2 \mathrm{mM}$ de cloruro de 5-amino-3-(4-morfolinil)1,2,3 oxadiazolio ( $\mathrm{SIN}-1)$ se incubaron con la solución de reacción ( $10 \mathrm{mM}$ Tris- $\mathrm{HCl} \mathrm{pH}=7,4 ; 20$ $\mathrm{mM}$ Arsenato; $2 \mathrm{mM}$ NAD; 0,5 mM DTT). La reacción se inició mediante la aplicación de $2 \mathrm{mM}$ D,L-gliceraldehido-3-fosfato en un volumen final de $1 \mathrm{~mL}$. La actividad GAPDH se midió siguiendo la conversión de NAD en NADH a 340 nM durante 4 minutos.

\section{Aislamiento y manipulación de ácidos nucleicos.}

\subsection{Extracción y purificación de ácidos nucleicos.}

Las extracciones de DNA genómico de hojas se llevaron a cabo mediante el método descrito por Edwards (Edwards et al., 1991). Las extracciones de RNA total a partir de diferentes tejidos de Arabidopsis, se realizó siguiendo el protocolo descrito por Logemann y col. (1987). 


\subsection{Cuantificación de ácidos nucleicos.}

La cuantificación de DNA y RNA se realizó haciendo uso del espectrofotómetro ND1000 (NanoDrop Technologies) que permite la medida directa de la concentración de una muestra sin diluir utilizando volúmenes de un microlitro.

\subsection{Manipulación de ácidos nucleicos.}

\subsubsection{Retrotranscripción (RT) del RNA.}

En primer lugar, las muestras de RNA se sometieron a un tratamiento con DNAsa utilizando el kit Turbo DNA-freeTM (Ambion) siguiendo las instrucciones indicadas por el fabricante. La síntesis de la primera hebra de cDNA se realizó usando la enzima RevertAid ${ }^{\mathrm{TM}} \mathrm{H}$ Minus M-MuLV Reverse Transcriptase (MBI Fermentas) o la M-MLV Reverse Transcriptase (USB) partiendo, de 1 $\mu \mathrm{g}$ de RNA libre de DNA. Las reacciones de RT se llevaron a cabo en un volumen final de $20 \mu \mathrm{L}$.

\subsubsection{Amplificación del DNA mediante PCR.}

Las reacciones en cadena de la polimerasa (PCR) se realizaron en un volumen final de $25 \mu \mathrm{L}$

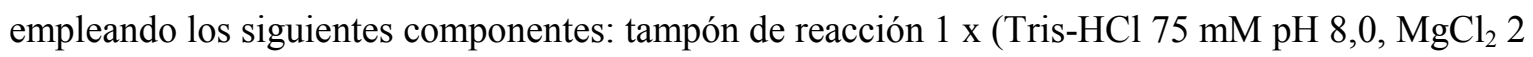
$\mathrm{mM}, \mathrm{KCl} 5 \mathrm{mM},\left(\mathrm{NH}_{4}\right)_{2} \mathrm{SO}_{2} 20 \mathrm{mM}$ y 0,0001\% BSA), dNTPs $200 \mu \mathrm{M}, 400 \mathrm{nM}$ de los oligonucleótidos utilizados como cebadores específicos y 1 U de DNA polimerasa (Netzyme N.E.E.D.). Para cada caso se empleó un programa adecuado en función de la secuencia de los cebadores y de la longitud de los fragmentos amplificados. Las secuencias de los cebadores se detallan en la Tabla M2.

\subsubsection{Determinación de los niveles de transcrito.}

\subsubsection{PCR semicuantitativa.}

Para analizar los niveles de transcrito mediante RT-PCR semicuantitativa se realizaron PCRs con oligonucleótidos específicos para cada gen de interés incluyendo en todos los casos la amplificación del gen endógeno UBQ10 como control de la reacción, siendo el DNA molde empleado cDNA obtenido a partir de RT de RNA total libre de DNA.

\subsubsection{PCR cuantitativa a tiempo real.}


Los oligonucleótidos utilizados como cebadores específicos para cada gen en las reacciones de PCR cuantitativa fueron diseñados a partir de las regiones de cDNA de interés con el programa Primer Express 2.0 utilizando los parámetros por defecto en el caso de no encontrar alguna referencia donde ya se hubieran diseñado los oligonucleótidos. Al final de cada PCR, se realizó una cinética de $\mathrm{T}^{\mathrm{a}} \mathrm{m}$ (curva de disociación) aplicando un gradiente de temperaturas creciente para analizar la especificidad del producto y la presencia de dímeros de los cebadores. Las reacciones de PCR cuantitativa se realizaron en un volumen final de $20 \mu \mathrm{L}$ empleando $10 \mu \mathrm{L}$ de SYBR ${ }^{\circledR}$ Green PCR Master Mix (Applied Biosystems), $1 \mu \mathrm{L}$ de RT y una concentración de $600 \mathrm{nM}$ de cada oligonucleótido. Para cada muestra se realizaron tres PCRs idénticas empleando placas MicroAmpTM Optical 96-well reaction plate (Applied Biosystems) y se llevaron a cabo en los instrumentos 7000 Real-Time PCR System y 7500 Real-Time PCR System (Applied Biosystems). Se utilizó el programa de amplificación recomendado por la casa comercial para los oligonucleótidos diseñados con Primer Express $\left(2 \mathrm{~min} .50^{\circ} \mathrm{C}, 10 \mathrm{~min} .95^{\circ} \mathrm{C}, 40\right.$ ciclos de $15 \mathrm{~s} 95$ ${ }^{\circ} \mathrm{C}, 1 \mathrm{~min} ., 60^{\circ} \mathrm{C}$ ). Los valores de expresión génica se calcularon mediante la cuantificación de la fluorescencia en un punto de la fase exponencial de la reacción de amplificación (umbral) asociado a un número de ciclos concreto para cada gen $(\mathrm{Ct})$. A partir del parámetro $\mathrm{Ct}$ se calcularon para cada experimento los valores de expresión relativa de los genes de interés en las distintas muestras respecto a la muestra control, normalizados con el nivel de expresión obtenido para el gen constitutivo $A C T 2 / 8$ en las mismas muestras, según la fórmula:

$$
2-\left(\begin{array}{c}
\text { Ct gen A - Ct ACT2/8 } \\
\text { (muestra problema) }
\end{array}-\begin{array}{c}
\text { Ct gen A - Ct ACT2/8 } \\
\text { (muestra control) }
\end{array}\right)
$$

\subsection{Manipulación de microorganismos para transformación de vectores plasmídicos.}

\subsubsection{Obtención de células competentes para transformación por choque térmico.}

Una colonia de E. coli $\mathrm{DH} 5 \alpha$ aislada por triple estría se cultivó en $1 \mathrm{~mL}$ de medio LB estéril a $37^{\circ} \mathrm{C}$ en agitación (200 r.p.m.) durante una noche. Se utilizó un volumen de 0,5 mL de este cultivo para inocular $200 \mathrm{~mL}$ de medio LB estéril en un matraz Erlenmeyer de 1 L y se incubó a $37^{\circ} \mathrm{C}$ en agitación (200 r.p.m.) hasta que el cultivo bacteriano alcanzó una $\mathrm{DO}_{600}$ de 0,5-0,6, indicativa del estado de fase exponencial de las bacterias. A continuación, el cultivo, previamente enfriado en hielo durante 10 min., se centrifugó a 5000 r.p.m. durante 10 min. a $4{ }^{\circ} \mathrm{C}$ manteniendo las condiciones de esterilidad. El sedimento se lavó con $20 \mathrm{~mL}$ de $\mathrm{CaCl}_{2} 50 \mathrm{mM}$ estéril y frío, manteniendo esta suspensión durante 3 horas en hielo, y se centrifugó posteriormente durante 10 min. a 5000 r.p.m. a $4{ }^{\circ} \mathrm{C}$. Por último, el sedimento bacteriano se resuspendió en $10 \mathrm{~mL}$ de una solución $\mathrm{CaCl}_{2} 50 \mathrm{mM}$ y $15 \%$ (v/v) de glicerol estéril y frío, se fraccionó en alícuotas de $200 \mu \mathrm{L}$ 
por tubo Eppendorf ${ }^{\circledR}$ que se congelaron inmediatamente en $\mathrm{N}_{2}$ líquido durante 5 min. y se almacenaron a $-80{ }^{\circ} \mathrm{C}$ hasta su utilización. En cada tanda, se realizaron las pruebas pertinentes de eficiencia de transformación y de control de posibles contaminaciones que validaban el uso de estas células para transformar.

\subsubsection{Transformación de células competentes por choque térmico.}

La transformación de células competentes E. coli DH5a y BL21(DE3) se llevó a cabo mediante choque térmico según se describe en Sambrook y col. (1989).

\subsubsection{Purificación de plásmidos bacterianos.}

Las colonias de E. coli potencialmente transformadas se seleccionaron por resistencia a antibiótico. Las colonias elegidas, normalmente 10 por transformación, se cultivaron en tubos estériles con $4 \mathrm{~mL}$ de medio LB líquido estéril incubándolas a $37{ }^{\circ} \mathrm{C}$ en agitación (250 r.p.m.) durante una noche. Las extracciones de DNA plasmídico se realizaron mediante el procedimiento de lisis alcalina rápida según Sambrook y col. (1989) o mediante sistemas comerciales.

\section{Análisis de proteínas.}

\subsection{Extracción de proteínas.}

Las proteínas procedentes de diferentes muestras biológicas congeladas en $\mathrm{N}_{2}$ líquido fueron extraídas con el tampón TBS (Tris-HCl $10 \mathrm{mM} \mathrm{pH} \mathrm{7,4,} \mathrm{NaCl} 150 \mathrm{mM}$ ) con 1\% (v/v) de mezcla de inhibidores de proteasas (Sigma-Aldrich). Los extractos de proteínas fueron cuantificados siguiendo el método descrito por Bradford (1976).

\subsection{Electroforesis de proteínas y Western blot.}

Las muestras $(10-15 \mu \mathrm{g})$ de proteínas fueron separadas en geles SDS-PAGE al 8\%, 10\%, $12,5 \%$ o $15 \%$ de acrilamida según la masa molecular de la proteína a detectar. Los geles se tiñeron con Coomassie empleando el reactivo de tinción EZBlue Gel Staining Reagent (Sigma-Aldrich) o con nitrato de plata empleando el kit PlusOne Silver Staining Kit; Proteín (GE) para visualizar el patrón de las proteínas o, alternativamente, se transfirieron a membrana como se describe a continuación.

Una vez terminada la electroforesis, las proteínas fueron electrotransferidas a una membrana de nitrocelulosa (Hybond-ECL, GE Healthcare) en tampón de transferencia (Tris $25 \mathrm{mM}$, glicina 
$192 \mathrm{mM}$, metanol $20 \%(\mathrm{v} / \mathrm{v}))$ a $100 \mathrm{~V}$ durante $90 \mathrm{~min}$. a $4{ }^{\circ} \mathrm{C}$ o fijando $30 \mathrm{~V}$ y $90 \mathrm{~mA}$ para una transferencia durante toda la noche a $4^{\circ} \mathrm{C}$. La membrana se lavó brevemente con agua y se tiñó con Pounceau-S para verificar la transferencia y el control de carga de las muestras.

Las membranas se incubaron con diferentes tampones dependiendo del anticuerpo utilizado. Como norma general las membranas se bloquearon durante 1 hora a temperatura ambiente, se lavaron $2 \times 1$ minuto con T-TBS, se incubaron con el anticuerpo primario durante una noche a $4^{\circ} \mathrm{C}$, se lavaron 3X10 minutos con T-TBS, se incubaron con el anticuerpo secundario durante 1 hora a temperatura ambiente y se lavaron finalmente 3 X10 minutos con T-TBS. Las condiciones de incubación se resumen en la Tabla M1.

Las proteínas se detectaron mediante el kit Western blot ECL (GE Healthcare) para la mayoría de casos y excepcionalmente para proteínas muy poco abundantes con el kit ECL Advance Western Blotting Detection Kit (GE Healthcare), tal y como recomiendan los fabricantes. Las proteínas se visualizaron exponiendo una película fotográfica Fuji SuperRx (Fujifilm) y revelándola mediante una procesadora automática M-35-X-OMAT (Kodak) o, alternativamente, mediante el equipo LAS-3000 (Fuji) que incorpora una cámara CCD capaz de detectar la luminiscencia producida por los reactivos ECL sin necesidad de utilizar películas fotográficas.

\subsection{Immunoprecipitación de proteínas nitradas en tirosina.}

Con la finalidad de estudiar la naturaleza de las proteínas nitradas en tirosina en Arabidopsis thaliana nos vimos en la necesidad de desarrollar un método que nos permitiera enriquecer las muestras en proteínas nitradas. Para ello nos servimos de los métodos clásicos de immunoprecipitación y de la disponibilidad de anticuerpos comerciales que son capaces de unirse a los residuos de tirosina de las proteínas que han sido modificados por el óxido nítrico formando residuos de 3-NitroTirosina (3-nitroY; 3-NY). Así pues, estos anticuerpos reconocen específicamente residuos de 3-NY. Para este propósito elegimos el anticuerpo monoclonal anti-3NY de la casa comercial Cayman chemicals por haber demostrado una alta afinidad por residuos de 3-NY de proteínas. El método de immunoprecipitación seguido es el que se describe a continuación.

En primer lugar, se confirmó la integridad de los extractos de proteínas mediante electroforesis SDS-PAGE y posterior tinción con Coomasie. Los extractos que pasaron esta validación fueron llevados a una concentración de $1 \mathrm{mg} / \mathrm{mL}$ en un volumen de $1 \mathrm{~mL}$ con TBS. Para eliminar las proteínas que se unen inespecíficamente a la proteína A-agarosa (EZview, Sigma-Aldrich), los extractos ( $4 \times 1 \mathrm{mg})$ se incubaron con $50 \mu \mathrm{L}$ de proteína A-agarosa durante 4 horas a $4^{\circ} \mathrm{C}$ en agitación leve. Tras sedimentar por centrifugación (13.000 r.p.m., $\left.4^{\circ} \mathrm{C}\right)$ la proteína A-agarosa unida a las proteínas a eliminar, se traspasó el sobrenadante a un nuevo tubo con mucho 
cuidado de no incorporar nada de proteína A-agarosa. Tras este primer paso, se añadió $0,1 \mu \mathrm{g}$ de anticuerpo anti-3-NY y se incubó durante una noche a $4^{\circ} \mathrm{C}$ en agitación leve. Para recuperar las proteínas unidas al anticuerpo, se añadieron $60 \mu \mathrm{L}$ de proteína A-agarosa y se dejó incubando en agitación leve durante 4 horas a $4^{\circ} \mathrm{C}$. Tras eliminar la fracción no unida por centrifugación y eliminación del sobrenadante, el sedimento que contiene las proteínas unidas al anticuerpo y a la proteína A-agarosa se lavó 3 veces con TBS para eliminar aquellas proteínas que se han unido inespecíficamente al anticuerpo. En cada lavado, los tubos se mantuvieron durante 2 minutos en agitación leve para facilitar el lavado y se volvieron a sedimentar los complejos proteínaanticuerpo-proteína A-agarosa para eliminar cada uno de los lavados. Tras el último lavado, se añadieron $100 \mu \mathrm{L}$ tampón de elución (1\% SDS, $100 \mathrm{mM}$ DTT, $50 \mathrm{mM}$ Tris-HCl pH=7.6) y se incubó a $95^{\circ} \mathrm{C}$ durante 5 minutos. La elución se realizó 3 veces para asegurar la total elución de las proteínas. La recuperación del eluido se llevó a cabo con la ayuda de jeringuillas de insulina para recuperar el máximo eluido con la menor incorporación de proteína A-agarosa. Los tres eluidos de cada uno de los $4 \mathrm{mg}$ de proteína immunoprecipitada se combinaron y se filtraron con filtros de $0,2 \mu \mathrm{m}$ (Costar) para eliminar los posibles restos de proteína A-agarosa. Los eluidos fueron entonces precipitados, combinados y procesados con el kit 2-D Clean Up Kit (GE Healthcare) para su posterior análisis por 2-DE y/o LC-MS/MS.

\subsection{Electroforesis bi-dimensional (2-DE).}

Para la primera dimensión (separación de las proteínas en función de su punto isoeléctrico), las muestras de proteínas a separar $(100 \mu \mathrm{g})$ se disolvieron en DeStreak Rehydration Solution (GE Healthcare). Con estas muestras se rehidrataron tiras de acrilamida de $18 \mathrm{~cm}$ con un rango de $\mathrm{pH}$ 3-10 no lineal (Immobiline Dry-Strips, GE Healthcare) pasivamente, durante una noche a temperatura ambiente. Una vez las tiras se encontraban rehidratadas, se sometieron a un programa de electroforesis específico para este tipo de muestra mediante el sistema de electroforesis IPGphor 3 (GE Healthcare). Las condiciones de electroforesis fueron: 1 hora $50 \mathrm{~V}$ (step-and-hold), 1 hora $150 \mathrm{~V}$ (gradiente), 1 hora 30 minutos $500 \mathrm{~V}$ (gradiente), 1 hora 30 minutos $1000 \mathrm{~V}$ (gradiente), 2 horas $4000 \mathrm{~V}$ (gradiente), 2 horas $8000 \mathrm{~V}$ (gradiente) y 7 horas $8000 \mathrm{~V}$ (step-andhold). Una vez finalizada la electroforesis de la primera dimensión, las tiras se redujeron con DTT $1 \mathrm{mg} / \mathrm{mL}$ durante 15 minutos seguidas por una alquilación con iodoacetamida $25 \mathrm{mg} / \mathrm{mL}$ durante 15 minutos más. Ambos tratamientos se realizaron en tampón de equilibración (6 M urea, $75 \mathrm{mM}$ Tris- $\mathrm{HCl} \mathrm{pH}$ 8.8, $29.3 \%$ glicerol, $2 \%$ SDS y $0.002 \%$ azul de bromofenol). Una vez equilibradas, las tiras se introdujeron en geles de $24 \mathrm{~cm}$ del $12,5 \%$ de acrilamida cuidadosamente desgaseados y polimerizados previamente. Los geles se montaron en el sistema de electroforesis EttanDaltSix (Ge Healthcare) y la electroforesis de los mismos se realizó siguiendo las instrucciones de los fabricantes para una electroforesis durante toda la noche. A continuación los geles se tiñeron con 
el reactivo fluorescente DeepPurple (GE Healthcare) tal y como recomiendan los fabricantes. Los geles se escanearon y digitalizaron con el escáner Typhoon (GE Healthcare) y las imágenes se analizaron mediante el programa ImageMaster Platinum 5.0 (GE Healthcare).

Para recoger los diferentes spots de interés para su posterior identificación, los geles fueron procesados con el robot Ettan Spot Picker. Una vez asignadas las coordenadas correspondientes a las imágenes digitales de los geles tal y como indican los fabricantes el robot muestreo los spots de interés y los deposito en placas de 96 pocillos.

\subsection{Identificación de proteínas mediante espectrometría de masas.}

Todas las identificaciones de proteínas que aparecen en este trabajo fueron llevadas a cabo en el servicio de proteómica del Centro de Investigación Príncipe Felipe (http://www.cipf.es/RESEARCH/group.aspx?id=49), miembros de Proteored. Las condiciones en las que se analizaron las diferentes muestras fueron las siguientes.

Las muestras a analizar por MALDI-TOF fueron digeridas con tripsina (Promega, grado de secuenciación), secadas en una centrífuga de vacío y resuspendidas en un volumen de $7 \mu \mathrm{L}$ de ácido trifluoroacético (TFA) al 0,1\%. $1 \mu \mathrm{L}$ se estampó en la placa MALDI. Después de dejar secar a temperatura ambiente se le añadió medio microlitro de matriz ( $5 \mathrm{mg} / \mathrm{mL}$ CHCA (Sigma-Aldrich) en 0,1\% TFA-CAN/agua 1:1 (v/v)) y se dejó secar a temperatura ambiente. Los datos MALDI MS y MS/MS fueron obtenidos con un espectrómetro de masas 4700 Proteomics analyzer (Applied Biosystems). Las muestras sin una identificación satisfactoria se analizaron posteriormente por LC-MS/MS.

La separación de péptidos por LC-MS/MS se realizó en un sistema de nano-LC Ultimate nano-LC system (LC Packings) y con un espectrómetro de masas QSTAR XL Q-TOF hybrid mass spectrometer (MDS Sciex-Applied Biosystems). Las muestras $(5 \mu \mathrm{L})$ fueron incorporadas al sistema mediante un sistema automatizado (FAMOS autosampler, LC Packings) a un caudal de 40 $\mu \mathrm{L} /$ minuto y los péptidos fueron retenidos en una pre-columna PrepMap C18 (5 mm, $300 \mathrm{~m}$ i. d., LC Packings). Los péptidos fueron entonces eluidos en la columna analítica PepMap C18 (15 cm, $75 \mathrm{~m}$ i. d., LC Packings) a un caudal de $200 \mathrm{~nL} /$ minuto y separados usando un gradiente de 55 minutos del 15-50\% ACN. El espectrómetro de masas QSTAR XL se operó en un modo de adquisición dependiente de información, en el que se realizaba un scan TOF MS en valores desde $400-2000 \mathrm{~m} / \mathrm{z}$ de 1 segundo, seguido de un ion scan del producto de 3 segundos.

\subsection{Síntesis, purificación y nitración de AtMS1.}

Un plásmido (pET21b) que contenía el cDNA de AtMS1 fusionado a una etiqueta de 6 histidinas (6xHIS) se utilizó para transformar células competentes de E-coli BL21(DE3) (Sigma- 
Aldrich) para la producción de la proteína recombinante. Para la inducción de la producción de proteína recombinante, cultivos celulares con una D.O. $=0,7$ fueron tratados con $1 \mathrm{mM}$ de isopropil $\beta$-D-1-tiogalactopiranósido (IPTG) durante 5 horas. La producción de la proteína recombinante se confirmó lisando cultivos inducidos y no inducidos con Laemli buffer a $95^{\circ} \mathrm{C}$ durante 10 minutos y resolviendo el patrón de proteínas mediante 8\% SDS-PAGE y posterior tinción con Coomasie, así como por Western-blot mediante un anticuerpo anti-pentaHIS (Quiagen).

La purificación de la proteína se llevó a cabo con el kit QIAexpress Ni-NTA Fast Start Kit (Qiagen) siguiendo las recomendaciones del fabricante.

La proteína purificada AtMS1 fue nitrada in vitro tratándola o no con un tampón nitrante como se había descrito con anterioridad (Chen et al., 2008b). En este método, $10 \mu \mathrm{L}$ de proteína purificada se incuba con $500 \mu \mathrm{M} \mathrm{H}_{2} \mathrm{O}_{2}$ y $500 \mu \mathrm{M} \mathrm{NaNO}_{2}$ en $0,1 \mathrm{M}$ PBS a $37^{\circ} \mathrm{C}$ en oscuridad. Para limpiar la proteína de las impurezas de la reacción, el volumen de reacción se filtra con un filtro de $10 \mathrm{kDa}$ (Microcon, Ambion). Las proteínas se analizaron mediante SDS-PAGE y Western blot. La nitración de la proteína se confirmó con el anticuerpo anti-3-NY y el control de carga con el anticuerpo anti-pentaHIS. Se corrió un gel en paralelo y se tiñó con Coomasie, se cortaron las bandas y tras extraer y digerir la proteína, sus péptidos fueron analizados por LC-MS/MS como se ha descrito anteriormente.

\subsection{Modelado y análisis estructural de proteínas.}

Los modelos 3D de las proteínas fueron generados por homología mediante los programas de SWISS-MODEL (Arnold et al., 2006) usando las coordenadas de GAPDH de rata (código PDB 2VYN), de la Hidroximetiltransferasa de Mycobacterium tuberculosis (código PDB 3HF7), Transcetolasa de maíz (código PDB 1ITZ), RuBisCO de espinaca (código PDB 1IR1) y Manitol deshidrogenasa de Cladosporium harbarum (código PDB 3GDF) como moldes. Para la Metionina sintasa se utilizó la estructura de Arabidopsis thaliana (código PDB 1U1J). La calidad de los modelos fue evaluada por ANOLEA, Verify3D y Procheck (Bowie et al., 1991; Laskowski et al., 1996; Melo y Feytmans 1998)

\section{Microscopía confocal en plantas transgénicas $p R G A:: G F P-R G A$}

Las plantas $p R G A:: G F P-R G A$ expresan la proteína RGA, fusionada a la proteína fluorescente GFP bajo la regulación de la propia secuencia promotora del gen RGA, lo que determina que los patrones de expresión y la localización subcelular de la proteína GFP-RGA en planta, es decir, in vivo, sean los mismos que los de la proteína RGA endógena. 
La fluorescencia de plántulas $p R G A: \because G F P-R G A$ se detectó mediante el microscopio confocal TCS SL (Leica) equipado con un objetivo de inmersión de aceite 40X. Para analizar la fluorescencia de GFP-RGA y la autoflurescencia de los cloroplastos, las muestras fueron excitadas con un láser de Argón a $488 \mathrm{~nm}$. La emisión de fluorescencia fue registrada entre 497-537 nm para GFP (representada en verde) y 579-647 nm para la autofluorescencia de los cloroplastos (representada en rojo). Las proyecciones medias de reconstrucciones de apilamientos en Z (10 cortes de 3 micras cada uno) fueron tomadas y se representan en la figura correspondiente. Se analizaron 10 plántulas en cada experimento, en tres experimentos independientes.

Tabla M1. Anticuerpos utilizados en este trabajo.

\begin{tabular}{|c|c|c|c|c|c|c|c|c|}
\hline Anticuerpo & Tipo & Dilución/Buffer & Bloqueo & Lavados & Secundario & & Origen & Referencia \\
\hline anti-3NY & Monoclonal & 1:1000/TBS-T 3\% Top-Block & TBS-T 3\% Top-Block & TBS-T & 1:10000/TBS-T 3\% Top-Block & mouse & Cayman Chemicals & 189542 \\
\hline anti-pentaHIS & S Monoclonal & 1:8000/TBS 3\% BSA & TBS $3 \%$ BSA & TBS-T & $1: 10000 /$ TBS $10 \%$ Leche en polvo & mouse & Quiagen & \\
\hline anti-GFPm & Monoclonal & 1:8000/TBS-T 5\% Leche en polvo & TBS-T 5\% Leche en polvo & TBS-T & 1:10000/TBS-T $5 \%$ Leche en polvo & mouse & Clontech & $632380 / 632381$ \\
\hline anti-TUB & Monoclonal & 1:10000/TBS-T 5\% Leche en polvo & TBS-T 5\% Leche en polvo & TBS-T & 1:10000/TBS $5 \%$ Leche en polvo & mouse & Sigma-Aldrich & T 6074 \\
\hline anti-PHYB & Monoclonal & 1:2500/TBS-T 5\% Leche en polvo & TBS-T 5\% Leche en polvo & TBS-T & 1:10000/TBS-T 5\% Leche en polvo & mouse & Akira Nagatani lab & \\
\hline anti-HIS & Monoclonal & $1: 500 /$ TBS $3 \%$ BSA & TBS $3 \%$ BSA & TBS-T & 1:10000/TBS 5\% Leche en polvo & mouse & Santa Cruz & sc-803 \\
\hline anti-HA & Monoclonal & 1:5000/T-TBS 5\% Leche en polvo & TBS-T 5\% Leche en polvo & TBS-T & 1:10000/TBS-T 5\% Leche en polvo & mouse & AbCam & ab9110 \\
\hline anti-GRP & Policlonal & 1:2500/TBS-T 5\% Leche en polvo & TBS-T $5 \%$ Leche en polvo & TBS-T & 1:10000/TBS-T $5 \%$ Leche en polvo & rabbit & Dorothee Staiger & \\
\hline anti-OASTL & Policlonal & 1:5000/TBS $2 \%$ Leche en polvo & TBS-T $5 \%$ Leche en polvo & TBS-T & 1:10000/TBS $2 \%$ Leche en polvo & rabbit & Rüdiger Hell/Cecilia Gotor & \\
\hline anti-CA & Policlonal & 1:3000/TBS-T 5\% Leche en polvo & TBS-T 5\% Leche en polvo & TBS-T & 1:10000/TBS-T 5\% Leche en polvo & rabbit & Dominique Rumeau & \\
\hline anti-GAPDH & Policlonal & 1:10000/TBS-T 5\% Leche en polvo & TBS-T 5\% Leche en polvo & TBS-T & 1:10000/TBS-T $5 \%$ Leche en polvo & rabbit & Renate Scheibe & \\
\hline anti-PKL & Policlonal & 1:5000/TBS-T 1\% BSA & TBS-T $1 \%$ BSA & TBS-T & 1:10000/TBS-T 1\% BSA & rabbit & Joe Ogas & \\
\hline anti-FBPase & Policlonal & 1:2000/TBS-T 5\% Leche en polvo & TBS-T 5\% Leche en polvo & TBS-T & 1:10000/TBS-T $5 \%$ Leche en polvo & rabbit & Mariam Sahrawy & \\
\hline anti-MYC-Ct & t Policlonal & 1:10000/TBS-T 5\% Leche en polvo & TBS-T 5\% Leche en polvo & TBS-T & No hace falta-conjugado a HRP & & Sigma-Aldrich & A 5598 \\
\hline
\end{tabular}


Tabla M2. Oligonucleótidos utilizados en este trabajo

\begin{tabular}{|c|c|c|c|c|}
\hline Oligo & Simbolo en figura & Sequencia del oligo & Uso & Referencia \\
\hline iNOS-F & 9 & 5'-CCGTAACGCTGAAACACCTCA-3' & $\begin{array}{c}\text { genotipado varP1-1 } \\
\text { varP RT-PCR }\end{array}$ & Este trabajo \\
\hline iNOS-R & 10 & 5'-TGTTGCTAGTGGCTTTGTCCC-3' & $\begin{array}{l}\text { genotipado varP1-1 } \\
\text { varP RT-PCR }\end{array}$ & Este trabajo \\
\hline AtNOA1.1-LP & 2 & 5'-GCACCTACACCACAGGCAAGC-3' & $\begin{array}{l}\text { genotipado noa1-2 } \\
\text { AtNOA1 RT-PCR }\end{array}$ & Este trabajo \\
\hline AtNOA1.1-RP & 3 & 5'-CCAATTGGCAATGTTGGTCG-3' & $\begin{array}{l}\text { genotipado noa1-2 } \\
\text { AtNOA1 RT-PCR }\end{array}$ & Este trabajo \\
\hline NR1.1-LP & 11 & 5'-CCATGAGGTTCCAGATGAGT-3' & $\begin{array}{l}\text { genotipado } n r 1-1 \\
\text { NIA1 RT-PCR }\end{array}$ & Este trabajo \\
\hline NR1.1-RP & 12 & 5'-TCTATAGCCGGAGAGGAGGCG-3' & $\begin{array}{c}\text { genotipado } n r 1-1 \\
\text { NIA1 RT-PCR }\end{array}$ & Este trabajo \\
\hline NR1.2-LP & 13 & 5'-TGGTAGGTATCACGTTCAAAAG-3' & genotipado $n r 1-2$ & Este trabajo \\
\hline NR1.2-RP & 14 & 5'-GTACCGGGTTTCATCGGTGGT-3' & genotipado $n r 1-2$ & Este trabajo \\
\hline CAPS NR1-F & 4 & 5'-TACGACGACTCCTCAAGCGAC-3' & genotipado nia1 & Este trabajo \\
\hline CAPS NR1-R & 5 & 5'-GGCTATAGATCCCGCATCGAC-3' & genotipado nia1 & Este trabajo \\
\hline NR2.1-LP & 6 & 5'-ACGGCGTGGTTCGTTCTTACA-3' & $\begin{array}{l}\text { genotipado nia2 } \\
\text { genotipado } n r 2-1 \\
\text { NIA2 RT-PCR }\end{array}$ & Este trabajo \\
\hline NR2.1-RP & 7 & 5'-ACCTTCTTCGTCGGCGAGTTC-3' & $\begin{array}{c}\text { genotipado } n r 2-1 \\
\text { genotipado nia2 } \\
\text { NIA2 RT-PCR }\end{array}$ & Este trabajo \\
\hline NR2.2-LP & & 5'-GGTGGATGATGTCAGCTTCT-3' & genotipado $n r 2-2$ & Este trabajo \\
\hline NR2.2-RP & & 5'-AGATTGAATCCGAACCACCCG-3' & genotipado $n r 2-2$ & Este trabajo \\
\hline XOR1-LP & 15 & 5'-TCCGTTGAAAGTAGCAGGCAC-3' & $\begin{array}{c}\text { genotipado xor1-1 } \\
\text { XOR1 RT-PCR }\end{array}$ & Este trabajo \\
\hline XOR1-RP & 16 & 5'-TCCGTTGAAAGTAGCAGGCAC-3' & $\begin{array}{c}\text { genotipado xor1-1 } \\
\text { XOR1 RT-PCR }\end{array}$ & Este trabajo \\
\hline XOR2-LP & 17 & 5'-TGAGAACCATGCGAAGATGCC-3' & $\begin{array}{c}\text { genotipado xor2-1 } \\
\text { XOR2 RT-PCR }\end{array}$ & Este trabajo \\
\hline XOR2-RP & 18 & 5'-GGCGCAGGAAGAAGATGAAGA-3' & genotipado xor2-1 & Este trabajo \\
\hline XOR2-RP2 & & 5'-GGAGCAGAACGAGTTCATGGAGG-3' & XOR2 RT-PCR & Este trabajo \\
\hline SALK LBb1 & 8 & 5'-GCGTGGACCGCTTGCTGCAACT-3' & genotipado líneas SALK & (d) \\
\hline SALK LBb1.3 & 8 & 5'-ATTTTGCCGATTTCGGAAC-3' & genotipado líneas SALK & (d) \\
\hline SAIL LB3 & 1 & 5'-TAGCATCTGAATTTCATAACCAATCTCGATACAC-3' & genotipado líneas SAIL & (a) \\
\hline UBQ10-F & & 5'-GATCTTTGCCGGAAAACAATTGGAGGATGGT-3' & normalizacion RT-PCR & (b) \\
\hline UBQ10-R & & 5'-CGACTTGTCATTAGAAAGAAAGAGATAACAGG-3' & normalizacion RT-PCR & (b) \\
\hline qRD29b-F & & 5'-CTTGGCACCACCGTTGGGACTA-3' & $R D 29 b$ qRT-PCR & Este trabajo \\
\hline qRD29b-R & & 5'-TCAGTTCCCAGAATCTTGAACT-3' & RD29B qRT-PCR & Este trabajo \\
\hline qRAB18-F & & 5'-AAGAAGAACATGGCGTCTTACCA-3' & RAB18 qRT-PCR & Este trabajo \\
\hline qRAB18-R & & 5'-TGCTGCTGGATCGGGTTT-3' & RAB18 qRT-PCR & Este trabajo \\
\hline
\end{tabular}




\begin{tabular}{|c|c|c|c|}
\hline qACT2-F & 5'-TTGTTCCAGCCCTCGTTTGT-3' & normalizacion qRT-PCR & (c) \\
\hline qACT2-R & 5'-TGTCTCGTGGATTCCAGCAG-3' & normalizacion qRT-PCR & (c) \\
\hline qGID1a-F & 5'-gtgacggttagagaccgcga-3' & & Este trabajo \\
\hline qGID1a-R & 5'-tccctcgggtaaaaacgctt-3' & & Este trabajo \\
\hline qGID1b-F & 5'-ttacggtcaaggaactcggc-3' & & Este trabajo \\
\hline qGID1b-R & 5'-tcgccctgacggttctttc-3' & & Este trabajo \\
\hline qGID1c-F & 5'-cggctcaaatcttcgatctgg-3' & & Este trabajo \\
\hline qGID1c-R & 5'-ttggcatttgcagggactttc-3' & & Este trabajo \\
\hline qSLY1-F & 5'-gggcagaaccagctcagatc-3' & & Este trabajo \\
\hline qSLY1-R & 5'-tcttcggaagccaccaagc-3' & & Este trabajo \\
\hline qPIF1-F & 5'- GTTGCTTTCGAAGGCGGTT-3' & & (e) \\
\hline qPIF1-R & 5'- GCGCTAGGACTTACCTGCGT-3' & & (e) \\
\hline qPIF3-F & 5'-CCACGGACCACAGTTCCAAG-3' & & (e) \\
\hline qPIF3-R & 5'ATCGCCACTGGTTGTTGTTG-3' & & (e) \\
\hline qPIF4-F & 5'-GAGATTTAGTTCACCGGCGG-3' & & (e) \\
\hline qPIF4-R & 5'-GGCACAGACGACGGTTGTT-3' & & (e) \\
\hline qPIF5-F & 5'-TTGCAGCTCCAAGCACAGAA-3' & & (f) \\
\hline qPIF5-R & 5'-GTACCTAGCGAGCTGCTCCG- 3' & & (f) \\
\hline qRGL1-F & 5'-TCAGTGGCGGTTAACTCGGT-3' & & Este trabajo \\
\hline qRGL1-R & 5'-GGGATGAGCTAAGAGGCGATG-3' & & Este trabajo \\
\hline qRGL2-F & 5'-GACGGCGCGTAGAGTTCAC-3' & & Este trabajo \\
\hline qRGL2-R & 5'-TGCATCCCTTGATTAAGCCC-3' & & Este trabajo \\
\hline qRGL3-F & 5'-GCTGGAGAATCTGAGCCTCG-3' & & Este trabajo \\
\hline qRGL3-R & 5'-AGTAATCCCACGCGCTTGAC-3' & & Este trabajo \\
\hline qRGA-F & 5'-ACTTCGACGGGTACGCAGAT-3' & & Este trabajo \\
\hline qRGA-R & 5'-TGTCGTCACCGTCGTTCCT-3' & & Este trabajo \\
\hline qGAI_3UTR-F & 5'AATGAATTGATCTGTTGAACCGG-3' & & Este trabajo \\
\hline qGAI_3UTR-R & 5'-GGCTTCGGTCGGAATCTATC-3' & & Este trabajo \\
\hline
\end{tabular}

(a) Mc Elver, J et al. Genetics, Vol. 159, 1751-1763, December 2001

(b) Cruz Castillo M et al. Plant Physiology Vol.135 (1), 85-94, May 2004

(c) Castillo MC and León J. Journal of Experimental Botany, Vol. 59, No. 8, 2171-2179, May 2008

(d) Alonso, J.M. et al Science, Vol. 301, 653-657, 2003.

(e) Alabadi et al., 2008

(f) Stavang et al., 2009 


\section{Bibliografía}

Abello, N., Barroso, B., Kerstjens, H. A., Postma, D. S. y Bischoff, R. (2010). Chemical labeling and enrichment of nitrotyrosine-containing peptides. Talanta 80(4): 1503.

Abello, N., Kerstjens, H. A., Postma, D. S. y Bischoff, R. (2009). Protein tyrosine nitration: selectivity, physicochemical and biological consequences, denitration, and proteomics methods for the identification of tyrosine-nitrated proteins. J Proteome Res 8(7): 3222.

Achard, P., Cheng, H., De Grauwe, L., Decat, J., Schoutteten, H., Moritz, T., Van Der Straeten, D., Peng, J. y Harberd, N. P. (2006). Integration of plant responses to environmentally activated phytohormonal signals. Science 311(5757): 91.

Achard, P. y Genschik, P. (2009). Releasing the brakes of plant growth: how GAs shutdown DELLA proteins. J Exp Bot 60(4): 1085.

Achard, P., Gong, F., Cheminant, S., Alioua, M., Hedden, P. y Genschik, P. (2008a). The cold-inducible CBF1 factor-dependent signaling pathway modulates the accumulation of the growth-repressing DELLA proteins via its effect on gibberellin metabolism. Plant Cell 20(8): 2117.

Achard, P., Gusti, A., Cheminant, S., Alioua, M., Dhondt, S., Coppens, F., Beemster, G. T. y Genschik, P. (2009). Gibberellin signaling controls cell proliferation rate in Arabidopsis. Curr Biol 19(14): 1188.

Achard, P., Liao, L., Jiang, C., Desnos, T., Bartlett, J., Fu, X. y Harberd, N. P. (2007). DELLAs contribute to plant photomorphogenesis. Plant Physiol 143(3): 1163.

Achard, P., Renou, J. P., Berthome, R., Harberd, N. P. y Genschik, P. (2008b). Plant DELLAs restrain growth and promote survival of adversity by reducing the levels of reactive oxygen species. Curr Biol 18(9): 656.

Agrawal, L., Chakraborty, S., Jaiswal, D. K., Gupta, S., Datta, A. y Chakraborty, N. (2008). Comparative proteomics of tuber induction, development and maturation reveal the complexity of tuberization process in potato (Solanum tuberosum L.). J Proteome Res 7(9): 3803.

Ahmad, M. y Cashmore, A. R. (1993). HY4 gene of A. thaliana encodes a protein with characteristics of a blue-light photoreceptor. Nature 366(6451): 162.

Al-Sady, B., Kikis, E. A., Monte, E. y Quail, P. H. (2008). Mechanistic duality of transcription factor function in phytochrome signaling. Proc Natl Acad Sci U S A 105(6): 2232.

Al-Sady, B., Ni, W., Kircher, S., Schafer, E. y Quail, P. H. (2006). Photoactivated phytochrome induces rapid PIF3 phosphorylation prior to proteasome-mediated degradation. Mol Cell 23(3): 439.

Alabadi, D. y Blazquez, M. A. (2008). Integration of light and hormone signals. Plant Signal Behav 3(7): 448.

Alabadi, D. y Blazquez, M. A. (2009). Molecular interactions between light and hormone signaling to control plant growth. Plant Mol Biol 69(4): 409.

Alabadi, D., Blazquez, M. A., Carbonell, J., Ferrandiz, C. y Perez-Amador, M. A. (2009). Instructive roles for hormones in plant development. Int J Dev Biol 53(8-10): 1597.

Alabadi, D., Gallego-Bartolome, J., Orlando, L., Garcia-Carcel, L., Rubio, V., Martinez, C., Frigerio, M., Iglesias-Pedraz, J. M., Espinosa, A., Deng, X. W. y Blazquez, M. A. (2008). Gibberellins modulate light signaling pathways to prevent Arabidopsis seedling de-etiolation in darkness. Plant J 53(2): 324.

Alabadi, D., Gil, J., Blazquez, M. A. y Garcia-Martinez, J. L. (2004). Gibberellins repress photomorphogenesis in darkness. Plant Physiol 134(3): 1050. 
Alvarez, C., Lozano-Juste, J., Romero, L. C., Garcia, I., Gotor, C. y Leon, J. (2011). Inhibition of Arabidopsis O-acetylserine(thiol)lyase A1 by tyrosine nitration. J Biol Chem 286(1): 578.

Allakhverdiev, S. I., Kreslavski, V. D., Klimov, V. V., Los, D. A., Carpentier, R. y Mohanty, P. (2008). Heat stress: an overview of molecular responses in photosynthesis. Photosynth Res 98(1-3): 541.

Allen, G. J. y Schroeder, J. I. (2001). Combining genetics and cell biology to crack the code of plant cell calcium signaling. Sci STKE 2001(102): re13.

Amaya, Y., Yamazaki, K., Sato, M., Noda, K. y Nishino, T. (1990). Proteolytic conversion of xanthine dehydrogenase from the NAD-dependent type to the O2-dependent type. Amino acid sequence of rat liver xanthine dehydrogenase and identification of the cleavage sites of the enzyme protein during irreversible conversion by trypsin. J Biol Chem 265(24): 14170.

Antonov, A. V., Schmidt, T., Wang, Y. y Mewes, H. W. (2008). ProfCom: a web tool for profiling the complex functionality of gene groups identified from high-throughput data. Nucleic Acids Res 36(Web Server issue): W347.

Arasimowicz-Jelonek, J., Floryszak-Wieczorek y Kosmala, A. (2011). Are nitric oxide donors a valuable tool to study the functional role of nitric oxide in plant metabolism? Plant Biol (Stuttg) 13(2).

Ariizumi, T., Murase, K., Sun, T. P. y Steber, C. M. (2008). Proteolysis-independent downregulation of DELLA repression in Arabidopsis by the gibberellin receptor GIBBERELLIN INSENSITIVE DWARF1. Plant Cell 20(9): 2447.

Ariizumi, T. y Steber, C. M. (2007). Seed germination of GA-insensitive sleepy1 mutants does not require RGL2 protein disappearance in Arabidopsis. Plant Cell 19(3): 791.

Aslan, M., Ryan, T. M., Townes, T. M., Coward, L., Kirk, M. C., Barnes, S., Alexander, C. B., Rosenfeld, S. S. y Freeman, B. A. (2003). Nitric oxide-dependent generation of reactive species in sickle cell disease. Actin tyrosine induces defective cytoskeletal polymerization. J Biol Chem 278(6): 4194.

Aulak, K. S., Miyagi, M., Yan, L., West, K. A., Massillon, D., Crabb, J. W. y Stuehr, D. J. (2001). Proteomic method identifies proteins nitrated in vivo during inflammatory challenge. Proc Natl Acad Sci U S A 98(21): 12056.

Bacharach, A. D., Markland, F. S., Pellino, A. y Weber, B. H. (1977). Modification of yeast 3phosphoglycerate kinase: isolation and sequence determination of a nitrated active-site peptide and isolation of a carboxyl modified active-site peptide. Biochem Biophys Res Commun 74(1): 165.

Bae, G. y Choi, G. (2008). Decoding of light signals by plant phytochromes and their interacting proteins. Annu Rev Plant Biol 59: 281.

Bahin, E., Bailly, C., Sotta, B., Kranner, I., Corbineau, F. y Leymarie, J. (2011). Crosstalk between reactive oxygen species and hormonal signalling pathways regulates grain dormancy in barley. Plant Cell Environ.

Bailey, P. C., Martin, C., Toledo-Ortiz, G., Quail, P. H., Huq, E., Heim, M. A., Jakoby, M., Werber, M. y Weisshaar, B. (2003). Update on the basic helix-loop-helix transcription factor gene family in Arabidopsis thaliana. Plant Cell 15(11): 2497.

Bailly, C., El Maarouf Bouteau, H. y Corbineau, F. (2008). [Seed dormancy alleviation and oxidative signaling]. J Soc Biol 202(3): 241.

Barbosa-Sicard, E., Fromel, T., Keseru, B., Brandes, R. P., Morisseau, C., Hammock, B. D., Braun, T., Kruger, M. y Fleming, I. (2009). Inhibition of the soluble epoxide hydrolase by tyrosine nitration. J Biol Chem 284(41): 28156.

Barouch, L. A., Harrison, R. W., Skaf, M. W., Rosas, G. O., Cappola, T. P., Kobeissi, Z. A., Hobai, I. A., Lemmon, C. A., Burnett, A. L., O'Rourke, B., Rodriguez, E. R., Huang, P. L., Lima, J. A., 
Berkowitz, D. E. y Hare, J. M. (2002). Nitric oxide regulates the heart by spatial confinement of nitric oxide synthase isoforms. Nature 416(6878): 337.

Barroso, J. B., Corpas, F. J., Carreras, A., Sandalio, L. M., Valderrama, R., Palma, J. M., Lupianez, J. A. y del Rio, L. A. (1999). Localization of nitric-oxide synthase in plant peroxisomes. J Biol Chem 274(51): 36729 .

Basu, S., Keszler, A., Azarova, N. A., Nwanze, N., Perlegas, A., Shiva, S., Broniowska, K. A., Hogg, N. y Kim-Shapiro, D. B. (2010). A novel role for cytochrome c: Efficient catalysis of S-nitrosothiol formation. Free Radic Biol Med 48(2): 255.

Bauer, D., Viczian, A., Kircher, S., Nobis, T., Nitschke, R., Kunkel, T., Panigrahi, K. C., Adam, E., Fejes, E., Schafer, E. y Nagy, F. (2004). Constitutive photomorphogenesis 1 and multiple photoreceptors control degradation of phytochrome interacting factor 3 , a transcription factor required for light signaling in Arabidopsis. Plant Cell 16(6): 1433.

Bechtold, U., Rabbani, N., Mullineaux, P. M. y Thornalley, P. J. (2009). Quantitative measurement of specific biomarkers for protein oxidation, nitration and glycation in Arabidopsis leaves. Plant J 59(4): 661.

Beligni, M. V., Fath, A., Bethke, P. C., Lamattina, L. y Jones, R. L. (2002). Nitric oxide acts as an antioxidant and delays programmed cell death in barley aleurone layers. Plant Physiol 129(4): 1642.

Beligni, M. V. y Lamattina, L. (1999). Nitric oxide protects against cellular damage produced by methylviologen herbicides in potato plants. Nitric Oxide 3(3): 199.

Beligni, M. V. y Lamattina, L. (2000). Nitric oxide stimulates seed germination and de-etiolation, and inhibits hypocotyl elongation, three light-inducible responses in plants. Planta 210(2): 215.

Besson-Bard, A., Gravot, A., Richaud, P., Auroy, P., Duc, C., Gaymard, F., Taconnat, L., Renou, J. P., Pugin, A. y Wendehenne, D. (2009). Nitric oxide contributes to cadmium toxicity in Arabidopsis by promoting cadmium accumulation in roots and by up-regulating genes related to iron uptake. Plant Physiol 149(3): 1302 .

Besson-Bard, A., Griveau, S., Bedioui, F. y Wendehenne, D. (2008a). Real-time electrochemical detection of extracellular nitric oxide in tobacco cells exposed to cryptogein, an elicitor of defence responses. J Exp Bot 59(12): 3407.

Besson-Bard, A., Pugin, A. y Wendehenne, D. (2008b). New insights into nitric oxide signaling in plants. Annu Rev Plant Biol 59: 21.

Bethke, P. C., Badger, M. R. y Jones, R. L. (2004a). Apoplastic synthesis of nitric oxide by plant tissues. Plant Cell 16(2): 332.

Bethke, P. C., Gubler, F., Jacobsen, J. V. y Jones, R. L. (2004b). Dormancy of Arabidopsis seeds and barley grains can be broken by nitric oxide. Planta 219(5): 847.

Bethke, P. C., Libourel, I. G., Aoyama, N., Chung, Y. Y., Still, D. W. y Jones, R. L. (2007). The Arabidopsis aleurone layer responds to nitric oxide, gibberellin, and abscisic acid and is sufficient and necessary for seed dormancy. Plant Physiol 143(3): 1173.

Bethke, P. C., Libourel, I. G. y Jones, R. L. (2006a). Nitric oxide reduces seed dormancy in Arabidopsis. J Exp Bot 57(3): 517.

Bethke, P. C., Libourel, I. G., Reinohl, V. y Jones, R. L. (2006b). Sodium nitroprusside, cyanide, nitrite, and nitrate break Arabidopsis seed dormancy in a nitric oxide-dependent manner. Planta 223(4): 805.

Bewley, J. D. (1997). Seed Germination and Dormancy. Plant Cell 9(7): 1055. 
Birnboim, H. C., Lemay, A. M., Lam, D. K., Goldstein, R. y Webb, J. R. (2003). Cutting edge: MHC class II-restricted peptides containing the inflammation-associated marker 3-nitrotyrosine evade central tolerance and elicit a robust cell-mediated immune response. J Immunol 171(2): 528.

Bolwell, G. P. (1999). Role of active oxygen species and NO in plant defence responses. Curr Opin Plant Biol 2(4): 287.

Bowie, J. U., Luthy, R. y Eisenberg, D. (1991). A method to identify protein sequences that fold into a known three-dimensional structure. Science 253(5016): 164.

Bowler, C., Neuhaus, G., Yamagata, H. y Chua, N. H. (1994a). Cyclic GMP and calcium mediate phytochrome phototransduction. Cell 77(1): 73.

Bowler, C., Yamagata, H., Neuhaus, G. y Chua, N. H. (1994b). Phytochrome signal transduction pathways are regulated by reciprocal control mechanisms. Genes Dev 8(18): 2188.

Bredt, D. S., Hwang, P. M. y Snyder, S. H. (1990). Localization of nitric oxide synthase indicating a neural role for nitric oxide. Nature 347(6295): 768.

Bredt, D. S. y Snyder, S. H. (1990). Isolation of nitric oxide synthetase, a calmodulin-requiring enzyme. Proc Natl Acad Sci U S A 87(2): 682.

Bremer, D. J. (2006). Nitrous oxide fluxes in turfgrass: effects of nitrogen fertilization rates and types. J Environ Qual 35(5): 1678.

Brennan, M. L., Wu, W., Fu, X., Shen, Z., Song, W., Frost, H., Vadseth, C., Narine, L., Lenkiewicz, E., Borchers, M. T., Lusis, A. J., Lee, J. J., Lee, N. A., Abu-Soud, H. M., Ischiropoulos, H. y Hazen, S. L. (2002). A tale of two controversies: defining both the role of peroxidases in nitrotyrosine formation in vivo using eosinophil peroxidase and myeloperoxidase-deficient mice, and the nature of peroxidase-generated reactive nitrogen species. J Biol Chem 277(20): 17415.

Bright, J., Desikan, R., Hancock, J. T., Weir, I. S. y Neill, S. J. (2006). ABA-induced NO generation and stomatal closure in Arabidopsis are dependent on H2O2 synthesis. Plant J 45(1): 113.

Brouwer, M., Chamulitrat, W., Ferruzzi, G., Sauls, D. L. y Weinberg, J. B. (1996). Nitric oxide interactions with cobalamins: biochemical and functional consequences. Blood 88(5): 1857.

Bruckdorfer, R. (2005). The basics about nitric oxide. Mol Aspects Med 26(1-2): 3.

Brudler, R., Hitomi, K., Daiyasu, H., Toh, H., Kucho, K., Ishiura, M., Kanehisa, M., Roberts, V. A., Todo, T., Tainer, J. A. y Getzoff, E. D. (2003). Identification of a new cryptochrome class. Structure, function, and evolution. Mol Cell 11(1): 59.

Brychkova, G., Alikulov, Z., Fluhr, R. y Sagi, M. (2008). A critical role for ureides in dark and senescence-induced purine remobilization is unmasked in the Atxdh1 Arabidopsis mutant. Plant J 54(3): 496.

Buchanan, B., Gruissem, W. y Jones, R., Eds. (2000). Biochemistry \& Molecular Biology of Plants. Rockville, MD, John Wiley \& Sons Ltd.

Buchczyk, D. P., Briviba, K., Hartl, F. U. y Sies, H. (2000). Responses to peroxynitrite in yeast: glyceraldehyde-3-phosphate dehydrogenase (GAPDH) as a sensitive intracellular target for nitration and enhancement of chaperone expression and ubiquitination. Biol Chem 381(2): 121.

Butt, Y. K., Lum, J. H. y Lo, S. C. (2003). Proteomic identification of plant proteins probed by mammalian nitric oxide synthase antibodies. Planta 216(5): 762.

Campbell, W. H. (1999). NITRATE REDUCTASE STRUCTURE, FUNCTION AND REGULATION: Bridging the Gap between Biochemistry and Physiology. Annu Rev Plant Physiol Plant Mol Biol 50: 277. 
Caro, A. y Puntarulo, S. (1999). Nitric oxide generation by soybean embryonic axes. Possible effect on mitochondrial function. Free Radic Res 31 Suppl: S205.

Carol, R. J., Takeda, S., Linstead, P., Durrant, M. C., Kakesova, H., Derbyshire, P., Drea, S., Zarsky, V. y Dolan, L. (2005). A RhoGDP dissociation inhibitor spatially regulates growth in root hair cells. Nature 438(7070): 1013 .

Casoni, F., Basso, M., Massignan, T., Gianazza, E., Cheroni, C., Salmona, M., Bendotti, C. y Bonetto, V. (2005). Protein nitration in a mouse model of familial amyotrophic lateral sclerosis: possible multifunctional role in the pathogenesis. J Biol Chem 280(16): 16295.

Castillon, A., Shen, H. y Huq, E. (2007). Phytochrome Interacting Factors: central players in phytochromemediated light signaling networks. Trends Plant Sci 12(11): 514.

Cecconi, D., Orzetti, S., Vandelle, E., Rinalducci, S., Zolla, L. y Delledonne, M. (2009). Protein nitration during defense response in Arabidopsis thaliana. Electrophoresis 30(14): 2460.

Clack, T., Mathews, S. y Sharrock, R. A. (1994). The phytochrome apoprotein family in Arabidopsis is encoded by five genes: the sequences and expression of PHYD and PHYE. Plant Mol Biol 25(3): 413.

Clarke, A., Desikan, R., Hurst, R. D., Hancock, J. T. y Neill, S. J. (2000). NO way back: nitric oxide and programmed cell death in Arabidopsis thaliana suspension cultures. Plant J 24(5): 667.

Cluis, C. P., Mouchel, C. F. y Hardtke, C. S. (2004). The Arabidopsis transcription factor HY5 integrates light and hormone signaling pathways. Plant J 38(2): 332.

Conrad, R. (1996). Soil microorganisms as controllers of atmospheric trace gases (H2, CO, CH4, OCS, N2O, and NO). Microbiol Rev 60(4): 609.

Cooney, R. V., Harwood, P. J., Custer, L. J. y Franke, A. A. (1994). Light-mediated conversion of nitrogen dioxide to nitric oxide by carotenoids. Environ Health Perspect 102(5): 460.

Corpas, F. J., Barroso, J. B. y del Rio, L. A. (2001). Peroxisomes as a source of reactive oxygen species and nitric oxide signal molecules in plant cells. Trends Plant Sci 6(4): 145.

Corpas, F. J., Chaki, M., Fernandez-Ocana, A., Valderrama, R., Palma, J. M., Carreras, A., BegaraMorales, J. C., Airaki, M., del Rio, L. A. y Barroso, J. B. (2008). Metabolism of reactive nitrogen species in pea plants under abiotic stress conditions. Plant Cell Physiol 49(11): 1711.

Corpas, F. J., Chaki, M., Leterrier, M. y Barroso, J. B. (2009). Protein tyrosine nitration: a new challenge in plants. Plant Signal Behav 4(10): 920.

Corpas, F. J., del Rio, L. A. y Barroso, J. B. (2007). Need of biomarkers of nitrosative stress in plants. Trends Plant Sci 12(10): 436.

Correa-Aragunde, N., Graziano, M., Chevalier, C. y Lamattina, L. (2006). Nitric oxide modulates the expression of cell cycle regulatory genes during lateral root formation in tomato. J Exp Bot 57(3): 581.

Cousson, A. (2001). Pharmacological evidence for the implication of both cyclic GMP-dependent and independent transduction pathways within auxin-induced stomatal opening in Commelina communis (L.). Plant Sci 161(2): 249.

Cowling, R. J., Kamiya, Y., Seto, H. y Harberd, N. P. (1998). Gibberellin dose-response regulation of GA4 gene transcript levels in Arabidopsis. Plant Physiol 117(4): 1195.

Crawford, N. M., Galli, M., Tischner, R., Heimer, Y. M., Okamoto, M. y Mack, A. (2006). Response to Zemojtel et al: Plant nitric oxide synthase: back to square one Trends in Plant Science 11(11): 526.

Crow, J. P. y Beckman, J. S. (1995). The role of peroxynitrite in nitric oxide-mediated toxicity. Curr Top Microbiol Immunol 196: 57. 
Curry-McCoy, T. V., Osna, N. A. y Donohue, T. M., Jr. (2009). Modulation of lysozyme function and degradation after nitration with peroxynitrite. Biochim Biophys Acta 1790(8): 778.

Cutler, A. J. y Krochko, J. E. (1999). Formation and breakdown of ABA. Trends Plant Sci 4(12): 472.

Cutler, S. R., Rodriguez, P. L., Finkelstein, R. R. y Abrams, S. R. (2010). Abscisic acid: emergence of a core signaling network. Annu Rev Plant Biol 61: 651.

Chaki, M., Fernandez-Ocana, A. M., Valderrama, R., Carreras, A., Esteban, F. J., Luque, F., GomezRodriguez, M. V., Begara-Morales, J. C., Corpas, F. J. y Barroso, J. B. (2009a). Involvement of reactive nitrogen and oxygen species (RNS and ROS) in sunflower-mildew interaction. Plant Cell Physiol 50(2): 265.

Chaki, M., Valderrama, R., Fernandez-Ocana, A. M., Carreras, A., Lopez-Jaramillo, J., Luque, F., Palma, J. M., Pedrajas, J. R., Begara-Morales, J. C., Sanchez-Calvo, B., Gomez-Rodriguez, M. V., Corpas, F. J. y Barroso, J. B. (2009b). Protein targets of tyrosine nitration in sunflower (Helianthus annuus L.) hypocotyls. J Exp Bot 60(15): 4221.

Chandok, M. R., Ekengren, S. K., Martin, G. B. y Klessig, D. F. (2004). Suppression of pathogeninducible NO synthase (iNOS) activity in tomato increases susceptibility to Pseudomonas syringae. Proc Natl Acad Sci U S A 101(21): 8239.

Chandok, M. R., Ytterberg, A. J., van Wijk, K. J. y Klessig, D. F. (2003). The pathogen-inducible nitric oxide synthase (iNOS) in plants is a variant of the $\mathrm{P}$ protein of the glycine decarboxylase complex. Cell 113(4): 469.

Chang, G. G. y Huang, T. M. (1980). Involvement of tyrosyl residues in the substrate binding of pigeon liver malic enzyme. Biochim Biophys Acta 611(2): 217.

Chaves, M. M., Flexas, J. y Pinheiro, C. (2009). Photosynthesis under drought and salt stress: regulation mechanisms from whole plant to cell. Ann Bot 103(4): 551.

Chehab, E. W., Eich, E. y Braam, J. (2009). Thigmomorphogenesis: a complex plant response to mechano-stimulation. J Exp Bot 60(1): 43.

Chen, H., Zhang, J., Neff, M. M., Hong, S. W., Zhang, H., Deng, X. W. y Xiong, L. (2008a). Integration of light and abscisic acid signaling during seed germination and early seedling development. Proc Natl Acad Sci U S A 105(11): 4495.

Chen, H. J., Chang, C. M., Lin, W. P., Cheng, D. L. y Leong, M. I. (2008b). H2O2/nitrite-induced posttranslational modifications of human hemoglobin determined by mass spectrometry: redox regulation of tyrosine nitration and 3-nitrotyrosine reduction by antioxidants. Chembiochem 9(2): 312.

Chen, M., Galvao, R. M., Li, M., Burger, B., Bugea, J., Bolado, J. y Chory, J. (2010a). Arabidopsis HEMERA/pTAC12 initiates photomorphogenesis by phytochromes. Cell 141(7): 1230.

Chen, W. W., Yang, J. L., Qin, C., Jin, C. W., Mo, J. H., Ye, T. y Zheng, S. J. (2010b). Nitric oxide acts downstream of auxin to trigger root ferric-chelate reductase activity in response to iron deficiency in Arabidopsis. Plant Physiol 154(2): 810.

Chen, Y. L., Huang, R., Xiao, Y. M., Lu, P., Chen, J. y Wang, X. C. (2004). Extracellular calmodulininduced stomatal closure is mediated by heterotrimeric G protein and H2O2. Plant Physiol 136(4): 4096.

Chiang, H. H., Hwang, I. y Goodman, H. M. (1995). Isolation of the Arabidopsis GA4 locus. Plant Cell 7(2): 195.

Christie, J. M. y Briggs, W. R. (2001). Blue light sensing in higher plants. J Biol Chem 276(15): 11457. 
Christie, J. M., Reymond, P., Powell, G. K., Bernasconi, P., Raibekas, A. A., Liscum, E. y Briggs, W. R. (1998). Arabidopsis NPH1: a flavoprotein with the properties of a photoreceptor for phototropism. Science 282(5394): 1698 .

Dangl, J. (1998). Innate immunity. Plants just say NO to pathogens. Nature 394(6693): 525.

Danishpajooh, I. O., Gudi, T., Chen, Y., Kharitonov, V. G., Sharma, V. S. y Boss, G. R. (2001). Nitric oxide inhibits methionine synthase activity in vivo and disrupts carbon flow through the folate pathway. $\mathbf{J}$ Biol Chem 276(29): 27296.

de Lucas, M., Daviere, J. M., Rodriguez-Falcon, M., Pontin, M., Iglesias-Pedraz, J. M., Lorrain, S., Fankhauser, C., Blazquez, M. A., Titarenko, E. y Prat, S. (2008). A molecular framework for light and gibberellin control of cell elongation. Nature 451(7177): 480.

Dean, J. y Harper, J. (1986). Nitric Oxide and Nitrous Oxide Production by Soybean and Winged Bean during the in Vivo Nitrate Reductase Assay. Plant Physiol 82(3): 718.

Dean, J. V. y Harper, J. E. (1988). The Conversion of Nitrite to Nitrogen Oxide(s) by the Constitutive NAD(P)H-Nitrate Reductase Enzyme from Soybean. Plant Physiol 88(2): 389.

del Rio, L. A., Corpas, F. J. y Barroso, J. B. (2004). Nitric oxide and nitric oxide synthase activity in plants. Phytochemistry 65(7): 783.

del Rio, L. A., Corpas, F. J., Sandalio, L. M., Palma, J. M., Gomez, M. y Barroso, J. B. (2002). Reactive oxygen species, antioxidant systems and nitric oxide in peroxisomes. J Exp Bot 53(372): 1255.

Delledonne, M., Xia, Y., Dixon, R. A. y Lamb, C. (1998). Nitric oxide functions as a signal in plant disease resistance. Nature 394(6693): 585.

Delledonne, M., Zeier, J., Marocco, A. y Lamb, C. (2001). Signal interactions between nitric oxide and reactive oxygen intermediates in the plant hypersensitive disease resistance response. Proc Natl Acad Sci $\mathbf{U}$ S A 98(23): 13454.

Deng, X. W., Caspar, T. y Quail, P. H. (1991). cop1: a regulatory locus involved in light-controlled development and gene expression in Arabidopsis. Genes Dev 5(7): 1172.

Desikan, R., Cheung, M. K., Bright, J., Henson, D., Hancock, J. T. y Neill, S. J. (2004). ABA, hydrogen peroxide and nitric oxide signalling in stomatal guard cells. J Exp Bot 55(395): 205.

Desikan, R., Griffiths, R., Hancock, J. y Neill, S. (2002). A new role for an old enzyme: nitrate reductasemediated nitric oxide generation is required for abscisic acid-induced stomatal closure in Arabidopsis thaliana. Proc Natl Acad Sci U S A 99(25): 16314.

Diaz, M., Achkor, H., Titarenko, E. y Martinez, M. C. (2003). The gene encoding glutathione-dependent formaldehyde dehydrogenase/GSNO reductase is responsive to wounding, jasmonic acid and salicylic acid. FEBS Lett 543(1-3): 136.

DiCola, D., Polidoro, G., Di Ilio, G., Del Boccia, C., Politi, L. y Scandurra, R. (1976). Role of tyrosine residues in cytoplasmic aspartate aminotransferase from beef kidney. Mol Cell Biochem 11(2): 97.

Dietz, K. J., Sauter, A., Wichert, K., Messdaghi, D. y Hartung, W. (2000). Extracellular beta-glucosidase activity in barley involved in the hydrolysis of ABA glucose conjugate in leaves. J Exp Bot 51(346): 937.

Dill, A., Thomas, S. G., Hu, J., Steber, C. M. y Sun, T. P. (2004). The Arabidopsis F-box protein SLEEPY1 targets gibberellin signaling repressors for gibberellin-induced degradation. Plant Cell 16(6): 1392. 
Dodd, A. N., Gardner, M. J., Hotta, C. T., Hubbard, K. E., Dalchau, N., Love, J., Assie, J. M., Robertson, F. C., Jakobsen, M. K., Goncalves, J., Sanders, D. y Webb, A. A. (2007). The Arabidopsis circadian clock incorporates a cADPR-based feedback loop. Science 318(5857): 1789.

Dubovskaya, L. V., Bakakina, Y. S., Kolesneva, E. V., Sodel, D. L., McAinsh, M. R., Hetherington, A. M. y Volotovski, I. D. (2011). cGMP-dependent ABA-induced stomatal closure in the ABA-insensitive Arabidopsis mutant abil-1. New Phytol.

Duek, P. D. y Fankhauser, C. (2003). HFR1, a putative bHLH transcription factor, mediates both phytochrome A and cryptochrome signalling. Plant J 34(6): 827.

Dupeux, F., Antoni, R., Betz, K., Santiago, J., Gonzalez-Guzman, M., Rodriguez, L., Rubio, S., Park, S. Y., Cutler, S., Rodriguez, P. L. y Marquez, J. (2011). Modulation of ABA signaling in vivo by an engineered receptor-insensitive PP2C allele. Plant Physiol.

Durner, J. y Klessig, D. F. (1999). Nitric oxide as a signal in plants. Curr Opin Plant Biol 2(5): 369.

Elfering, S. L., Haynes, V. L., Traaseth, N. J., Ettl, A. y Giulivi, C. (2004). Aspects, mechanism, and biological relevance of mitochondrial protein nitration sustained by mitochondrial nitric oxide synthase. Am J Physiol Heart Circ Physiol 286(1): H22.

Espunya, M. C., Diaz, M., Moreno-Romero, J. y Martinez, M. C. (2006). Modification of intracellular levels of glutathione-dependent formaldehyde dehydrogenase alters glutathione homeostasis and root development. Plant Cell Environ 29(5): 1002.

Fairchild, C. D., Schumaker, M. A. y Quail, P. H. (2000). HFR1 encodes an atypical bHLH protein that acts in phytochrome A signal transduction. Genes Dev 14(18): 2377.

Feng, S., Martinez, C., Gusmaroli, G., Wang, Y., Zhou, J., Wang, F., Chen, L., Yu, L., Iglesias-Pedraz, J. M., Kircher, S., Schafer, E., Fu, X., Fan, L. M. y Deng, X. W. (2008). Coordinated regulation of Arabidopsis thaliana development by light and gibberellins. Nature 451(7177): 475.

Ferrandiz, C., Pelaz, S. y Yanofsky, M. F. (1999). Control of carpel and fruit development in Arabidopsis. Annu Rev Biochem 68: 321.

Finch-Savage, W. E., Cadman, C. S., Toorop, P. E., Lynn, J. R. y Hilhorst, H. W. (2007). Seed dormancy release in Arabidopsis Cvi by dry after-ripening, low temperature, nitrate and light shows common quantitative patterns of gene expression directed by environmentally specific sensing. Plant $\mathbf{J}$ 51(1): 60 .

Finch-Savage, W. E. y Leubner-Metzger, G. (2006). Seed dormancy and the control of germination. New Phytol 171(3): 501.

Finkelstein, R., Reeves, W., Ariizumi, T. y Steber, C. (2008). Molecular aspects of seed dormancy. Annu Rev Plant Biol 59: 387.

Fiore, G., Di Cristo, C., Monti, G., Amoresano, A., Columbano, L., Pucci, P., Cioffi, F. A., Di Cosmo, A., Palumbo, A. y d'Ischia, M. (2006). Tubulin nitration in human gliomas. Neurosci Lett 394(1): 57.

Fischer, E. y Krebs, E. (1966). Relationship of structure to function of muscle phosphorylase. Fed Proc 25(5): 1511.

Flores-Perez, U., Sauret-Gueto, S., Gas, E., Jarvis, P. y Rodriguez-Concepcion, M. (2008). A mutant impaired in the production of plastome-encoded proteins uncovers a mechanism for the homeostasis of isoprenoid biosynthetic enzymes in Arabidopsis plastids. Plant Cell 20(5): 1303.

Flores, T., Todd, C. D., Tovar-Mendez, A., Dhanoa, P. K., Correa-Aragunde, N., Hoyos, M. E., Brownfield, D. M., Mullen, R. T., Lamattina, L. y Polacco, J. C. (2008). Arginase-negative mutants of Arabidopsis exhibit increased nitric oxide signaling in root development. Plant Physiol 147(4): 1936. 
Floris, R., Piersma, S. R., Yang, G., Jones, P. y Wever, R. (1993). Interaction of myeloperoxidase with peroxynitrite. A comparison with lactoperoxidase, horseradish peroxidase and catalase. Eur J Biochem 215(3): 767.

Floryszak-Wieczorek, J., Milczarek, G., Arasimowicz, M. y Ciszewski, A. (2006). Do nitric oxide donors mimic endogenous NO-related response in plants? Planta 224(6): 1363.

Folta, K. M. y Maruhnich, S. A. (2007). Green light: a signal to slow down or stop. J Exp Bot 58(12): 3099.

Foreman, J., Demidchik, V., Bothwell, J. H., Mylona, P., Miedema, H., Torres, M. A., Linstead, P., Costa, S., Brownlee, C., Jones, J. D., Davies, J. M. y Dolan, L. (2003). Reactive oxygen species produced by NADPH oxidase regulate plant cell growth. Nature 422(6930): 442.

Franze, T., Weller, M. G., Niessner, R. y Poschl, U. (2004). Comparison of nitrotyrosine antibodies and development of immunoassays for the detection of nitrated proteins. Analyst 129(7): 589.

Frigerio, M., Alabadi, D., Perez-Gomez, J., Garcia-Carcel, L., Phillips, A. L., Hedden, P. y Blazquez, M. A. (2006). Transcriptional regulation of gibberellin metabolism genes by auxin signaling in Arabidopsis. Plant Physiol 142(2): 553.

Fu, X., Richards, D. E., Fleck, B., Xie, D., Burton, N. y Harberd, N. P. (2004). The Arabidopsis mutant sleepylgar2-1 protein promotes plant growth by increasing the affinity of the SCFSLY1 E3 ubiquitin ligase for DELLA protein substrates. Plant Cell 16(6): 1406.

Fujii, H., Chinnusamy, V., Rodrigues, A., Rubio, S., Antoni, R., Park, S. Y., Cutler, S. R., Sheen, J., Rodriguez, P. L. y Zhu, J. K. (2009). In vitro reconstitution of an abscisic acid signalling pathway. Nature 462(7273): 660 .

Fujisawa, Y., Kato, K. y Giulivi, C. (2009). Nitration of tyrosine residues 368 and 345 in the beta-subunit elicits FoF1-ATPase activity loss. Biochem J 423(2): 219.

Fujita, H., Morisugi, T., Tanaka, Y., Kawakami, T., Kirita, T. y Yoshimura, Y. (2009). MMP-3 activation is a hallmark indicating an early change in TMJ disorders, and is related to nitration. Int J Oral Maxillofac Surg 38(1): 70.

Gallego-Bartolome, J., Minguet, E. G., Marin, J. A., Prat, S., Blazquez, M. A. y Alabadi, D. (2010). Transcriptional diversification and functional conservation between DELLA proteins in Arabidopsis. Mol Biol Evol 27(6): 1247

Gao, Y., Zeng, Q., Guo, J., Cheng, J., Ellis, B. E. y Chen, J. G. (2007). Genetic characterization reveals no role for the reported ABA receptor, GCR2, in ABA control of seed germination and early seedling development in Arabidopsis. Plant J 52(6): 1001.

Gapper, C. y Dolan, L. (2006). Control of plant development by reactive oxygen species. Plant Physiol 141(2): 341 .

Garcia-Mata, C. y Lamattina, L. (2001). Nitric oxide induces stomatal closure and enhances the adaptive plant responses against drought stress. Plant Physiol 126(3): 1196.

Garcia-Mata, C. y Lamattina, L. (2002). Nitric oxide and abscisic acid cross talk in guard cells. Plant Physiol 128(3): 790.

Garcia-Mata, C. y Lamattina, L. (2007). Abscisic acid (ABA) inhibits light-induced stomatal opening through calcium- and nitric oxide-mediated signaling pathways. Nitric Oxide 17(3-4): 143.

Gas, E., Flores-Perez, U., Sauret-Gueto, S. y Rodriguez-Concepcion, M. (2009). Hunting for plant nitric oxide synthase provides new evidence of a central role for plastids in nitric oxide metabolism. Plant Cell 21(1): 18 . 
Gaupels, F., Spiazzi-Vandelle, E., Yang, D. y Delledonne, M. (2011). Detection of peroxynitrite accumulation in Arabidopsis thaliana during the hypersensitive defense response. Nitric Oxide.

Gemes, K., Poor, P., Horvath, E., Kolbert, Z., Szopko, D., Szepesi, A. y Tari, I. (2011). Cross-talk between salicylic acid and $\mathrm{NaCl}$-generated reactive oxygen species and nitric oxide in tomato during acclimation to high salinity. Physiol Plant.

Ghesquiere, B., Colaert, N., Helsens, K., Dejager, L., Vanhaute, C., Verleysen, K., Kas, K., Timmerman, E., Goethals, M., Libert, C., Vandekerckhove, J. y Gevaert, K. (2009). In vitro and in vivo protein-bound tyrosine nitration characterized by diagonal chromatography. Mol Cell Proteomics 8(12): 2642.

Ghosh, S., Janocha, A. J., Aronica, M. A., Swaidani, S., Comhair, S. A., Xu, W., Zheng, L., Kaveti, S., Kinter, M., Hazen, S. L. y Erzurum, S. C. (2006). Nitrotyrosine proteome survey in asthma identifies oxidative mechanism of catalase inactivation. J Immunol 176(9): 5587.

Gilberthorpe, N. J. y Poole, R. K. (2008). Nitric oxide homeostasis in Salmonella typhimurium: roles of respiratory nitrate reductase and flavohemoglobin. J Biol Chem 283(17): 11146.

Gniazdowska, A., Dobrzynska, U., Babanczyk, T. y Bogatek, R. (2007). Breaking the apple embryo dormancy by nitric oxide involves the stimulation of ethylene production. Planta 225(4): 1051.

Godber, B. L., Doel, J. J., Durgan, J., Eisenthal, R. y Harrison, R. (2000a). A new route to peroxynitrite: a role for xanthine oxidoreductase. FEBS Lett 475(2): 93.

Godber, B. L., Doel, J. J., Sapkota, G. P., Blake, D. R., Stevens, C. R., Eisenthal, R. y Harrison, R. (2000b). Reduction of nitrite to nitric oxide catalyzed by xanthine oxidoreductase. J Biol Chem 275(11): 7757.

Gokulrangan, G., Zaidi, A., Michaelis, M. L. y Schoneich, C. (2007). Proteomic analysis of protein nitration in rat cerebellum: effect of biological aging. J Neurochem 100(6): 1494.

Gole, M. D., Souza, J. M., Choi, I., Hertkorn, C., Malcolm, S., Foust, R. F., 3rd, Finkel, B., Lanken, P. N. y Ischiropoulos, H. (2000). Plasma proteins modified by tyrosine nitration in acute respiratory distress syndrome. Am J Physiol Lung Cell Mol Physiol 278(5): L961.

Gonzalez-Garcia, M. P., Vilarrasa-Blasi, J., Zhiponova, M., Divol, F., Mora-Garcia, S., Russinova, E. y Cano-Delgado, A. I. (2011). Brassinosteroids control meristem size by promoting cell cycle progression in Arabidopsis roots. Development 138(5): 849.

Gonzalez-Guzman, M., Apostolova, N., Belles, J. M., Barrero, J. M., Piqueras, P., Ponce, M. R., Micol, J. L., Serrano, R. y Rodriguez, P. L. (2002). The short-chain alcohol dehydrogenase ABA2 catalyzes the conversion of xanthoxin to abscisic aldehyde. Plant Cell 14(8): 1833.

Gorg, B., Bidmon, H. J., Keitel, V., Foster, N., Goerlich, R., Schliess, F. y Haussinger, D. (2006). Inflammatory cytokines induce protein tyrosine nitration in rat astrocytes. Arch Biochem Biophys 449(1-2): 104.

Gosti, F., Beaudoin, N., Serizet, C., Webb, A. A., Vartanian, N. y Giraudat, J. (1999). ABI1 protein phosphatase $2 \mathrm{C}$ is a negative regulator of abscisic acid signaling. Plant Cell 11(10): 1897.

Gow, A., Duran, D., Thom, S. R. y Ischiropoulos, H. (1996). Carbon dioxide enhancement of peroxynitrite-mediated protein tyrosine nitration. Arch Biochem Biophys 333(1): 42.

Gow, A. J., Farkouh, C. R., Munson, D. A., Posencheg, M. A. y Ischiropoulos, H. (2004). Biological significance of nitric oxide-mediated protein modifications. Am J Physiol Lung Cell Mol Physiol 287(2): L262.

Gow, A. J. y Stamler, J. S. (1998). Reactions between nitric oxide and haemoglobin under physiological conditions. Nature 391(6663): 169. 
Graham, I. A. (2008). Seed storage oil mobilization. Annu Rev Plant Biol 59: 115.

Graziano, M. y Lamattina, L. (2007). Nitric oxide accumulation is required for molecular and physiological responses to iron deficiency in tomato roots. Plant J 52(5): 949.

Griffiths, J., Murase, K., Rieu, I., Zentella, R., Zhang, Z. L., Powers, S. J., Gong, F., Phillips, A. L., Hedden, P., Sun, T. P. y Thomas, S. G. (2006). Genetic characterization and functional analysis of the GID1 gibberellin receptors in Arabidopsis. Plant Cell 18(12): 3399.

Groppa, M. D., Rosales, E. P., Iannone, M. F. y Benavides, M. P. (2008). Nitric oxide, polyamines and Cd-induced phytotoxicity in wheat roots. Phytochemistry 69(14): 2609.

Grubisic, D., Giba, Z. y Konjevic, R. (1992). The effect of organic nitrates in phytochrome-controlled germination of Paulownia tomentosa seeds. Photochem Photobiol(56): 629.

Gubler, F., Millar, A. A. y Jacobsen, J. V. (2005). Dormancy release, ABA and pre-harvest sprouting. Curr Opin Plant Biol 8(2): 183.

Guo, F. Q. y Crawford, N. M. (2005). Arabidopsis nitric oxide synthase1 is targeted to mitochondria and protects against oxidative damage and dark-induced senescence. Plant Cell 17(12): 3436.

Guo, F. Q., Okamoto, M. y Crawford, N. M. (2003). Identification of a plant nitric oxide synthase gene involved in hormonal signaling. Science 302(5642): 100.

Guo, J., Zeng, Q., Emami, M., Ellis, B. E. y Chen, J. G. (2008). The GCR2 gene family is not required for ABA control of seed germination and early seedling development in Arabidopsis. PLoS One 3(8): e2982.

Gupta, K. J. (2011). Protein S-nitrosylation in plants: photorespiratory metabolism and NO signaling. Sci Signal 4(154): jc1.

Gupta, K. J., Fernie, A. R., Kaiser, W. M. y van Dongen, J. T. (2011). On the origins of nitric oxide. Trends Plant Sci 16(3): 160.

Gupta, K. J., Stoimenova, M. y Kaiser, W. M. (2005). In higher plants, only root mitochondria, but not leaf mitochondria reduce nitrite to NO, in vitro and in situ. J Exp Bot 56(420): 2601.

Han, S., Tang, R., Anderson, L. K., Woerner, T. E. y Pei, Z. M. (2003). A cell surface receptor mediates extracellular $\mathrm{Ca}(2+)$ sensing in guard cells. Nature 425(6954): 196.

Harberd, N., Ed. (2006). Seed to seed: The secret life of plants. London, Bloomsbury publishing.

Harberd, N. P. (2003). Botany. Relieving DELLA restraint. Science 299(5614): 1853.

Harberd, N. P., Belfield, E. y Yasumura, Y. (2009). The angiosperm gibberellin-GID1-DELLA growth regulatory mechanism: how an "inhibitor of an inhibitor" enables flexible response to fluctuating environments. Plant Cell 21(5): 1328.

Harper, J. E. (1981). Evolution of Nitrogen Oxide(s) during In Vivo Nitrate Reductase Assay of Soybean Leaves. Plant Physiol 68(6): 1488.

Harrison, R. (2002). Structure and function of xanthine oxidoreductase: where are we now? Free Radic Biol Med 33(6): 774.

Hartung, W., Sauter, A. y Hose, E. (2002). Abscisic acid in the xylem: where does it come from, where does it go to? J Exp Bot 53(366): 27.

He, Y., Tang, R. H., Hao, Y., Stevens, R. D., Cook, C. W., Ahn, S. M., Jing, L., Yang, Z., Chen, L., Guo, F., Fiorani, F., Jackson, R. B., Crawford, N. M. y Pei, Z. M. (2004). Nitric oxide represses the Arabidopsis floral transition. Science 305(5692): 1968. 
Heim, M. A., Jakoby, M., Werber, M., Martin, C., Weisshaar, B. y Bailey, P. C. (2003). The basic helixloop-helix transcription factor family in plants: a genome-wide study of protein structure and functional diversity. Mol Biol Evol 20(5): 735.

Hesberg, C., Hansch, R., Mendel, R. R. y Bittner, F. (2004). Tandem orientation of duplicated xanthine dehydrogenase genes from Arabidopsis thaliana: differential gene expression and enzyme activities. J Biol Chem 279(14): 13547.

Hilhorst, H. W. (1990a). Dose-Response Analysis of Factors Involved in Germination and Secondary Dormancy of Seeds of Sisymbrium officinale: I. Phytochrome. Plant Physiol 94(3): 1090.

Hilhorst, H. W. (1990b). Dose-Response Analysis of Factors Involved in Germination and Secondary Dormancy of Seeds of Sisymbrium officinale: II. Nitrate. Plant Physiol 94(3): 1096.

Hiltbrunner, A., Tscheuschler, A., Viczian, A., Kunkel, T., Kircher, S. y Schafer, E. (2006). FHY1 and FHL act together to mediate nuclear accumulation of the phytochrome A photoreceptor. Plant Cell Physiol 47(8): 1023 .

Hiltbrunner, A., Viczian, A., Bury, E., Tscheuschler, A., Kircher, S., Toth, R., Honsberger, A., Nagy, F., Fankhauser, C. y Schafer, E. (2005). Nuclear accumulation of the phytochrome A photoreceptor requires FHY1. Curr Biol 15(23): 2125.

Ho, C. H., Lin, S. H., Hu, H. C. y Tsay, Y. F. (2009). CHL1 functions as a nitrate sensor in plants. Cell 138(6): 1184.

Holdsworth, M. J., Bentsink, L. y Soppe, W. J. (2008a). Molecular networks regulating Arabidopsis seed maturation, after-ripening, dormancy and germination. New Phytol 179(1): 33.

Holdsworth, M. J., Finch-Savage, W. E., Grappin, P. y Job, D. (2008b). Post-genomics dissection of seed dormancy and germination. Trends Plant Sci 13(1): 7.

Holtgrefe, S., Gohlke, J., Starmann, J., Druce, S., Klocke, S., Altmann, B., Wojtera, J., Lindermayr, C. y Scheibe, R. (2008). Regulation of plant cytosolic glyceraldehyde 3-phosphate dehydrogenase isoforms by thiol modifications. Physiol Plant 133(2): 211.

Hong, J. K., Yun, B. W., Kang, J. G., Raja, M. U., Kwon, E., Sorhagen, K., Chu, C., Wang, Y. y Loake, G. J. (2008). Nitric oxide function and signalling in plant disease resistance. J Exp Bot 59(2): 147.

Hong, S. J., Gokulrangan, G. y Schoneich, C. (2007). Proteomic analysis of age dependent nitration of rat cardiac proteins by solution isoelectric focusing coupled to nanoHPLC tandem mass spectrometry. Exp Gerontol 42(7): 639.

Horiguchi, G., Ferjani, A., Fujikura, U. y Tsukaya, H. (2006). Coordination of cell proliferation and cell expansion in the control of leaf size in Arabidopsis thaliana. J Plant Res 119(1): 37.

Hornitschek, P., Lorrain, S., Zoete, V., Michielin, O. y Fankhauser, C. (2009). Inhibition of the shade avoidance response by formation of non-DNA binding bHLH heterodimers. EMBO J 28(24): 3893.

Hu, X., Neill, S. J., Tang, Z. y Cai, W. (2005). Nitric oxide mediates gravitropic bending in soybean roots. Plant Physiol 137(2): 663.

Huang, S., Kerschbaum, H. H., Engel, E. y Hermann, A. (1997). Biochemical characterization and histochemical localization of nitric oxide synthase in the nervous system of the snail, Helix pomatia. $\mathbf{J}$ Neurochem 69(6): 2516.

Huang, X., Stettmaier, K., Michel, C., Hutzler, P., Mueller, M. J. y Durner, J. (2004). Nitric oxide is induced by wounding and influences jasmonic acid signaling in Arabidopsis thaliana. Planta 218(6): 938. 
Huang, X., von Rad, U. y Durner, J. (2002). Nitric oxide induces transcriptional activation of the nitric oxide-tolerant alternative oxidase in Arabidopsis suspension cells. Planta 215(6): 914.

Huang, Y., Baxter, R., Smith, B. S., Partch, C. L., Colbert, C. L. y Deisenhofer, J. (2006). Crystal structure of cryptochrome 3 from Arabidopsis thaliana and its implications for photolyase activity. Proc Natl Acad Sci U S A 103(47): 17701.

Huq, E. y Quail, P. H. (2002). PIF4, a phytochrome-interacting bHLH factor, functions as a negative regulator of phytochrome B signaling in Arabidopsis. EMBO J 21(10): 2441.

Igamberdiev, A. U. y Hill, R. D. (2009). Plant mitochondrial function during anaerobiosis. Ann Bot 103(2): 259.

Ignarro, L. J. (1990). Nitric oxide. A novel signal transduction mechanism for transcellular communication. Hypertension 16(5): 477.

Ikeda, A., Ueguchi-Tanaka, M., Sonoda, Y., Kitano, H., Koshioka, M., Futsuhara, Y., Matsuoka, M. y Yamaguchi, J. (2001). slender rice, a constitutive gibberellin response mutant, is caused by a null mutation of the SLR1 gene, an ortholog of the height-regulating gene GAI/RGA/RHT/D8. Plant Cell 13(5): 999.

Imaizumi, T., Tran, H. G., Swartz, T. E., Briggs, W. R. y Kay, S. A. (2003). FKF1 is essential for photoperiodic-specific light signalling in Arabidopsis. Nature 426(6964): 302.

Inoue, K., Akaike, T., Miyamoto, Y., Okamoto, T., Sawa, T., Otagiri, M., Suzuki, S., Yoshimura, T. y Maeda, H. (1999). Nitrosothiol formation catalyzed by ceruloplasmin. Implication for cytoprotective mechanism in vivo. J Biol Chem 274(38): 27069.

Irie, Y., Saeki, M., Kamisaki, Y., Martin, E. y Murad, F. (2003). Histone H1.2 is a substrate for denitrase, an activity that reduces nitrotyrosine immunoreactivity in proteins. Proc Natl Acad Sci U S A 100(10): 5634.

Ischiropoulos, H. (1998). Biological tyrosine nitration: a pathophysiological function of nitric oxide and reactive oxygen species. Arch Biochem Biophys 356(1): 1.

Ischiropoulos, H. (2003). Biological selectivity and functional aspects of protein tyrosine nitration. Biochem Biophys Res Commun 305(3): 776.

Ischiropoulos, H. y al-Mehdi, A. B. (1995). Peroxynitrite-mediated oxidative protein modifications. FEBS Lett 364(3): 279.

Ito, K., Hanazawa, T., Tomita, K., Barnes, P. J. y Adcock, I. M. (2004). Oxidative stress reduces histone deacetylase 2 activity and enhances IL-8 gene expression: role of tyrosine nitration. Biochem Biophys Res Commun 315(1): 240.

Jang, I. C., Henriques, R., Seo, H. S., Nagatani, A. y Chua, N. H. (2010). Arabidopsis PHYTOCHROME INTERACTING FACTOR proteins promote phytochrome B polyubiquitination by COP1 E3 ligase in the nucleus. Plant Cell 22(7): 2370.

Jang, I. C., Yang, J. Y., Seo, H. S. y Chua, N. H. (2005). HFR1 is targeted by COP1 E3 ligase for posttranslational proteolysis during phytochrome A signaling. Genes Dev 19(5): 593.

Jarillo, J. A., Capel, J., Tang, R. H., Yang, H. Q., Alonso, J. M., Ecker, J. R. y Cashmore, A. R. (2001a). An Arabidopsis circadian clock component interacts with both CRY1 and phyB. Nature 410(6827): 487.

Jarillo, J. A., Gabrys, H., Capel, J., Alonso, J. M., Ecker, J. R. y Cashmore, A. R. (2001b). Phototropinrelated NPL1 controls chloroplast relocation induced by blue light. Nature 410(6831): 952.

Jasid, S., Simontacchi, M., Bartoli, C. G. y Puntarulo, S. (2006). Chloroplasts as a nitric oxide cellular source. Effect of reactive nitrogen species on chloroplastic lipids and proteins. Plant Physiol 142(3): 1246. 
Jeannette, E., Rona, J. P., Bardat, F., Cornel, D., Sotta, B. y Miginiac, E. (1999). Induction of RAB 18 gene expression and activation of $\mathrm{K}+$ outward rectifying channels depend on an extracellular perception of ABA in Arabidopsis thaliana suspension cells. Plant J 18(1): 13.

Jenkins, G. I. (2009). Signal transduction in responses to UV-B radiation. Annu Rev Plant Biol 60: 407.

Jiao, Y., Lau, O. S. y Deng, X. W. (2007). Light-regulated transcriptional networks in higher plants. Nat Rev Genet 8(3): 217.

Jing, H. C., Hebeler, R., Oeljeklaus, S., Sitek, B., Stuhler, K., Meyer, H. E., Sturre, M. J., Hille, J., Warscheid, B. y Dijkwel, P. P. (2008). Early leaf senescence is associated with an altered cellular redox balance in Arabidopsis cpr5/old1 mutants. Plant Biol (Stuttg) 10 Suppl 1: 85.

Johansson, C. (1984). Field measurements of emission of nitric oxide from fertilized and unfertilized forest soils in Sweden Journal of Atmospheric Chemistry 1: 429.

Jonassen, E. M., Sandsmark, B. A. y Lillo, C. (2009a). Unique status of NIA2 in nitrate assimilation: NIA2 expression is promoted by HY5/HYH and inhibited by PIF4. Plant Signal Behav 4(11): 1084.

Jonassen, E. M., Sevin, D. C. y Lillo, C. (2009b). The bZIP transcription factors HY5 and HYH are positive regulators of the main nitrate reductase gene in Arabidopsis leaves, NIA2, but negative regulators of the nitrate uptake gene NRT1.1. J Plant Physiol 166(18): 2071.

Jovanovic, V., Giba, Z., Djokovic, D., Milosavljevic, S., Grubisic, D. y Konjevic, R. (2005). Gibberellic acid nitrite stimulates germination of two species of light-requiring seeds via the nitric oxide pathway. Ann N Y Acad Sci 1048: 476.

Kagawa, T., Kasahara, M., Abe, T., Yoshida, S. y Wada, M. (2004). Function analysis of phototropin2 using fern mutants deficient in blue light-induced chloroplast avoidance movement. Plant Cell Physiol 45(4): 416.

Kami, C., Lorrain, S., Hornitschek, P. y Fankhauser, C. (2010). Light-regulated plant growth and development. Curr Top Dev Biol 91: 29.

Kamisaki, Y., Wada, K., Bian, K., Balabanli, B., Davis, K., Martin, E., Behbod, F., Lee, Y. C. y Murad, F. (1998). An activity in rat tissues that modifies nitrotyrosine-containing proteins. Proc Natl Acad Sci U S A 95(20): 11584.

Kang, J., Hwang, J. U., Lee, M., Kim, Y. Y., Assmann, S. M., Martinoia, E. y Lee, Y. (2010). PDR-type $\mathrm{ABC}$ transporter mediates cellular uptake of the phytohormone abscisic acid. Proc Natl Acad Sci U S A 107(5): 2355.

Kasina, S., Rizwani, W., Radhika, K. V.y Singh, S. S. (2005). Nitration of profilin effects its interaction with poly (L-proline) and actin. J Biochem 138(6): 687.

Kato, H., Asai, S., Yamamoto-Katou, A., Yoshioka, H., Doke, N. y Kawakita, K. (2008). Involvement of NbNOA1 in NO production and defense responses in INF1-treated Nicotiana benthamiana.

JGenPlantPathol 74: 15.

Keeley, J. E. y Fotheringham, C. J. (1998). Mechanism of smoke-induced seed germination in a post-fire chaparral annual. Journal of Ecology 86: 27.

Khanna, R., Huq, E., Kikis, E. A., Al-Sady, B., Lanzatella, C. y Quail, P. H. (2004). A novel molecular recognition motif necessary for targeting photoactivated phytochrome signaling to specific basic helix-loophelix transcription factors. Plant Cell 16(11): 3033.

Kiba, T., Henriques, R., Sakakibara, H. y Chua, N. H. (2007). Targeted degradation of PSEUDORESPONSE REGULATOR5 by an SCFZTL complex regulates clock function and photomorphogenesis in Arabidopsis thaliana. Plant Cell 19(8): 2516. 
Kidokoro, S., Maruyama, K., Nakashima, K., Imura, Y., Narusaka, Y., Shinwari, Z. K., Osakabe, Y., Fujita, Y., Mizoi, J., Shinozaki, K. y Yamaguchi-Shinozaki, K. (2009). The phytochrome-interacting factor PIF7 negatively regulates DREB1 expression under circadian control in Arabidopsis. Plant Physiol 151(4): 2046.

Kim, J., Yi, H., Choi, G., Shin, B. y Song, P. S. (2003). Functional characterization of phytochrome interacting factor 3 in phytochrome-mediated light signal transduction. Plant Cell 15(10): 2399.

Kim, W. K. (1999). S-nitrosation ameliorates homocysteine-induced neurotoxicity and calcium responses in primary culture of rat cortical neurons. Neurosci Lett 265(2): 99.

Kim, W. K., Choi, Y. B., Rayudu, P. V., Das, P., Asaad, W., Arnelle, D. R., Stamler, J. S. y Lipton, S. A. (1999). Attenuation of NMDA receptor activity and neurotoxicity by nitroxyl anion, NO. Neuron 24(2): 461 .

Kiyosue, T. y Wada, M. (2000). LKP1 (LOV kelch protein 1): a factor involved in the regulation of flowering time in arabidopsis. Plant J 23(6): 807.

Kleine, T., Lockhart, P. y Batschauer, A. (2003). An Arabidopsis protein closely related to Synechocystis cryptochrome is targeted to organelles. Plant J 35(1): 93.

Klepper, L. (1990). Comparison between $\mathrm{NO}(\mathrm{x})$ Evolution Mechanisms of Wild-Type and nr(1) Mutant Soybean Leaves. Plant Physiol 93(1): 26.

Klepper, L. A. (1987). Nitric Oxide Emissions from Soybean Leaves during in Vivo Nitrate Reductase Assays. Plant Physiol 85(1): 96.

Klessig, D., Martin, G. y Ekengren, S. (2004a). Suppression of pathogen-inducible NO synthase (iNOS) activity in tomato increases susceptibility to Pseudomonas syringae. Proc Natl Acad Sci U S A 101(45).

Klessig, D. F., Ytterberg, A. J. y van Wijk, K. J. (2004b). The pathogen-inducible nitric oxide synthase (iNOS) in plants is a variant of the P protein of the glycine decarboxylase complex. Cell 119(3): 445.

Knowles, M. E., McWeeny, D. J., Couchman, L. y Thorogood, M. (1974). Interaction of nitrite with proteins at gastric pH. Nature 247(439): 288.

Knyushko, T. V., Sharov, V. S., Williams, T. D., Schoneich, C. y Bigelow, D. J. (2005). 3-Nitrotyrosine modification of SERCA2a in the aging heart: a distinct signature of the cellular redox environment. Biochemistry 44(39): 13071.

Koini, M. A., Alvey, L., Allen, T., Tilley, C. A., Harberd, N. P., Whitelam, G. C. y Franklin, K. A. (2009). High temperature-mediated adaptations in plant architecture require the bHLH transcription factor PIF4. Curr Biol 19(5): 408.

Kolbert, Z., Bartha, B. y Erdei, L. (2008a). Exogenous auxin-induced NO synthesis is nitrate reductaseassociated in Arabidopsis thaliana root primordia. J Plant Physiol 165(9): 967.

Kolbert, Z., Bartha, B. y Erdei, L. (2008b). Osmotic stress- and indole-3-butyric acid-induced NO generation are partially distinct processes in root growth and development in Pisum sativum. Physiol Plant 133(2): 406.

Kolbert, Z. y Erdei, L. (2008). Involvement of nitrate reductase in auxin-induced NO synthesis. Plant Signal Behav 3(11): 972.

Koornneef, M., Bentsink, L. y Hilhorst, H. (2002). Seed dormancy and germination. Curr Opin Plant Biol 5(1): 33 . 
Kotamraju, S., Tampo, Y., Keszler, A., Chitambar, C. R., Joseph, J., Haas, A. L. y Kalyanaraman, B. (2003). Nitric oxide inhibits $\mathrm{H} 2 \mathrm{O} 2$-induced transferrin receptor-dependent apoptosis in endothelial cells: Role of ubiquitin-proteasome pathway. Proc Natl Acad Sci U S A 100(19): 10653.

Krebs, E. y Fischer, E. (1964). PHOSPHORYLASE AND RELATED ENZYMES OF GLYCOGEN METABOLISM. Vitam Horm 22: 399.

Kumar, S. V. y Wigge, P. A. (2010). H2A.Z-containing nucleosomes mediate the thermosensory response in Arabidopsis. Cell 140(1): 136.

Kuo, W. N., Jn-Baptiste, J. B., Kanadia, R. N., McNabb, L. D., Zhai, L., Weeks, K., Dopson, N. y Chambers, M. C. (1996). Immunoreactivities of m-calpain, calpastatin, nitric oxide synthase, myelin basic protein and dynamin II in baker's yeast, wheat germ and lobster tail muscle. Cytobios 87(351): 251.

Kuo, W. N., Kanadia, R. N., Shanbhag, V. P. y Toro, R. (1999). Denitration of peroxynitrite-treated proteins by 'protein nitratases' from rat brain and heart. Mol Cell Biochem 201(1-2): 11.

Kuppusamy, K. T., Walcher, C. L. y Nemhauser, J. L. (2009). Cross-regulatory mechanisms in hormone signaling. Plant Mol Biol 69(4): 375.

Kuromori, T., Miyaji, T., Yabuuchi, H., Shimizu, H., Sugimoto, E., Kamiya, A., Moriyama, Y. y Shinozaki, K. (2010). ABC transporter AtABCG25 is involved in abscisic acid transport and responses. Proc Natl Acad Sci U S A 107(5): 2361.

Kuromori, T. y Shinozaki, K. (2010). ABA transport factors found in Arabidopsis ABC transporters. Plant Signal Behav 5(9): 1124.

Kushiro, T., Okamoto, M., Nakabayashi, K., Yamagishi, K., Kitamura, S., Asami, T., Hirai, N., Koshiba, T., Kamiya, Y. y Nambara, E. (2004). The Arabidopsis cytochrome P450 CYP707A encodes ABA 8'-hydroxylases: key enzymes in ABA catabolism. EMBO J 23(7): 1647.

Kwak, J. M., Mori, I. C., Pei, Z. M., Leonhardt, N., Torres, M. A., Dangl, J. L., Bloom, R. E., Bodde, S., Jones, J. D. y Schroeder, J. I. (2003). NADPH oxidase AtrbohD and AtrbohF genes function in ROSdependent ABA signaling in Arabidopsis. EMBO J 22(11): 2623.

Lamas, S., Marsden, P. A., Li, G. K., Tempst, P. y Michel, T. (1992). Endothelial nitric oxide synthase: molecular cloning and characterization of a distinct constitutive enzyme isoform. Proc Natl Acad Sci U S A 89(14): 6348.

Lamattina, L., Garcia-Mata, C., Graziano, M. y Pagnussat, G. (2003). Nitric oxide: the versatility of an extensive signal molecule. Annu Rev Plant Biol 54: 109.

Lamattina, L. y Polacco, J. C., Eds. (2007). Nitric Oxide in Plant Growth, Development and Stress Physiology. Plant Cell Monographs. Heidelberg, Springer-Verlag.

Laskowski, R. A., Rullmannn, J. A., MacArthur, M. W., Kaptein, R. y Thornton, J. M. (1996). AQUA and PROCHECK-NMR: programs for checking the quality of protein structures solved by NMR. J Biomol NMR 8(4): 477.

Lau, O. S. y Deng, X. W. (2010). Plant hormone signaling lightens up: integrators of light and hormones. Curr Opin Plant Biol 13(5): 571.

Layne, P. P. y Najjar, V. A. (1979). Evidence for a tyrosine residue at the active site of phosphoglucomutase and its interaction with vanadate. Proc Natl Acad Sci U S A 76(10): 5010.

Leckie, C. P., McAinsh, M. R., Allen, G. J., Sanders, D. y Hetherington, A. M. (1998). Abscisic acidinduced stomatal closure mediated by cyclic ADP-ribose. Proc Natl Acad Sci U S A 95(26): 15837. 
Lee, J., He, K., Stolc, V., Lee, H., Figueroa, P., Gao, Y., Tongprasit, W., Zhao, H., Lee, I. y Deng, X. W. (2007). Analysis of transcription factor HY5 genomic binding sites revealed its hierarchical role in light regulation of development. Plant Cell 19(3): 731.

Lee, K. H., Piao, H. L., Kim, H. Y., Choi, S. M., Jiang, F., Hartung, W., Hwang, I., Kwak, J. M. y Lee, I. J. (2006). Activation of glucosidase via stress-induced polymerization rapidly increases active pools of abscisic acid. Cell 126(6): 1109.

Lee, S., Cheng, H., King, K. E., Wang, W., He, Y., Hussain, A., Lo, J., Harberd, N. P. y Peng, J. (2002). Gibberellin regulates Arabidopsis seed germination via RGL2, a GAI/RGA-like gene whose expression is up-regulated following imbibition. Genes Dev 16(5): 646.

Lee, U., Wie, C., Fernandez, B. O., Feelisch, M. y Vierling, E. (2008). Modulation of nitrosative stress by S-nitrosoglutathione reductase is critical for thermotolerance and plant growth in Arabidopsis. Plant Cell 20(3): 786.

Legnaioli, T., Cuevas, J. y Mas, P. (2009). TOC1 functions as a molecular switch connecting the circadian clock with plant responses to drought. EMBO J 28(23): 3745.

Lei, S. Z., Pan, Z. H., Aggarwal, S. K., Chen, H. S., Hartman, J., Sucher, N. J. y Lipton, S. A. (1992).

Effect of nitric oxide production on the redox modulatory site of the NMDA receptor-channel complex.

Neuron 8(6): 1087.

Leitner, M., Vandelle, E., Gaupels, F., Bellin, D. y Delledonne, M. (2009). NO signals in the haze: nitric oxide signalling in plant defence. Curr Opin Plant Biol 12(4): 451.

Leivar, P., Monte, E., Al-Sady, B., Carle, C., Storer, A., Alonso, J. M., Ecker, J. R. y Quail, P. H. (2008a). The Arabidopsis phytochrome-interacting factor PIF7, together with PIF3 and PIF4, regulates responses to prolonged red light by modulating phyB levels. Plant Cell 20(2): 337.

Leivar, P., Monte, E., Oka, Y., Liu, T., Carle, C., Castillon, A., Huq, E. y Quail, P. H. (2008b). Multiple phytochrome-interacting bHLH transcription factors repress premature seedling photomorphogenesis in darkness. Curr Biol 18(23): 1815.

Leivar, P. y Quail, P. H. (2011). PIFs: pivotal components in a cellular signaling hub. Trends Plant Sci 16(1): 19 .

Leivar, P., Tepperman, J. M., Monte, E., Calderon, R. H., Liu, T. L. y Quail, P. H. (2009). Definition of early transcriptional circuitry involved in light-induced reversal of PIF-imposed repression of photomorphogenesis in young Arabidopsis seedlings. Plant Cell 21(11): 3535.

Li, B. y Foley, M. E. (1996). Transcriptional and Posttranscriptional Regulation of Dormancy-Associated Gene Expression by Afterripening in Wild Oat. Plant Physiol 110(4): 1267.

Li, H., Samouilov, A., Liu, X. y Zweier, J. L. (2001). Characterization of the magnitude and kinetics of xanthine oxidase-catalyzed nitrite reduction. Evaluation of its role in nitric oxide generation in anoxic tissues. J Biol Chem 276(27): 24482.

Li, L., Saga, N. y Mikami, K. (2009a). Ca2+ influx and phosphoinositide signalling are essential for the establishment and maintenance of cell polarity in monospores from the red alga Porphyra yezoensis. J Exp Bot 60(12): 3477.

Li, Y., Qi, J., Liu, K., Li, B., Wang, H. y Jia, J. (2010). Peroxynitrite-induced nitration of cyclooxygenase2 and inducible nitric oxide synthase promotes their binding in diabetic angiopathy. Mol Med 16(9-10): 335.

Li, Z., Wakao, S., Fischer, B. B. y Niyogi, K. K. (2009b). Sensing and responding to excess light. Annu Rev Plant Biol 60: 239.

Liang, F. S., Ho, W. Q. y Crabtree, G. R. (2011). Engineering the ABA Plant Stress Pathway for Regulation of Induced Proximity. Sci Signal 4(164): rs2. 
Libourel, I. G., Bethke, P. C., De Michele, R. y Jones, R. L. (2006). Nitric oxide gas stimulates germination of dormant Arabidopsis seeds: use of a flow-through apparatus for delivery of nitric oxide. Planta 223(4): 813.

Lillo, C., Meyer, C., Lea, U. S., Provan, F. y Oltedal, S. (2004). Mechanism and importance of posttranslational regulation of nitrate reductase. J Exp Bot 55(401): 1275.

Lin, C., Yang, H., Guo, H., Mockler, T., Chen, J. y Cashmore, A. R. (1998). Enhancement of blue-light sensitivity of Arabidopsis seedlings by a blue light receptor cryptochrome 2. Proc Natl Acad Sci U S A 95(5): 2686.

Lin, Y. y Cheng, C. L. (1997). A chlorate-resistant mutant defective in the regulation of nitrate reductase gene expression in Arabidopsis defines a new HY locus. Plant Cell 9(1): 21.

Lindermayr, C., Saalbach, G., Bahnweg, G. y Durner, J. (2006). Differential inhibition of Arabidopsis methionine adenosyltransferases by protein S-nitrosylation. J Biol Chem 281(7): 4285.

Lindermayr, C., Saalbach, G. y Durner, J. (2005). Proteomic identification of S-nitrosylated proteins in Arabidopsis. Plant Physiol 137(3): 921.

Lindermayr, C., Sell, S., Muller, B., Leister, D. y Durner, J. (2010). Redox regulation of the NPR1TGA1 system of Arabidopsis thaliana by nitric oxide. Plant Cell 22(8): 2894.

Liu, B., Tewari, A. K., Zhang, L., Green-Church, K. B., Zweier, J. L., Chen, Y. R. y He, G. (2009a). Proteomic analysis of protein tyrosine nitration after ischemia reperfusion injury: mitochondria as the major target. Biochim Biophys Acta 1794(3): 476.

Liu, C., Wang, J., Huang, T., Wang, F., Yuan, F., Cheng, X., Zhang, Y., Shi, S., Wu, J. y Liu, K. (2010). A missense mutation in the VHYNP motif of a DELLA protein causes a semi-dwarf mutant phenotype in Brassica napus. Theor Appl Genet 121(2): 249.

Liu, L., Hausladen, A., Zeng, M., Que, L., Heitman, J. y Stamler, J. S. (2001). A metabolic enzyme for S-nitrosothiol conserved from bacteria to humans. Nature 410(6827): 490.

Liu, X., Yue, Y., Li, B., Nie, Y., Li, W., Wu, W. H. y Ma, L. (2007). A G protein-coupled receptor is a plasma membrane receptor for the plant hormone abscisic acid. Science 315(5819): 1712.

Liu, Y., Shi, L., Ye, N., Liu, R., Jia, W. y Zhang, J. (2009b). Nitric oxide-induced rapid decrease of abscisic acid concentration is required in breaking seed dormancy in Arabidopsis. New Phytol 183(4): 1030.

Liu, Z., Cao, J., Ma, Q., Gao, X., Ren, J. y Xue, Y. (2011). GPS-YNO2: computational prediction of tyrosine nitration sites in proteins. Mol Biosyst 7(4): 1197.

Lo, S. C., Butt, Y. K. y Chan, Y. S. (2000). False nitric oxide synthase immunoreactivity in Asparagus bean (Vigna sesquipdalis). Nitric Oxide 4(2): 175.

Lombardo, M. C., Graziano, M., Polacco, J. C. y Lamattina, L. (2006). Nitric oxide functions as a positive regulator of root hair development. Plant Signal Behav 1(1): 28.

Lopez-Bucio, J., Acevedo-Hernandez, G., Ramirez-Chavez, E., Molina-Torres, J. y Herrera-Estrella, L. (2006). Novel signals for plant development. Curr Opin Plant Biol 9(5): 523.

Lorrain, S., Allen, T., Duek, P. D., Whitelam, G. C. y Fankhauser, C. (2008). Phytochrome-mediated inhibition of shade avoidance involves degradation of growth-promoting bHLH transcription factors. Plant J 53(2): 312.

Loy, J. B. y Liu, P. B. (1974). Response of seedlings of a dwarf and a normal strain of watermelon to gibberellins. Plant Physiol 53(3): 325. 
Lymar, S. V., Jiang, Q. y Hurst, J. K. (1996). Mechanism of carbon dioxide-catalyzed oxidation of tyrosine by peroxynitrite. Biochemistry 35(24): 7855.

Ma, Y., Szostkiewicz, I., Korte, A., Moes, D., Yang, Y., Christmann, A. y Grill, E. (2009). Regulators of PP2C phosphatase activity function as abscisic acid sensors. Science 324(5930): 1064.

MacRobbie, E. A. (2000). ABA activates multiple $\mathrm{Ca}(2+)$ fluxes in stomatal guard cells, triggering vacuolar $\mathrm{K}(+)(\mathrm{Rb}(+))$ release. Proc Natl Acad Sci U S A 97(22): 12361.

Mallick, N., Rai, L. C., Mohn, F. H. y Soeder, C. J. (1999). Studies on nitric oxide (NO) formation by the green alga Scenedesmus obliquus and the diazotrophic cyanobacterium Anabaena doliolum. Chemosphere 39(10): 1601.

Mallozzi, C., Ceccarini, M., Camerini, S., Macchia, G., Crescenzi, M., Petrucci, T. C. y Di Stasi, A. M. (2009). Peroxynitrite induces tyrosine residue modifications in synaptophysin C-terminal domain, affecting its interaction with src. J Neurochem 111(3): 859.

Mas, P., Devlin, P. F., Panda, S. y Kay, S. A. (2000). Functional interaction of phytochrome B and cryptochrome 2. Nature 408(6809): 207.

Mathews, S. (2006). Seeing the light. Nat Genet 38(6): 606.

McCourt, P. y Creelman, R. (2008). The ABA receptors -- we report you decide. Curr Opin Plant Biol 11(5): 474.

Melcher, K., Xu, Y., Ng, L. M., Zhou, X. E., Soon, F. F., Chinnusamy, V., Suino-Powell, K. M., Kovach, A., Tham, F. S., Cutler, S. R., Li, J., Yong, E. L., Zhu, J. K. y Xu, H. E. (2010). Identification and mechanism of ABA receptor antagonism. Nat Struct Mol Biol 17(9): 1102.

Melo, F. y Feytmans, E. (1998). Assessing protein structures with a non-local atomic interaction energy. J Mol Biol 277(5): 1141 .

Merlot, S., Gosti, F., Guerrier, D., Vavasseur, A. y Giraudat, J. (2001). The ABI1 and ABI2 protein phosphatases $2 \mathrm{C}$ act in a negative feedback regulatory loop of the abscisic acid signalling pathway. Plant $\mathbf{J}$ 25(3): 295.

Merlot, S., Mustilli, A. C., Genty, B., North, H., Lefebvre, V., Sotta, B., Vavasseur, A. y Giraudat, J. (2002). Use of infrared thermal imaging to isolate Arabidopsis mutants defective in stomatal regulation. Plant J 30(5): 601.

Miflin, B. J. (1974). The location of nitrite reductase and other enzymes related to amino Acid biosynthesis in the plastids of root and leaves. Plant Physiol 54(4): 550.

Mikula, I., Durocher, S., Martasek, P., Mutus, B. y Slama-Schwok, A. (2009). Isoform-specific differences in the nitrite reductase activity of nitric oxide synthases under hypoxia. Biochem J 418(3): 673.

Millar, T. M., Stevens, C. R., Benjamin, N., Eisenthal, R., Harrison, R. y Blake, D. R. (1998). Xanthine oxidoreductase catalyses the reduction of nitrates and nitrite to nitric oxide under hypoxic conditions. FEBS Lett 427(2): 225.

Millar, T. M., Stevens, C. R. y Blake, D. R. (1997). Xanthine oxidase can generate nitric oxide from nitrate in ischaemia. Biochem Soc Trans 25(3): 528S.

Mira-Rodado, V., Sweere, U., Grefen, C., Kunkel, T., Fejes, E., Nagy, F., Schafer, E. y Harter, K. (2007). Functional cross-talk between two-component and phytochrome B signal transduction in Arabidopsis. J Exp Bot 58(10): 2595.

Mishina, T. E., Lamb, C. y Zeier, J. (2007). Expression of a nitric oxide degrading enzyme induces a senescence programme in Arabidopsis. Plant Cell Environ 30(1): 39. 
Miyagi, M., Sakaguchi, H., Darrow, R. M., Yan, L., West, K. A., Aulak, K. S., Stuehr, D. J., Hollyfield, J. G., Organisciak, D. T. y Crabb, J. W. (2002). Evidence that light modulates protein nitration in rat retina. Mol Cell Proteomics 1(4): 293.

Modolo, L. V., Augusto, O., Almeida, I. M., Magalhaes, J. R. y Salgado, I. (2005). Nitrite as the major source of nitric oxide production by Arabidopsis thaliana in response to Pseudomonas syringae. FEBS Lett 579(17): 3814 .

Modolo, L. V., Cunha, F. Q., Braga, M. R. y Salgado, I. (2002). Nitric oxide synthase-mediated phytoalexin accumulation in soybean cotyledons in response to the Diaporthe phaseolorum $\mathrm{f}$. $\mathrm{sp}$. meridionalis elicitor. Plant Physiol 130(3): 1288.

Moglich, A., Yang, X., Ayers, R. A. y Moffat, K. (2010). Structure and function of plant photoreceptors. Annu Rev Plant Biol 61: 21.

Molassiotis, A., Tanou, G. y Diamantidis, G. (2010). NO says more than 'YES' to salt tolerance: Salt priming and systemic nitric oxide signaling in plants. Plant Signal Behav 5(3): 209.

Moreau, M., Lee, G. I., Wang, Y., Crane, B. R. y Klessig, D. F. (2008). AtNOS/AtNOA1 is a functional Arabidopsis thaliana cGTPase and not a nitric-oxide synthase. J Biol Chem 283(47): 32957.

Moreau, M., Lindermayr, C., Durner, J. y Klessig, D. F. (2010). NO synthesis and signaling in plants-where do we stand? Physiol Plant 138(4): 372.

Morot-Gaudry-Talarmain, Y., Rockel, P., Moureaux, T., Quillere, I., Leydecker, M. T., Kaiser, W. M. y Morot-Gaudry, J. F. (2002). Nitrite accumulation and nitric oxide emission in relation to cellular signaling in nitrite reductase antisense tobacco. Planta 215(5): 708.

Muangprom, A., Thomas, S. G., Sun, T. P. y Osborn, T. C. (2005). A novel dwarfing mutation in a green revolution gene from Brassica rapa. Plant Physiol 137(3): 931.

Muller, A. H. y Hansson, M. (2009). The barley magnesium chelatase 150-kd subunit is not an abscisic acid receptor. Plant Physiol 150(1): 157.

Muller, K., Carstens, A. C., Linkies, A., Torres, M. A. y Leubner-Metzger, G. (2009). The NADPHoxidase AtrbohB plays a role in Arabidopsis seed after-ripening. New Phytol 184(4): 885.

Mur, L. A., Carver, T. L. y Prats, E. (2006). NO way to live; the various roles of nitric oxide in plantpathogen interactions. J Exp Bot 57(3): 489.

Mur, L. A., Laarhoven, L. J., Harren, F. J., Hall, M. A. y Smith, A. R. (2008). Nitric oxide interacts with salicylate to regulate biphasic ethylene production during the hypersensitive response. Plant Physiol 148(3): 1537.

Murase, K., Hirano, Y., Sun, T. P. y Hakoshima, T. (2008). Gibberellin-induced DELLA recognition by the gibberellin receptor GID1. Nature 456(7221): 459.

Mussig, C., Shin, G. H. y Altmann, T. (2003). Brassinosteroids promote root growth in Arabidopsis. Plant Physiol 133(3): 1261.

Mustilli, A. C., Merlot, S., Vavasseur, A., Fenzi, F. y Giraudat, J. (2002). Arabidopsis OST1 protein kinase mediates the regulation of stomatal aperture by abscisic acid and acts upstream of reactive oxygen species production. Plant Cell 14(12): 3089.

Nakagawa, A., Sakamoto, S., Takahashi, M., Morikawa, H. y Sakamoto, A. (2007). The RNAi-mediated silencing of xanthine dehydrogenase impairs growth and fertility and accelerates leaf senescence in transgenic Arabidopsis plants. Plant Cell Physiol 48(10): 1484. 
Nakajima, M., Shimada, A., Takashi, Y., Kim, Y. C., Park, S. H., Ueguchi-Tanaka, M., Suzuki, H., Katoh, E., Iuchi, S., Kobayashi, M., Maeda, T., Matsuoka, M. y Yamaguchi, I. (2006). Identification and characterization of Arabidopsis gibberellin receptors. Plant J 46(5): 880.

Nambara, E. y Marion-Poll, A. (2005). Abscisic acid biosynthesis and catabolism. Annu Rev Plant Biol 56: 165 .

Navarro, L., Bari, R., Achard, P., Lison, P., Nemri, A., Harberd, N. P. y Jones, J. D. (2008). DELLAs control plant immune responses by modulating the balance of jasmonic acid and salicylic acid signaling. Curr Biol 18(9): 650.

Neff, M. M., Fankhauser, C. y Chory, J. (2000). Light: an indicator of time and place. Genes Dev 14(3): 257.

Neill, S. (2005). NO way to die--nitric oxide, programmed cell death and xylogenesis. New Phytol 165(1): 5 .

Neill, S., Barros, R., Bright, J., Desikan, R., Hancock, J., Harrison, J., Morris, P., Ribeiro, D. y Wilson, I. (2008). Nitric oxide, stomatal closure, and abiotic stress. J Exp Bot 59(2): 165.

Neill, S. J., Desikan, R., Clarke, A. y Hancock, J. T. (2002a). Nitric oxide is a novel component of abscisic acid signaling in stomatal guard cells. Plant Physiol 128(1): 13.

Neill, S. J., Desikan, R., Clarke, A., Hurst, R. D. y Hancock, J. T. (2002b). Hydrogen peroxide and nitric oxide as signalling molecules in plants. J Exp Bot 53(372): 1237.

Nelson, D. C., Lasswell, J., Rogg, L. E., Cohen, M. A. y Bartel, B. (2000). FKF1, a clock-controlled gene that regulates the transition to flowering in Arabidopsis. Cell 101(3): 331.

Nemhauser, J. (2008). Dawning of a new era: photomorphogenesis as an integrated molecular network. Curr Opin Plant Biol 11(1): 4.

Nemhauser, J. L., Maloof, J. N. y Chory, J. (2003). Building integrated models of plant growth and development. Plant Physiol 132(2): 436.

Neuhaus, G., Bowler, C., Hiratsuka, K., Yamagata, H. y Chua, N. H. (1997). Phytochrome-regulated repression of gene expression requires calcium and cGMP. EMBO J 16(10): 2554.

Ni, M., Tepperman, J. M. y Quail, P. H. (1998). PIF3, a phytochrome-interacting factor necessary for normal photoinduced signal transduction, is a novel basic helix-loop-helix protein. Cell 95(5): 657.

Nicolaou, A., Kenyon, S. H., Gibbons, J. M., Ast, T. y Gibbons, W. A. (1996). In vitro inactivation of mammalian methionine synthase by nitric oxide. Eur J Clin Invest 26(2): 167.

Nicolaou, A., Waterfield, C. J., Kenyon, S. H. y Gibbons, W. A. (1997). The inactivation of methionine synthase in isolated rat hepatocytes by sodium nitroprusside. Eur J Biochem 244(3): 876.

Nicotra, A. B., Atkin, O. K., Bonser, S. P., Davidson, A. M., Finnegan, E. J., Mathesius, U., Poot, P., Purugganan, M. D., Richards, C. L., Valladares, F. y van Kleunen, M. (2010). Plant phenotypic plasticity in a changing climate. Trends Plant Sci 15(12): 684.

Nishimura, N., Hitomi, K., Arvai, A. S., Rambo, R. P., Hitomi, C., Cutler, S. R., Schroeder, J. I. y Getzoff, E. D. (2009). Structural mechanism of abscisic acid binding and signaling by dimeric PYR1. Science 326(5958): 1373.

Nishimura, N., Sarkeshik, A., Nito, K., Park, S. Y., Wang, A., Carvalho, P. C., Lee, S., Caddell, D. F., Cutler, S. R., Chory, J., Yates, J. R. y Schroeder, J. I. (2010). PYR/PYL/RCAR family members are major in-vivo ABI1 protein phosphatase 2C-interacting proteins in Arabidopsis. Plant J 61(2): 290. 
Nitsan, J. y Lang, A. (1966). DNA synthesis in the elongating nondividing cells of the lentil epicotyl and its promotion by gibberellin. Plant Physiol 41(6): 965.

Nozue, K., Covington, M. F., Duek, P. D., Lorrain, S., Fankhauser, C., Harmer, S. L. y Maloof, J. N. (2007). Rhythmic growth explained by coincidence between internal and external cues. Nature 448(7151): 358.

Oh, E., Yamaguchi, S., Hu, J., Yusuke, J., Jung, B., Paik, I., Lee, H. S., Sun, T. P., Kamiya, Y. y Choi, G. (2007). PIL5, a phytochrome-interacting bHLH protein, regulates gibberellin responsiveness by binding directly to the GAI and RGA promoters in Arabidopsis seeds. Plant Cell 19(4): 1192.

Okamoto, M., Kushiro, T., Jikumaru, Y., Abrams, S. R., Kamiya, Y., Seki, M. y Nambara, E. (2011). ABA 9'-hydroxylation is catalyzed by CYP707A in Arabidopsis. Phytochemistry 72(8): 717.

Orozco-Cardenas, M. L. y Ryan, C. A. (2002). Nitric oxide negatively modulates wound signaling in tomato plants. Plant Physiol 130(1): 487.

Otvos, K., Pasternak, T. P., Miskolczi, P., Domoki, M., Dorjgotov, D., Szucs, A., Bottka, S., Dudits, D. y Feher, A. (2005). Nitric oxide is required for, and promotes auxin-mediated activation of, cell division and embryogenic cell formation but does not influence cell cycle progression in alfalfa cell cultures. Plant $\mathbf{J}$ 43(6): 849 .

Pagnussat, G. C., Lanteri, M. L. y Lamattina, L. (2003). Nitric oxide and cyclic GMP are messengers in the indole acetic acid-induced adventitious rooting process. Plant Physiol 132(3): 1241.

Pagnussat, G. C., Lanteri, M. L., Lombardo, M. C. y Lamattina, L. (2004). Nitric oxide mediates the indole acetic acid induction activation of a mitogen-activated protein kinase cascade involved in adventitious root development. Plant Physiol 135(1): 279.

Pagnussat, G. C., Simontacchi, M., Puntarulo, S. y Lamattina, L. (2002). Nitric oxide is required for root organogenesis. Plant Physiol 129(3): 954.

Palamalai, V. y Miyagi, M. (2010). Mechanism of glyceraldehyde-3-phosphate dehydrogenase inactivation by tyrosine nitration. Protein Sci 19(2): 255.

Palmieri, M. C., Lindermayr, C., Bauwe, H., Steinhauser, C. y Durner, J. (2010). Regulation of plant glycine decarboxylase by s-nitrosylation and glutathionylation. Plant Physiol 152(3): 1514.

Pandey, S., Nelson, D. C. y Assmann, S. M. (2009). Two novel GPCR-type G proteins are abscisic acid receptors in Arabidopsis. Cell 136(1): 136.

Parani, M., Rudrabhatla, S., Myers, R., Weirich, H., Smith, B., Leaman, D. W. y Goldman, S. L. (2004). Microarray analysis of nitric oxide responsive transcripts in Arabidopsis. Plant Biotechnol J 2(4): 359.

Parihar, M. S., Parihar, A., Chen, Z., Nazarewicz, R. y Ghafourifar, P. (2008). mAtNOS1 regulates mitochondrial functions and apoptosis of human neuroblastoma cells. Biochim Biophys Acta 1780(6): 921.

Park, E., Kim, J., Lee, Y., Shin, J., Oh, E., Chung, W. I., Liu, J. R. y Choi, G. (2004). Degradation of phytochrome interacting factor 3 in phytochrome-mediated light signaling. Plant Cell Physiol 45(8): 968.

Park, S. Y., Fung, P., Nishimura, N., Jensen, D. R., Fujii, H., Zhao, Y., Lumba, S., Santiago, J., Rodrigues, A., Chow, T. F., Alfred, S. E., Bonetta, D., Finkelstein, R., Provart, N. J., Desveaux, D., Rodriguez, P. L., McCourt, P., Zhu, J. K., Schroeder, J. I., Volkman, B. F. y Cutler, S. R. (2009). Abscisic acid inhibits type $2 \mathrm{C}$ protein phosphatases via the PYR/PYL family of START proteins. Science 324(5930): 1068.

Peng, J., Carol, P., Richards, D., King, K., Cowling, R., Murphy, G. y Harberd, N. (1997). The Arabidopsis GAI gene defines a signaling pathway that negatively regulates gibberellin responses. Genes Dev 11(23): 3194. 
Perazzolli, M., Romero-Puertas, M. C. y Delledonne, M. (2006). Modulation of nitric oxide bioactivity by plant haemoglobins. J Exp Bot 57(3): 479.

Petersen, B., Petersen, T. N., Andersen, P., Nielsen, M. y Lundegaard, C. (2009). A generic method for assignment of reliability scores applied to solvent accessibility predictions. BMC Struct Biol 9: 51.

Peterson, F. C., Burgie, E. S., Park, S. Y., Jensen, D. R., Weiner, J. J., Bingman, C. A., Chang, C. E., Cutler, S. R., Phillips, G. N., Jr. y Volkman, B. F. (2010). Structural basis for selective activation of ABA receptors. Nat Struct Mol Biol 17(9): 1109.

Phillips, A. L., Ward, D. A., Uknes, S., Appleford, N. E., Lange, T., Huttly, A. K., Gaskin, P., Graebe, J. E. y Hedden, P. (1995). Isolation and expression of three gibberellin 20-oxidase cDNA clones from Arabidopsis. Plant Physiol 108(3): 1049.

Planchet, E., Jagadis Gupta, K., Sonoda, M. y Kaiser, W. M. (2005). Nitric oxide emission from tobacco leaves and cell suspensions: rate limiting factors and evidence for the involvement of mitochondrial electron transport. Plant J 41(5): 732.

Planchet, E. y Kaiser, W. M. (2006). Nitric oxide (NO) detection by DAF fluorescence and chemiluminescence: a comparison using abiotic and biotic NO sources. J Exp Bot 57(12): 3043.

Pokorny, R., Klar, T., Hennecke, U., Carell, T., Batschauer, A. y Essen, L. O. (2008). Recognition and repair of UV lesions in loop structures of duplex DNA by DASH-type cryptochrome. Proc Natl Acad Sci U S A 105(52): 21023.

Polverari, A., Molesini, B., Pezzotti, M., Buonaurio, R., Marte, M. y Delledonne, M. (2003). Nitric oxide-mediated transcriptional changes in Arabidopsis thaliana. Mol Plant Microbe Interact 16(12): 1094.

Prado, A. M., Porterfield, D. M. y Feijo, J. A. (2004). Nitric oxide is involved in growth regulation and reorientation of pollen tubes. Development 131(11): 2707.

Qiao, W. y Fan, L. M. (2008). Nitric oxide signaling in plant responses to abiotic stresses. J Integr Plant Biol 50(10): 1238.

Radi, R. (2004). Nitric oxide, oxidants, and protein tyrosine nitration. Proc Natl Acad Sci U S A 101(12): 4003.

Ramirez, L., Zabaleta, E. J. y Lamattina, L. (2010). Nitric oxide and frataxin: two players contributing to maintain cellular iron homeostasis. Ann Bot 105(5): 801.

Razem, F. A., El-Kereamy, A., Abrams, S. R. y Hill, R. D. (2006). The RNA-binding protein FCA is an abscisic acid receptor. Nature 439(7074): 290.

Razem, F. A. y Hill, R. D. (2007). Hydrogen peroxide affects abscisic acid binding to ABAP1 in barley aleurones. Biochem Cell Biol 85(5): 628.

Reichler, S. A., Torres, J., Rivera, A. L., Cintolesi, V. A., Clark, G. y Roux, S. J. (2009). Intersection of two signalling pathways: extracellular nucleotides regulate pollen germination and pollen tube growth via nitric oxide. J Exp Bot 60(7): 2129.

Reynolds, J. D., Ahearn, G. S., Angelo, M., Zhang, J., Cobb, F. y Stamler, J. S. (2007). Snitrosohemoglobin deficiency: a mechanism for loss of physiological activity in banked blood. Proc Natl Acad Sci U S A 104(43): 17058.

Ribeiro, D. M., Desikan, R., Bright, J., Confraria, A., Harrison, J., Hancock, J. T., Barros, R. S., Neill, S. J. y Wilson, I. D. (2009). Differential requirement for NO during ABA-induced stomatal closure in turgid and wilted leaves. Plant Cell Environ 32(1): 46. 
Ribeiro, E. A., Jr., Cunha, F. Q., Tamashiro, W. M. y Martins, I. S. (1999). Growth phase-dependent subcellular localization of nitric oxide synthase in maize cells. FEBS Lett 445(2-3): 283.

Richards, D. E., King, K. E., Ait-Ali, T. y Harberd, N. P. (2001). HOW GIBBERELLIN REGULATES PLANT GROWTH AND DEVELOPMENT: A Molecular Genetic Analysis of Gibberellin Signaling. Annu Rev Plant Physiol Plant Mol Biol 52: 67.

Richter, R., Behringer, C., Muller, I. K. y Schwechheimer, C. (2010). The GATA-type transcription factors GNC and GNL/CGA1 repress gibberellin signaling downstream from DELLA proteins and PHYTOCHROME-INTERACTING FACTORS. Genes Dev 24(18): 2093.

Rieu, I., Eriksson, S., Powers, S. J., Gong, F., Griffiths, J., Woolley, L., Benlloch, R., Nilsson, O., Thomas, S. G., Hedden, P. y Phillips, A. L. (2008). Genetic analysis reveals that C19-GA 2-oxidation is a major gibberellin inactivation pathway in Arabidopsis. Plant Cell 20(9): 2420.

Risk, J. M., Macknight, R. C. y Day, C. L. (2008). FCA does not bind abscisic acid. Nature 456(7223): E5.

Rizzini, L., Favory, J. J., Cloix, C., Faggionato, D., O'Hara, A., Kaiserli, E., Baumeister, R., Schafer, E., Nagy, F., Jenkins, G. I. y UIm, R. (2011). Perception of UV-B by the Arabidopsis UVR8 protein. Science 332(6025): 103 .

Rockel, P., Strube, F., Rockel, A., Wildt, J. y Kaiser, W. M. (2002). Regulation of nitric oxide (NO) production by plant nitrate reductase in vivo and in vitro. J Exp Bot 53(366): 103.

Roelfsema, M. R. y Hedrich, R. (2005). In the light of stomatal opening: new insights into 'the Watergate'. New Phytol 167(3): 665.

Roelfsema, M. R. y Hedrich, R. (2010). Making sense out of $\mathrm{Ca}(2+)$ signals: their role in regulating stomatal movements. Plant Cell Environ 33(3): 305.

Romanov, G. A., Lomin, S. N., Rakova, N. Y., Heyl, A. y Schmulling, T. (2008). Does NO play a role in cytokinin signal transduction? FEBS Lett 582(6): 874.

Romera, F. J., Garcia, M. J., Alcantara, E. y Perez-Vicente, R. (2011). Latest findings about the interplay of auxin, ethylene and nitric oxide in the regulation of Fe deficiency responses by Strategy I plants. Plant Signal Behav 6(1).

Romero-Puertas, M. C., Campostrini, N., Matte, A., Righetti, P. G., Perazzolli, M., Zolla, L., Roepstorff, P. y Delledonne, M. (2008). Proteomic analysis of S-nitrosylated proteins in Arabidopsis thaliana undergoing hypersensitive response. Proteomics 8(7): 1459.

Romero-Puertas, M. C., Laxa, M., Matte, A., Zaninotto, F., Finkemeier, I., Jones, A. M., Perazzolli, M., Vandelle, E., Dietz, K. J. y Delledonne, M. (2007). S-nitrosylation of peroxiredoxin II E promotes peroxynitrite-mediated tyrosine nitration. Plant Cell 19(12): 4120.

Romero-Puertas, M. C., Perazzolli, M., Zago, E. D. y Delledonne, M. (2004). Nitric oxide signalling functions in plant-pathogen interactions. Cell Microbiol 6(9): 795.

Rubio, S., Rodrigues, A., Saez, A., Dizon, M. B., Galle, A., Kim, T. H., Santiago, J., Flexas, J., Schroeder, J. I. y Rodriguez, P. L. (2009). Triple loss of function of protein phosphatases type 2C leads to partial constitutive response to endogenous abscisic acid. Plant Physiol 150(3): 1345.

Rusterucci, C., Espunya, M. C., Diaz, M., Chabannes, M. y Martinez, M. C. (2007). Snitrosoglutathione reductase affords protection against pathogens in Arabidopsis, both locally and systemically. Plant Physiol 143(3): 1282.

Ryan, S. A., Nelson, R. S. y Harper, J. E. (1983). Soybean Mutants Lacking Constitutive Nitrate Reductase Activity : II. Nitrogen Assimilation, Chlorate Resistance, and Inheritance. Plant Physiol 72(2): 510 . 
Saez, A., Apostolova, N., Gonzalez-Guzman, M., Gonzalez-Garcia, M. P., Nicolas, C., Lorenzo, O. y Rodriguez, P. L. (2004). Gain-of-function and loss-of-function phenotypes of the protein phosphatase 2C $\mathrm{HAB} 1$ reveal its role as a negative regulator of abscisic acid signalling. Plant J 37(3): 354.

Saez, A., Robert, N., Maktabi, M. H., Schroeder, J. I., Serrano, R. y Rodriguez, P. L. (2006). Enhancement of abscisic acid sensitivity and reduction of water consumption in Arabidopsis by combined inactivation of the protein phosphatases type 2C ABI1 and HAB1. Plant Physiol 141(4): 1389.

Saijo, Y., Sullivan, J. A., Wang, H., Yang, J., Shen, Y., Rubio, V., Ma, L., Hoecker, U. y Deng, X. W. (2003). The COP1-SPA1 interaction defines a critical step in phytochrome A-mediated regulation of HY5 activity. Genes Dev 17(21): 2642.

Saito, S., Hirai, N., Matsumoto, C., Ohigashi, H., Ohta, D., Sakata, K. y Mizutani, M. (2004). Arabidopsis CYP707As encode (+)-abscisic acid 8'-hydroxylase, a key enzyme in the oxidative catabolism of abscisic acid. Plant Physiol 134(4): 1439.

Saito, S., Yamamoto-Katou, A., Yoshioka, H., Doke, N. y Kawakita, K. (2006). Peroxynitrite generation and tyrosine nitration in defense responses in tobacco BY-2 cells. Plant Cell Physiol 47(6): 689.

Sakamoto, A., Sakurao, S. H., Fukunaga, K., Matsubara, T., Ueda-Hashimoto, M., Tsukamoto, S., Takahashi, M. y Morikawa, H. (2004). Three distinct Arabidopsis hemoglobins exhibit peroxidase-like activity and differentially mediate nitrite-dependent protein nitration. FEBS Lett 572(1-3): 27.

Sakihama, Y., Nakamura, S. y Yamasaki, H. (2002). Nitric oxide production mediated by nitrate reductase in the green alga Chlamydomonas reinhardtii: an alternative NO production pathway in photosynthetic organisms. Plant Cell Physiol 43(3): 290.

Sandalio, L. M., Rodriguez-Serrano, M., Romero-Puertas, M. C. y Del Rio, L. A. (2008). Imaging of reactive oxygen species and nitric oxide in vivo in plant tissues. Methods Enzymol 440: 397.

Santiago, J., Dupeux, F., Round, A., Antoni, R., Park, S. Y., Jamin, M., Cutler, S. R., Rodriguez, P. L. y Marquez, J. A. (2009). The abscisic acid receptor PYR1 in complex with abscisic acid. Nature 462(7273): 665 .

Santner, A., Calderon-Villalobos, L. I. y Estelle, M. (2009). Plant hormones are versatile chemical regulators of plant growth. Nat Chem Biol 5(5): 301.

Sarath, G., Bethke, P. C., Jones, R., Baird, L. M., Hou, G. y Mitchell, R. B. (2006). Nitric oxide accelerates seed germination in warm-season grasses. Planta 223(6): 1154.

Sarver, A., Scheffler, N. K., Shetlar, M. D. y Gibson, B. W. (2001). Analysis of peptides and proteins containing nitrotyrosine by matrix-assisted laser desorption/ionization mass spectrometry. J Am Soc Mass Spectrom 12(4): 439.

Sasaki, A., Itoh, H., Gomi, K., Ueguchi-Tanaka, M., Ishiyama, K., Kobayashi, M., Jeong, D. H., An, G., Kitano, H., Ashikari, M. y Matsuoka, M. (2003). Accumulation of phosphorylated repressor for gibberellin signaling in an F-box mutant. Science 299(5614): 1896.

Schmidt, P., Youhnovski, N., Daiber, A., Balan, A., Arsic, M., Bachschmid, M., Przybylski, M. y Ullrich, V. (2003). Specific nitration at tyrosine 430 revealed by high resolution mass spectrometry as basis for redox regulation of bovine prostacyclin synthase. J Biol Chem 278(15): 12813.

Schomburg, F. M., Bizzell, C. M., Lee, D. J., Zeevaart, J. A. y Amasino, R. M. (2003). Overexpression of a novel class of gibberellin 2-oxidases decreases gibberellin levels and creates dwarf plants. Plant Cell 15(1): 151 .

Schopfer, F. J., Baker, P. R. y Freeman, B. A. (2003). NO-dependent protein nitration: a cell signaling event or an oxidative inflammatory response? Trends Biochem Sci 28(12): 646. 
Schroeder, J. I. y Nambara, E. (2006). A quick release mechanism for abscisic acid. Cell 126(6): 1023.

Schultz, T. F., Kiyosue, T., Yanovsky, M., Wada, M. y Kay, S. A. (2001). A role for LKP2 in the circadian clock of Arabidopsis. Plant Cell 13(12): 2659.

Selby, C. P. y Sancar, A. (2006). A cryptochrome/photolyase class of enzymes with single-stranded DNAspecific photolyase activity. Proc Natl Acad Sci U S A 103(47): 17696.

Seligman, K., Saviani, E. E., Oliveira, H. C., Pinto-Maglio, C. A. y Salgado, I. (2008). Floral transition and nitric oxide emission during flower development in Arabidopsis thaliana is affected in nitrate reductasedeficient plants. Plant Cell Physiol 49(7): 1112.

Sen, S. y Cheema, I. R. (1995). Nitric oxide synthase and calmodulin immunoreactivity in plant embryonic tissue. Biochem. Arch. 11: 221.

Seo, H. S., Watanabe, E., Tokutomi, S., Nagatani, A. y Chua, N. H. (2004). Photoreceptor ubiquitination by COP1 E3 ligase desensitizes phytochrome A signaling. Genes Dev 18(6): 617.

Seo, H. S., Yang, J. Y., Ishikawa, M., Bolle, C., Ballesteros, M. L. y Chua, N. H. (2003). LAF1

ubiquitination by COP1 controls photomorphogenesis and is stimulated by SPA1. Nature 423(6943): 995.

Serpa, V., Vernal, J., Lamattina, L., Grotewold, E., Cassia, R. y Terenzi, H. (2007). Inhibition of AtMYB2 DNA-binding by nitric oxide involves cysteine S-nitrosylation. Biochem Biophys Res Commun 361(4): 1048.

Shang, Y., Yan, L., Liu, Z. Q., Cao, Z., Mei, C., Xin, Q., Wu, F. Q., Wang, X. F., Du, S. Y., Jiang, T., Zhang, X. F., Zhao, R., Sun, H. L., Liu, R., Yu, Y. T. y Zhang, D. P. (2010). The Mg-chelatase H subunit of Arabidopsis antagonizes a group of WRKY transcription repressors to relieve ABA-responsive genes of inhibition. Plant Cell 22(6): 1909.

Sharov, V. S., Galeva, N. A., Dremina, E. S., Williams, T. D. y Schoneich, C. (2009). Inactivation of rabbit muscle glycogen phosphorylase $b$ by peroxynitrite revisited: does the nitration of Tyr613 in the allosteric inhibition site control enzymatic function? Arch Biochem Biophys 484(2): 155.

Shen, H., Moon, J. y Huq, E. (2005). PIF1 is regulated by light-mediated degradation through the ubiquitin-26S proteasome pathway to optimize photomorphogenesis of seedlings in Arabidopsis. Plant $\mathbf{J}$ 44(6): 1023.

Shen, Y., Khanna, R., Carle, C. M. y Quail, P. H. (2007). Phytochrome induces rapid PIF5 phosphorylation and degradation in response to red-light activation. Plant Physiol 145(3): 1043.

Shen, Y. Y., Wang, X. F., Wu, F. Q., Du, S. Y., Cao, Z., Shang, Y., Wang, X. L., Peng, C. C., Yu, X. C., Zhu, S. Y., Fan, R. C., Xu, Y. H. y Zhang, D. P. (2006). The Mg-chelatase H subunit is an abscisic acid receptor. Nature 443(7113): 823.

Shin, J., Park, E. y Choi, G. (2007). PIF3 regulates anthocyanin biosynthesis in an HY5-dependent manner with both factors directly binding anthocyanin biosynthetic gene promoters in Arabidopsis. Plant J 49(6): 981.

Shkolnik-Inbar, D. y Bar-Zvi, D. (2010). ABI4 mediates abscisic acid and cytokinin inhibition of lateral root formation by reducing polar auxin transport in Arabidopsis. Plant Cell 22(11): 3560.

Silverstone, A. L., Ciampaglio, C. N. y Sun, T. (1998). The Arabidopsis RGA gene encodes a transcriptional regulator repressing the gibberellin signal transduction pathway. Plant Cell 10(2): 155.

Silverstone, A. L., Jung, H. S., Dill, A., Kawaide, H., Kamiya, Y. y Sun, T. P. (2001). Repressing a repressor: gibberellin-induced rapid reduction of the RGA protein in Arabidopsis. Plant Cell 13(7): 1555.

Silverstone, A. L., Tseng, T. S., Swain, S. M., Dill, A., Jeong, S. Y., Olszewski, N. E. y Sun, T. P. (2007). Functional analysis of SPINDLY in gibberellin signaling in Arabidopsis. Plant Physiol 143(2): 987. 
Sirichandra, C., Wasilewska, A., Vlad, F., Valon, C. y Leung, J. (2009). The guard cell as a single-cell model towards understanding drought tolerance and abscisic acid action. J Exp Bot 60(5): 1439.

Skirycz, A., Claeys, H., De Bodt, S., Oikawa, A., Shinoda, S., Andriankaja, M., Maleux, K., Eloy, N. B., Coppens, F., Yoo, S. D., Saito, K. y Inze, D. (2011a). Pause-and-Stop: The Effects of Osmotic Stress on Cell Proliferation during Early Leaf Development in Arabidopsis and a Role for Ethylene Signaling in Cell Cycle Arrest. Plant Cell.

Skirycz, A., Vandenbroucke, K., Clauw, P., Maleux, K., De Meyer, B., Dhondt, S., Pucci, A., Gonzalez, N., Hoeberichts, F., Tognetti, V. B., Galbiati, M., Tonelli, C., Van Breusegem, F., Vuylsteke, M. y Inze, D. (2011b). Survival and growth of Arabidopsis plants given limited water are not equal. Nat Biotechnol 29(3): 212 .

Soderling, A. S., Hultman, L., Delbro, D., Hojrup, P. y Caidahl, K. (2007). Reduction of the nitro group during sample preparation may cause underestimation of the nitration level in 3-nitrotyrosine immunoblotting. J Chromatogr B Analyt Technol Biomed Life Sci 851(1-2): 277.

Somers, D. E., Schultz, T. F., Milnamow, M. y Kay, S. A. (2000). ZEITLUPE encodes a novel clockassociated PAS protein from Arabidopsis. Cell 101(3): 319.

Souza, J. M., Choi, I., Chen, Q., Weisse, M., Daikhin, E., Yudkoff, M., Obin, M., Ara, J., Horwitz, J. y Ischiropoulos, H. (2000). Proteolytic degradation of tyrosine nitrated proteins. Arch Biochem Biophys 380(2): 360 .

Souza, J. M., Daikhin, E., Yudkoff, M., Raman, C. S. y Ischiropoulos, H. (1999). Factors determining the selectivity of protein tyrosine nitration. Arch Biochem Biophys 371(2): 169.

Stamler, J. S., Jaraki, O., Osborne, J., Simon, D. I., Keaney, J., Vita, J., Singel, D., Valeri, C. R. y Loscalzo, J. (1992a). Nitric oxide circulates in mammalian plasma primarily as an S-nitroso adduct of serum albumin. Proc Natl Acad Sci U S A 89(16): 7674.

Stamler, J. S., Lamas, S. y Fang, F. C. (2001). Nitrosylation. the prototypic redox-based signaling mechanism. Cell 106(6): 675.

Stamler, J. S., Simon, D. I., Osborne, J. A., Mullins, M. E., Jaraki, O., Michel, T., Singel, D. J. y Loscalzo, J. (1992b). S-nitrosylation of proteins with nitric oxide: synthesis and characterization of biologically active compounds. Proc Natl Acad Sci U S A 89(1): 444.

Stamler, J. S., Singel, D. J. y Loscalzo, J. (1992c). Biochemistry of nitric oxide and its redox-activated forms. Science 258(5090): 1898.

Stamler, J. S., Toone, E. J., Lipton, S. A. y Sucher, N. J. (1997). (S)NO signals: translocation, regulation, and a consensus motif. Neuron 18(5): 691 .

Stasolla, C., Katahira, R., Thorpe, T. A. y Ashihara, H. (2003). Purine and pyrimidine nucleotide metabolism in higher plants. J Plant Physiol 160(11): 1271.

Stavang, J. A., Gallego-Bartolome, J., Gomez, M. D., Yoshida, S., Asami, T., Olsen, J. E., GarciaMartinez, J. L., Alabadi, D. y Blazquez, M. A. (2009). Hormonal regulation of temperature-induced growth in Arabidopsis. Plant J 60(4): 589.

Steen, H. y Mann, M. (2004). The ABC's (and XYZ's) of peptide sequencing. Nat Rev Mol Cell Biol 5(9): 699.

Stevens, S. M., Jr., Prokai-Tatrai, K. y Prokai, L. (2008). Factors that contribute to the misidentification of tyrosine nitration by shotgun proteomics. Mol Cell Proteomics 7(12): 2442.

Stirpe, F. y Della Corte, E. (1969). The regulation of rat liver xanthine oxidase. Conversion in vitro of the enzyme activity from dehydrogenase (type D) to oxidase (type O). J Biol Chem 244(14): 3855. 
Stohr, C., Strube, F., Marx, G., Ullrich, W. R. y Rockel, P. (2001). A plasma membrane-bound enzyme of tobacco roots catalyses the formation of nitric oxide from nitrite. Planta 212(5-6): 835.

Strittmatter, P., Soll, J. y Bolter, B. (2010). The chloroplast protein import machinery: a review. Methods Mol Biol 619: 307.

Stuehr, D. J. (1997). Structure-function aspects in the nitric oxide synthases. Annu Rev Pharmacol Toxicol 37: 339.

Sultana, R., Poon, H. F., Cai, J., Pierce, W. M., Merchant, M., Klein, J. B., Markesbery, W. R. y Butterfield, D. A. (2006). Identification of nitrated proteins in Alzheimer's disease brain using a redox proteomics approach. Neurobiol Dis 22(1): 76.

Sun, J., Xin, C., Eu, J. P., Stamler, J. S. y Meissner, G. (2001). Cysteine-3635 is responsible for skeletal muscle ryanodine receptor modulation by NO. Proc Natl Acad Sci U S A 98(20): 11158.

Sun, T. P. y Gubler, F. (2004). Molecular mechanism of gibberellin signaling in plants. Annu Rev Plant Biol 55: 197.

Suzuki, H., Park, S. H., Okubo, K., Kitamura, J., Ueguchi-Tanaka, M., Iuchi, S., Katoh, E., Kobayashi, M., Yamaguchi, I., Matsuoka, M., Asami, T. y Nakajima, M. (2009). Differential expression and affinities of Arabidopsis gibberellin receptors can explain variation in phenotypes of multiple knock-out mutants. Plant J 60(1): 48.

Suzuki, Y., Tanaka, M., Sohmiya, M., Ichinose, S., Omori, A. y Okamoto, K. (2005). Identification of nitrated proteins in the normal rat brain using a proteomics approach. Neurol Res 27(6): 630.

Tada, Y., Mori, T., Shinogi, T., Yao, N., Takahashi, S., Betsuyaku, S., Sakamoto, M., Park, P., Nakayashiki, H., Tosa, Y. y Mayama, S. (2004). Nitric oxide and reactive oxygen species do not elicit hypersensitive cell death but induce apoptosis in the adjacent cells during the defense response of oat. Mol Plant Microbe Interact 17(3): 245.

Tada, Y., Spoel, S. H., Pajerowska-Mukhtar, K., Mou, Z., Song, J., Wang, C., Zuo, J. y Dong, X. (2008). Plant immunity requires conformational changes [corrected] of NPR1 via S-nitrosylation and thioredoxins. Science 321(5891): 952.

Takaya, N. (2002). Dissimilatory nitrate reduction metabolisms and their control in fungi. J Biosci Bioeng 94(6): 506.

Tayeh, M. A. y Marletta, M. A. (1989). Macrophage oxidation of L-arginine to nitric oxide, nitrite, and nitrate. Tetrahydrobiopterin is required as a cofactor. J Biol Chem 264(33): 19654.

Thomas, S. G., Phillips, A. L. y Hedden, P. (1999). Molecular cloning and functional expression of gibberellin 2- oxidases, multifunctional enzymes involved in gibberellin deactivation. Proc Natl Acad Sci U S A 96(8): 4698.

Tischner, R., Galli, M., Heimer, Y. M., Bielefeld, S., Okamoto, M., Mack, A. y Crawford, N. M. (2007). Interference with the citrulline-based nitric oxide synthase assay by argininosuccinate lyase activity in Arabidopsis extracts. FEBS J 274(16): 4238.

Toledo-Ortiz, G., Huq, E. y Quail, P. H. (2003). The Arabidopsis basic/helix-loop-helix transcription factor family. Plant Cell 15(8): 1749.

Tonon, C., Cecilia Terrile, M., Jose Iglesias, M., Lamattina, L. y Casalongue, C. (2010). Extracellular ATP, nitric oxide and superoxide act coordinately to regulate hypocotyl growth in etiolated Arabidopsis seedlings. J Plant Physiol 167(7): 540.

Tornieri, K. y Rehder, V. (2007). Nitric oxide release from a single cell affects filopodial motility on growth cones of neighboring neurons. Dev Neurobiol 67(14): 1932. 
Trewavas, A. (2009). What is plant behaviour? Plant Cell Environ 32(6): 606.

Trimm, K. R. y Rehder, V. (2004). Nitric oxide acts as a slow-down and search signal in developing neurites. Eur J Neurosci 19(4): 809.

Tsai, Y. C., Delk, N. A., Chowdhury, N. I. y Braam, J. (2007). Arabidopsis potential calcium sensors regulate nitric oxide levels and the transition to flowering. Plant Signal Behav 2(6): 446.

Tsukagoshi, H., Busch, W. y Benfey, P. N. (2010). Transcriptional regulation of ROS controls transition from proliferation to differentiation in the root. Cell 143(4): 606.

Tsumoto, H., Taguchi, R. y Kohda, K. (2010). Efficient identification and quantification of peptides containing nitrotyrosine by matrix-assisted laser desorption/ionization time-of-flight mass spectrometry after derivatization. Chem Pharm Bull (Tokyo) 58(4): 488.

Tun, N. N., Holk, A. y Scherer, G. F. (2001). Rapid increase of NO release in plant cell cultures induced by cytokinin. FEBS Lett 509(2): 174.

Tun, N. N., Livaja, M., Kieber, J. J. y Scherer, G. F. (2008). Zeatin-induced nitric oxide (NO) biosynthesis in Arabidopsis thaliana mutants of NO biosynthesis and of two-component signaling genes. New Phytol 178(3): 515.

Tun, N. N., Santa-Catarina, C., Begum, T., Silveira, V., Handro, W., Floh, E. I. y Scherer, G. F. (2006). Polyamines induce rapid biosynthesis of nitric oxide (NO) in Arabidopsis thaliana seedlings. Plant Cell Physiol 47(3): 346.

Turko, I. V., Li, L., Aulak, K. S., Stuehr, D. J., Chang, J. Y. y Murad, F. (2003). Protein tyrosine nitration in the mitochondria from diabetic mouse heart. Implications to dysfunctional mitochondria in diabetes. J Biol Chem 278(36): 33972.

Tziomalos, K. y Hare, J. M. (2009). Role of xanthine oxidoreductase in cardiac nitroso-redox imbalance. Front Biosci 14: 237.

Ubeda-Tomas, S., Federici, F., Casimiro, I., Beemster, G. T., Bhalerao, R., Swarup, R., Doerner, P., Haseloff, J. y Bennett, M. J. (2009). Gibberellin signaling in the endodermis controls Arabidopsis root meristem size. Curr Biol 19(14): 1194.

Ubeda-Tomas, S., Swarup, R., Coates, J., Swarup, K., Laplaze, L., Beemster, G. T., Hedden, P., Bhalerao, R. y Bennett, M. J. (2008). Root growth in Arabidopsis requires gibberellin/DELLA signalling in the endodermis. Nat Cell Biol 10(5): 625.

Ueguchi-Tanaka, M., Ashikari, M., Nakajima, M., Itoh, H., Katoh, E., Kobayashi, M., Chow, T. Y., Hsing, Y. I., Kitano, H., Yamaguchi, I. y Matsuoka, M. (2005). GIBBERELLIN INSENSITIVE DWARF1 encodes a soluble receptor for gibberellin. Nature 437(7059): 693.

Ueguchi-Tanaka, M., Nakajima, M., Katoh, E., Ohmiya, H., Asano, K., Saji, S., Hongyu, X., Ashikari, M., Kitano, H., Yamaguchi, I. y Matsuoka, M. (2007). Molecular interactions of a soluble gibberellin receptor, GID1, with a rice DELLA protein, SLR1, and gibberellin. Plant Cell 19(7): 2140.

Valderrama, R., Corpas, F. J., Carreras, A., Fernandez-Ocana, A., Chaki, M., Luque, F., GomezRodriguez, M. V., Colmenero-Varea, P., Del Rio, L. A. y Barroso, J. B. (2007). Nitrosative stress in plants. FEBS Lett 581(3): 453.

van der Vliet, A., Eiserich, J. P., Halliwell, B. y Cross, C. E. (1997). Formation of reactive nitrogen species during peroxidase-catalyzed oxidation of nitrite. A potential additional mechanism of nitric oxidedependent toxicity. J Biol Chem 272(12): 7617.

Varbanova, M., Yamaguchi, S., Yang, Y., McKelvey, K., Hanada, A., Borochov, R., Yu, F., Jikumaru, Y., Ross, J., Cortes, D., Ma, C. J., Noel, J. P., Mander, L., Shulaev, V., Kamiya, Y., Rodermel, S., 
Weiss, D. y Pichersky, E. (2007). Methylation of gibberellins by Arabidopsis GAMT1 and GAMT2. Plant Cell 19(1): 32.

Vardi, A., Bidle, K. D., Kwityn, C., Hirsh, D. J., Thompson, S. M., Callow, J. A., Falkowski, P. y Bowler, C. (2008). A diatom gene regulating nitric-oxide signaling and susceptibility to diatom-derived aldehydes. Curr Biol 18(12): 895.

Wang, F., Zhu, D., Huang, X., Li, S., Gong, Y., Yao, Q., Fu, X., Fan, L. M. y Deng, X. W. (2009a). Biochemical insights on degradation of Arabidopsis DELLA proteins gained from a cell-free assay system. Plant Cell 21(8): 2378.

Wang, Y. Q., Feechan, A., Yun, B. W., Shafiei, R., Hofmann, A., Taylor, P., Xue, P., Yang, F. Q., Xie, Z. S., Pallas, J. A., Chu, C. C. y Loake, G. J. (2009b). S-nitrosylation of AtSABP3 antagonizes the expression of plant immunity. J Biol Chem 284(4): 2131.

Webb, A. A., Larman, M. G., Montgomery, L. T., Taylor, J. E. y Hetherington, A. M. (2001). The role of calcium in ABA-induced gene expression and stomatal movements. Plant $\mathbf{J}$ 26(3): 351.

Weiner, J. J., Peterson, F. C., Volkman, B. F. y Cutler, S. R. (2010). Structural and functional insights into core ABA signaling. Curr Opin Plant Biol 13(5): 495.

Wendehenne, D., Durner, J. y Klessig, D. F. (2004). Nitric oxide: a new player in plant signalling and defence responses. Curr Opin Plant Biol 7(4): 449.

Wilkinson, J. Q. y Crawford, N. M. (1991). Identification of the Arabidopsis CHL3 gene as the nitrate reductase structural gene NIA2. Plant Cell 3(5): 461.

Wilkinson, J. Q. y Crawford, N. M. (1993). Identification and characterization of a chlorate-resistant mutant of Arabidopsis thaliana with mutations in both nitrate reductase structural genes NIA1 and NIA2. Mol Gen Genet 239(1-2): 289.

Willige, B. C., Ghosh, S., Nill, C., Zourelidou, M., Dohmann, E. M., Maier, A. y Schwechheimer, C. (2007). The DELLA domain of GA INSENSITIVE mediates the interaction with the GA INSENSITIVE DWARF1A gibberellin receptor of Arabidopsis. Plant Cell 19(4): 1209.

Woodward, A. W. y Bartel, B. (2005). Auxin: regulation, action, and interaction. Ann Bot 95(5): 707.

Wu, F. Q., Xin, Q., Cao, Z., Liu, Z. Q., Du, S. Y., Mei, C., Zhao, C. X., Wang, X. F., Shang, Y., Jiang, T., Zhang, X. F., Yan, L., Zhao, R., Cui, Z. N., Liu, R., Sun, H. L., Yang, X. L., Su, Z. y Zhang, D. P. (2009). The magnesium-chelatase $H$ subunit binds abscisic acid and functions in abscisic acid signaling: new evidence in Arabidopsis. Plant Physiol 150(4): 1940.

Wu, W., Chen, Y. y Hazen, S. L. (1999). Eosinophil peroxidase nitrates protein tyrosyl residues. Implications for oxidative damage by nitrating intermediates in eosinophilic inflammatory disorders. $\mathbf{J}$ Biol Chem 274(36): 25933.

Xie, X. y Yoneyama, K. (2010). The strigolactone story. Annu Rev Phytopathol 48: 93.

Xu, J., Wang, S., Wu, Y., Song, P. y Zou, M. H. (2009). Tyrosine nitration of PA700 activates the 26S proteasome to induce endothelial dysfunction in mice with angiotensin II-induced hypertension. Hypertension 54(3): 625.

Xu, M. J., Dong, J. F. y Zhu, M. Y. (2005). Nitric oxide mediates the fungal elicitor-induced hypericin production of Hypericum perforatum cell suspension cultures through a jasmonic-acid-dependent signal pathway. Plant Physiol 139(2): 991.

Yakovlev, V. A., Bayden, A. S., Graves, P. R., Kellogg, G. E. y Mikkelsen, R. B. (2010). Nitration of the tumor suppressor protein p53 at tyrosine 327 promotes p53 oligomerization and activation. Biochemistry 49(25): 5331. 
Yamada, R. X., Matsuki, N. y Ikegaya, Y. (2006). Nitric oxide/cyclic guanosine monophosphate-mediated growth cone collapse of dentate granule cells. Neuroreport 17(6): 661.

Yamaguchi-Shinozaki, K. y Shinozaki, K. (1993). Arabidopsis DNA encoding two desiccation-responsive rd29 genes. Plant Physiol 101(3): 1119.

Yamaguchi, S. (2008). Gibberellin metabolism and its regulation. Annu Rev Plant Biol 59: 225.

Yamamoto-Katou, A., Katou, S., Yoshioka, H., Doke, N. y Kawakita, K. (2006). Nitrate reductase is responsible for elicitin-induced nitric oxide production in Nicotiana benthamiana. Plant Cell Physiol 47(6): 726.

Yamasaki, H. (2000). Nitrite-dependent nitric oxide production pathway: implications for involvement of active nitrogen species in photoinhibition in vivo. Philos Trans R Soc Lond B Biol Sci 355(1402): 1477.

Yamasaki, H. y Sakihama, Y. (2000). Simultaneous production of nitric oxide and peroxynitrite by plant nitrate reductase: in vitro evidence for the NR-dependent formation of active nitrogen species. FEBS Lett 468(1): 89 .

Yamasaki, H., Sakihama, Y. y Takahashi, S. (1999). An alternative pathway for nitric oxide production in plants: new features of an old enzyme. Trends Plant Sci 4(4): 128.

Yamashino, T., Matsushika, A., Fujimori, T., Sato, S., Kato, T., Tabata, S. y Mizuno, T. (2003). A Link between circadian-controlled bHLH factors and the APRR1/TOC1 quintet in Arabidopsis thaliana. Plant Cell Physiol 44(6): 619.

Ye, Z., Rodriguez, R., Tran, A., Hoang, H., de los Santos, D., Brown, S. y Vellanoweth, R. L. (2000) The developmental transition to flowering represses ascorbate peroxidase activity and induces enzymatic lipid peroxidation in leaf tissue in Arabidopsis thaliana. Plant Sci 158(1-2): 115.

Zaragoza, R., Torres, L., Garcia, C., Eroles, P., Corrales, F., Bosch, A., Lluch, A., Garcia-Trevijano, E. R. y Vina, J. R. (2009). Nitration of cathepsin D enhances its proteolytic activity during mammary gland remodelling after lactation. Biochem J 419(2): 279.

Zeidler, D., Zahringer, U., Gerber, I., Dubery, I., Hartung, T., Bors, W., Hutzler, P. y Durner, J. (2004). Innate immunity in Arabidopsis thaliana: lipopolysaccharides activate nitric oxide synthase (NOS) and induce defense genes. Proc Natl Acad Sci U S A 101(44): 15811.

Zeier, J., Delledonne, M., Mishina, T., Severi, E., Sonoda, M. y Lamb, C. (2004). Genetic elucidation of nitric oxide signaling in incompatible plant-pathogen interactions. Plant Physiol 136(1): 2875.

Zemojtel, T., Frohlich, A., Palmieri, M. C., Kolanczyk, M., Mikula, I., Wyrwicz, L. S., Wanker, E. E., Mundlos, S., Vingron, M., Martasek, P. y Durner, J. (2006a). Plant nitric oxide synthase: a never-ending story? Trends Plant Sci 11(11): 524.

Zemojtel, T., Kolanczyk, M., Kossler, N., Stricker, S., Lurz, R., Mikula, I., Duchniewicz, M., Schuelke, M., Ghafourifar, P., Martasek, P., Vingron, M. y Mundlos, S. (2006b). Mammalian mitochondrial nitric oxide synthase: characterization of a novel candidate. FEBS Lett 580(2): 455.

Zhan, X. y Desiderio, D. M. (2009). Mass spectrometric identification of in vivo nitrotyrosine sites in the human pituitary tumor proteome. Methods Mol Biol 566: 137.

Zhang, A., Jiang, M., Zhang, J., Ding, H., Xu, S., Hu, X. y Tan, M. (2007a). Nitric oxide induced by hydrogen peroxide mediates abscisic acid-induced activation of the mitogen-activated protein kinase cascade involved in antioxidant defense in maize leaves. New Phytol 175(1): 36.

Zhang, A., Zhang, J., Ye, N., Zhang, H., Tan, M. y Jiang, M. (2011). Nitric oxide mediates brassinosteroid-induced ABA biosynthesis involved in oxidative stress tolerance in maize leaves. Plant Cell Physiol 52(1): 181. 
Zhang, H., Han, W., De Smet, I., Talboys, P., Loya, R., Hassan, A., Rong, H., Jurgens, G., Paul Knox, J. y Wang, M. H. (2010). ABA promotes quiescence of the quiescent centre and suppresses stem cell differentiation in the Arabidopsis primary root meristem. Plant J 64(5): 764.

Zhang, L., Wang, Y., Zhao, L. y Shi, S. (2006). Involvement of nitric oxide in light-mediated greening of barley seedlings. J Plant Physiol 163(8): 818.

Zhang, M., An, L., Feng, H., Chen, T., Chen, K., Liu, Y., Tang, H., Chang, J. y Wang, X. (2003). The cascade mechanisms of nitric oxide as a second messenger of ultraviolet B in inhibiting mesocotyl elongations. Photochem Photobiol 77(2): 219.

Zhang, Q., Qian, W. J., Knyushko, T. V., Clauss, T. R., Purvine, S. O., Moore, R. J., Sacksteder, C. A., Chin, M. H., Smith, D. J., Camp, D. G., 2nd, Bigelow, D. J. y Smith, R. D. (2007b). A method for selective enrichment and analysis of nitrotyrosine-containing peptides in complex proteome samples. J Proteome Res 6(6): 2257.

Zhang, X., Zhang, L., Dong, F., Gao, J., Galbraith, D. W. y Song, C. P. (2001). Hydrogen peroxide is involved in abscisic acid-induced stomatal closure in Vicia faba. Plant Physiol 126(4): 1438.

Zhang, Z., Naughton, D., Winyard, P. G., Benjamin, N., Blake, D. R. y Symons, M. C. (1998). Generation of nitric oxide by a nitrite reductase activity of xanthine oxidase: a potential pathway for nitric oxide formation in the absence of nitric oxide synthase activity. Biochem Biophys Res Commun 249(3): 767.

Zhang, Z., Naughton, D. P., Blake, D. R., Benjamin, N., Stevens, C. R., Winyard, P. G., Symons, M. C. y Harrison, R. (1997). Human xanthine oxidase converts nitrite ions into nitric oxide (NO). Biochem Soc Trans 25(3): 524S

Zhao, D. Y., Tian, Q. Y., Li, L. H. y Zhang, W. H. (2007). Nitric oxide is involved in nitrate-induced inhibition of root elongation in Zea mays. Ann Bot 100(3): 497.

Zhou, J., Li, H., Zeng, J. y Huang, K. (2009). Effects of peroxynitrite-induced protein tyrosine nitration on insulin-stimulated tyrosine phosphorylation in HepG2 cells. Mol Cell Biochem 331(1-2): 49.

Zhu, Y., Nomura, T., Xu, Y., Zhang, Y., Peng, Y., Mao, B., Hanada, A., Zhou, H., Wang, R., Li, P., Zhu, X., Mander, L. N., Kamiya, Y., Yamaguchi, S. y He, Z. (2006). ELONGATED UPPERMOST INTERNODE encodes a cytochrome P450 monooxygenase that epoxidizes gibberellins in a novel deactivation reaction in rice. Plant Cell 18(2): 442.

Zhu, Y., Tepperman, J. M., Fairchild, C. D. y Quail, P. H. (2000). Phytochrome B binds with greater apparent affinity than phytochrome A to the basic helix-loop-helix factor PIF3 in a reaction requiring the PAS domain of PIF3. Proc Natl Acad Sci U S A 97(24): 13419.

Zisapel, N. (1978). The reactivity of a functional tyrosyl residue in carboxypeptidase B. Nitration of the cadmium enzyme. Eur J Biochem 90(1): 199.

Zottini, M., Costa, A., De Michele, R., Ruzzene, M., Carimi, F. y Lo Schiavo, F. (2007). Salicylic acid activates nitric oxide synthesis in Arabidopsis. J Exp Bot 58(6): 1397.

Zrenner, R., Stitt, M., Sonnewald, U. y Boldt, R. (2006). Pyrimidine and purine biosynthesis and degradation in plants. Annu Rev Plant Biol 57: 805. 

ANEXO: Publicaciones derivadas de la Tesis doctoral 